\title{
Filmes semicondutores amorfos à base de Si
}

\author{
Prof. Antonio Ricardo Zanatta \\ Laboratório de Filmes Finos - LFF \\ Instituto de Física de São Carlos - IFSC \\ Universidade de São Paulo - USP
}





\section{Índice}

\section{Capítulo 1}

\section{Semicondutores à base de Si: Conquistas \& Desafios}

Introdução

State of the art

pg 01

Tendências

Referências pg 04

\section{Capítulo 2}

\section{Estudo dos mecanismos de cristalização em semicondutores amorfos}

Introdução

Motivação

pg 05

Conceitos fundamentais

Estados (de agrupamento) da matéria pg 06

Estrutura atômica e eletrônica pg 08

Formação de filmes finos pg 11

Estabilidade térmica e estrutural pg 14

Cristalização

Cristalização induzida por espécies metálicas (MIC) pg 15

Cristalização induzida por radiação laser (LIC) pg 17 Resultados experimentais na área de Cristalização de filmes finos

Cristalização induzida por espécies metálicas MIC

Parte 1 - O sistema Ge-Al pg 21

Parte 2 - O sistema Si-Ni pg 25

Parte 3 - Outros sistemas pg 30

Cristalização induzida por radiação laser (LIC)

Parte 1 - Cristalização homogênea pg 32

Parte 2 - Cristalização seletiva ou laser structuring pg 34

Parte 3 - Aplicações de cristalização seletiva ou laser structuring pg 35 Considerações finais pg 38 Referências pg 40 


\section{Capítulo 3}

Propriedades ópticas-eletrônicas de filmes finos dopados com íons terra-rara

Introdução

Motivação

$\operatorname{pg} 43$

Conceitos fundamentais

Os íons terra-rara

pg 46

$\mathrm{O}$ sistema semicondutor+RE ${ }^{3+}$

pg 49

Resultados experimentais na área de Filmes finos dopados com íons terra-rara

Parte 1 - Filmes de silício amorfo hidrogenado (a-Si:H) pg 52

Parte 2 - Filmes de silício amorfo nitrogenado (a-SiN) pg 58

Parte 3 - Outros materiais

3.A - Filmes de a-GaAsN pg 70

3.B - Filmes de a-AIN pg 72

3.C - Filmes de a-GeN pg 78

3.D - Filmes de a-BeN e a-ZnO pg 81

Considerações finais pg 83

Referências pg 85

\section{Capítulo 4}

Filmes semicondutores à base de Si: Conclusões \& Perspectivas

Conclusões \& Perspectivas pg 89 


\section{Capítulo 1}

\section{Semicondutores à base de Si Conquistas \& Desafios}

\section{Introdução}

\section{State of the art}

A influência exercida por equipamentos eletrônicos sobre a sociedade humana não é um fenômeno recente e pode-se dizer que teve início com a invenção do primeiro transistor, no final da década de 1940 [1,2]. Nos dias atuais, estes dispositivos à base de materiais semicondutores não apenas fazem parte do nosso cotidiano, como tornaram-se simplesmente essenciais. Exemplos da sua aplicação podem ser encontrados em praticamente todas as partes, desempenhando as mais diferentes funções: no trabalho (basicamente associados a recursos de controle, comunicação, manipulação e/ou registro de informações), no conforto dos nossos lares (sob a forma de equipamentos eletro-eletrônicos diversos), nos momentos de lazer (dispositivos de áudio e vídeo), etc.

Sob o ponto de vista técnico-científico, muitos dos avanços da atual indústria (micro-)eletrônica só foram possíveis graças ao altíssimo grau de desenvolvimento e sofisticação conquistados, tendo 0 silício e seus compostos como principais protagonistas. 
Um exemplo clássico que ilustra a influência da tecnologia do silício sobre a indústria (micro-)eletrônica diz respeito à evolução experimentada pelos recursos de informática - com destaque especial para a complexidade e capacidade de integração-miniaturização de seus componentes individuais.

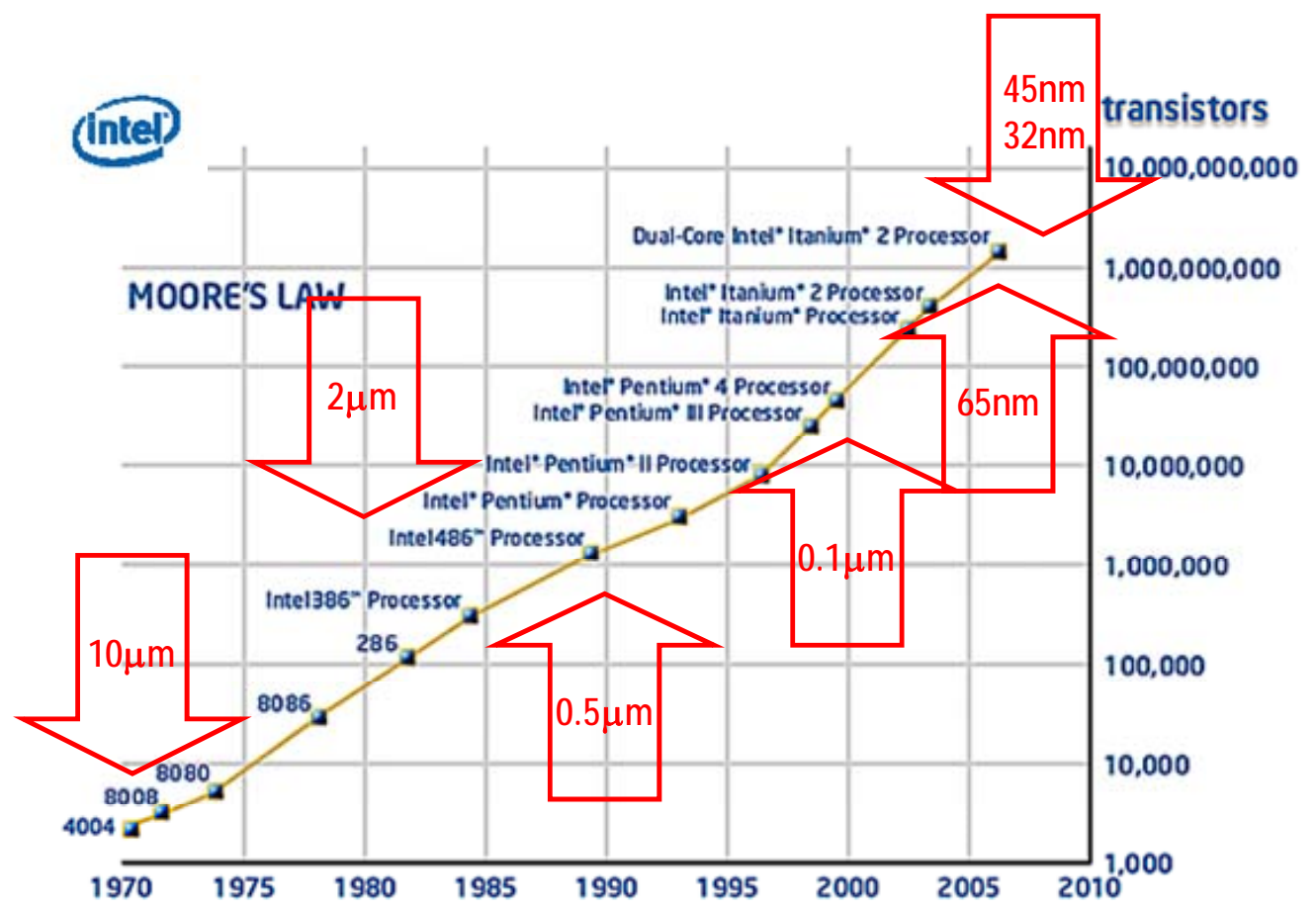

Figura 1 - Evolução do número de transistores contidos em um chip de computador entre 1970 e 2005. A esta evolução no número de transistores ao longo dos anos (levando-se em conta, também, aspectos econômicos), dá-se o nome de lei de Moore. A fim de ilustrar o desenvolvimento tecnológico associado, as dimensões típicas dos transistores de filme fino (constituintes essenciais de alguns chips) estão indicadas. Fonte: http://www.intel.com/technology/architecture-silicon/silicon.htm?iid=tech as Ihn+silicon.

Por cerca de mais de 40 anos, os avanços na área de informática vêm obedecendo à lei de Moore (Figura 1) - a qual prevê que o "número de transistores contidos em um chip (ou micro-circuito eletrônico integrado capaz de desempenhar vários comandos ou funções simultaneamente) deve dobrar a cada dois anos" [3]. Ao longo deste período, a tecnologia do silício tem se demonstrado totalmente adaptada para promover 0 aumento da densidade de transistores (miniaturização) bem como a implementação de novas arquiteturas de microprocessadores. Apesar de desenvolvida e eficiente, a tecnologia dos dispositivos eletrônicos tendo por base 0 silício está chegando ao seu limite - especialmente se levarmos em consideração questões como: rapidez, eficiência, e consumo energético, dentre outras. Mais especificamente, estima-se que dispositivos baseados na tecnologia do silício possam responder pela demanda tecnológica dos próximos 10 (ou no máximo 15) anos. Desta forma, a continuidade da lei de Moore (e consequente implemento das capacidades de informática) requer inovações não apenas nas dimensões mas, principalmente, nos materiais e estrutura dos chips. 


\section{Tendências}

Tendo em vista o cenário acima descrito, o foco de muitas das atuais pesquisas em Ciências de Materiais tem sido: (1) a busca por substitutos ao silício (e seus compostos) e, (2) o desenvolvimento de novas metodologias de processamento aplicáveis à indústria (micro-)eletrônica.

No primeiro caso, vários são os candidatos que apresentam características de eficiência e miniaturização (e, portanto, portabilidade e baixo consumo energético) comparáveis ou, até mesmo, superiores àquelas exibidas pelo silício. Em sua grande maioria, no entanto, os custos associados são inviáveis e/ou a tecnologia necessária é ainda incipiente. No segundo caso, questões de caráter econômico indicam que o sucesso no desenvolvimento-aplicação de novas metodologias de processamento depende, necessariamente, do grau de compatibilidade com a já estabelecida tecnologia do silício. Uma terceira e última alternativa, consiste no estudo-desenvolvimento de novas propriedades para o silício e seus compostos e vem recebendo denominações específicas, dependendo das características exploradas: fotônica do silício (envolvendo a combinação de propriedades ópticas e eletrônicas) [4,5], spintrônica do silício (combinando propriedades magnéticas e eletrônicas) [6,7], etc. Em outras palavras, enquanto a atual indústria (micro-)eletrônica praticamente se confunde com a ciência e tecnologia do silício e seus compostos, tudo leva a crer que, a sua efetiva utilização em dispositivos híbridos (fotônicos ou spintrônicos) está sujeita ao estudo sistemático de suas propriedades sob diferentes condições.

Após estas poucas palavras acerca da importância do silício na indústria (micro-)eletrônica, os capítulos seguintes tratam de trabalhos realizados no Laboratório de Filmes Finos (LFF- IFSC) sob o tema de Filmes Semicondutores Amorfos à base de Silício. Mais especificamente, no Capítulo 2 são apresentados e discutidos resultados associados aos mecanismos de cristalização de filmes semicondutores amorfos - uma área de grande interesse acadêmico e potencial aplicação na moderna indústria (micro-)eletrônica. Já no Capítulo 3 , são considerados aspectos relativos às propriedades ópticas-eletrônicas de filmes finos quando dopados com espécies opticamente ativas ou, mais apropriadamente, da fotônica do silício. Por fim, o Capítulo 4 resgata alguns conceitos e principais resultados apresentados ao longo deste documento, bem como propõe idéias para a realização de trabalhos futuros. 


\section{Referências}

1 J. Orton, in The Story of Semiconductors (Oxford University Press, Oxford 2009).

2 Muito embora seja comum associar aos pesquisadores John Bardeen, Walter Brattain e William Shockley da AT\&T Bell Labs (EUA) a "descoberta" do transistor, em 1947, a sua história data de muito antes. Não há qualquer dúvida quanto à contribuição de Bardeen, Brattain e Shockley no desenvolvimento das funcionalidades daquilo que hoje chamamos de transistor. Outras contribuições, no entanto, foram decisivas para 0 seu sucesso: Julius E. Lilienfeld (com uma patente canadense de 1925 sobre um protótipo similar ao atual transistor de filme fino); Herbert Mataré (em 1942, com os seus duo-diodos ou transistores de ponto de contato); e Gordon Teal (que, efetivamente, confeccionou o primeiro transistor à base de silício, em 1954, na Texas Instruments). O primeiro transistor utilizando a tecnologia MOS (metal oxide semiconductor) foi produzido na AT\&T Bell Labs apenas em 1960. Fonte, website: http://en.wikipedia.org/wiki/Transistor.

${ }^{3}$ G.E. Moore, Electronics 38 (1965).

4 Vários autores, Materials Today 8 (2005).

5 Website: http://techresearch.intel.com/ResearchAreaDetails.aspx?ld=26

${ }^{6}$ I. Zutic, J. Fabian, and S. Das Sarma, Rev. Mod. Phys. 76, 323 (2004).

${ }^{7}$ Website: http://www.physicsweb.org/bestof/cond-mat 


\section{Capítulo 2}

\section{Estudo dos mecanismos de cristalização em semicondutores amorfos}

\section{Introdução \\ Motivação}

$\mathrm{Na}$ área de materiais semicondutores existe, ainda hoje, uma certa preferência pelo estudo-desenvolvimento de compostos com estrutura atômica cristalina. Em parte, isto deve-se à possibilidade de investigações teóricas e, principalmente, pelo potencial tecnológico que esta classe de materiais representa. Ainda que relativamente complexos quanto à simulação-previsão de muitas das suas propriedades, os materiais semicondutores de estrutura atômica amorfa são igualmente interessantes para muitas aplicações. Caracterizam-se, ainda, por: (1) envolverem técnicas de preparo comparativamente mais simples e economicamente convenientes, e (2) sob a forma de filmes finos, serem perfeitamente adaptáveis para a produção de grandes áreas - uma característica extremamente importante para a confecção de células solares, displays, e detectores de radiação, por exemplo. Além disto, como consequência direta da sua estrutura desordenada, permitem: (3) explorar materiais com praticamente qualquer composição, e (4) induzir-controlar a sua cristalização. Estes dois últimos aspectos são particularmente interessantes no desenvolvimento de materiais com propriedades inéditas e serão considerados nas páginas que se seguem. 


\section{Conceitos Fundamentais}

\section{Estados (de agrupamento) da matéria}

Sob o ponto de vista macroscópico, todas as substâncias podem existir em (pelo menos) três diferentes estados: como gases, líquidos ou sólidos. Estes três estados da matéria são qualitativamente distintos com respeito ao grau de interação de suas unidades fundamentais (átomos e moléculas) e, consequentemente, com relação às suas estruturas atômicas e propriedades [1].

Gases são identificados, geralmente, por apresentarem baixa densidade e uma movimentação de partículas (sobre distâncias que, muitas vezes, excedem seus tamanhos típicos) relativamente independente de suas características atômicas. Em primeira aproximação, o volume livre de um gás é igual ao volume ocupado pelo sistema. Neste estado, as partículas podem ser tratadas como meras coordenadas matemáticas (gás perfeito). Em análises mais realistas, no entanto, deve-se levar em consideração a dimensão, a forma, e a interação entre as partículas individuais. Gases são sistemas compressíveis que obedecem à lei de BoyleMariotte $\left(\mathrm{V} \propto \mathrm{P}^{-1}\right)$.

Líquidos, por sua vez, possuem uma densidade maior que os gases e um volume livre consideravelmente menor. Como resultado, não se aplica o conceito de translação independente de suas partículas. 0 movimento de espécies em sistemas líquidos possui um caráter cooperativo e a interação entre as partículas determina muitas das propriedades do sistema. Além disto, a compressibilidade é muito menor que no caso dos gases e, em muitos casos, sistemas líquidos são praticamente incompressíveis. De acordo com o modelo de Frenkel [2], o movimento de partículas em um líquido pode ser considerado como uma "oscilação" ao redor de posições médias que alteram suas coordenadas após um determinado tempo. Segundo o modelo, a distância média entre dois "centros de oscilação" subsequentes é comparável à dimensão das partículas que compõem 0 líquido. Ainda que o modelo de Frenkel seja bastante limitado, ele ilustra a existência de ordem local e a mobilidade das partículas - pré-requisitos para o caráter viscoso e ausência de forma nos líquidos.

Sólidos são considerados, tradicionalmente, como cristais ou como uma estrutura tri-dimensional formada a partir da repetição periódica de uma determinada configuração de partículas ou de uma unidade elementar. Em outras palavras, além de ordem local (também presente nos líquidos) os sólidos exibem ordem de longo alcance ou invariância translacional. Dentro deste contexto podemos encontrar vários tipos de sólidos e suas respectivas definições [3]: sólido (material cuja viscosidade exceda $\sim 10^{14} \mathrm{~N} \mathrm{~s} \mathrm{~m}^{-2}$ ), material amorfo (os quais não possuem periodicidade estrita, ou ordem translacional de longo alcance), vidro (estrutura desordenada que apresenta uma temperatura de transição bem marcada), poli-cristal (arranjo de unidades cristalinas com diferentes orientações), micro- ou nano-cristal (sistemas contendo cristais com dimensões micro- ou nanoscópicas, imersos em uma matriz amorfa), etc. Em todos os casos, a definição baseia-se em alguma característica do sistema e, como tal, está sujeita a limitações.

Ainda sob o aspecto físico-morfológico, podemos identificar o estado de uma substância (ou sistema) levando em consideração algumas das suas características termodinâmicas. Se o estado é representado pela energia livre $G$, esta pode ser associada à temperatura $T$ mediante a seguinte expressão:

$$
G=H-T S
$$

onde a entalpia $H$ indica a energia interna, e a entropia $S$ o grau de desordem do sistema. Os estados termodinamicamente estável ou meta-estável correspondem à condição de $G$ em mínimos de energia. No entanto, vale salientar que, ao contrário de um cristal (ou quasi-cristal), líquidos e gases, a condição termodinâmica de 
um vidro (ou sólido amorfo) é descrita como um estado de não-equilíbrio, isto é, a energia livre $G$ não se encontra em um valor de mínimo energético (Tabela 1).

Tabela 1 - Diferentes estados da matéria e suas respectivas condições termodinâmicas.

\begin{tabular}{|c|c|}
\hline Estado & Estado Termodinâmico \\
\hline sólido (cristal) & estável \\
\hline quasi-cristal & meta-estável \\
\hline vidro (ou amorfo) & não-equilíbrio \\
\hline líquido & estável \\
\hline líquido super-resfriado & meta-estável \\
\hline gás & estável \\
\hline
\end{tabular}

A fim ilustrar a discussão, consideremos o caso de um vidro - um típico material amorfo. Na Figura 1(a), o volume específico de algumas substâncias em diferentes estados é representado em função da temperatura [3]. Se a substância, inicialmente sob a forma líquida, é resfriada lentamente, ela se solidifica à temperatura $T_{m}$ dando origem a um sólido de estrutura cristalina (sequência $1 \rightarrow 2 \rightarrow 3 \rightarrow 4$ ). Esta é uma transição de fase onde há liberação de energia (reação exotérmica). Tal processo é reversível, de forma que, se uma substância sólida é aquecida, ela se funde à temperatura $T_{m}$ para se transformar em líquido. Neste caso, deve-se fornecer energia ao sistema (reação endotérmica) e $T_{m}$ indica o ponto de fusão (ou melting), que é característico do material. Em outras palavras, enquanto o estado sólido representa uma situação estável, com a energia livre do sistema minimizada na faixa de temperatura abaixo de $T_{m}$, a situação estável de temperaturas acima de $T_{m}$ é 0 estado líquido. Isto significa que, na Eq. (1), o valor de energia livre $G$ do sistema é minimizado quando se reduz a entalpia $H$ em $T<T_{m}$, e também quando se aumenta a entropia (ou desordem) em $T>T_{m}$. Uma representação artística para as energias livres envolvidas no processo está indicada na Figura 1(b).

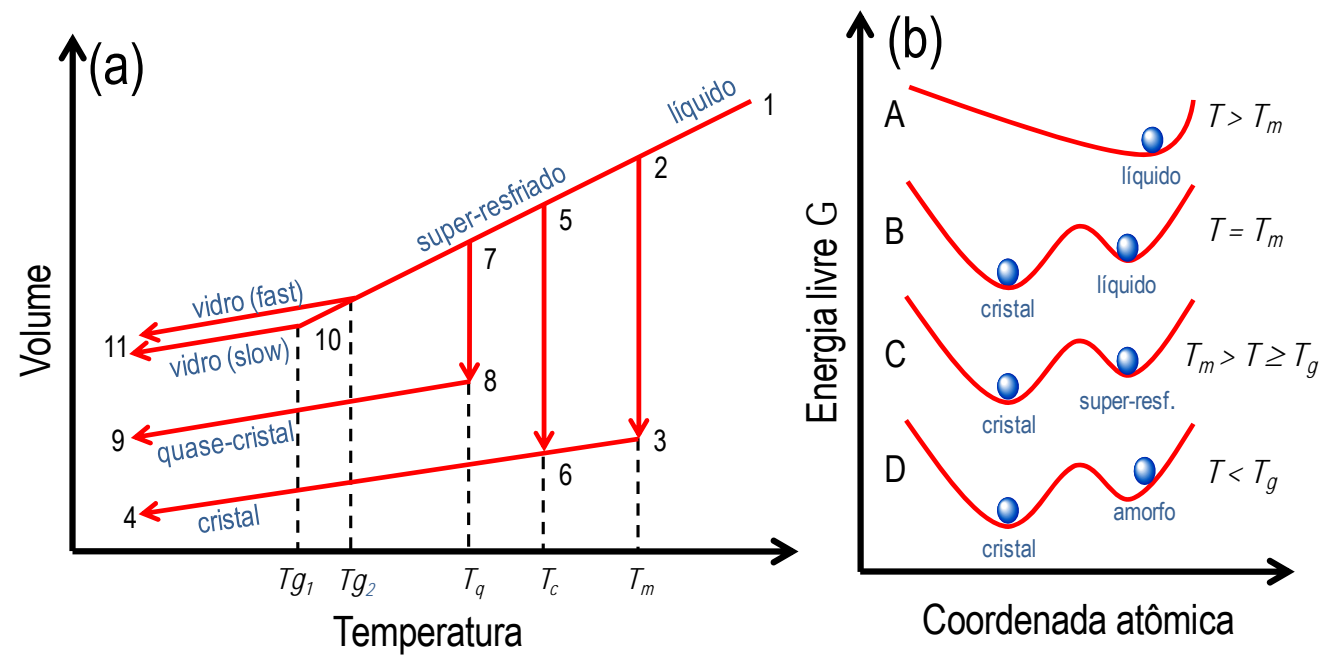

Figura 1 - (a) Representação esquemática do volume ocupado por um sistema em função da temperatura. Segundo esta representação, a taxa de resfriamento de uma substância (inicialmente no estado líquido 1) pode dar origem a sólidos com estrutura atômica: perfeitamente ordenada (cristal: $1 \rightarrow 2 \rightarrow 3 \rightarrow 4$ ou $1 \rightarrow 5 \rightarrow 6 \rightarrow 4$ ), parcialmente ordenada (quase-cristal: $1 \rightarrow 7 \rightarrow 8 \rightarrow 9$ ), ou desordenada (vidro: $1 \rightarrow 10 \rightarrow 11$ ). (b) Análogo mecânico da energia livre $G$ para as configurações: $A-$ líquido, B- líquido-sólido em $T=T_{m}, C$ - líquido super-resfriado, e D- vidro ou material amorfo. 
Se o mesmo líquido é submetido a uma taxa de resfriamento maior (indicada por "super-resfriado" na Fig. 1), a transformação líquido $\rightarrow$ sólido pode ocorrer em $T_{c}, T_{q}$ ou $T_{g}$. $O$ estado "super-resfriado" (2-5-7-10) deve-se à viscosidade inerente do sistema líquido, e a sua eventual transformação resulta em sistemas com diferentes estruturas atômicas e, consequentemente, propriedades. Conforme indicado na Fig. 1, 0 resfriamento de um sistema líquido pode resultar em sólidos ordenados (cristal) às temperaturas $T_{m}$ (melting temperature) e $T_{c}$ (crystallization temperature), enquanto, taxas de resfriamento ainda maiores levam a estados desordenados do tipo quase-cristal ( $T_{q}$ - quasi-crystal temperature) e vidro ( $T_{g}-$ glass transition temperature). Sob a forma "super-resfriada" a substância apresenta estrutura semelhante à de um líquido com sua rotação molecular e difusão atômica "congeladas" na temperatura $T_{g}$. Se a taxa de resfriamento é extremamente alta, pode-se "congelar" a estrutura atômica do sistema a temperaturas relativamente maiores $\left(T_{g 1} \rightarrow T_{g 2}\right.$, por exemplo). Dentro deste contexto fica claro porque sólidos amorfos podem apresentar diferentes estruturas desordenadas e são associados a estados de não-equilíbrio [situação D na Fig. 1(b)]. Em resumo, do ponto de vista energético, um sólido amorfo corresponde a um estado de não-equilíbrio de um material que pode tomar uma variedade de diferentes estados microscópicos dependendo do processo de preparação [4]. Como a escala de tempo envolvida na transformação inversa (espontânea) é muito longa, pode-se dizer que o estado macroscópico de um sólido amorfo praticamente não se altera. Além disto, a entropia é comparável àquela presente nos líquidos, enquanto a entalpia é muito maior que a observada em cristais.

\section{Estruturas atômica \& eletrônica}

A partir da discussão acima, pode-se afirmar que sólidos amorfos são materiais que apresentam um alto grau de desordem. Assim como os sólidos cristalinos, dependendo de suas propriedades, os sólidos amorfos podem ser classificados em várias categorias. Os semicondutores amorfos, por exemplo, podem ser definidos como "materiais de estrutura desordenada que apresentam propriedades semicondutoras". Um cristal infinito ideal é caracterizado pela disposição regular dos átomos ao longo de sua rede. Dois aspectos relativos a este tipo de ordem podem ser destacados: a chamada ordem de curto alcance SRO (short-range order) e a ordem de longo alcance LRO (long-range order). Por ordem de curto alcance entende-se o arranjo regular dos átomos na vizinhança imediata de um átomo considerado (Figura 2). Grosso modo, a ordem de curto alcance determina 0 campo eletrostático no qual os átomos encontram-se sendo, portanto, responsável por várias das propriedades apresentadas pelo material em questão [5]. A ordem de longo alcance, por sua vez, está associada à existência da periodicidade estrita (também chamada de invariância translacional) ao longo da estrutura do material. Sob o ponto de vista teórico, a ordem de longo alcance é vital para o cálculo de bandas através da utilização do Teorema de Bloch [6]. Deve-se notar, contudo, que a ordem de longo alcance não é a responsável exclusiva por várias das propriedades físicas dos sólidos [4,7]. A idéia de uma rede atômica infinita e não perturbada é apenas uma idealização extremamente útil para o cálculo das funções de onda de elétrons e de buracos quando na determinação da estrutura de bandas e das propriedades de estado sólido. $\mathrm{Na}$ realidade, as estruturas cristalinas sempre apresentam algum tipo de perturbação, seja ela devida à extensão finita do cristal, pela presença de imperfeições na rede, ou por excitações elementares. Sob este contexto, a presença de desordem na estrutura atômica é um dos principais aspectos que distingue os sólidos amorfos dos cristalinos e, diga-se de passagem, é de importância fundamental no tratamento teórico destes semicondutores. A ausência de uma estrutura ordenada nos semicondutores amorfos, no entanto, torna necessário o emprego de outro tipo de aproximação para o tratamento teórico. Convém salientar que, embora amorfo, tais 
semicondutores apresentam estruturas com ordem química local ou SRO. Sendo assim, cálculos ab initio são largamente empregados no estudo deste tipo de materiais [8], a configuração atômica sendo descrita por meio de macromoléculas (denominadas redes de Bethe [9]).

(a)

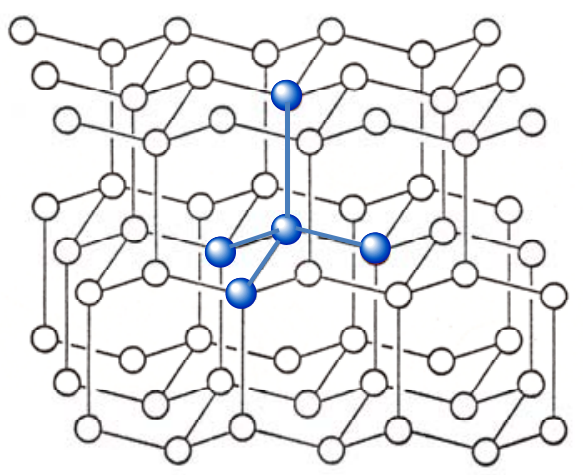

(b)

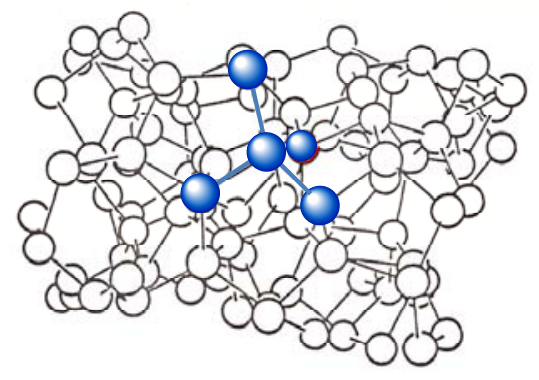

Figura 2 - Representações artísticas (tri-dimensionais) de: (a) uma estrutura tetraedricamente coordenada (Si cristalino, por exemplo), e (b) uma estrutura desordenada correspondente ao Si amorfo (a-Si). Em detalhe, em azul, as células unitárias de cada uma das representações. Ainda que as estruturas em (a) e em (b) estejam baseadas na mesma unidade elementar (tetraedro com átomos de $\mathrm{Si}$ ), apenas a primeira apresenta ordem de longo alcance.

A presença de desordem nos semicondutores amorfos é ainda responsável por várias outras características de extrema importância nas propriedades opto-eletrônicas destes materiais. Como se sabe, uma propriedade fundamental dos semicondutores ou isolantes é a presença de um bandgap ou separação energética entre os estados ocupados da banda de valência e os estados vazios da banda de condução. Segundo a teoria de elétrons livres, este bandgap é uma consequência da periodicidade da rede cristalina [6]. Este tipo de consideração, no entanto, gerou grandes debates no passado já que os semicondutores amorfos, apesar da ausência de ordem de longo alcance, também apresentavam um bandgap (melhor denominado de bandgap de mobilidade). Investigações posteriores elucidaram este fato levando-se em conta que o bandgap nos semicondutores pode ser equivalentemente descrito pela separação entre os estados ligantes e antiligantes relativos às ligações covalentes, por exemplo. Em outras palavras, a disposição das bandas de valência e de condução num semicondutor está fortemente influenciada pela ordem de curto alcance, que é a mesma - tanto no caso cristalino quanto no caso amorfo. Discussões detalhadas a este respeito podem ser encontradas em [10] e em [11]. Resumidamente, os três principais aspectos dos semicondutores amorfos são: a presença da ordem de curto alcance, a ausência de invariância translacional, e a existência de defeitos de coordenação. A presença da ordem de curto alcance resulta em estruturas eletrônicas semelhantes entre amorfos e cristais. As bem definidas e íngremes bordas das bandas de valência e de condução no caso cristalino são, no entanto, substituídas por caudas alargadas e estados dentro do bandgap em consequência da presença da chamada desordem topológica no caso amorfo (ver Figura 3). Tanto os defeitos profundos quanto os estados de cauda (também chamados de dangling bonds e de band tails, respectivamente) correspondem a estados localizados e são de grande importância nas propriedades opto-eletrônicas destes semicondutores. 


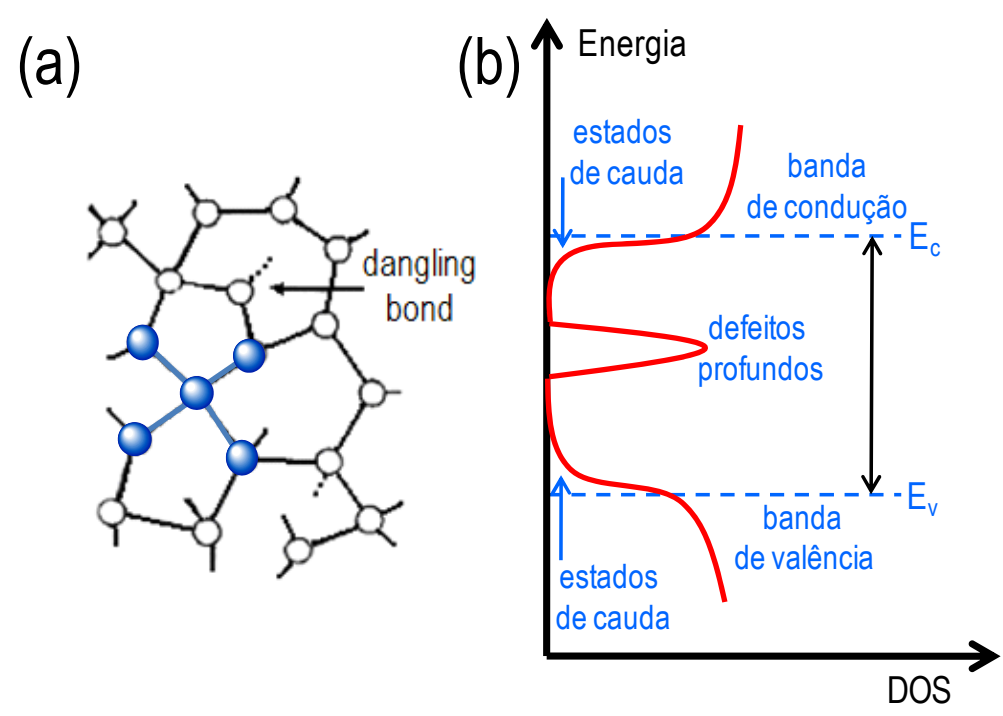

Figura 3 - (a) Representação artística (bi-dimensional) da estrutura atômica de um semicondutor tetraedricamente coordenado, apresentando variações nos ângulos e comprimentos das ligações químicas, e dangling bonds. (b) Representação da densidade de estados eletrônicos (DOS- density of states) para um semicondutor amorfo. As linhas pontilhadas ( $E_{c}$ e $E_{v}$ ) identificam os estados eletrônicos tipicamente encontrados em um semicondutor cristalino.

Os estados eletrônicos nos semicondutores amorfos são, então, compostos por estados estendidos (as bandas de valência e de condução) e por estados localizados (envolvendo defeitos profundos e estados de cauda), conforme pode ser apreciado na Figura 3. Outro aspecto importante com relação à ausência de ordem de longo alcance é o fato de o vetor de onda $\mathbf{k}$ não ser um número quântico adequado para a representação destes materiais e, portanto, não exibir propriedade alguma de conservação. Como consequências diretas temos que: (1) as bandas de energia não mais são descritas por relações de dispersão do tipo $E-k$, mas sim através da distribuição de estados $\mathrm{N}(\mathrm{E})$; (2) as regras de seleção de conservação de momento não se aplicam às transições ópticas tal que, transições ópticas ocorrem entre estados que apresentam superposição de funções de onda no espaço real e; (3) a desordem reduz significativamente a mobilidade dos portadores em função do espalhamento dos mesmos e do caráter localizado das funções de onda. Maiores detalhes podem ser encontrados em referências mais específicas [5,12,13].

Apesar das "limitações" impostas ao tratamento teórico dos semicondutores amorfos, convém lembrar que os mesmos são de grande interesse tanto acadêmico quanto tecnológico. Sob o ponto de vista teórico, os semicondutores amorfos representam um desafio e, ao mesmo tempo, uma fonte de novas informações. Quanto aos interesses comerciais, os últimos anos têm sido caracterizados pela busca de materiais com novas propriedades e/ou atributos não presentes em outros. Neste contexto, os semicondutores amorfos apresentam consideráveis atrativos, dentre os quais: envolvem uma tecnologia bastante conveniente em termos econômicos; podem ser depositados, em princípio, sob qualquer tipo de substrato (de baixo ponto de fusão e/ou flexíveis, por exemplo); dado o seu caráter amorfo, podem absorver mais radiação sob a forma de filmes finos; ao contrário dos seus análogos cristalinos podem ser processados e utilizados sob a forma de grandes áreas (interesses voltados para a conversão fotovoltáica e para a construção de telas planas, por exemplo); etc. São também, de extrema versatilidade quanto às suas características opto-eletrônicas. Em outras palavras, dependendo da composição e/ou forma de obtenção podem combinar propriedades bastante diversas tais 
como bandgap óptico, número e mobilidade de portadores, densidade de defeitos, etc. [5,14]. Além disto, uma rede amorfa incorpora facilmente átomos de diferente coordenação, resultando numa relativa facilidade de dopagem ou formação de ligas. Esta particularidade possui importantes implicações em suas propriedades estruturais e opto-eletrônicas finais e, principalmente, na sua eventual utilização em dispositivos. Em função destas características, elementos das mais variadas espécies têm sido empregados na dopagem de semicondutores amorfos que são preparados, geralmente, sob a forma de filmes finos.

\section{Formação de filmes finos}

Conforme mencionado ao longo das seções anteriores, os semicondutores amorfos caracterizam-se pela presença de uma estrutura atômica irregular. Isto em parte, está associado aos processos de obtenção deste tipo de material. Geralmente, a condensação rápida a partir da fase de vapor (fazendo com que os átomos fiquem "congelados" tão logo cheguem ao substrato) é a forma mais empregada. Várias são as técnicas pelas quais os semicondutores amorfos, sob a forma de filmes finos $(\sim \mu \mathrm{m})$, podem ser obtidos. Vários e de grande complexidade são, também, os fenômenos físicos/químicos envolvidos durante a deposição destes chamados filmes finos. Entre as técnicas de maior importância, estão aquelas assistidas por plasma (sputtering e glow discharge, por exemplo). Grosso modo, plasma é uma coleção de partículas neutras e carregadas resultantes da ionização parcial de átomos e moléculas de um gás - geralmente por meio da aplicação de um campo elétrico externo. Para os casos de interesse na deposição de filmes finos, o grau de ionização do plasma é tipicamente da ordem de $10^{-4}$, de forma que é composto, em sua maior parte, por partículas neutras $[15,16]$. Densidades típicas são da ordem de $10^{9}-10^{12}$ espécies $\mathrm{cm}^{-3} \mathrm{e}$, as partículas costumam apresentar distribuições de energia do tipo não-maxwelliana, com energias entre 2 e $10 \mathrm{eV}$ (correspondendo a elétrons com temperaturas entre $10^{4}-10^{5} \mathrm{~K}$ ).

Especificamente relacionado ao processo de deposição, as espécies advindas do plasma podem ser "adsorvidas" na superfície do substrato e então evaporar, migrar ou colidir e, eventualmente, combinar para a formação de núcleos ou aglomerados de partículas, num fenômeno denominado de nucleação (processos 1, 2 e 3, Figura 4). A formação e/ou o crescimento dos vários núcleos resulta do contato entre os vizinhos mais próximos dando origem à formação de "ilhas" de material (processos 4 e 5, Figura 4). E, por fim, as regiões ainda não preenchidas pelo material depositado (compostas por canais e/ou buracos superficiais) vão, pouco a pouco, desaparecendo através de processos de nucleação secundária dando origem ao filme fino (processos 6 e 7, Figura 4). Note-se que esta é uma visão bastante simplificada do processo de deposição de filmes finos e que, na realidade, outros fenômenos devem estar ocorrendo simultaneamente. Note-se também que, tanto a técnica quanto as condições de deposição são essenciais para o resultado final. Em outras palavras, dependendo da energia imposta às partículas, da temperatura e superfície do substrato e, dos tempos envolvidos nas reações, cada filme fino terá suas características próprias.

Com respeito à tecnologia de filmes finos aplica-se perfeitamente o conceito de que "o material é 0 processo". Em outras palavras, tanto a estrutura quanto a qualidade opto-eletrônica estarão determinadas exclusivamente pelo método e condições de deposição adotados. Lembre-se que, estas variáveis são responsáveis pelo mecanismo de crescimento em si (energia fornecida às espécies; temperatura e condições do substrato determinando a mobilidade superficial das partículas precursoras do filme em crescimento; tempos característicos envolvidos nos processos de migração, colisão, nucleação e coalescência; etc.). Dentro deste 
contexto destacam-se dois grandes grupos para a deposição de filmes finos: os chamados de métodos por vaporização física PVD (physical vapor deposition) e aqueles por vaporização química CVD (chemical vapor deposition). Tais denominações dizem respeito à forma pela qual as espécies precursoras reagem (em sua maioria) para a formação do filme fino: se envolvendo processos energéticos ou físicos (PVD) ou, se sujeitos a fenômenos menos energéticos à base de reações químicas (CVD). Convém mencionar, no entanto, que os processos de PVD e de CVD podem apresentar características muito semelhantes, dependendo das condições impostas à deposição (pressão total e composição relativa dos gases durante a deposição; potência aplicada ou energia entregue ao processo; polarização dos substratos; etc.).

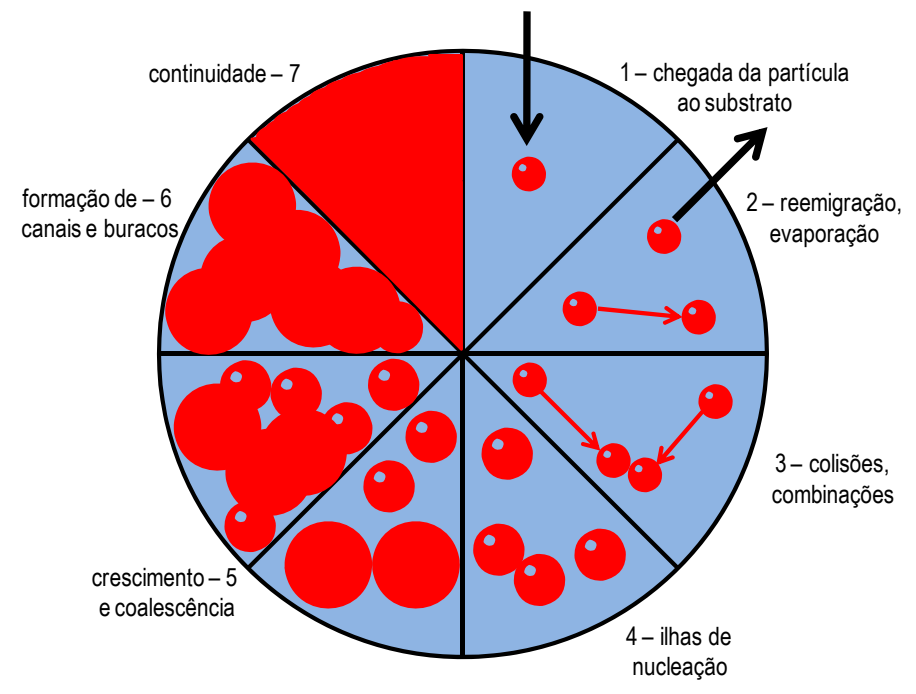

Figura 4 - Representação esquemática de alguns dos principais fenômenos que podem ocorrer durante a deposição de um filme fino. 1- chegada das partículas ao substrato (dependendo das condições impostas ao plasma: átomos neutros, espécies carregadas, aglomerados de espécies, etc.); $\mathbf{2}$ - tais partículas procuram se "acomodar" na superfície do substrato (da forma energeticamente mais favorável) ou retornar ao plasma; 3- as espécies depositadas ainda migram sobre a superfície do substrato, podendo sofrem colisões e formar agrupamentos de partículas dando origem às chamadas ilhas de nucleação (4); 5- mais e mais partículas vão se aglomerando ao redor das ilhas de nucleação e coalescendo entre si; 6 - apesar do processo de coalescência entre as ilhas, ainda restam regiões sem material depositado (regiões energeticamente desfavoráveis e/ou de muito baixa mobilidade superficial); e 7toda a superfície do substrato está recoberta pelo filme (continuidade).

Apesar das diferenças envolvendo os fenômenos microscópicos de crescimento dos filmes, as técnicas de CVD e PVD apresentam algumas semelhanças: ambas são realizadas sob vácuo e com um fluxo dinâmico de gases (geralmente as espécies precursoras do filme a ser formado) e, o processo de deposição é sustentado energeticamente através da aplicação de campos elétricos externos [15-17]. No processo de glow discharge 0 filme é formado, predominantemente, pela dissociação das moléculas do gás empregado (misturas de $\mathrm{SiH}_{4}$ para a deposição de a-Si:H e, misturas de $\mathrm{GeH}_{4}$ para a-Ge:H). Já no processo de sputtering, as espécies precursoras do filme são, em sua grande maioria, advindas de um alvo sólido (alvos cristalinos das espécies desejadas). 0 gás argônio é largamente empregado nos processos de sputtering, tendo como função principal arrancar partículas do alvo sólido [18]. Além do argônio, também é possível realizar as deposições empregando-se gases como nitrogênio, oxigênio e hidrogênio, ou uma mistura destes. Neste caso, temos o que se chama de deposição reativa, onde as espécies gasosas (exceto o argônio) farão parte da composição final 
do filme assim produzido. Dependendo das características, e proporção relativa dos gases empregados, podese preparar filmes dopados ou sob a forma de ligas (nitretos, óxidos, etc.). Precursores sólidos também podem ser considerados para a deposição de filmes dopados ou sob a forma de ligas. A este procedimento dá-se 0 nome de cosputtering e é conseguido a partir do recobrimento parcial da superfície do alvo com o elemento desejado (Figura 5). Assim como no caso da deposição reativa (precursores gasosos), a concentração do filme estará determinada pelas áreas relativas ocupadas pelos elementos que compõem o alvo:

$$
\frac{[\text { elemento } A]}{[\text { elemento } B]} \cong \frac{A_{A} Y_{A}}{A_{B} Y_{B}}
$$

Neste caso, os precursores sólidos estão indicados pelas letras $A$ e $B$ e suas respectivas áreas ocupadas por $A_{A}$ e $A_{B}$. Da mesma forma, o sputtering yield ou eficiência de pulverização dos elementos $A$ e $B$ estão indicados por $Y_{A}$ e $Y_{B}$. Enquanto as áreas $A_{A}$ e $A_{B}$ são definidas a partir da concentração relativa $[A]$ / $[B]$ desejada, uma estimativa para os valores de sputtering yield pode ser facilmente conseguida em livros $[15,18]$ ou tabelas especiais [19].

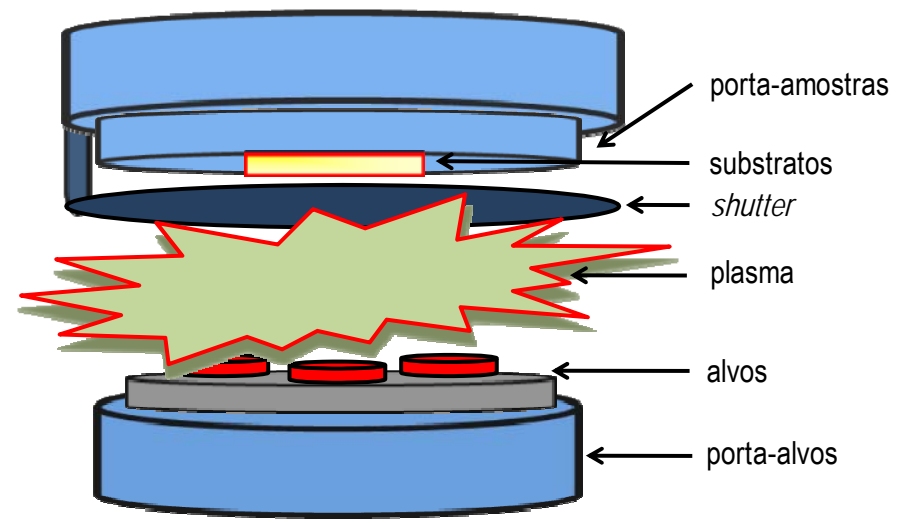

Figura 5 - llustração do processo de cosputtering destacando os seguintes elementos: porta-amostras (removivel e com recursos para aquecimento dos substratos durante a deposição); substratos (qualquer meio material compatível com vácuo e com a temperatura de deposição); shutter (obstrução mecânica que preserva os substratos enquanto as condições do plasma são ajustadas); plasma (coleção de partículas ionizadas, formada a partir dos gases e alvos empregados); alvos (precursores sólidos que darão origem ao filme em formação); e porta-alvos (eletrodo polarizado).

Muito do trabalho aqui descrito foi baseado em filmes preparados pela técnica de sputtering de rádio frequência (ou rf sputtering). Essencialmente, filmes de silício amorfo (a-Si) e germânio amorfo (a-Ge) contendo hidrogênio (a-Si:H e a-Ge:H), nitrogênio (a-SiN e a-GeN), dopados com elementos diversos (metais, metais de transição, íons terra-rara), etc. Da mesma forma, a técnica prestou-se ao preparo de filmes de nitreto de alumínio (a-AIN) e de compostos do tipo a-GaAsN. A técnica em si é bastante simples e versátil na medida em que permite a produção de filmes finos com composições determinadas pela atmosfera gasosa e pela constituição dos alvos sólidos. Sob condições normais de deposição (temperatura $\sim 100{ }^{\circ} \mathrm{C}$, pressão $\sim 1-10$ mTorr, taxa 10-300 nm/h, etc.), no entanto, os filmes produzidos pela técnica de rf sputtering são, predominantemente, amorfos - em perfeito acordo com o fato de o processo de deposição ocorrer fora do equilíbrio termodinâmico. Enquanto, para alguns, tal aspecto pode sugerir que a técnica não seja adequada ao estudo de materiais, para outros, o preparo de materiais de estrutura amorfa representa uma fonte quase que infinita de possibilidades. Mediante a técnica de rf sputtering filmes finos podem ser preparados sob as mais 
diversas composições (e propriedades), terem a sua estrutura (e composição) alterada por intermédio de tratamentos pós-deposição, etc.

\section{Estabilidade térmica \& estrutural}

Conforme discutido anteriormente, um sólido amorfo é uma substância que se encontra em não-equilíbrio e que, dependendo do método e condições de preparo, pode assumir diferentes estados macroscópicos. Caracteriza-se também por possuir uma energia livre $G$ fora de um valor mínimo [Figura 1(b)] e, portanto, é susceptível a perturbações externas. Mais especificamente, sua condição de energia livre pode ser alterada (reversível ou irreversivelmente) - desde que a barreira energética entre dois estados distintos possa ser vencida - a partir de processos externos tais como tratamentos térmicos, por exemplo. Este é um aspecto marcante dos semicondutores amorfos, e está diretamente relacionado às suas características termodinâmicasestruturais, de grande interesse acadêmico-tecnológico.

Para o caso específico de filmes de silício amorfo (a-Si), por exemplo, quando submetidos a temperaturas acima de um determinado valor, começam a se transformar em silício cristalino (c-Si). Em função dos métodos tipicamente empregados no seu preparo (CVD ou PVD), no entanto, vale lembrar que ao contrário de materiais vítreos preparados por resfriado rápido na fase líquida, os conceitos de fase líquida super-resfriada e de transição vítrea não estão claramente definidos na rede aleatória do Si. Mesmo porque, a temperatura de cristalização em filmes finos é consideravelmente afetada pela natureza do substrato, pela presença de impurezas, pelo grau de interação filme-substrato, pela temperatura do substrato no momento da preparação, pela espessura dos filmes, e vários outros fatores. Além destes, sob o aspecto termodinâmico, o processo de cristalização é afetado de forma significativa não somente pela energia livre do volume (bulk) mas, também, pelas energias livres interfaciais e/ou de superfície $[3,14,18]$. A fim de ilustrar a discussão, consideremos um filme de a-Si tratado a 300, 450, 600 e $750{ }^{\circ} \mathrm{C}$ por intervalos (cumulativos) de 15, 30, 45, 60, 90 e 120 min (Figura 6). 0 filme foi depositado por if sputtering (temperatura de deposição $\sim 100{ }^{\circ} \mathrm{C}$, substrato de vidro, espessura de $\sim 1 \mu \mathrm{m}$ ) e apresenta estrutura amorfa como pode ser verificado mediante os espectros de espalhamento Raman.

Dentre as possíveis metodologias de tratamento térmico, a Figura 6 ilustra resultados do chamado tratamento isotérmico onde, para uma dada temperatura, os tratamentos são feitos com durações crescentes. Outra possibilidade, igualmente utilizada, é o tratamento isócrono onde, os tempos são mantidos constantes para temperaturas crescentes. Além de permitir abordagens complementares, a realização de tratamentos isotérmicos e isócronos possibilita a investigação de novas rotas e/ou da cinética de formação de estruturas cristalinas a partir de filmes finos amorfos. Dentro deste contexto é interessante observar que o fator determinante na cristalização dos filmes de a-Si é essencialmente a temperatura (ou altura da barreira energética amorfo $\rightarrow$ cristal).

Para os tratamentos isócronos (processo cumulativo e com duração de 15 minutos cada), por exemplo, a cristalização de filmes de a-Si ocorre entre $600-700{ }^{\circ} \mathrm{C}$. Para os tratamentos isotérmicos, a cristalização dos mesmos filmes manifesta-se apenas em $\sim 750^{\circ} \mathrm{C}$ e torna-se mais efetiva para durações maiores. Este é um resultado de grande importância e deixa clara a possibilidade de se controlar, gradual e continuamente, a fração cristalina em filmes de a-Si (ou qualquer outro filme semicondutor amorfo). Em adição aos tratamentos térmicos convencionais deve-se mencionar, ainda, outras possíveis rotas para a cristalização de materiais 
amorfos: induzida por espécies metálicas (MIC- metal induced crystallization); induzida por radiação laser (LIClaser induced crystallization); induzida pela aplicação de um potencial elétrico (CIC- current induced crystallization); induzida pela aplicação de deformações externas (PIC- pressure induced crystallization); bem como combinações destas. Dentre estas, discutiremos em relativo detalhe apenas as técnicas de MIC e LIC.
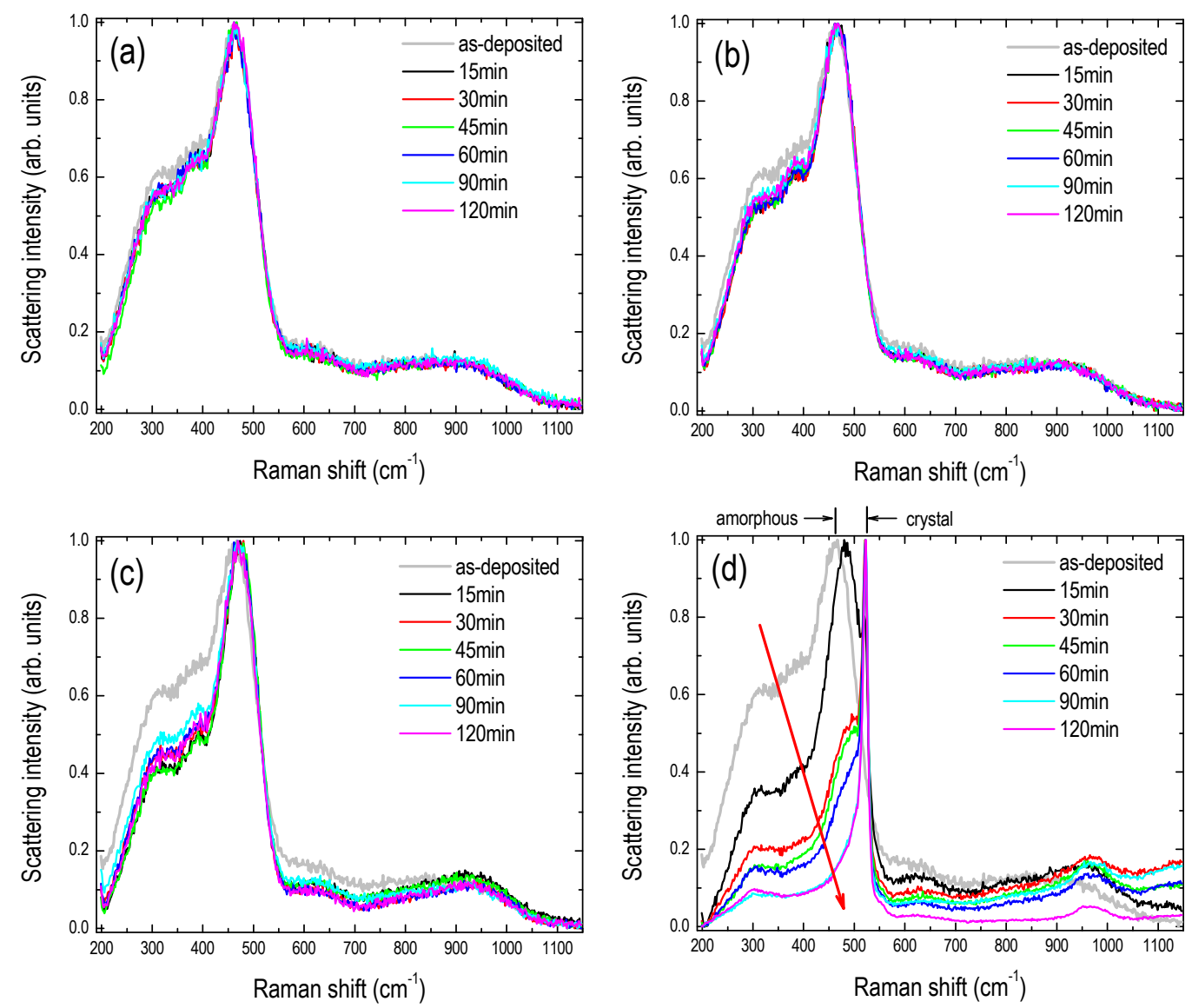

Figura 6 - Espectros de espalhamento Raman obtidos de filmes de a-Si (espessura $\sim 1 \mu \mathrm{m}$ ) tratados a (a) $300{ }^{\circ} \mathrm{C}$, (b) $450{ }^{\circ} \mathrm{C}$, (c) $600{ }^{\circ} \mathrm{C}$, e (d) $750{ }^{\circ} \mathrm{C}$ durante $15,30,45,60,90$, e 120 minutos. Observe que, enquanto tratamentos térmicos a 300,450 e $600{ }^{\circ} \mathrm{C}$ produzem pequenas variações nos espectros (e na estrutura dos filmes), a $750^{\circ} \mathrm{C}$ pode-se verificar a cristalização gradual do filme de a-Si. Variações sistemáticas na posição do modo vibracional principal (transverso-óptico em $\sim 480 \mathrm{~cm}^{-1}$ ), que experimenta um blueshift, estão associadas à diminuição da desordem do material. De maneira análoga, a intensidade dos modos de menor energia (Iongitudinal-óptico e longitudinal-acústico em $\sim 400$ e $350 \mathrm{~cm}^{-1}$, respectivamente) diminui para tratamentos térmicos mais longos.

\section{Cristalização}

\section{Cristalização induzida por espécies metálicas (MIC- metal induced crystallization)}

Já há mais de quatro décadas sabe-se que filmes de silício amorfo (a-Si) e de germânio amorfo (a-Ge) cristalizam a baixas temperaturas quando colocados em contato com metais como $\mathrm{Al}, \mathrm{Au}, \mathrm{Ag}$, etc. [20-22]. Curiosamente, tais temperaturas de cristalização costumam ser $100-300{ }^{\circ} \mathrm{C}$ menores que aquelas tipicamente encontradas tanto para o ponto eutético quanto para o de cristalização térmica destes filmes (Figura 7). Desde então, o assunto tem atraído a atenção de pesquisadores e tecnólogos não somente pelo desafio em compreender os mecanismos que levam à MIC mas, principalmente, pelas possíveis aplicações do fenômeno. 
Como exemplo, vale mencionar a investigação do processo de MIC no a-Ge [23] e no a-Si [24] como processo alternativo para a fabricação de dispositivos (micro-)eletrônicos a partir de filmes depositados sobre substratos incompatíveis com altas temperaturas.
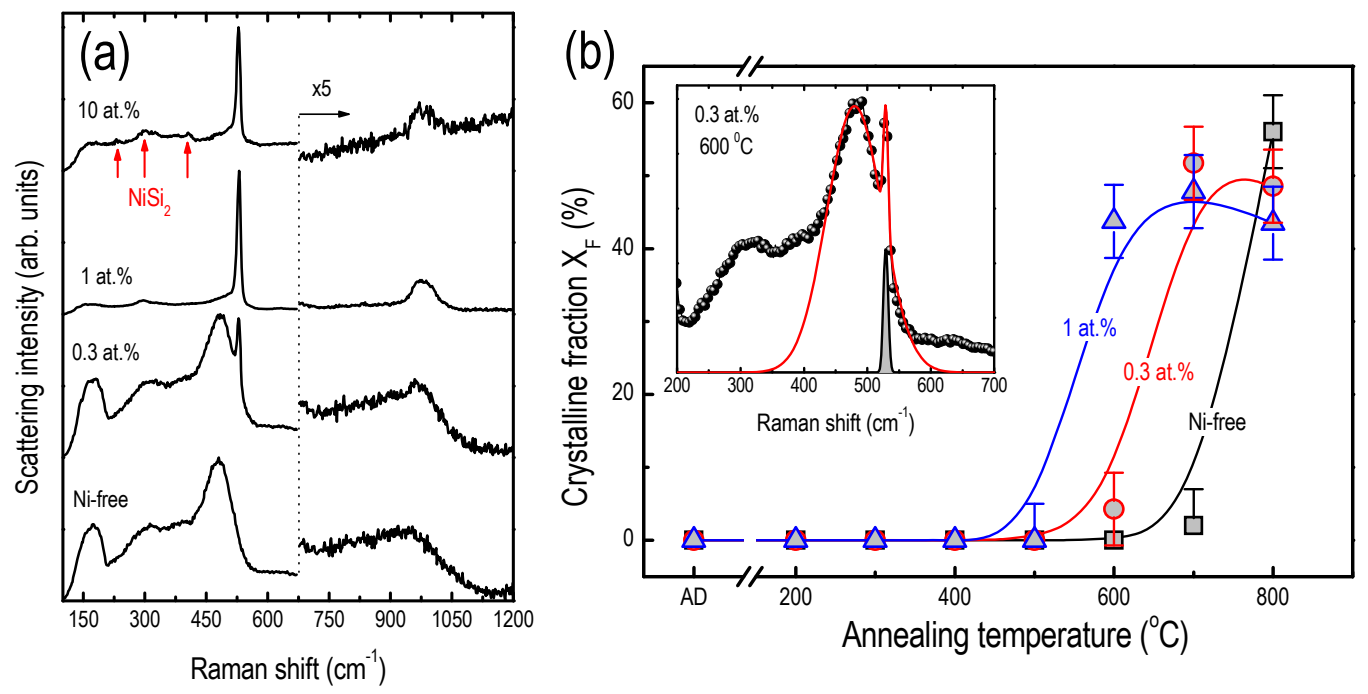

Figura 7 - (a) Espectros de espalhamento Raman de filmes de a-Si $(\sim 1 \mu \mathrm{m})$ tratados a $600{ }^{\circ} \mathrm{C}$ por $15 \mathrm{~min}$, com diferentes concentrações de Ni: 0, 0.3, 1 e 10 at.\%. As principais contribuições em 175, 310, 480, 520, e $980 \mathrm{~cm}^{-1}$ devem-se aos modos vibracionais do silício: TA, LA+LO, TO (do a-Si), TO, e 2TO do c-Si. Para altas concentrações de Ni também são evidentes modos devidos ao surgimento da fase $\mathrm{NiSi}_{2}$. (b) Representação da fração cristalina (conforme determinada a partir da razão de áreas entre as contribuições em $\sim 520$ e $480 \mathrm{~cm}^{-1}-$ insert) para filmes contendo [Ni] $=0,0.3$ e 1 at. \% e tratados a diferentes temperaturas. Note a dependência da temperatura de cristalização com a concentração de Ni presente nos filmes de a-Si.

Atualmente, acredita-se que a MIC em filmes de a-Si e de a-Ge tem início a partir da nucleação de átomos de Si (ou de $\mathrm{Ge}$ ) ao redor de "sementes" de cristalização. Este processo de nucleação produz cristalitos (nanoou micro-cristais) cujo tamanho final depende de vários detalhes experimentais tais como: concentração de espécies atômicas; condições de tratamento térmico (temperatura, atmosfera, duração, etc.); presença de contaminantes (não-)intencionais; natureza e temperatura do substrato; espessura das camadas (no caso de estruturas do tipo multicamadas); etc. Argumenta-se que este processo tenha origem a partir da diferença de energia livre existente entre as fases amorfa e cristalina [25] que, aliada à tensão superficial presente, determina o tamanho e distribuição dos cristalitos. Contudo, os mecanismos microscópicos da MIC em filmes de a-Si e a-Ge a baixas temperaturas ainda não estão totalmente esclarecidos. Até o momento, a grande maioria dos estudos sobre cristalização induzida por espécies metálicas foi realizada em estruturas do tipo multicamadas, onde se depositam alternadamente camadas metálicas e semicondutoras de espessura variável. A investigação da influência da espessura destas camadas metálicas e das interfaces metal-semicondutor tem apresentado algumas informações importantes. Jin et al. [26], por exemplo, argumentam que a cristalização de filmes de a-Si induzida por superfícies de níquel é uma reação que ocorre na fase sólida e que o níquel atua como um meio para a nucleação e crescimento da fase cristalina do $\mathrm{Si}$. O foco deste estudo, assim como o de muitos outros, no entanto, é a análise da interface Si-Ni e tem, como conclusão principal, que a difusão de átomos do semicondutor no metal (ou vice-versa) é o mecanismo microscópico fundamental que leva à 
cristalização. Argumenta-se, também, que o desenvolvimento do Si cristalino esteja associado à presença de precipitado de $\mathrm{NiSi}_{2}$ [27], por exemplo. O que dá origem a esta difusão de espécies e/ou cristalização, contudo, permanece ainda inconclusivo e baseado em especulações diversas.

Tendo por base este cenário, em meados de 2005 demos início ao estudo sistemático dos mecanismos de cristalização em filmes de a-Si com diferentes concentrações de Ni. Como diferencial do trabalho realizado, vale ressaltar as seguintes características: (1) todas as amostras investigadas foram preparadas pela técnica de rf sputtering, que permite grande controle sobre a composição e espessura dos filmes (em contraposição aos estudos tradicionais envolvendo filmes multicamada do tipo a-Si/metal); (2) os tratamentos térmicos adotados foram do tipo isócrono com temperaturas na faixa de $200-1000{ }^{\circ} \mathrm{C}$, com duração de 15 min cada (enquanto na literatura, geralmente, empregam-se tratamentos não-sistemáticos da ordem de 1-10 h); e (3) as sucessivas etapas do processo de cristalização, bem como o eventual surgimento de fases complementares, foram investigadas pela técnica de espectroscopia Raman (em detrimento da tradicional difração de raios-x) que, além de extremamente rápida e sensível, permite a realização de medidas com grande resolução espacial. Muitos dos resultados obtidos acerca da cristalização induzida por espécies metálicas (MIC) em filmes de a-Si serão apresentados em seções posteriores.

\section{Cristalização induzida por radiação laser (LIC- laser induced crystallization)}

Muitos dos trabalhos envolvendo a utilização de radiação laser na área de Ciência de Materiais têm por objetivo a busca por novos materiais (e/ou estruturas) ou, ainda, metodologias mais eficientes para o processamento e fabricação de dispositivos semicondutores [28,29]. Além do mais, a técnica possibilita a realização de tratamentos com grande resolução espacial, e é perfeitamente compatível com o processamento de filmes finos sobre substratos simples e de baixo ponto de fusão - característica nem sempre satisfeita quando da realização de tratamentos térmicos em fornos convencionais. A efetiva utilização da técnica de LIC, no entanto, requer algum conhecimento das propriedades ópticas-eletrônicas do material em questão. Isto deve-se ao fato de que muitas destas propriedades irão determinar tanto o processo de geração (absorção da radiação) quanto de transferência de calor. Dependendo destas propriedades (e dos resultados esperados) a técnica pode ser feita a partir de radiação laser contínua (cw- continuous wave) ou pulsada.

Quando da utilização de radiação laser pulsada, parte da energia incidente é refletida e parte absorvida e rapidamente transferida à rede. Isto pode levar à fusão de uma camada do material cuja espessura será função do comprimento de absorção óptico ( $\alpha^{-1}$, onde $\alpha$ representa o coeficiente de absorção) entre outras variáveis. A camada fundida (líquida) experimenta um processo de re-solidificação a partir da interface líquido-sólido o qual pode dar origem a estruturas perfeitamente ordenadas (cristal) ou não (Figura 8). No primeiro caso, convém mencionar o mecanismo de crescimento epitaxial (LPE- liquid phase epitaxy) em que a cristalização tem origem no substrato ou a partir de centros de nucleação presentes no material. Embora a cristalização seja o mecanismo de solidificação mais energeticamente favorável, a ocorrência de estados de não-equilíbrio durante o processo de LIC pode levar a camada líquida à solidificação sob a forma amorfa. Este fenômeno costuma ocorrer quando a velocidade de re-solidificação é muito elevada ( 15-20 m/s no caso do silício) [30].

Já no caso do tratamento de materiais mediante a utilização de radiação laser cw, o processo é muito distinto: os tempos envolvidos são consideravelmente maiores (ms-min) e, nem sempre, é possível levar o material à sua forma fundida. Deste modo, a cristalização pode ocorrer através de crescimento epitaxial a partir 
da fase sólida (SPE- solid phase epitaxy), ou por intermédio de centros de nucleação. Investigações do processo de LIC do Si amorfizado por implantação iônica mostram que os mecanismos físicos da recristalização LIC cw são, em muitos aspectos, semelhantes ao tratamento térmico convencional [31]. Neste momento é importante discutir acerca das diferenças entre os mecanismos de solidificação a partir das fases sólida e líquida (os quais passaremos a tratar genericamente de SPE e LPE, respectivamente). No caso da SPE, além de o material não ter atingido o ponto de fusão, a taxa de re-solidificação depende do modo como a quebra de ligações e as configurações atômicas se comportam com a temperatura. Isto porque o processo de re-solidificação ocorre na própria fase sólida e é controlado pela quebra de ligações fracas e re-organização de ligações pendentes. Se, por outro lado, o material chega a ser fundido (LPE), todos os defeitos são aniquilados ainda na fase líquida, e qualquer outro defeito que possa restar na fase sólida final é devido ao próprio processo de re-solidificação [29].
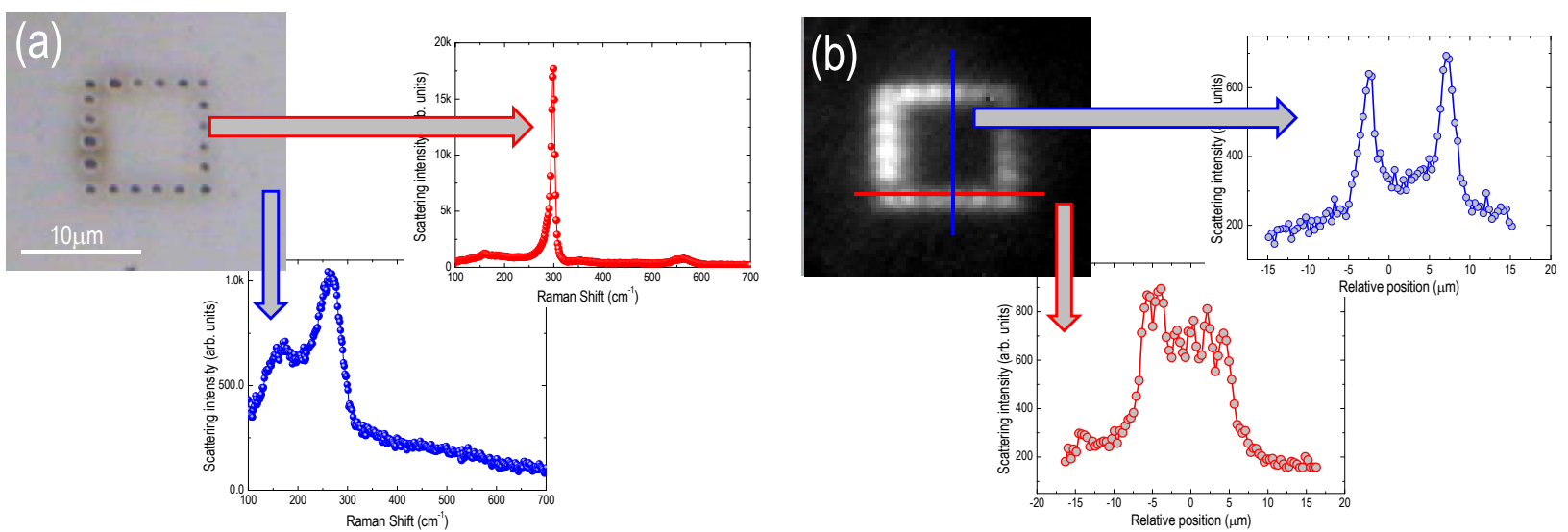

Figura 8 - Exemplo do processo de cristalização induzida por radiação laser (LIC) de um filme de a-Ge depositado sobre vidro. Em (a) temos uma micrografia óptica ilustrando um padrão gerado por radiação laser, e os espectros Raman relativos a regiões irradiadas e não-irradiadas. Enquanto a luz espalhada em $\sim 275 \mathrm{~cm}^{-1}$ indica se tratar de a-Ge, o sinal em $\sim 300 \mathrm{~cm}^{-1}$ deixa clara a presença de c-Ge. Em (b) temos a imagem Raman (representação bi-dimensional da intensidade do sinal Raman em $\sim 300 \mathrm{~cm}^{-1}$ ) do mesmo padrão apresentado em (a), bem como os perfis de intensidade, deixando evidente a geração de um padrão microscópico cristalino.

Sob o ponto de vista aplicado, em materiais semicondutores o processo de absorção de radiação laser pode ser dividido em dois grandes grupos: devido à excitação de portadores, e devido ao aquecimento da rede. Dentro deste contexto podemos identificar vários mecanismos, cujas proporções dependem de 0 material semicondutor apresentar estrutura amorfa ou cristalina: (1) fótons com energia hv muito menor que a energia do bandgap (Eg) podem excitar vibrações da rede diretamente. Este mecanismo tem um papel significativo quando o comprimento de onda da radiação utilizada coincide com vibrações da rede. Considerando-se que 0 comprimento de absorção $\alpha^{-1}$ pode variar desde centímetros até metros, este mecanismo apresenta limitações no efetivo aquecimento da amostra; (2) portadores livres ou quase-livres podem ser excitados com $\mathrm{h} v \leq \mathrm{Eg}$. $\mathrm{Na}$ verdade esse mecanismo está presente na absorção de qualquer comprimento de onda, mas é particularmente importante em materiais cristalinos altamente dopados, ou nos semicondutores amorfos; (3) para hv > Eg, a absorção devida à excitação de pares elétron-buraco $(e-h)$ pode ocorrer tanto direta quanto indiretamente neste último caso sendo assistida por fônons. Este é o mecanismo mais importante e o que mais contribui para 
o processo de LIC; e (4) em materiais semicondutores amorfos ou cristalinos com quebra de simetria da rede (via implantação iônica, por exemplo), a ausência de regras de seleção para o processo de absorção óptica aumenta consideravelmente a eficiência da LIC. A absorção de radiação laser por um material semicondutor é um processo muito complexo, em especial, se considerarmos que a contribuição de cada um dos mecanismos acima descritos costuma variar durante o tratamento. Não bastasse isto, uma vez absorvida, a energia proveniente da radiação laser é re-distribuída pelo material mediante: (a) colisões entre portadores livres; (b) recombinação de pares $e-h$ pelo processo Auger (basicamente a aniquilação de um par $e-h$ com transferência da energia envolvida para outro elétron na banda de condução); (c) produção de pares $e-h$ por ionização de impacto (inverso do processo Auger); (d) emissão de fônons; etc. Vale mencionar que, enquanto os três primeiros processos apenas levam à re-distribuição de energia entre os portadores, o quarto resulta na transferência de energia para a rede - o que efetivamente provoca o aumento da temperatura do material.

Como fica evidente a partir da discussão acima, além das características da radiação laser incidente as propriedades ópticas-eletrônicas do material sujeito à LIC são determinantes no processo. Neste sentido, é importante ressaltar que os materiais amorfos atingem o estado líquido a temperaturas consideravelmente inferiores àquelas necessárias para o análogo cristalino. Quantitativamente, para o Si e para o Ge, tais diferenças podem ser de até 30\% [28,32].

Até o momento consideramos a técnica de LIC mediante a utilização de apenas um feixe de radiação laser (também chamada de cristalização induzida por radiação laser uniforme, ou LIC uniforme). No entanto, mais importante do que a simples fusão-re-solidificação de materiais, a técnica de LIC pode se prestar à cristalização seletiva (ou estruturação) destes. Para isto, faz-se com que a radiação proveniente de um único laser seja dividida em dois ou mais feixes, de forma a manter a sua coerência [33]. Após a separação, os feixes incidem sobre a superfície da amostra segundo um ângulo $\phi$ com a normal e produzem um padrão de interferência sob a forma de linhas paralelas. Como resultado do padrão de máximos e mínimos de intensidade luminosa assim gerado, haverá uma distribuição de temperaturas na superfície da amostra, em estreita correlação com o padrão original. Na realidade, esta distribuição de temperaturas dependerá do processo de absorção óptica e dos mecanismos de condução de calor no material, entre outros fatores. Considerando que, nas regiões em que a intensidade de radiação é máxima, a temperatura seja suficiente para fundir o material, haverá o surgimento de regiões seletivamente fundidas (ou liquefeitas) enquanto as demais permanecerão inalteradas. Cessada a incidência de radiação laser, ocorre o resfriamento e re-solidificação das regiões fundidas (Figura 9). $O$ período do padrão de interferência $P$, e consequente período de estruturação cristalina, é determinado a partir do comprimento de onda da radiação laser incidente e/ou do ângulo de incidência $\phi$ :

$$
P=\frac{\lambda}{2 \operatorname{sen} \phi}
$$

Um raciocínio análogo pode ser aplicado quando da utilização de três feixes de radiação. Neste caso, 0 padrão é gerado a partir da interferência de pares de feixes com a consequente produção de um padrão de pontos.

Dentre os seus principais atributos, a técnica de LIC seletiva (ou laser structuring) permite: (a) a confecção de padrões homogêneos (linhas ou pontos regularmente espaçados) com períodos desde sub- $\mu \mathrm{m}$ até $\sim 10 \mu \mathrm{m}$; (b) que a estruturação seja feita in situ, sem a necessidade de processos complementares (uso de máscaras ou métodos litográficos, por exemplo); (c) que uma mesma montagem experimental possa ser utilizada para a produção de diferentes estruturas, simplesmente alterando-se a geometria e/ou a fonte de radiação laser; (d) 
que os padrões de linhas ou pontos sejam utilizados para o crescimento de áreas cristalinas maiores - neste caso, as regiões cristalizadas seletivamente atuariam como "sementes" que, com o tratamento em fornos convencionais, dariam origem a grandes áreas cristalinas; e (e) que a remoção (etching) preferencial de alguma das duas regiões (amorfa ou cristalizada) produza uma estrutura regular tridimensional.

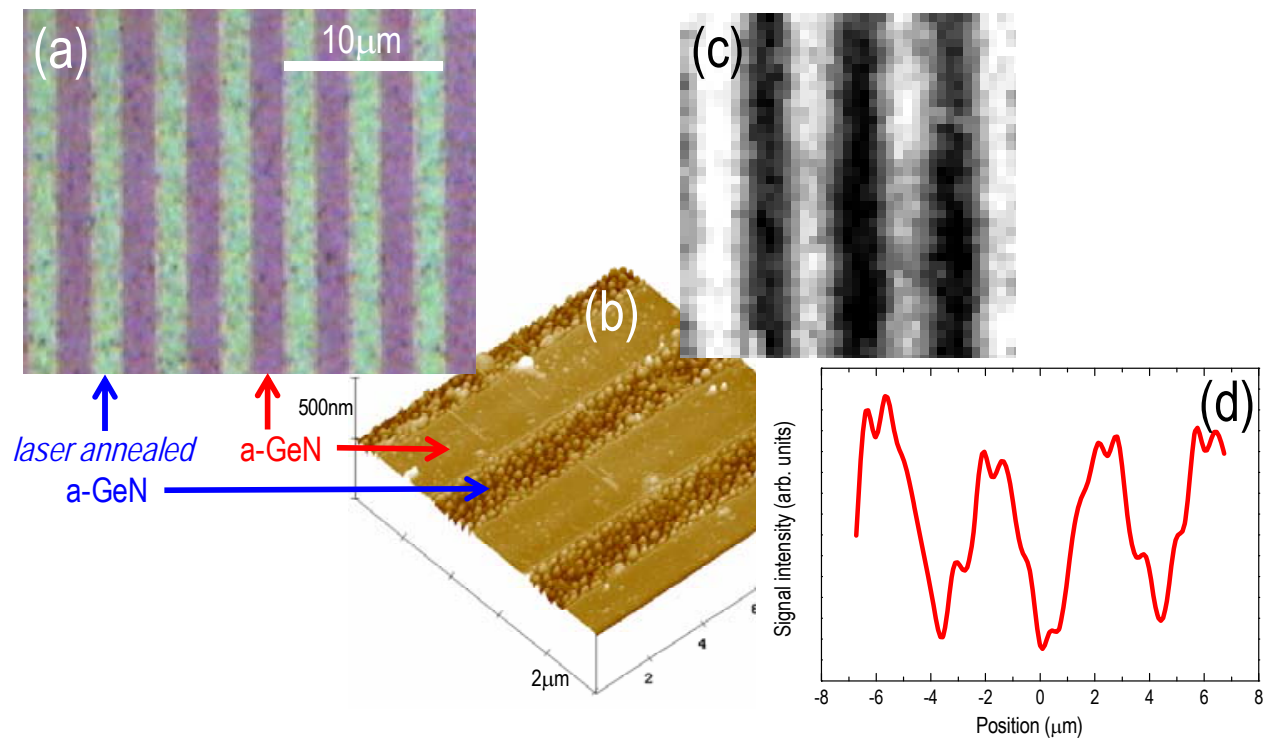

Figura 9 - llustração do processo de laser structuring (LIC com dois feixes de radiação laser) de um filme de a-GeN depositado sobre vidro: (a) micrografia óptica da superfície do filme de a-GeN após o processo de laser structuring (radiação incidente de $355 \mathrm{~nm}, 10$ ns, e $\phi \sim 2.5^{\circ}$ ), (b) imagem de AFM (atomic force microscopy), (c) imagem Raman destacando as regiões cristalizadas (com espalhamento em $\sim 300 \mathrm{~cm}^{-1}$ ), e (d) perfil de intensidade Raman obtido a partir de (c).

Com exceção das técnicas de CIC (current induced crystallization) e PIC (pressure induced crystallization), todas as demais (tratamento térmico convencional, MIC e LIC) foram empregadas em muitas das pesquisas realizadas no Lab. de Filmes Finos (IFSC). A fim de ilustrar em relativo detalhe alguns dos principais resultados assim obtidos, passemos à descrição dos trabalhos científicos publicados a respeito. 
Resultados Experimentais na área de

Cristalização de filmes finos

\section{Cristalização induzida por espécies metálicas MIC (metal induced crystallization)}

Parte 1 - O sistema Ge-Al

Data de 2001 o primeiro trabalho realizado no LFF, acerca da cristalização induzida por espécies metálicas em filmes semicondutores amorfos [34] - ver quadro a seguir. Na realidade, o fenômeno foi observado muito tempo antes, quando do estudo das propriedades de transporte eletrônico em filmes de germânio amorfo hidrogenado (a-Ge:H) dopados com impurezas aceitadoras [35]. 0 trabalho consistiu na inserção controlada de In, Ga e Al em filmes de a-Ge:H e a investigação das propriedades elétricas destes. Como o enfoque do trabalho era 0 de propriedades eletrônicas (e não estruturais) e, na ausência de facilidades específicas, 0 fenômeno deixou de receber a devida atenção. Quando do estabelecimento do LFF (por volta de 2000), as amostras de a-Ge:H dopadas com Al tiveram as suas propriedades ópticas e estruturais investigadas em detalhe: em função da concentração de Al e da temperatura de tratamento térmico [36]. O trabalho de 2001, no entanto, apresentava uma explicação fenomenológica para a cristalização dos filmes de a-Ge:H para uma concentração específica de Al - sem qualquer tratamento térmico. Baseado em resultados de EXAFS (extended x-ray absorption fine structure) do sistema $\mathrm{Ge}-\mathrm{Ga}$, foi sugerido que a cristalização "espontânea" dava-se a partir de átomos de Al tetraedricamente coordenados, os quais atuavam como centros para a nucleação dos cristalitos de Ge.

\section{Aluminum-induced crystallization of hydrogenated amorphous germanium thin films}

I. Chambouleyron, F. Fajardo, and A.R. Zanatta, Applied Physics Letters 79, 3233 (2001)

Abstract - Al-induced crystallization of cosputtered hydrogenated amorphous germanium films, deposited at $220^{\circ} \mathrm{C}$, onto crystalline silicon substrates is investigated by Raman and infrared spectroscopies as a function of the Al concentration $\left(2 \times 10^{-6}<[\mathrm{Al} / \mathrm{Ge}]<\right.$ $2.5 \times 10^{-2}$ ). Aluminum induces partial crystallization of the films for metal concentrations smaller than $\sim 1.3$ at. $\%$. A sort of explosive crystallization of the films occurs within a narrow Al concentration range $(\sim 1.3<[\mathrm{Al} / \mathrm{Ge}]<1.8$ at.\%). Raman spectra do not display any crystallization signal for metal concentrations above this narrow range. Data of the extended $\mathrm{x}$-ray absorption fine structure of the coordination and of the local order around gallium, in Ga-doped a-Ge:H, are used to propose an overall picture of the microscopic mechanisms behind these results. A comparative analysis suggests that the crystallization seeds are fourfold-coordinated Al atoms sitting at the center of perfect tetrahedral Ge sites.

Anos mais tarde, foi publicado um artigo estendido contendo uma descrição detalhada das propriedades estruturais dos filmes de a-Ge:H dopados com Al [37] - ver quadro a seguir. Além de dar suporte à explicação fenomenológica apresentada anteriormente, o trabalho levava em consideração o efeito de tratamentos térmicos convencionais sobre o processo de cristalização. Os filmes considerados foram exatamente os mesmos do trabalho anterior [34] - agora tratados termicamente até $500{ }^{\circ} \mathrm{C}$ (tratamentos cumulativos de 15 min cada). As técnicas experimentais utilizadas foram as de transmissão óptica na região do infra-vermelho (FTIR- Fourier transform infrared spectroscopy) e espalhamento Raman com especial atenção aos detalhes finos desta última (posição precisa e largura associada dos modos vibracionais, por exemplo). Desta forma foi possível explorar a cinética de cristalização dos filmes de a-Ge:H em função da composição ([Al]/[Ge] na faixa de $\sim 10^{-6}-10^{-2}$ ) e a influência dos átomos de hidrogênio presentes no material. Devido à superposição do sinal de fluorescência do Al com a borda de absorção do Ge, a ordem química local (conforme obtida a partir da técnica de EXAFS, por exemplo) não pode ser analisada para as amostras de a-Ge:H dopadas com Al. Este 
problema não ocorre para o sistema $\mathrm{Ga}-\mathrm{Ge}$, e experimentos de EXAFS foram realizados em amostras semelhantes de a-Ge:H dopadas com Ga [38]. Dentre os principais resultados obtidos, vale destacar: (1) na forma diluída (até $\sim 10^{-3}$ ), os átomos de Ga permanecem tetraedricamente coordenados $\left(\mathrm{Ga}_{4}\right)$, em perfeito acordo com as medidas de transporte eletrônico; (2) a ordem química ao redor do $\mathrm{Ga}_{4}$ aumenta com a concentração de impureza; e (3) a distância $\mathrm{Ga}-\mathrm{Ge}$ aumenta com [Ga] levando a um aumento no stress compressivo do filme. Dada a grande semelhança entre o Al e o Ga (estrutura dos elétrons de valência e raio da nuvem eletrônica), e tendo por base os estudos do sistema $\mathrm{Ge}-\mathrm{Ga}$ foi possível chegar a algumas conclusões importantes.

\section{Low-temperature Al-induced crystallization of amorphous $\mathrm{Ge}$}

A.R. Zanatta and I. Chambouleyron, Journal of Applied Physics 97, 094914 (2005)

Abstract - This work reports on the low-temperature crystallization of hydrogenated amorphous germanium (a-Ge:H) films induced by aluminum. A series of aluminum-doped a-Ge:H films ([Al/Ge] 10-6-10-2 range) were deposited onto crystalline silicon substrates at $220^{\circ} \mathrm{C}$ by the cosputtering technique under the same nominal conditions, except for the Al/Ge concentration. Raman scattering and infrared transmission spectroscopy were used for the structural characterization. The analysis of experimental data indicates that asdeposited Al-doped a-Ge:H films having an Al relative concentration between 1 and 2 at. \% crystallize spontaneously. Aluminum contents below this range induce a partial crystallization of the films, whereas $[\mathrm{Al} / \mathrm{Ge}]>2$ at. $\%$ does not induce any crystallization. The mechanisms involved in the crystallization of these Al-doped a-Ge:H films were also investigated after thermal annealing treatments up to a temperature of $500{ }^{\circ} \mathrm{C}$. Since the films are hydrogenated, the influence of hydrogen in the crystallization process was considered in detail. The ensemble of the data leads us to associate the induced crystallization with the coordination of, and the local order around, aluminum atoms in the a-Ge:H network. A microscopic mechanism behind the low-temperature crystallization is proposed. The present research indicates that both fourfold coordinated aluminum atoms and hydrogen species are fundamental in the crystallization phenomenon: the former acting as crystallization seeds, and the latter determining the dynamics of the process.

Enquanto os efeitos da presença de Ga ou Al nos filmes de a-Ge:H são praticamente os mesmos (em termos da eficiência de dopagem e variação do bandgap óptico, por exemplo), as alterações morfológicas parecem ser mais efetivas no caso do sistema Al-Ge em função da ausência de elétrons $d$ no $\mathrm{Ga}$. Como resultado, átomos de $\mathrm{Al}$ tetraedricamente coordenados $\left(\mathrm{Al}_{4}\right)$ atuam como "sementes" de cristalização quando nas vizinhaças de sítios tetraédricos, tais que as distâncias Al-Ge sejam muito próximas àquelas verificadas no Ge cristalino. $O$ processo de cristalização, como um todo, é auxiliado pela presença de átomos de hidrogênio que permite uma maior flexibilidade da matriz amorfa e maior conectividade entre os cristalitos já formados. Em conjunto, as concentrações de $\mathrm{Al}$ e $\mathrm{H}$ e a temperatura de tratamento térmico determinam se o processo de cristalização dar-se-á gradualmente ou de forma explosiva. A Tabela 2 apresenta informações relativas à composição dos filmes investigados, bem como à forma de cristalização verificada.

Logo em seguida apresentamos alguns exemplos de resultados obtidos na investigação dos mecanismos de cristalização de filmes de a-Ge:H dopados com Al. Nas Figuras 10(a) e 10(b) temos os espectros Raman e de transmissão na região do infra-vermelho, respectivamente, de filmes sem qualquer tipo de tratamento térmico. Conforme pode ser apreciado a partir destas figuras, o sistema $\mathrm{Ge}-\mathrm{Al}$ possui uma composição específica sob a qual o processo de cristalização se dá espontaneamente [Fig. 10(a)] - em perfeito acordo como modelo fenomenológico acima proposto. Para esta faixa de concentrações de Al, os resultados de transmissão no infra-vermelho (FTIR) também apontam para um comportamento bastante peculiar: os filmes tornam-se praticamente opacos e a concentração de hidrogênio ligado é praticamente imperceptível [Fig. 
10(b)]. Dentro deste contexto, os resultados apresentados na Tabela 2 dão uma visão geral do efeito dos tratamentos térmicos sobre a cristalização dos filmes [37].

Tabela 2 - Identificação da amostra, concentração relativa $[\mathrm{Al}] /[\mathrm{Ge}]$ conforme determinada pela técnica de PIXE (particle induced xray emission), concentração de hidrogênio ligado (conforme determinado a partir de medidas de FTIR), e forma de cristalização. As amostras A e B são amostras de referência: germânio amorfo puro (a-Ge) e germânio amorfo hidrogenado não-dopado (a-Ge:H), respectivamente. Os valores indicados por estrelas foram obtidos por extrapolação e "b.s." refere-se a valores abaixo da sensibilidade da técnica experimental.

\begin{tabular}{|c|c|c|c|}
\hline Amostra & {$[\mathrm{AllGe}]$} & {$[\mathrm{H}]($ at.\%) } & Cristalização \\
\hline A & 0 & 0 & explosivo $\left(\mathrm{a} \sim 500^{\circ} \mathrm{C}\right)$ \\
\hline B & 0 & 5.7 & explosivo $\left(\mathrm{a} \sim 500^{\circ} \mathrm{C}\right)$ \\
\hline C & $5.0 \times 10^{-6}{ }^{*}$ & 4.3 & gradual \\
\hline D & $5.0 \times 10^{-5}{ }^{*}$ & 4.4 & gradual \\
\hline E & $4.5 \times 10^{-4}{ }^{*}$ & 4.0 & gradual \\
\hline F & $2.0 \times 10^{-3}$ & 4.9 & explosivo $\left(\mathrm{a} \sim 500^{\circ} \mathrm{C}\right)$ \\
\hline G & $6.3 \times 10^{-3}$ & 0.3 & explosivo $\left(\mathrm{a} \sim 500^{\circ} \mathrm{C}\right)$ \\
\hline H & $1.4 \times 10^{-2}$ & b.s. & espontâneo $\left(\mathrm{a} \sim 220^{\circ} \mathrm{C}\right)$ \\
\hline I & $1.9 \times 10^{-2}$ & b.s. & espontâneo $\left(\mathrm{a} \sim 220^{\circ} \mathrm{C}\right)$ \\
\hline J & $2.4 \times 10^{-2}$ & b.s. & explosivo $\left(\mathrm{a} \sim 500^{\circ} \mathrm{C}\right)$ \\
\hline
\end{tabular}
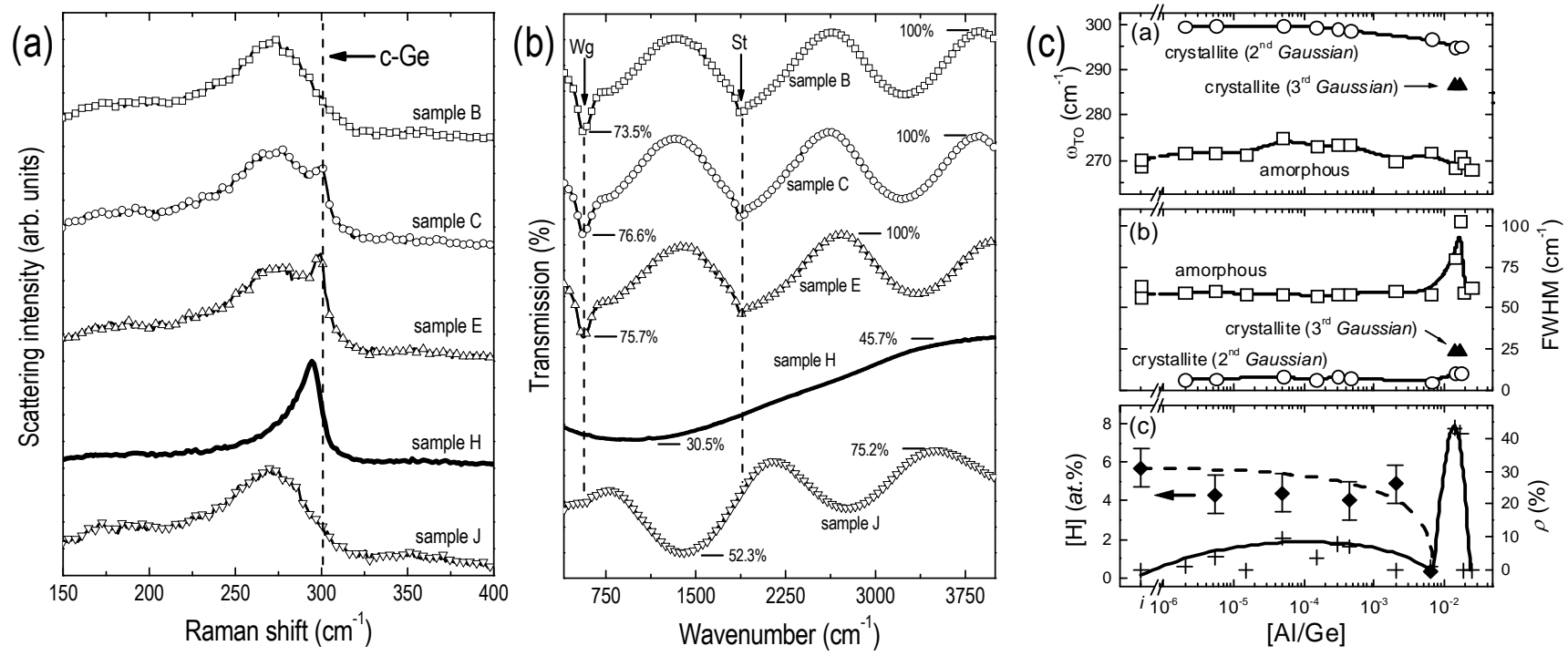

Figura 10 - Espectros de espalhamento Raman (a) e de transmissão no IR (b) para filmes de a-Ge:H com diferentes concentrações de Al. A identificação de cada espectro é a mesma apresentada na Tabela 2. Os espectros referem-se a amostras conforme depositadas, i.e., sem qualquer tipo de tratamento pós-deposição. Em (c) temos as seguintes informações: posição dos modos Raman ( cristalina de cada amostra.

A Figura 10(c), por sua vez, apresenta uma espécie de resumo acerca das informações composicionais dos filmes e respectivas características de cristalização. Nesta figura temos representados: a posição dos sinais de espalhamento Raman, a largura à meia altura destes, a concentração de hidrogênio, e a fração cristalina das amostras (conforme determinado a partir da razão entre os modos vibracionais correspondentes). A partir 
destes resultados - todos relativos a amostras conforme depositadas - fica evidente a dependência da [Al] sobre: a desordem presente nos filmes (associada à posição e à largura dos sinais Raman), a concentração de átomos de hidrogênio, e cristalização das amostras.

Além de interessante (e complexo), o estudo dos mecanismos de cristalização de filmes de a-Ge devido à presença de alumínio deu origem a trabalhos complementares envolvendo: filmes de a-Ge e Al com diferentes espessuras [39], diferentes composições e/ou substratos e diferentes condições de tratamento térmico $[40,41]$ - ver quadros a seguir.

\section{Annealing crystallization of a-Ge/Al/Si and a-Ge/Si thin films \\ F. Fajardo, A.R. Zanatta, and I. Chambouleyron, physica status solidi (b) 242, 1906 (2005)}

Abstract - This work describes the temperature-induced crystallization of amorphous $\mathrm{Ge}(\mathrm{a}-\mathrm{Ge})$ as a function of the thickness of the a-Ge films (in the 12-2600 nm range), which were deposited both onto c-Si substrates and c-Si substrates covered with aluminium. After deposition, the samples were submitted to cumulative thermal annealing treatments. It is shown that the temperature of crystallization depends on the thickness of the a-Ge films and to the presence (or not) of the Al layer. For an annealing temperature (Ta) of $\sim 700^{\circ} \mathrm{C}$, for example, the Raman spectra of films thinner than $\sim 1000 \mathrm{~nm}$ and deposited onto c-Si substrates are completely dominated by the sharp phonon mode of crystalline Si. Films with thicknesses equal to 300,1000 and $2600 \mathrm{~nm}$, deposited onto Al/c-Si, and treated at $\mathrm{Ta}=600{ }^{\circ} \mathrm{C}$, on the other hand, clearly display two additional peaks at 405 and $490 \mathrm{~cm}^{-1}$. They correspond to the Raman modes of Si-Ge and Si-Si modes, suggesting the formation of a SiGe alloy during the thermal anneal of the films.

\section{Annealing effects on crystallized Al-doped a-Ge:H thin films}

F. Fajardo, A.R. Zanatta, and I. Chambouleyron, physica status solidi (c) 2, 3750 (2005)

Abstract - Annealing effects on crystallized aluminum doped hydrogenated amorphous germanium (a-Ge:H) thin films have been studied by Raman spectroscopy, as a function of Al concentration ([Al/Ge] 10-6-10-2 range). All the as-deposited Al-doped a-Ge:H samples with $[\mathrm{A} / \mathrm{Ge}]<1.3$ at\% possess a Raman spectra that includes the signal given by the amorphous phase and a shoulder at around $300 \mathrm{~cm}^{-1}$, that evolves with increasing impurity content, to a well defined peak, corresponding to the contribution of the TO vibration of crystallized $\mathrm{Ge}$. The scattering intensity of samples having $1.4 \leq[\mathrm{Al} / \mathrm{Ge}] \leq 1.8$ at\% is dominated by the c-Ge TO vibration. Aluminum concentrations above $[\mathrm{Al} / \mathrm{Ge}]>1.8$ at\% do not indicate crystallization of a-Ge:H films to levels detectable by Raman spectroscopy. An abrupt crystallization was observed to occur after annealing at $\mathrm{Ta} \sim 500{ }^{\circ} \mathrm{C}$ for all the range of the Al-doped samples, including the intrinsic one. These results and the comparison with data of the local order and coordination of $\mathrm{Ga}$ atoms into the a-Ge:H network, suggest that Al-induced crystallization originates from fourfold coordinated aluminum atoms that act as crystallization seeds. These seeds have only small influence on the abrupt crystallization of Al doped a-Ge:H films due to annealing treatments.

\footnotetext{
Aluminum-induced nanocrystalline germanium formation at low temperatures

L.R. Muniz, C.T.M. Ribeiro, A.R. Zanatta, and I. Chambouleyron, Journal of Physics: Condensed Matter 19, 076206 (2007)

Abstract - The present work contributes to establishing the role of hydrogenation and of the substrates in the aluminum-induced crystallization process of amorphous germanium layers. For such a purpose, four series of a-Ge(Al) samples, deposited under identical nominal conditions, were studied: hydrogenated samples, $\mathrm{H}$-free samples, and samples deposited on crystalline silicon and on glass substrates, respectively. On purpose, the impurity concentration was kept at a doping level $\left(10^{-5}<[\mathrm{Al} / \mathrm{Ge}]<2 \times 10^{-3}\right)$. Furthermore, the films were submitted to isochronal cumulative thermal annealing in the $200-550^{\circ} \mathrm{C}$ range. Raman scattering spectroscopy was used to characterize the crystallization process. The role of Al impurity as a precursor seed for the crystallization of a-Ge:H has been clearly established, confirming that the metal-induced crystallization (MIC) phenomenon occurs at an atomic level. Moreover, it has been found that hydrogenation and the periodic nature of the substrate play a fundamental role in the appearance of crystal seeds at low temperatures. The evolution of crystallization with annealing temperature and the analysis of the distribution of crystallite sizes indicate that the formation of crystal seeds occurs at the amorphous film-substrate interface. The importance of fourfold-coordinated aluminum as the embryo of nanocrystal formation is discussed.
} 
Parte 2 - O sistema Si-Ni

Uma evolução natural para a investigação do processo de MIC em filmes semicondutores amorfos foi a adoção de filmes de a-Si, um material que, além de grande interesse científico-tecnológico, poderia fornecer informações complementares. Em meados de 2004 teve início, então, o estudo de filmes de silício amorfo (a-Si) com concentrações de níquel desde o nível de dopagem ( 0.1 at.\%) até a formação de ligas ( 10 at.\%). À semelhança dos trabalhos realizados até então no LFF, os filmes foram preparados pela técnica de rf sputtering e a inserção controlada de Ni era feita durante a deposição - uma metodologia francamente distinta daquela usualmente adotada na literatura. Da mesma forma, os filmes de SiNi foram investigados por intermédio de diferentes técnicas experimentais e sistematicamente submetidos a tratamentos térmicos controlados. Todo 0 trabalho realizado nesta área deu origem a uma Dissertação de Mestrado [42], bem como a algumas publicações internacionais. A mais completa destas, e que trata especificamente do fenômeno de MIC em filmes de a-Si foi publicada em 2006 [43] - ver quadro a seguir.

\section{Metal-induced nanocrystalline structures in Ni-containing amorphous silicon thin films}

F.A. Ferri, A.R. Zanatta, and I. Chambouleyron, Journal of Applied Physics 100, 094311 (2006)

Abstract - The mechanisms of silicon nanocrystal structure formation in amorphous $\mathrm{Si}$ films have been studied for a relative $\mathrm{Ni}$ impurity content varying between 0.1 and 10 at. \%, i.e., from a Ni doping range to the Si-Ni alloy phase. The films, deposited by the cosputtering technique at $200^{\circ} \mathrm{C}$, were submitted to isochronal $(15 \mathrm{~min})$ annealing cycles up to $800{ }^{\circ} \mathrm{C}$. Four different substrates were used to deposit the studied films: crystalline (c-) quartz, c-Si, c-Ge, and glass. Both the two orders of magnitude impurity concentration range variation and the very short annealing times were selected on purpose to investigate the first steps of the mechanism leading to the appearance of crystal seeds. The conclusions of this work are the following: (a) Ni impurity induces the low-temperature crystallization of amorphous silicon; (b) the NiSi2 silicide phase mediates, at the surface or in the bulk of the film, the crystallization process; and (c) the onset of crystallization and the crystalline fraction of the samples at each temperature depend not only on the $\mathrm{Ni}$ impurity concentration, but also on the nature of the substrate.

$\mathrm{Na}$ área de MIC, um dos grandes diferenciais dos trabalhos realizados no LFF refere-se à utilização de sistemas homogêneos (e não de filmes multi-camadas) e, principalmente, pelo controle absoluto sobre a composição dos mesmos. Tais aspectos são possíveis apenas graças à técnica de if sputtering ou, mais precisamente, rf cosputtering. Desta maneira podemos ter acesso aos mecanismos de cristalização em função da presença de impurezas metálicas, homogeneamente distribuídas, em filmes semicondutores amorfos. A Figura 11 ilustra a concentração de níquel em filmes de a-Si a partir da variação da área relativa de Ni metálico durante as deposições por if sputtering.

Ao contrário dos filmes de a-Ge:H dopados com Al, os filmes de a-Si contendo Ni não apresentam cristalização espontânea. Por outro lado, tanto a concentração de Ni quanto a temperatura de tratamento térmico são decisivas no processo de cristalização [43]. Tais resultados podem ser vistos na Figura 7, previamente apresentada quando da discussão do processo de cristalização induzido por espécies metálicas. A Fig. 7(b), em particular, deixa evidente que enquanto indícios de cristalização ocorrem para temperaturas $<600$ ${ }^{\circ} \mathrm{C}$ em filmes contendo $\mathrm{Ni}$, o mesmo só é verificado por volta de $\sim 700{ }^{\circ} \mathrm{C}$ no a-Si puro. Enquanto a maioria dos filmes investigados apresentou cristalização uniforme, é interessante notar que, a baixíssimas concentrações, 0 processo de cristalização dos filmes de a-Si é limitado pela presença de átomos de Ni. Este aspecto pode ser 
apreciado na Figura 12, onde temos representada uma micro-fotografia da superfície de um filme de a-Si contendo $\mathrm{Ni} \sim 0.1$ at.\% e a sua correspondente imagem Raman, ambas após tratamento a $600{ }^{\circ} \mathrm{C}$.

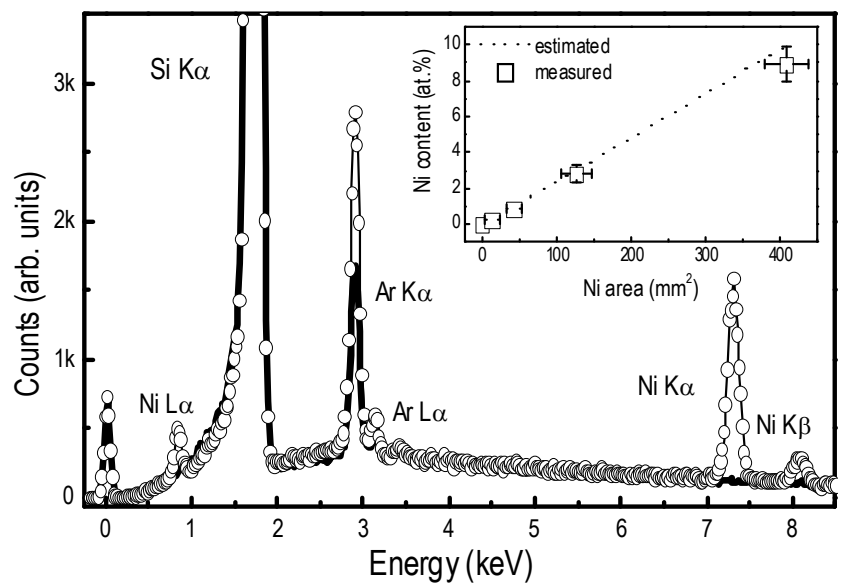

Figura 11 - Espectros de EDX (energy dispersive x-ray) de um filme de a-Si puro (linha sólida) e de um filme de a-Si contendo Ni (símbolos). Os filmes foram preparados pela técnica de if sputtering a partir de alvos com diferentes áreas de Ni metálico. A relação entre a concentração de Ni (conforme obtida por EDX) e a área do alvo pode ser vista no insert. As principais linhas de emissão de raios-x estão indicadas na figura.

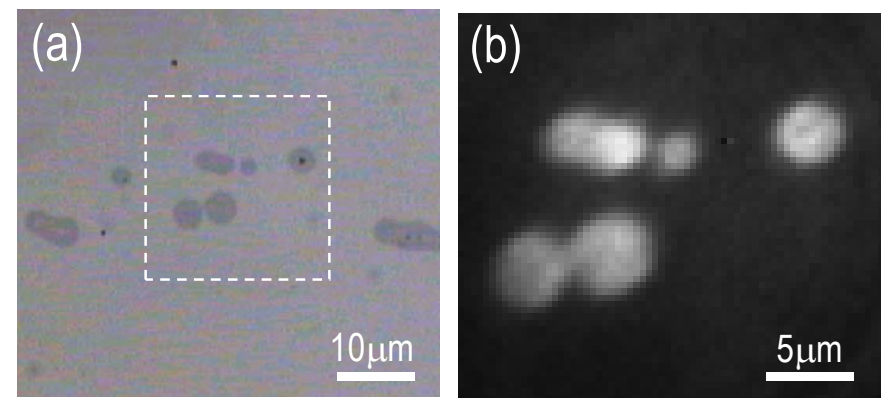

Figura 12 - (a) Micrografia óptica e (b) correspondente imagem Raman da superfície de um filme de a-Si contendo 0.1 at.\% de Ni, após tratamento térmico a $600{ }^{\circ} \mathrm{C}$. A imagem Raman foi obtida a partir da intensidade de luz espalhada em $\sim 520 \mathrm{~cm}^{-1}$ (devida a cristais de Si) e permite avaliar a distribuição espacial das regiões cristalizadas.

Outra característica peculiar do sistema $\mathrm{Si}-\mathrm{Ni}$ foi o surgimento do di-siliceto de níquel $\mathrm{NiSi}_{2}$ à medida que os tratamentos térmicos eram realizados a maiores temperaturas. A presença desta fase é evidente apenas a altas concentrações de $\mathrm{Ni} \mathrm{e}$, muito embora não seja detectada para [Ni] < 3 at.\%, certamente atua como agente nucleador do processo de cristalização do Si. A altas concentrações de Ni e após tratamentos térmicos acima de $800{ }^{\circ} \mathrm{C}$, há uma espécie de separação entre as componentes Si-Si e Si-Ni devido ao desenvolvimento do $\mathrm{NiSi}_{2}$ resultando em uma diminuição do stress presente nos filmes. Este efeito foi investigado em detalhe, ainda com o auxílio da técnica de espectroscopia Raman, e foi reportado em 2007 [44] - ver quadro a seguir.

Extraída da referência 44, a Figura 13 apresenta a evolução dos espectros Raman de filmes de Si (puro, $[\mathrm{Ni}]=1$ at. \%, [Ni] = 10 at.\%) após tratamentos térmicos a diferentes temperaturas. Além de fornecer uma estimativa para a fração cristalina dos filmes, a análise detalhada dos espectros Raman permite extrair informações acerca do stress presente nas mesmas. Este é um procedimento amplamente utilizado na indústria 
micro-eletrônica, tal que o stress presente em filmes de silício está associado à frequência do modo vibracional TO (transverse optical) devido a ligações Si-Si mediante a seguinte relação [45]:

$$
\sigma(G P a) \approx-0.19 \Delta \omega\left(\mathrm{cm}^{-1}\right)
$$

Muito do stress presente nos filmes considerados deve-se à sua deposição sobre substratos de quartzo cristalino (com parâmetro de rede e coeficiente de expansão térmica bastante distintos do c-Si). Contudo, a concentração de Ni e a realização de tratamentos térmicos a temperaturas crescentes também contribuem para o efeito. Mais especificamente: (a) com uma fração cristalina de $\sim 50 \%$, o stress compressivo dos filmes sem níquel é de $~ 0.25 \mathrm{GPa}$ (e é, essencialmente, de caráter térmico) em contraste com os $\sim 1 \mathrm{GPa}$ de stress presente nos filmes contendo $\mathrm{Ni}$; (b) valores de stress da ordem de 1-1.5 GPa, aparentemente, limitam a fração cristalina a 50\%; (c) o tratamento térmico a altas temperaturas reduz o stress apenas nos filmes contendo níquel - o que é atribuído ao surgimento de estruturas sub-microscópicas na superfície das amostras.

\section{Crystallization, stress, and stress-relieve due to nickel in amorphous silicon thin films}

A.R. Zanatta and F.A. Ferri, Journal of Applied Physics 102, 043509 (2007)

Abstract - The structural properties of amorphous silicon (a-Si) films containing 1 and 10 at. \% of nickel have been studied by Raman scattering spectroscopy. The films, typically $2 \mu \mathrm{m}$ thick, were deposited onto crystalline quartz substrates by sputtering a Si+Ni target in an atmosphere of pure argon. For comparison purposes, one Ni-free a-Si film deposited under the same experimental conditions was also investigated. After deposition the films were thermally annealed for cumulative periods of 15 min in the $200-1000{ }^{\circ} \mathrm{C}$ temperature range. The present experimental results indicate that: (1) compared to the Ni-free a-Si film, the crystallization of a-SiNio.01 and a-SiNio. 1 takes place at temperatures $\sim 20{ }^{\circ} \mathrm{C}$ lower; (2) allied to the thermal treatments, the presence of $\mathrm{Ni}$ also affects the stress present in the a-Si films; (3) the partial crystallization of the Ni-free Si film increases its original compressive (thermal) stress up to $\sim 1$ GPa; and (4) thermal annealing at temperatures higher than $800{ }^{\circ} \mathrm{C}$ induce a stress-relieve in the Ni-containing Si films, which is tentatively attributed to the development of nanostructured features on the surface of the samples.
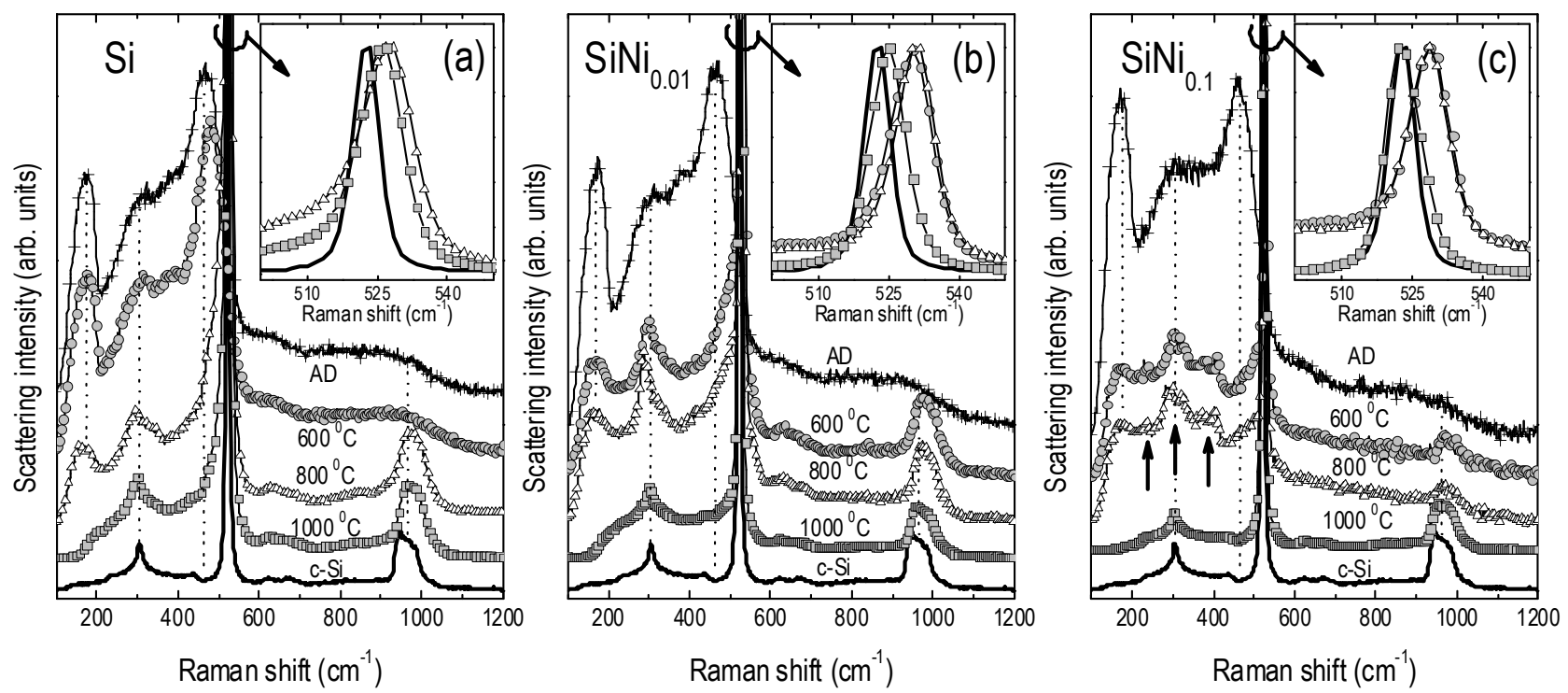

Figura 13 - Espectros Raman de filmes de silício com diferentes concentrações de Ni [(a) 0 at.\%, (b) 1 at\%, (c) 10 at.\%], conforme depositados (AD) e após tratamentos térmicos a 600,800 e $1000^{\circ} \mathrm{C}$. O espectro de uma amostra de Si cristalino é também mostrado para fins comparativos. Em destaque, nos inserts, vemos a posição do modo Raman principal (TO- transverse optical) que pode ser associado ao stress presente nos filmes. 
Grande parte desta discussão pode ser melhor apreciada com o auxílio da Figura 14, onde temos representadas, em função da temperatura de tratamento térmico, as seguintes quantidades: fração cristalina $\left(X_{F}\right)$, largura do modo vibracional transverso óptico $\left(\Gamma_{\text {то }}\right)$, variação na frequência do modo TO, e stress compressivo associado $(\sigma)$.

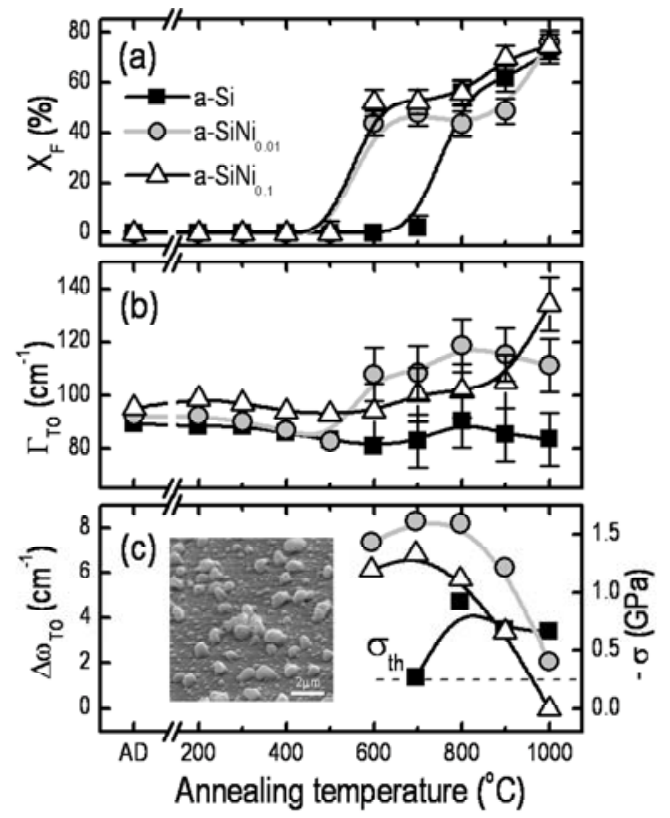

Figura 14 - (a) Fração cristalina $X_{F}$, conforme determinada a partir da análise dos espectros Raman, (b) largura do modo vibracional TO (transverse optical) em $\sim 520 \mathrm{~cm}^{-1}$, e (c) variação na frequência do modo TO ( $\Delta \omega$ To $=$ (filime - (refererncia) e respectivo stress compressivo $(-\sigma)$ de filmes de Si(Ni) em função da temperatura de tratamento térmico. Uma micrografia obtida por microscopia eletrônica de varredura ilustrando a superfície do filme contendo 10 at.\% de Ni, após tratamento a $800{ }^{\circ} \mathrm{C}$, é apresentada em (c). 0 stress térmico $\left(\sigma_{\text {th }}=-0.26 \mathrm{GPa}\right.$ ) estimado para filmes de a-Si depositado a $200^{\circ} \mathrm{C}$ está representado mediante a linha horizontal em (c).

0 mecanismo de cristalização induzida por espécies metálicas (MIC) também foi investigado quanto à influência da espessura dos filmes. Enquanto nos trabalhos anteriores as amostras de $\mathrm{Si}(\mathrm{Ni})$ apresentavam espessuras da ordem de $2 \mu \mathrm{m}$, neste caso foram considerados filmes com 10,30,100,300, 1000, e $3000 \mathrm{~nm}$ [46] - ver quadro a seguir. A fim de limitar a complexidade do problema, foram considerados apenas dois casos: filmes de a-Si puros e contendo 1 at. $\%$ de $\mathrm{Ni}$.

A Figura 15 ilustra os principais resultados obtidos, os quais podem ser sintetizados da seguinte maneira: (1) independentemente da espessura, quando comparados aos filmes de a-Si puro, os filmes de SiNi cristalizam a temperaturas cerca de $100{ }^{\circ} \mathrm{C}$ menor; (2) a mínima temperatura necessária para cristalizar os filmes de $3000 \mathrm{~nm}$ (tanto puros quanto contendo $\mathrm{Ni}$ ), é $\sim 100{ }^{\circ} \mathrm{C}$ maior que aquela verificada nos filmes mais finos; (3) segundo as condições experimentais adotadas (filmes de a-Si sujeitos a tratamentos térmicos cumulativos, de $15 \mathrm{~min}$ cada, até $1000^{\circ} \mathrm{C}$ ), não há conexão aparente entre a (des)ordem estrutural e a temperatura mínima necessária para induzir cristalização - em franco contraste com alguns modelos teóricos 
existentes [47]; e (4) os resultados são consistentes com a idéia de que a fase $\mathrm{NiSi}_{2}$ influencia a formação de cristalitos de silício, quer seja atuando como centros de nucleação ou reduzindo a barreira energética para tal. Por fim, é importante ressaltar que, devido à sua condição de não-equilíbrio, os mecanismos envolvidos no processo de cristalização de filmes semicondutores amorfos não é único, e depende estritamente de vários detalhes experimentais (sistemas multi-camadas ou dopados, tipo e concentração de impurezas, condições de tratamento térmico, métodos de caracterização, etc.). Não obstante todas estas limitações, o estudo dos mecanismos de cristalização destes materiais (qualquer que seja o método considerado) é de vital importância para o desenvolvimento de novos materiais e/ou dispositivos.

\section{Influence of film thickness on the crystallization of Ni-doped amorphous silicon samples}

F.A. Ferri and A.R. Zanatta, Journal of Applied Physics 104, 013534 (2008)

Abstract - This work reports on the crystallization of amorphous silicon (a-Si) films doped with 1 at. \% of nickel. The films, with thicknesses ranging from 10 to $3000 \mathrm{~nm}$, were deposited using the cosputtering method onto crystalline quartz substrates. In order to investigate the crystallization mechanism in detail, a series of undoped a-Si films prepared under the same deposition conditions were also studied. After deposition, all a-Si films were submitted to isochronal thermal annealing treatments up to $1000{ }^{\circ} \mathrm{C}$ and analyzed by Raman scattering spectroscopy. Based on the present experimental results, it is possible to state that (a) when compared to the undoped a-Si films, those containing 1 at. $\%$ of Ni crystallize at temperatures $\sim 100{ }^{\circ} \mathrm{C}$ lower, and that (b) the film thickness influences the temperature of crystallization that, in principle, tends to be lower in films thinner than $1000 \mathrm{~nm}$. The possible reasons associated to these experimental observations are presented and discussed in view of some experimental and thermodynamic aspects involved in the formation of ordered Si-Si bonds and in the development of Ni-silicide phases.
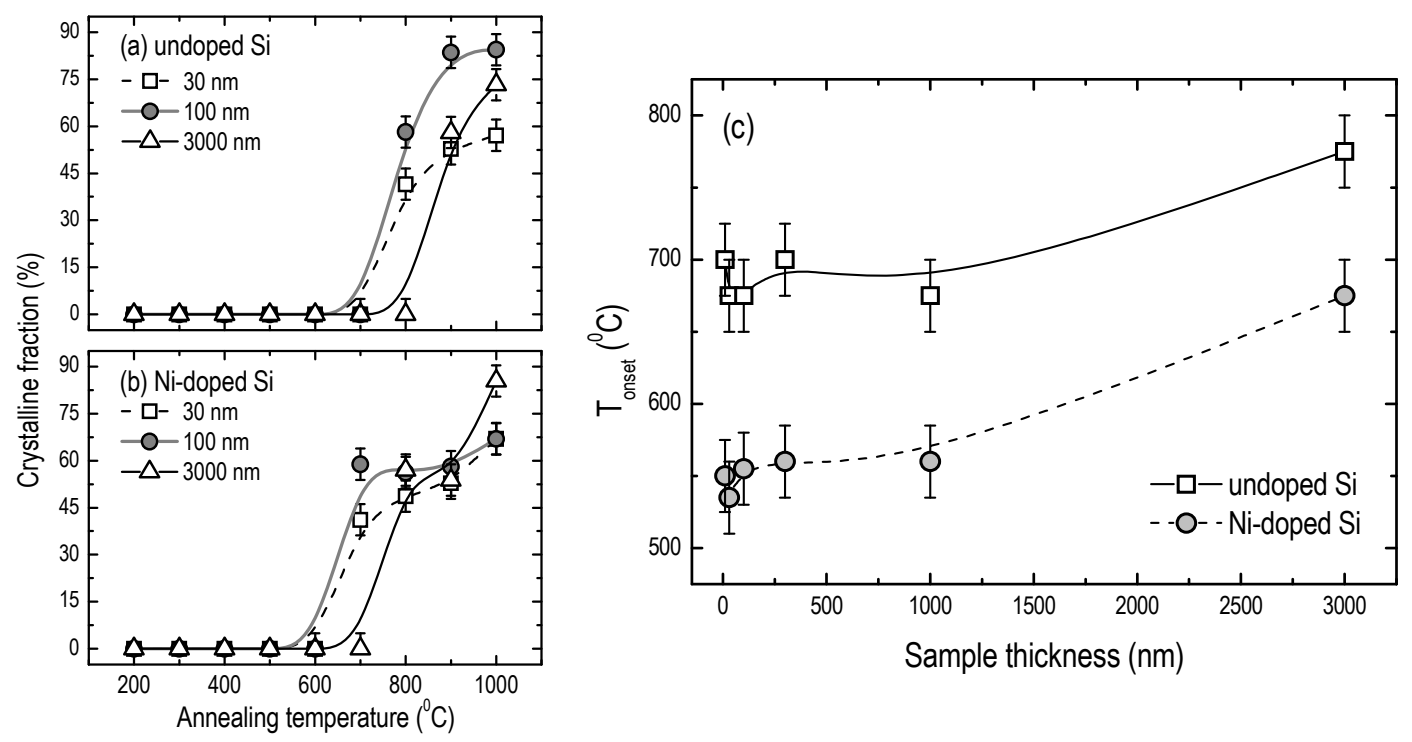

Figura 15 - Fração cristalina, conforme determinada a partir de espectroscopia Raman, para filmes de Si [(a) puros e (b) dopados com 1 at.\% de Ni] com diferentes espessuras, em função da temperatura de tratamento térmico. Em (c) temos representada a temperatura de limiar de cristalização para filmes de $\mathrm{Si}$ (puros e dopados com Ni), em função da espessura.

No regime de concentrações de impurezas metálicas relativamente altas, e após tratamentos térmicos a temperaturas maiores que $\sim 500{ }^{\circ} \mathrm{C}$, além do fenômeno de $\mathrm{MIC}$, pudemos observar o surgimento da fase $\mathrm{NiSi}_{2}$ nos filmes de SiNi. O desenvolvimento de silicetos também foi verificado em filmes de a-Si contendo Fe e Mn. Nestes casos, no entanto, não ocorre o processo de cristalização induzida por espécies metálicas, em uma 
clara alusão aos aspectos químicos envolvidos no processo. Diga-se de passagem, em alguns casos, uma grande concentração de metal parece restringir o mecanismo de cristalização dos filmes de a-Si.

As figuras a seguir (Figura 16 e 17) ilustram alguns dos resultados obtidos em filmes de a-Si, preparados pela técnica de if sputtering, com diferentes concentrações de $\mathrm{Mn}$, Fe e Ni.

Parte 3 - Outros sistemas
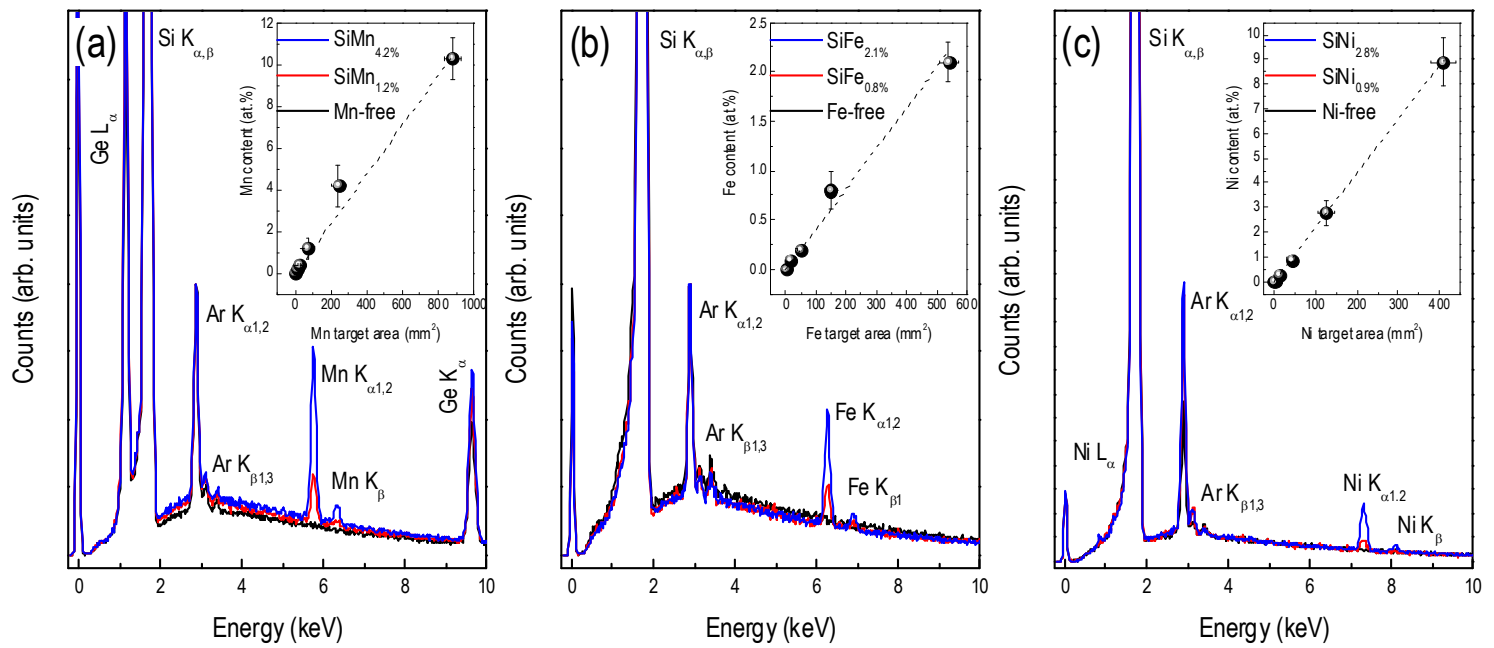

Figura 16 - Curvas de EDX (energy dispersive x-ray) de filmes de a-Si contendo: (a) Mn, (b) Fe, e (c) Ni. Os filmes foram preparados pela técnica de if sputtering a partir de diferentes áreas relativas (metal-silício), e as suas concentrações estão indicadas nos inserts. Exceto pelos filmes de SiMn, depositados sobre c-Ge, todos os demais foram depositados sobre substratos de c-Si.
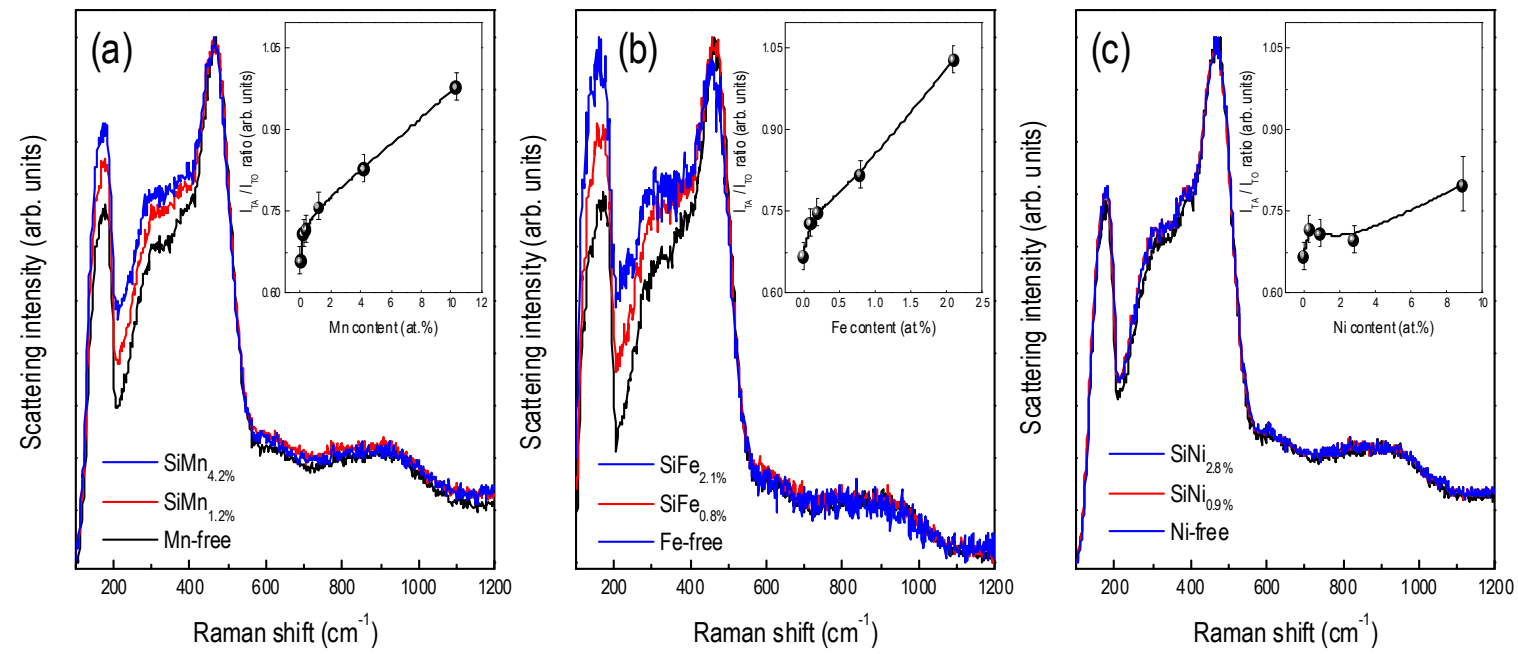

Figura 17 - Espectros de espalhamento Raman de filmes de a-Si contendo diferentes concentrações de: (a) Mn, (b) Fe, e (c) Ni, conforme indicado nas figuras. Os inserts contém informações relativas à desordem estrutural (razão I IA / ITo) em função da concentração de espécies metálicas.

Este é um estudo ainda em andamento, mas as informações presentes nas figuras deixam evidente que: (1) a técnica de rf sputtering tornou possível o preparo de filmes de a-Si com a inserção controlada de Mn, Fe, e 
$\mathrm{Ni}$; (2) conforme apontado pela razão $\mathrm{I}_{\mathrm{TO}} / \mathrm{I}_{\mathrm{TA}}$ (que é proporcional à desordem estrutural presente nos filmes de a-Si $[3,48]$ ), e exceto para o sistema $\mathrm{SiNi}$, a presença de impurezas metálicas aumenta drasticamente a desordem dos filmes; (3) o surgimento de contribuições devidas à presença de silicetos metálicos ocorre apenas após tratamento a temperaturas maiores que $\sim 600{ }^{\circ} \mathrm{C}$; e (4) sob condições semelhantes (de composição atômica e de tratamentos térmicos) a formação dos silicetos de $\mathrm{Mn}\left(\mathrm{MnSi}_{1.7}\right)$ e de $\mathrm{Fe}\left(\mathrm{FeSi}_{2}\right)$ parece ser muito mais efetiva que a de $\mathrm{Ni}\left(\mathrm{NiSi}_{2}\right)$ - Figura 18. A presença quase imperceptível do $\mathrm{NiSi}_{2}$, aliada à baixa desordem estrutural promovida pela inserção de Ni, pode estar por trás do processo de MIC observado apenas nos filmes de SiNi (Figura 7). A propósito, a análise detalhada dos espectros Raman dos filmes de SiMn e de SiFe (não apresentado) deixa claro que as suas frações cristalinas são inversamente proporcionais a [Mn] e [Fe].
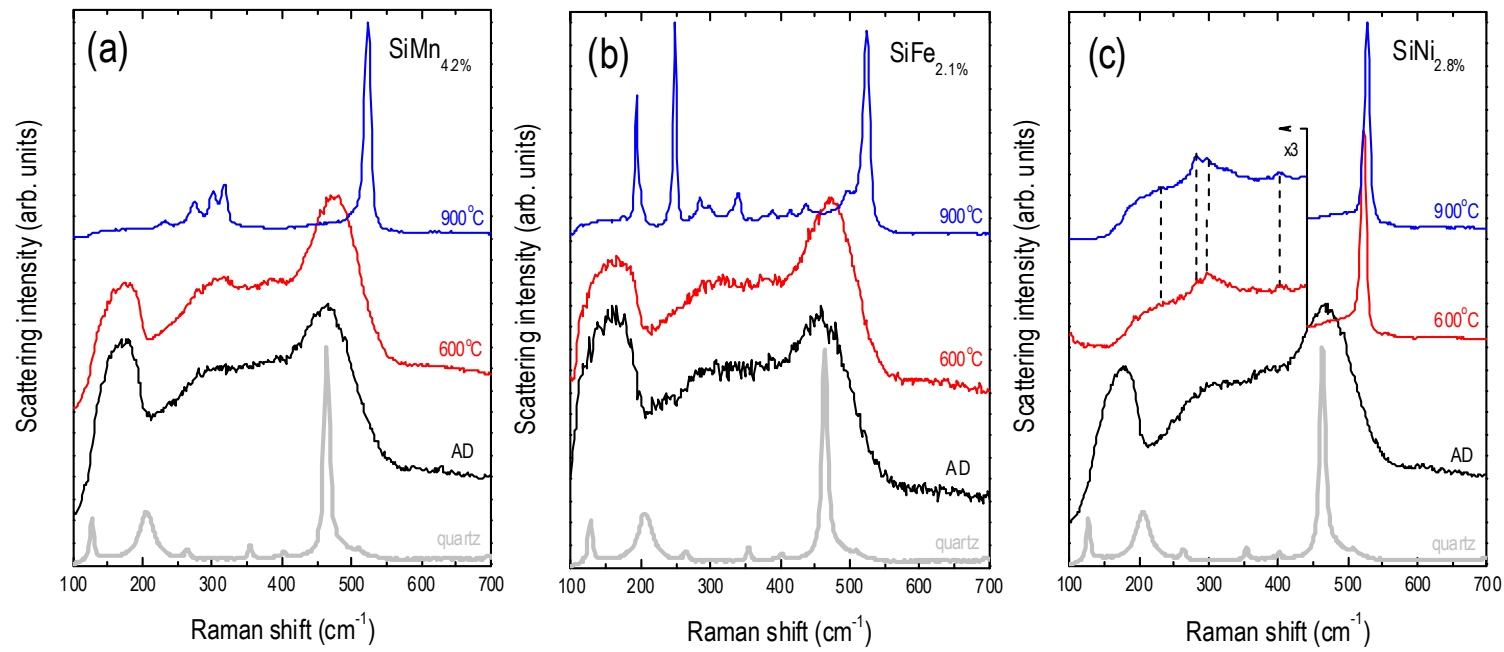

Figura 18 - Espectros de espalhamento Raman, em função da temperatura de tratamento térmico, de filmes de a-Si contendo: (a) $[\mathrm{Mn}]=4.2$ at.\%, (b) $[\mathrm{Fe}]=2.1 \mathrm{at} . \%, \mathrm{e}(\mathrm{c})[\mathrm{Ni}]=2.8$ at.\%. Os filmes foram depositados sobre substratos de quartzo cristalino, cujo espectro Raman também é apresentado. Após tratamento a $900^{\circ} \mathrm{C}$, vemos claramente o surgimento de novos modos vibracionais que são associados à presença dos silicetos: (a) $\mathrm{MnSi}_{1.7}$, (b) $\mathrm{FeSi}_{2}$, e (c) $\mathrm{NiSi}_{2}$.

O mecanismo de MIC aliado ao desenvolvimento de uma nova fase foi observado, no entanto, em filmes de Ge com concentrações crescentes de Mn [49]. A fim de ilustrar o fato, a Figura 19 apresenta os espectros Raman de alguns dos filmes investigados, bem como a fração cristalina dos mesmos após a realização de tratamentos térmicos até $500^{\circ} \mathrm{C}$. 

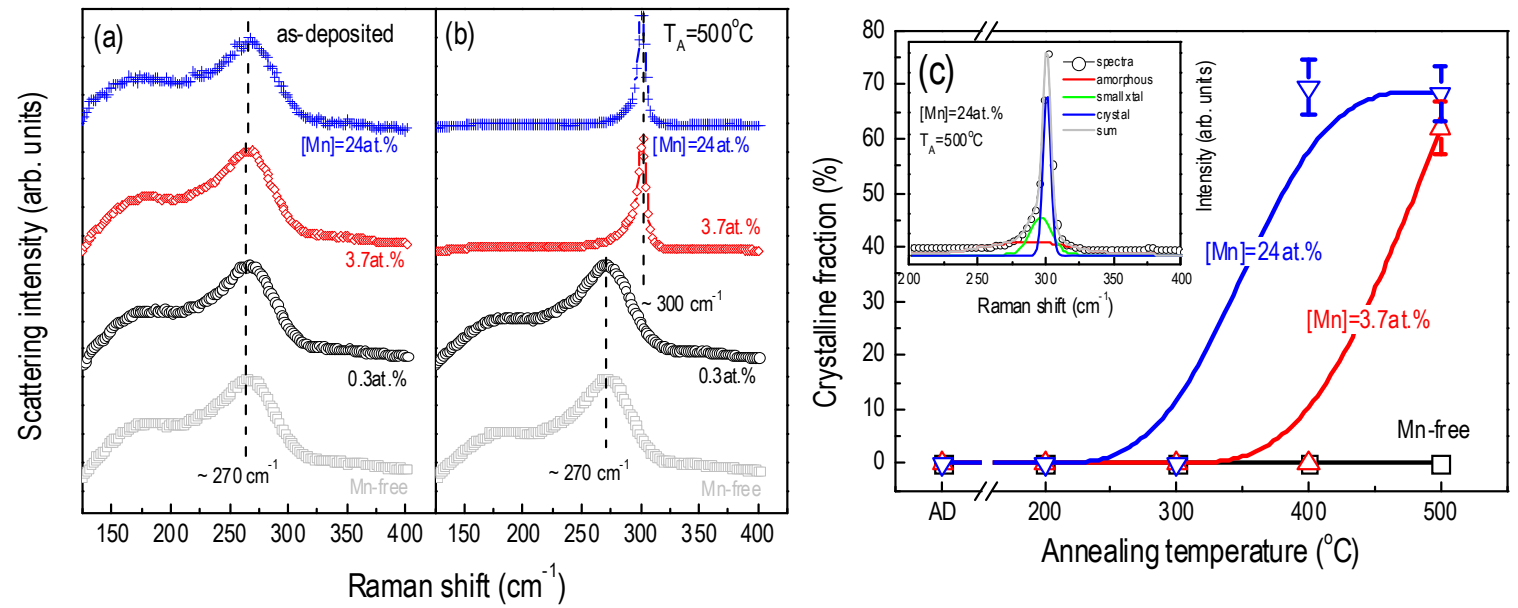

Figura 19 - Espectros de espalhamento Raman, de filmes de Ge com diferentes concentrações de Mn: (a) conforme depositados (AD- as-deposited), e (b) após tratamento térmico a $500{ }^{\circ} \mathrm{C}$. Em (c) temos a fração cristalina (conforme determinada a partir da análise dos espectros Raman - ver insert) em função da temperatura de tratamento térmico, para filmes de Ge: puro (Mn-free) e contendo 3.7 e 24 at. $\%$ de $\mathrm{Mn}$.

\section{Cristalização induzida por radiação laser LIC (laser induced crystallization)}

Parte 1 - Cristalização homogênea

O primeiro trabalho envolvendo a cristalização de filmes finos semicondutores por intermédio de radiação laser, foi feito em meados de 1998 [50] - ver quadro a seguir. Na realidade, o estudo pretendia explorar a influência de diferentes tipos de tratamento sobre as propriedades luminescentes de filmes de a-Si:H dopado com íons $\mathrm{Er}^{3+}$. O estudo levou em consideração tratamentos térmicos convencionais $\left(100-600{ }^{\circ} \mathrm{C}\right.$, por intervalos cumulativos de $15 \mathrm{~min}$ ) e aqueles envolvendo lasers de $\mathrm{Ar}^{+}$( $1 \mathrm{~W}$ de radiação contínua, em $514.5 \mathrm{~nm}$, por $\sim 30$ s) e Nd-YAG ( $500 \mathrm{~mJ} \mathrm{~cm}^{-2}$, pulsos de $10 \mathrm{~ns}$ de duração e taxa de repetição de $50 \mathrm{~Hz}$, em $532 \mathrm{~nm}$, por 3 min). Enquanto a aplicação de radiação laser efetivamente cristalizou os filmes, o mesmo não ocorreu com os tratamentos térmicos até $600^{\circ} \mathrm{C}$. Os tratamentos térmicos convencionais, por outro lado, mostraram-se muito mais eficientes na ativação dos íons $\mathrm{Er}^{3+} \mathrm{e}$ consequente melhora nas propriedades luminescentes do material (Figura 20). Como principal resultado, foi possivel atestar que os mecanismos de excitação-recombinação dos íns $\mathrm{E}^{3+}$ dependem de outros fatores que não aqueles exclusivamente determinados pela ordem atômica. Esta conclusão, no entanto, parece estar limitada ao caso do a-Si:H - conforme veremos mais à frente - e outras condições de tratamento podem render resultados comparáveis (ou melhores) àqueles obtidos pelo tratamento térmico.

\section{Optical and structural properties of laser annealed Er-doped amorphous silicon thin films}

M.J.V. Bell, L.A.O. Nunes, and A.R. Zanatta, Journal of Applied Physics 86, 701 (1999)

Abstract - Er-doped hydrogenated amorphous silicon (a-SiEr:H) thin films were deposited by cosputtering. After deposition, the samples were submitted to annealing treatments employing $\mathrm{Ar}^{+}$and Nd-YAG lasers. Thermal anneals in a temperature-controlled furnace were also performed for comparison purposes. Photoluminescence, optical absorption in the infrared energy region, and Raman spectroscopies were carried out after each annealing treatment. Based on the experimental data, some mechanisms associated with the different annealing procedures and $\mathrm{Er}^{3+}$ ion excitation are proposed and discussed. 


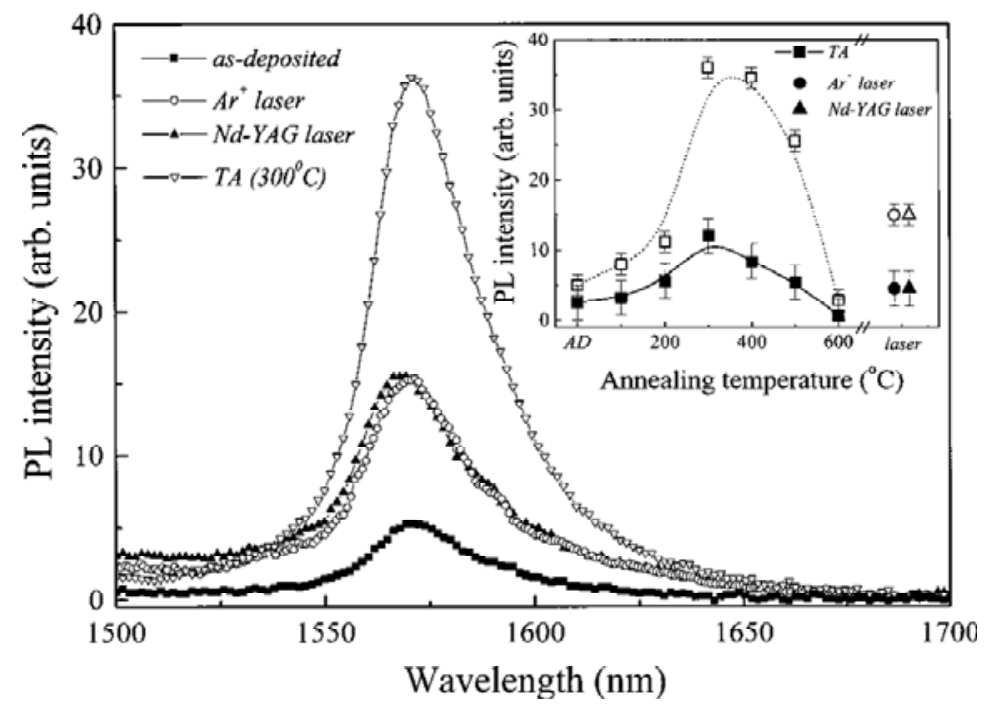

Figura 20 - Espectros de foto-luminescência de filmes de a-Si:H dopados com $\mathrm{Er}^{3+}$ e submetidos a diferentes situações: sem qualquer tratamento (as-deposited), após radiação laser ( $\mathrm{Ar}^{+} \& \mathrm{Nd}-\mathrm{YAG}$ laser), e tratado termicamente (TA) até $300{ }^{\circ} \mathrm{C}$. No insert vemos um comparativo entre as intensidades de foto-luminescência em função do tipo e temperatura de tratamento: à temperatura ambiente (símbolos preenchidos) e a $77 \mathrm{~K}$ (símbolos vazios).

Algum tempo mais tarde, investigamos a produção de filmes epitaxiais de Ge mediante a utilização da técnica de LIC. Neste caso consideramos filmes finos de a-Ge depositados sobre substratos de GaAs cristalino e os efeitos da potência da radiação laser (Nd-YAG em $532 \mathrm{~nm}$, um único pulso de $7 \mathrm{~ns}$ ) sobre os mecanismos de cristalização [51] - ver quadro a seguir. Os filmes de a-Ge foram depositados por uma técnica semelhante à de if sputtering (IBAD- ion beam assisted deposition) e investigados, principalmente, por espectroscopia Raman e microscopia eletrônica de transmissão. Este trabalho foi feito em colaboração com a UNICAMP e com o PaulDrude Institute (Berlim).

\section{Epitaxial pulsed laser crystallization of amorphous germanium on GaAs}

P.V. Santos, A. Trampert, F. Dondeo, D. Comedi, H.J. Zhu, K.H. Ploog, A.R. Zanatta, and I. Chambouleyron, Journal of Applied Physics 90, 2775 (2001)

Abstract - We have investigated the crystallization of amorphous germanium films on GaAs crystals using nanosecond laser pulses. The structure and composition of the crystallized layers is dominated by nonequilibrium effects induced by the fast cooling process following laser irradiation. Perfect epitaxial films are obtained for fluencies that completely melt the Ge film, but not the substrate. For higher fluencies, partial melting of the substrate leads to the formation of a ( $\mathrm{GaAs})_{1-\mathrm{x}} \mathrm{Ge}_{2 x}$ epitaxial alloy with a graded composition profile at the interface with the substrate. Since $\mathrm{Ge}$ and $\mathrm{GaAs}$ are thermodynamically immiscible in the solid phase, the formation of the alloy is attributed to the suppression of phase separation during the fast cooling process. Lower laser fluencies lead to polycrystalline layers with a patterned surface structure. The latter is attributed to the freeze-in of instabilities in the melt during the fast solidification process.

A técnica de LIC mostrou-se muito eficiente para a produção de camadas de Ge cristalino (Figura 21), cujas características dependem essencialmente da potência de radiação laser. Em conjunto com outras informações (espectros de reflexão resolvidos temporalmente, e análises composicionais) também foi possível inferir acerca do(s) mecanismo(s) de formação dos cristais de Ge. 


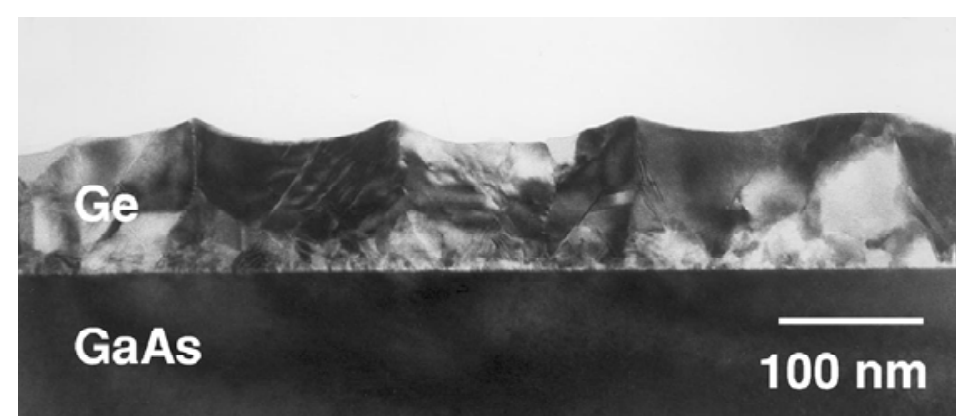

Figura 21 - Micrografia de secção transversal, obtida por transmissão de elétrons, da interface Ge/GaAs após tratamento com radiação laser. Experimentos de espalhamento Raman e de difração de elétrons confirmam que a superfície mais externa da amostra corresponde a Ge poli-cristalino. $O$ formato irregular da sua superfície deve-se à utilização de uma alta densidade de energia durante o processo de LIC.

Uma vez estabelecida a produção de filmes de Ge cristalino a partir da técnica de MIC, e tendo uma idéia geral do mecanismo de formação destes filmes, a próxima etapa consistiu em gerar um padrão regular destas estruturas cristalinas. Para tanto, era necessária a cristalização seletiva (ou laser structuring) dos filmes de aGe.

\section{Parte 2 - Cristalização seletiva ou laser structuring}

Os filmes considerados nesta etapa do trabalho foram essencialmente os mesmos do caso anterior. Apenas as condições e a geometria do sistema de LIC foi adaptada: demos uma atenção especial à densidade de energia e ao formato do feixe e, ao invés de apenas um foram utilizados dois feixes coerentes de radiação laser.

Para a efetiva confecção de padrões (sub-microscópicos) regulares é importante garantir a estabilidade mecânica de todo o sistema. Aliada à necessidade de uma alta densidade de energia para que haja a fusão do material considerado, justifica-se a utilização de radiação laser pulsada na faixa de nano-segundos. Não obstante o cuidado com todos estes detalhes, o processo está sujeito ainda aos mecanismos de transporte de calor e de re-solidificação do material. Tais aspectos foram apresentados e discutidos em detalhe em um artigo publicado em 2002 [52] - ver quadro a seguir.

\section{Laser interference structuring of a-Ge films on GaAs}

P.V. Santos, A.R. Zanatta, U. Jahn, A. Trampert, F. Dondeo, and I. Chambouleyron, Journal of Applied Physics 91, 2916 (2002)

Abstract - We have investigated the laser interference crystallization (LIC) of amorphous germanium films on (100)-oriented GaAs substrates using nanosecond laser pulses. We demonstrate that LIC can produce periodic arrays of epitaxially crystallized Ge lines on GaAs with submicrometer widths. The gratings display a surface undulation with faceted surfaces, which depends on laser fluency. The undulation is attributed to the lateral solidification process induced by the temperature gradients created during the LIC process.

A investigação foi muito bem sucedida na medida em que conseguiu gerar padrões regulares (período de $1 \mu \mathrm{m}$ ) de Ge cristalino sobre o GaAs. Da mesma forma que no trabalho anterior, algumas regiões cristalizadas pela técnica de LIC são perfeitamente epitaxiais. A sua ocorrência, no entanto, depende drasticamente da densidade de energia e uniformidade dos feixes de radiação laser. Justamente em função desta dependência, foi possivel verificar a formação de linhas de Ge cristalino com diferentes perfis (Figura 22), os quais estão 
estritamente associados às particularidades dos feixes incidentes e, principalmente, dos mecanismos de resolidificação do filme de Ge [52,53].

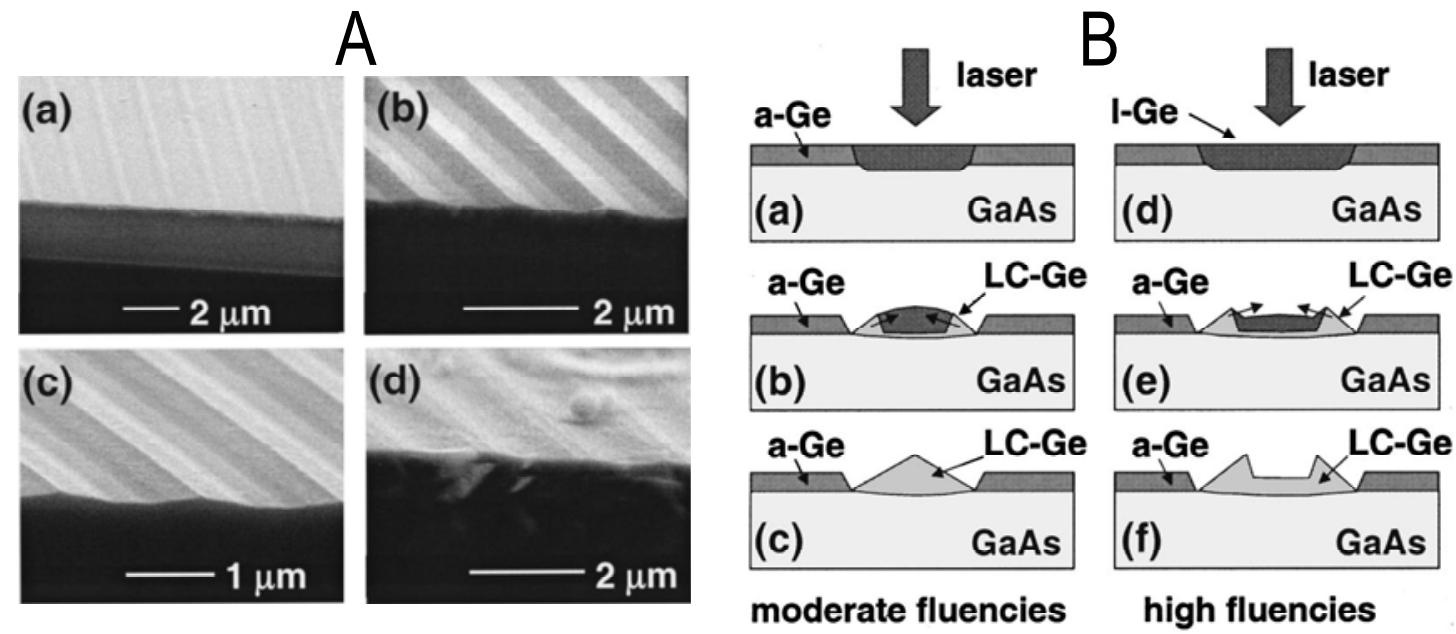

Figura 22 - A- Micrografias obtidas por microscopia eletrônica de varredura da superfície de uma amostra de a-Ge/c-GaAs sujeita à incidência de dois feixes coerentes de radiação laser $(532 \mathrm{~nm}, 7 \mathrm{~ns})$ com diferentes intensidades: (a) baixa, (b)\&(c) moderada, e (d) alta. B- Diagrama esquemático ilustrando a sequência de eventos quando do processo LIC para intensidades moderada [(a)-(c)] e alta $[(d)-(e)]$.

\section{Parte 3 - Aplicações de cristalização seletiva ou laser structuring}

A técnica de cristalização seletiva também foi utilizada, sob diferentes condições e em outros tipos de amostras, a fim de explorar a sua eventual aplicação tecnológica. Um dos primeiros estudos neste sentido considerou o emprego de filmes de nitreto de germânio amorfo (a-GeN) e a utilização de radiação laser ultravioleta $(355 \mathrm{~nm}$ ). Tal escolha levou em consideração o bandgap óptico do a-GeN (Eg 3-4 eV) de forma a maximizar a absorção de fótons pelo material e, consequentemente, tornar mais eficiente o processo de LIC. De fato, foi possível gerar um padrão regular (período de $\sim 4 \mu \mathrm{m}$ ) sobre a superfície do a-GeN (Figura 9) a qual, efetivamente, atuou como uma grade de difração. Além disto, foi possível correlacionar o processo de cristalização induzida por radiação laser e a "expulsão" de átomos de nitrogênio da rede, fazendo com que apenas ligações $\mathrm{Ge}-\mathrm{Ge}$ fossem cristalizadas com a consequente formação de uma grade de relevo. Os detalhes acerca deste estudo podem ser encontrados na referência 54 - ver quadro a seguir.

\section{Optical diffraction gratings produced by laser interference structuring of amorphous germanium-nitrogen alloys}

M. Mulato, A.R. Zanatta, D. Toet, and I. Chambouleyron, Applied Physics Letters 81, 2731 (2002)

Abstract - We use the interference of two pulsed laser beams (wavelength $=355 \mathrm{~nm}$ ) to produce an optical diffraction grating in amorphous germanium-nitrogen alloy (a-GeN). At the constructive maxima of the interference pattern, the absorption of light leads to crystallization. The crystallized region results of pure microcrystalline germanium $(\mu \mathrm{c}-\mathrm{Ge})$. An indication that $\mathrm{Ge}-\mathrm{N}$ bonds have broken and nitrogen outdiffused of the film is obtained from infrared spectroscopy and confirmed by Raman spectra. A pattern of alternating a$\mathrm{GeN}$ and $\mu \mathrm{c}-\mathrm{Ge}$ lines with a period of about $4 \mu \mathrm{m}$ acts as an optical diffraction grating due to the difference in optical properties between the two materials, and the three dimensional surface profile, caused by $\mathrm{N}_{2}$ effusion, that is formed on the sample. 
Anos mais tarde, e buscando tirar o máximo proveito das facilidades existentes no LFF, desenvolvemos uma metodologia para a geração de padrões microscópicos organizados sobre a superfície de filmes finos amorfos. A idéia é bastante simples e, baseada nos princípios da técnica de LIC, consiste em "desenhar" um padrão com o auxílio de um microscópico óptico e de um laser. Dependendo do material e das condições experimentais adotadas é possível cristalizar regiões da ordem do diâmetro do spot da radiação laser que é, geralmente, de $1 \mu \mathrm{m}$ (ver Figura 8). Além de possibilitar a geração de padrões altamente organizados, esta metodologia pode se prestar à construção de micro-dispositivos, por exemplo. Isto foi testado no LFF com filmes de a-GeN dopados com diferentes íons terra-rara [55] - ver quadro a seguir - e fez parte do programa de pós-doutoramento da Dra. Cristina Ribeiro.

\section{Laser-induced generation of micrometer-sized luminescent patterns on rare-earth-doped amorphous films}

A.R. Zanatta and C.T.M. Ribeiro, Journal of Applied Physics 96, 5977 (2004)

Abstract - Room-temperature photoluminescence has been achieved from rare-earth-doped amorphous (a-) GeN films. The samples were prepared by the radio-frequency-sputtering method, and light emission from the rare-earth (RE) centers was obtained after irradiating the films with a highly focused laser beam. As a result of this laser annealing procedure, almost circular holes with approximately $1 \mu \mathrm{m}$ diameter were produced on the surface of the a-GeN films. The area nearby these holes corresponds to crystalline $\mathrm{Ge}$ and coincides with the regions, where relatively strong RE-related luminescence takes place. These laser-annealed areas can be easily and conveniently managed in order to generate different microscopic luminescent patterns. Depending on the RE ion employed, visible and near-infrared light emission were obtained from the patterns so produced. The development of these micrometer-sized luminescent centers, as well as their probable mechanisms of excitation-recombination, will be presented and discussed. The importance of the current experimental results to future technological applications such as microdevices, for example, will also be outlined.

Como de praxe, e de modo a permitir a inserção controlada de impurezas no material, os filmes de a-GeN foram produzidos pela técnica de if sputtering. Os filmes (com espessuras da ordem de $500 \mathrm{~nm}$ ) foram dopados com aproximadamente 0.5 at.\% de $\mathrm{Er}, \mathrm{Sm}$, Pr e Ho, e os padrões microscópicos foram gerados com um laser de $\mathrm{Ar}^{+}(\mathrm{cW}, 488.0 \mathrm{~nm})$ sob uma densidade de potência igual a $\sim 2 \mathrm{~mW} \mathrm{~mm}^{-2}$.

Além de permitir a sua cristalização com radiação laser, o principal atributo dos filmes considerados é a possibilidade de produzirem luminescência. No presente caso, isto permitiria a construção de dispositivos luminescentes com dimensões microscópicas, sem a necessidade de: (a) qualquer tipo de filtragem óptica; (b) condições especiais (vácuo, altas temperaturas, substratos especiais, etc.); e (c) processos foto-litográficos. Combinados a outros tipos de materiais (e propriedades), as possibilidades são praticamente infinitas.

A Figura 23 apresenta alguns resultados do trabalho realizado acerca da micro-estruturação dos filmes de a-GeN dopados com íons terra-rara. Na figura temos representados os espectros de foto-luminescência (obtidos à temperatura ambiente) que ocorrem apenas após o processo de cristalização. Conforme pode ser visto, os sinais de luminescência são relativamente intensos e em comprimentos de onda muito bem definidos. Algumas imagens de foto-luminescência são também representadas na Fig. 23, deixando evidente a alta resolução espectral e espacial dos padrões luminescentes assim produzidos. 

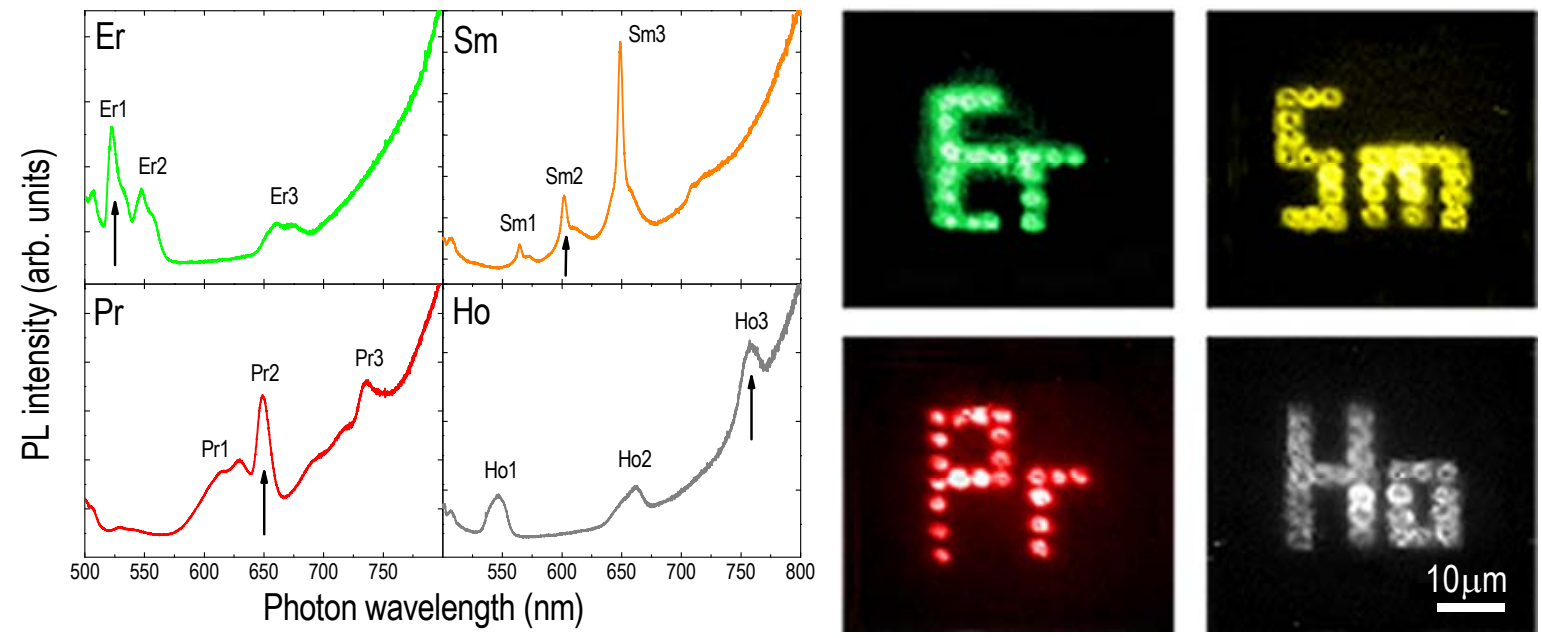

Figura 23 - (Esquerda) Espectros de foto-luminescência, obtidos à temperatura ambiente, de filmes de a-GeN dopados com Er, Sm, Pr e Ho e após o processo de cristalização induzida por radiação laser. (Direita) Imagens de foto-luminescência dos mesmos filmes evidenciando que a emissão de luz dá-se apenas nas regiões cristalizadas. 


\section{Considerações Finais}

Neste Capítulo foram apresentados, de maneira muito breve e simplista, os conceitos fundamentais associados aos mecanismos de cristalização de semicondutores amorfos. Iniciamos por uma revisão de alguns conceitos de Estados (de Agrupamento) da Matéria, o que foi seguido pela apresentação de informação mais específica acerca dos semicondutores amorfos: Estrutura Atômica e Eletrônica, Formação de Filmes Finos, e Estabilidade Térmica e Estrutural. O Capítulo discutiu, também, dois dos principais processos de transformação estrutural tipicamente empregados nos semicondutores amorfos: Cristalização Induzida por Espécies Metálicas (MICmetal induced crystallization) e Cristalização Induzida por Radiação Laser (LIC- laser induced crystallization).

O Capítulo encerra-se com a apresentação comentada de alguns dos trabalhos na área de Cristalização de Finos Finos Semicondutores (essencialmente, MIC e LIC), realizados no Lab. de Filmes Finos (IFSC- USP). Dentre os sistemas considerados valem destacar: (a) filmes de a-Ge:H dopados com Al ([Al]/[Ge] 10-6-10-2), tratados termicamente até $500{ }^{\circ} \mathrm{C}$; (b) filmes de a-Si com concentrações de Ni desde o nível de dopagem $(\sim$ 0.01 at.\%) até a formação de ligas-silicetos ( $\mathrm{Ni} \sim 10$ at.\%), submetidos a tratamentos até $\sim 1000{ }^{\circ} \mathrm{C}$; e (c) outras combinações igualmente interessantes onde o fenômeno de MIC pode (Ge+Mn), ou não (SiMn e SiFe), se manifestar mas, que sempre são acompanhadas pela formação de novas fases $\left(\mathrm{Mn}_{5} \mathrm{Ge}_{3}, \mathrm{MnSi}_{1.7}\right.$ e $\left.\mathrm{FeSi}_{2}\right)$. Em todos os casos, a técnica de espectroscopia Raman foi largamente utilizada para investigação. Além de nãodestrutiva, rápida e altamente sensível, esta técnica possibilita a realização de medidas com grande resolução espacial $(\sim 1 \mu \mathrm{m})$, e a sua análise meticulosa permite acessar informações tais como: fração cristalina, grau de (des-)ordem do sistema, quantificação (e tipo) de stress presente, etc.

Em praticamente todos os sistemas investigados existem evidências de que o processo de MIC se dá a nível atômico-molecular e é altamente influenciado pelas características químicas dos metais e dos semicondutores considerados - nem sempre mediados (e/ou determinados) pela presença de uma nova fase. Esta situação pode ser verificada quando do estudo das combinações Si+Mn e Ge+Mn (preparados e submetidos a tratamentos térmicos muito semelhantes) onde, a presença de $\mathrm{MnSi}_{1.7}$ não garantiu o processo de MIC. O mesmo aplica-se ao sistema Si+Fe onde, para as condições adotadas, não foi possível verificar qualquer influência do Fe sobre o mecanismo de cristalização dos filmes.

Como característica fundamental dos trabalhos realizados no LFF e que são, francamente, distintos da abordagem tradicionalmente dada aos estudos de MIC é importante salientar: (1) a investigação de filmes codepositados tal que as espécies semicondutor+metal não estão "separadas" como no caso de sistemas multicamadas mas, sim, distribuídas homogeneamente; (2) a realização de estudos sistemáticos no que diz respeito ao preparo, condições de tratamento pós-deposição, e caracterizações (com ênfase para a determinação da composição dos filmes); e (3) os tratamentos térmicos sempre foram realizados sob condições de alto controle (atmosfera e temperatura) e por intervalos relativamente curtos (15 min).

O tema de cristalização induzida por radiação laser foi dividido em três partes principais: cristalização homogênea, laser structuring, e aplicações. Na parte de cristalização homogênea (ou de áreas relativamente grandes) foram considerados os seguintes sistemas: filmes de a-Si:H dopado com $\mathrm{Er}^{3+}$, e filmes de a-Ge depositados sobre substratos de GaAs cristalino. No primeiro caso, o objetivo era investigar 0 efeito de diferentes tipos de tratamento sobre a ativação óptica dos íons $\mathrm{Er}^{3+}$, de forma que os filmes foram submetidos a tratamentos térmicos convencionais até $500{ }^{\circ} \mathrm{C}$, com radiação laser pulsada ( $\mathrm{Nd}-\mathrm{YAG}$ em $532 \mathrm{~nm}$ ), e com radiação laser $\mathrm{cw}\left(\mathrm{Ar}^{+}\right.$, em $\left.515.5 \mathrm{~nm}\right)$. Ainda que os tratamentos com radiação laser, efetivamente, tenham 
induzido a cristalização dos filmes, a melhora das propriedades luminescentes dos filmes é bastante inferior àquela obtida com os tratamentos convencionais. No segundo caso (a-Ge/GaAs), o objetivo era avaliar a produção filmes de Ge cristalino. Para tanto, o sistema a-Ge/GaAs foi submetido a tratamentos com radiação laser (Nd-YAG em 532 nm, 7 ns) e a investigação deu-se mediante a utilização de espectroscopia Raman, análises composicionais, e técnicas de microscopia eletrônica (SEM e TEM). O procedimento de MIC mostrouse bastante eficaz na obtenção de filmes de Ge epitaxial - cujas características finais (orientação, textura, etc.) dependem da densidade de energia da radiação laser. Todo o trabalho envolvendo o sistema Ge/GaAs foi feito em colaboração com a UNICAMP e com o Paul-Drude Institute (Berlim).

A cristalização de áreas relativamente grandes $\left(\sim \mathrm{mm}^{2}\right)$ de filmes de a-Ge sobre GaAs foi seguida pela geração de padrões microscópicos regulares (ou laser structuring) destes. Para tanto, a superfície das amostras foi sujeita à incidência de dois feixes coerentes de radiação laser, de modo a gerar um padrão de interferência com máximos e mínimos de intensidade luminosa (ou temperatura). Da mesma forma que no caso anterior, foi possível induzir a cristalização de $\mathrm{Ge}$, com características que dependem das condições adotadas. Mais especificamente, foram produzidas linhas de Ge cristalino (período de $\sim 1 \mu \mathrm{m}$ ) sobre o GaAs, cujo formato final em relevo era altamente dependente: da densidade de energia utilizada, dos mecanismos de transferência de calor e de material, e do procecesso de re-cristalização do $\mathrm{Ge}$.

Como exemplos de aplicação foram apresentados dois processos baseados no laser structuring de filmes de a-GeN. Em uma das situações mostramos a viabilidade da técnica na geração de grades de relevo (ou difração óptica), a qual está associada à ação conjunta de cristalização do Ge e explusão de átomos de nitrogênio da matriz do a-GeN. O outro tipo de aplicação ilustrado leva em consideração uma metodologia desenvolvida no LFF onde padrões microscópicos luminescentes foram gerados a partir da cristalização seletiva de filmes de a-GeN dopados com diferentes íons terra-rara. A metodologia, além de extremamente simples (sem exigir condições especiais tais como atmosfera, processos litográficos, etc.), permite a produção de estruturas luminescentes com dimensões típicas da ordem de $1 \mu \mathrm{m}$, as quais podem ser de grande interesse na confecção de micro-dispositivos opto-eletrônicos.

Pelo (muito) pouco do trabalho realizado no LFF até então, fica claro que o estudo dos mecanismos de cristalização de filmes semicondutores amorfos é tão complexo quanto interessante. Todo e qualquer avanço significativo nesta área deve estar baseado em, ao menos, duas características fundamentais - nem sempre presentes nos trabalhos disponíveis na literatura: realização de investigações sistemáticas, e utilização de diferentes técnicas de caracterização experimental. Isto torna-se necessário (e óbvio) a partir do momento em que se pretende fundamentar o trabalho realizado em informações que sejam comparáveis e, principalmente, consistentes entre si. $O$ desenvolvimento e/ou utilização de modelos matemáticos fazem-se necessários e, com toda certeza, devem contribuir para o entendimento dos mecanismos de cristalização. Enquanto estes existem e parecem descrever apropriadamente os resultados em sistemas vítreos, o mesmo não ocorre para o caso dos filmes finos - onde as interações filme-substrato nem sempre são óbvias e/ou passíveis de uma descrição simples. Além dos processos de MIC e LIC (e, obviamente o de tratamento térmico convencional) devem ser considerados, ainda, os de CIC (current induced crystallization) e PIC (pressure induced crystallization). Os quais, tendo-se por base suas características e particularidades, certamente, contribuirão com informações relevantes acerca dos mecanismos microscópicos de cristalização. 


\section{Referências}

1 I. Gutzow and J. Schmelzer, in The Vitreous State (Springer, Berlin 1995).

2 Y.I. Frenkel, in The Kinetic Theory of Liquids (Oxford University Press, Oxford 1946).

${ }^{3}$ S.R. Elliott, in Physics of Amorphous Materials (Wiley, Essex 1990).

${ }^{4}$ R. Zallen, in The Physics of Amorphous Solids (John Willey \& Sons, New York 1983).

${ }^{5}$ R. A. Street, in Hydrogenated Amorphous Silicon (Cambridge University Press, Oxford 1991).

6 J.S. Blakemore, in Solid State Physics (Cambridge University Press, Cambridge 1988).

${ }^{7}$ M. Madelung, in Introduction to Solid State Physics (Springer, Berlin 1978).

8 Vários são os textos disponíveis a respeito do assunto, veja por exemplo, F. Yndurain, and P. Ordejón, Philos. Mag. B 70, 535 (1994) e referências internas.

${ }_{9}$ M.F. Thorpe and M.I. Mitkova (Eds), in Amorphous Insulators and Semiconductors, NATO Advanced Study Institute Vol. 23 (Kluwer Academic Publishers, Dordrecht 1997).

10 D. Weaire, Phys. Rev. Lett. 26, 1541 (1971).

11 M.F. Thorpe and D. Weaire, Phys. Rev. Lett. 26, 1581 (1971).

12 N.F. Mott and E.A. Davis, in Electronic Processes in Non-Crystalline Materials (Clarendon Press, Oxford 1979).

${ }^{13}$ M. Stutzmann, in Amorphous Semiconductors, não publicado.

${ }^{14}$ K. Tanaka, E. Maruyama, T. Shimada, and H. Okamoto, in Amorphous Silicon (John Wiley \& Sons, Chichester 1999).

${ }^{15}$ B. Chapman, in Glow Discharge Processes, Sputtering and Plasma Etching (John Wiley \& Sons, NY 1980).

${ }^{16}$ K.J. Klabunde (Ed.), in Thin Films from Free Atoms and Particles (Academic Press Inc., Orlando 1985).

${ }_{17}$ M.J. Thompson, in The Physics of Hydrogenated Amorphous Silicon I - Topics in Applied Physics, Vol. 55, Ed. J.D. Joannopoulos and G. Lucovsky, (Springer-Verlag, Berlin 1984) e, referências internas.

18 J.L. Vossen and W. Kern (Eds.), in Thin Film Processes (Academic Press, NY 1978).

19 Website: Hhttp://www.iuvsta.org/IUVSTA_Educational_Material.htmlH , acessado em Janeiro de 2011.

${ }^{20}$ F. Oki, Y. Ogawa, and Y. Fujiki, J. J. Appl. Phys. 8, 1056 (1969).

${ }^{21}$ S. R. Herd, P. Chaudhari and M. H. Brodsky, J. Non-Cryst. Solids 7, 309 (1972).

22 T. J. Konno and R. Sinclair, Philos. Mag. B 66, 749 (1992).

${ }^{23}$ V. Subramanian and K.C. Saraswat, IEEE Trans. Electron. Devices 45, 1934 (1998).

24 T. Ito, H. Fukushima, and M. Yamaguchi, J. J. Appl. Phys. 42, 1526 (2003).

25 W. H. Zachariasen, J. Am. Chem. Soc. 54, 3841 (1932).

26 Z. Jin, G.A. Bhat, M. Yeung, H.S. Kwong, and M. Wong, J. Appl. Phys. 84, 194 (1998).

${ }^{27}$ E. A. Guliants and W.A. Anderson, J. Appl. Phys. 89, 4648 (2001).

${ }^{28}$ S.D. Ferris, H.J. Leamy, and J.M. Poate (Eds.), in Laser-Solid Interactions and Laser Processing (American Institute of Physics, NY 1979).

29 J.M. Poate and J.W. Mayer (Eds.), in Laser Annealing of Semiconductors (Academic Press, NY 1982).

${ }^{30}$ P.L. Liu, R. Yen, N. Bloembergen, and R.T. Hogson, Appl. Phys. Lett. 34, 864 (1979).

31 J.S. Williams, W.L. Brown, H.J. Leamy, J.M. Poate, J.W. Rogers, D. Russeau, G.A. Rozgonyi, J.A. Shelmutt, and T.T. Sheng, Appl. Phys. Lett. 33, 542 (1978). 
32 H.S. Chen and D. Turnbull, J. Appl. Phys. 40, 4214 (1969).

${ }_{33}$ M. Heintze, P.V. Santos, C.E. Nebel, and M. Stutzmann, Appl. Phys. Lett. 64, 3148 (1992).

${ }^{34}$ I. Chambouleyron, F. Fajardo, and A.R. Zanatta, Appl. Phys. Lett. 79, 3233 (2001).

35 F.E.F. Tolosa, in "Dopagem tipo-p de filmes de germânio amorfo hidrogenado", Tese (Doutorado em Ciências Físicas) 123 pp., Instituto de Física Gleb Wataghin - Universidade Estadual de Campinas - 1994.

36 I. Chambouleyron, F. Fajardo, and A.R. Zanatta, J. Non-Cryst. Sol. 299-302, 143 (2002)

${ }^{37}$ A.R. Zanatta and I. Chambouleyron, J. Appl. Phys. 97, 094914 (2005).

38 G. Dalba, P. Fornasini. R. Grisenti, F. Rocca, D. Comedi, and I. Chambouleyron, Appl. Phys. Lett. 74, 281 (1999).

${ }^{39}$ F. Fajardo, A.R. Zanatta, and I. Chambouleyron, phys. stat. sol. (b) 242, 1906 (2005).

40 F. Fajardo, A.R. Zanatta, and I. Chambouleyron, phys. stat. sol. (c) 2, 3750 (2005).

${ }^{41}$ L.R. Muniz, C.T.M. Ribeiro, A.R. Zanatta, and I. Chambouleyron, J. Physics: Cond. Matter 19, 076206 (2007).

42 F.A. Ferri, in "Cristalização induzida por níquel em filmes de silício amorfo", Dissertação (Mestrado em Física Aplicada) 85 pp., Instituto de Física de São Carlos - Universidade de São Paulo - 2007.

${ }^{43}$ F.A. Ferri, A.R. Zanatta, and I. Chambouleyron, J. Appl. Phys. 100, 094311 (2006).

${ }^{44}$ A.R. Zanatta and F.A. Ferri, J. Appl. Phys. 102, 043509 (2007).

${ }^{45}$ I. de Wolf, Semicond. Sci. Technol. 11, 139 (1996).

${ }^{46}$ F.A. Ferri and A.R. Zanatta, J. Appl. Phys. 104, 013534 (2008).

47 I. Honma, H. Komiyama, and K. Tanaka, J. Appl. Phys. 66, 1170 (1989).

${ }^{48}$ N. Maley, D. Beeman, and J.S. Lannin, Phys. Rev. B 38, 10611 (1988).

49 F.A. Ferri and A.R. Zanatta, J. Phys. D: Appl. Phys. 42, 035005 (2009).

50 M.J.V. Bell, L.A.O. Nunes, and A.R. Zanatta, J. Appl. Phys. 86, 701 (1999).

${ }^{51}$ P.V. Santos, A. Trampert, F. Dondeo, D. Comedi, H.J. Zhu, K.H. Ploog, A.R. Zanatta, and I. Chambouleyron, J. Appl. Phys. 90, 2775 (2001).

52 P.V. Santos, A.R. Zanatta, U. Jahn, A. Trampert, F. Dondeo, and I. Chambouleyron, J. Appl. Phys. 91, 2916 (2002).

53 P.V. Santos, A.R. Zanatta, F. Dondeo, A. Trampert, U. Jahn, D. Comedi, M.A. Pudenzi, and I. Chambouleyron, J. Non-Cryst. Sol. 299-302, 137 (2002).

${ }^{54}$ M. Mulato, A.R. Zanatta, D. Toet, and I. Chambouleyron, Appl. Phys. Lett. 81, 2731 (2002).

${ }^{55}$ A.R. Zanatta and C.T.M. Ribeiro, J. Appl. Phys. 96, 5977 (2004). 


\section{Capítulo 3}

\section{Propriedades ópticas-eletrônicas de filmes finos dopados com ions terra-rara}

\section{Introdução}

\section{Motivação}

Os fótons, da maneira como os concebemos hoje (unidades fundamentais de radiação eletromagnética e que se deslocam a impressionantes $3 \times 10^{8} \mathrm{~m} / \mathrm{s}$ ), têm nos influenciado desde a origem do Universo, ou do Big Bang. Diga-se de passagem, não é exagero considerar que muitos marcos da civilização humana tiveram origem em eventos baseados e/ou empregando fótons (radiação eletromagnética): descoberta e controle do fogo; observações astronômicas aliadas às atividades de plantio e colheita de alimentos; desenho e construção de elementos ópticos tais como espelhos, lentes, e prismas; o desenvolvimento da fotografia; as equações de Maxwell e suas consequências; 0 advento das fontes de radiação laser; utilização de radiação eletromagnética em procedimentos médico-cirúrgicos; etc. Nosso atual sistema de telecomunicações, em especial, é um exemplo notável de aplicação e da importância sócio-econômica desta fantástica entidade física - os fótons! 0 desenvolvimento efetivo da internet, por exemplo, foi possível apenas graças à impressionante velocidadecapacidade de informações promovida pela utilização de fibras-ópticas em telecomunicações (Figura 1) [1,2]. 


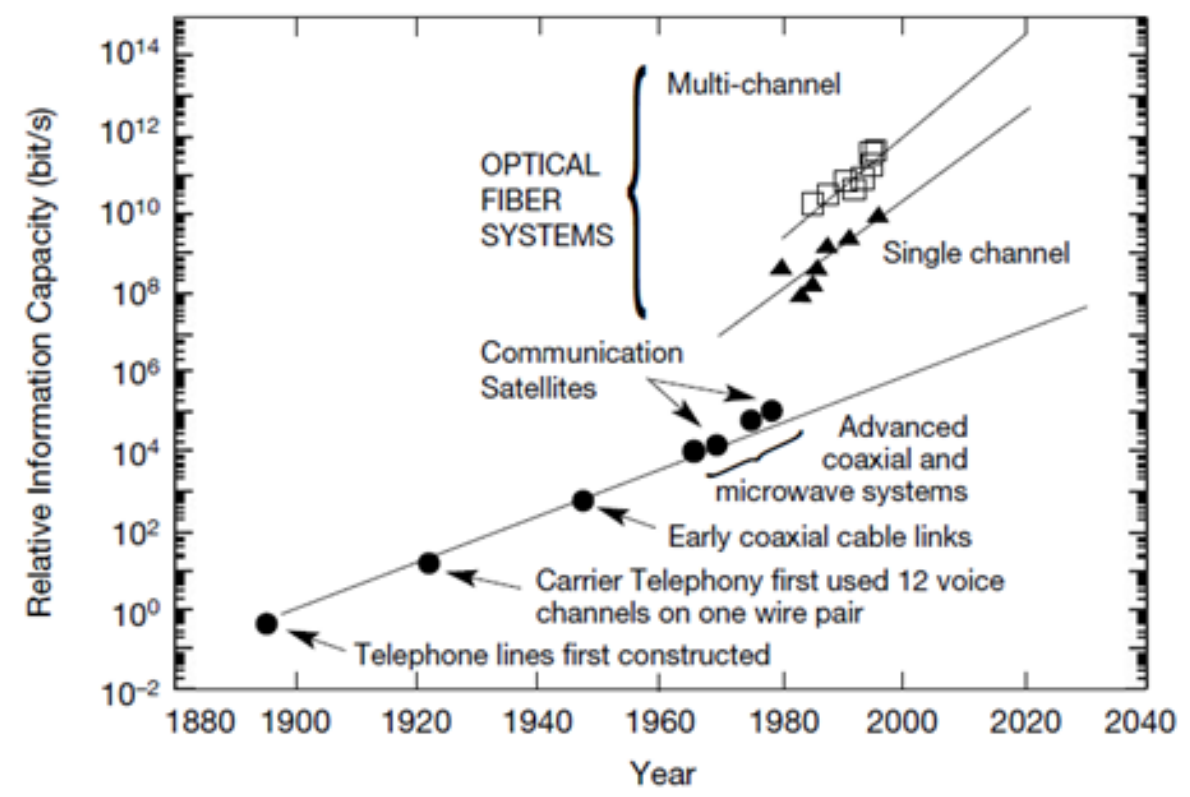

Figura 1 - Capacidade de transmissão de informação em função de diferentes tecnologias de (tele-)comunicações, entre $~ 1900$ e 2000 [1]. Os dados da figura indicam dois momentos marcantes: em 1980 com a implementação das fibras-ópticas e consequente desenvolvimento das redes de telecomunicação baseadas nestas, e em $\sim 1990$ com 0 acoplamento de amplificadores ópticos e multiplexadores às já existentes redes de telecomunicação.

Estritamente, remonta do início da década de 1960 o interesse pela transmissão e processamento de informações por meio de sinais ópticos ao invés de corrente elétrica. É desta época, também, o termo "óptica integrada", o qual se refere a uma geração de dispositivos ópticos-eletrônicos onde os condutores de elétrons e os dispositivos (puramente eletrônicos) são substituídos, respectivamente, por fibras ópticas e circuitos híbridos ópticos-eletrônicos [3,4]. O objetivo fundamental deste tipo de tecnologia (opto-eletrônica ou fotônica) baseiase na união das características singulares dos fótons com aquelas associadas aos elétrons e à tecnologia (micro-) eletrônica de forma a concentrar, em um único dispositivo, as operações de geração-transporteprocessamento-detecção de informação (Figura 2).

Além de se prestarem a propósitos diversos (telecomunicações, sensoriamento remoto, diagnóstico clínico, controle e segurança, etc.), os dispositivos fotônicos apresentam vantagens significativas tais como: maior velocidade de processamento; maior densidade de informação; possibilidade de miniaturização; ausência de interferência eletromagnética; baixo consumo energético; etc. Como resultado destas características, e das exigências impostas pela sociedade atual, o mercado de dispositivos fotônicos que se dedica à indústria de telecomunicações vem crescendo continuamente [1-4].

Tendo-se em conta que, praticamente toda nossa atual tecnologia (micro-)eletrônica está fundamentada no silício, o ideal seria o desenvolvimento de dispositivos fotônicos baseados (total ou parcialmente) neste material - elou associados a outros compostos com os quais este possua grande compatibilidade. Apesar da grande importância do silício na indústria micro-eletrônica, devido ao seu bandgap indireto, ele é um mau emissor de luz [5]. Como consequência, o silício cristalino tem se demonstrado inadequado em dispositivos ou aplicações que envolvam um eficiente processo de excitação-recombinação óptica. 


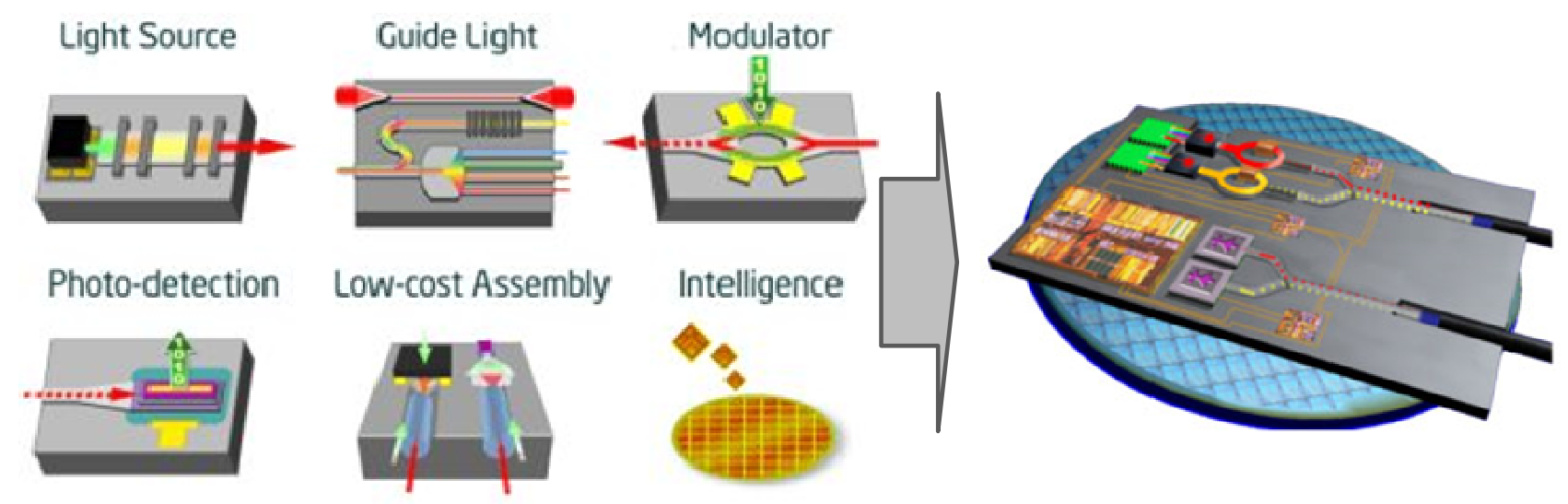

Figura 2 - llustração de algumas das principais características relativas ao princípio de funcionamento de um dispositivo fotônico (geração de informação sob a forma de radiação eletromagnética; transporte; modulação-processamento; detecção; possibilidade de integração em pequenas áreas e a custo reduzido; posterior utilização em sistemas mais complexos de processamento de dados). Fonte: http://techresearch.intel.com/articles/Tera-Scale/1419.htm.

No intuito de se superar esta "limitação", vários têm sido os esforços realizados. Dentre os mais promissores estão aqueles que se valem da relaxação das regras de seleção envolvendo o vetor de onda $\mathbf{k}$ (facilmente conseguido em sistemas desordenados e/ou com confinamento espacial) [6]. Para tanto, semicondutores amorfos [7], micro- ou nano-cristalinos [8], ou de baixa dimensionalidade [9] têm sido sistematicamente investigados. Outra possibilidade reside na utilização de compostos de Si sob a forma de ligas (como SiN ou SiC, por exemplo) com novas propriedades ópticas-eletrônicas. Uma terceira e última alternativa, igualmente conveniente, baseia-se na combinação de compostos à base de Si e de elementos opticamente ativos tais como íons terra-rara (RE- rare-earth) ou metais de transição (TM- transition metal) [10].

A combinação Si-RE, em particular, é considerada muito promissora para aplicações fotônicas e diversos trabalhos vêm sendo realizados na preparação de materiais à base de Si e dopados com diferentes íons terrarara $[10,11]$. Isto deve-se, em parte, ao fato de os íons $\mathrm{RE}$ apresentarem características tais como: amplo espectro de absorção e emissão (estendendo-se do ultravioleta ao infra-vermelho); blindagem de sua camada opticamente ativa $\left(4 f^{n}\right)$ pelos elétrons dos orbitais $5 s 5 p$, fazendo com que os comprimentos de onda de emissão e de absorção sejam praticamente insensíveis à matriz hospedeira; etc. Dentre os íons RE mais comumente estudados, o $\mathrm{Er}^{3+}$ destaca-se devido à sua emissão em $1540 \mathrm{~nm}$, que coincide com uma das janelas de transmissão das atuais fibras ópticas à base de sílica [11,12]. Além do $\mathrm{Er}^{3+}$ outros íons RE (isolados, ou sob a forma de combinações apropriadas) também apresentam grande interesse tecnológico para aplicação em fontes de radiação LED (light emitting diode) com emissão no UV-VIS-IV, sensores de temperatura, etc.

Uma visão geral do potencial fotônico que os materiais à base de silício apresenta pode ser apreciada na Figura 3. Na figura, temos um comparativo entre as diferentes regiões espectrais tipicamente apresentadas: pelo silício cristalino convencional (3D bulk Si); por sistemas de baixa dimensionalidade (1D polymeric Si e low dimensional $\mathrm{Si} \mathrm{SiO}_{2}$ system); por sistemas desordenados (device quality a-Si:H e porous Si); e por compostos dopados com íons terra-rara. Além da variedade de comprimentos de onda que podem ser extraídos do silício (Figura 3), é importante ressaltar sua alta eficiência (em sistemas de baixa dimensionalidade ou desordenados) bem como definição espectral (quando dopados com íons terra-rara, por exemplo). 


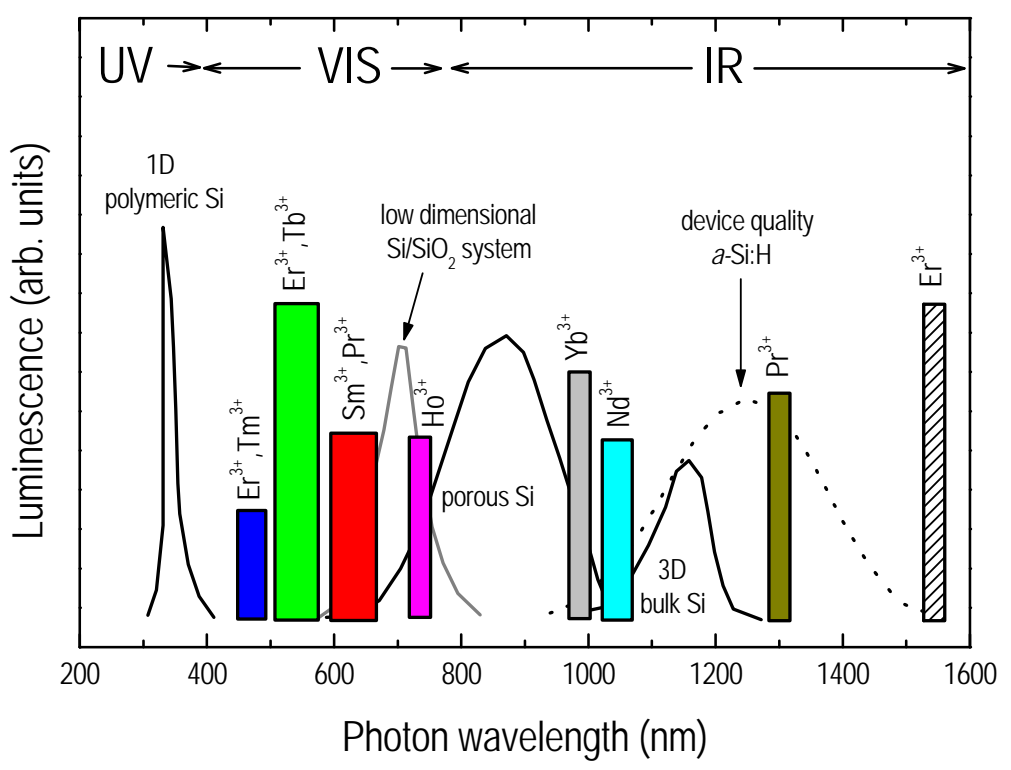

Figura 3 - llustração das regiões espectrais tipicamente verificadas pela emissão devida a sistemas baseados em silício [L. Canham, MRS Bull. (July 1993), D.J. Lockwood et al., Phys. Rev. Lett. 76, 539 (1996); S. Hayashi et al., J. Lumin. 70, 352 (1996)]. As emissões observadas em compostos dopados com diferentes íons terra-rara também estão representadas. Muito embora as intensidades de emissão sejam meramente ilustrativas podemos verificar que, quando devidamente combinados, compostos à base de Si podem dar origem a materiais emissores de luz em diferentes regiões do espectro de radiação eletromagnética.

Enquanto o emprego do silício e seus compostos em aplicações eletrônicas é uma realidade, a sua utilização em dispositivos híbridos fotônicos está sujeita ao desenvolvimento de novas combinações e/ou metodologias e ao estudo sistemático destas. Este é, justamente, o propósito deste trabalho.

\section{Conceitos Fundamentais}

\section{Os íons terra-rara}

Na Tabela Periódica, a série dos Lantanídeos é composta pelos 14 elementos a partir do Lantânio ( ${ }^{57}$ La) e é caracterizada pelo preenchimento sucessivo dos orbitais $4 f^{n}(n=1-14)$ com elétrons [13]. Em conjunto com 0 Escândio $\left({ }^{21} \mathrm{Sc}\right)$, Ítrio $\left({ }^{39} \mathrm{Y}\right)$, e 0 Lantânio $\left({ }^{57} \mathrm{La}\right)$, os Lantanídeos são frequentemente chamados de terra-rara (RE- rare-earth) e destacam-se por algumas propriedades singulares: (1) os elementos terra-rara caracterizamse por serem altamente eletropositivos e por existirem, predominantemente, sob a forma trivalente $\left(\mathrm{RE}^{3+}\right)$ [14]; (2) nesta forma, os elétrons pertencentes aos orbitais $4 f$ encontram-se blindados pelas camadas mais externas $5 s$ e $5 p$ e, consequentemente, as transições intra-4f são muito bem definidas e praticamente insensíveis ao ambiente em que se encontram; (3) estritamente, as transições intra-4f são proibidas por regras de seleção, mas tornam-se parcialmente permitidas pelas interações locais (chamadas de campo cristalino) mediante a mistura de funções de onda de paridade oposta [15]; (4) as emissões radiativas devidas a íons RE ${ }^{3+}$ geralmente são estreitas e costumam apresentar tempos de decaimento da ordem de ms; e (5) ainda que alguns íons RE bivalentes (como $0 \mathrm{Sm}^{2+}$ e $0 \mathrm{Eu}^{2+}$, por exemplo) também apresentem emissão radiativa, os íns $\mathrm{RE}^{3+}$ são os mais explorados. Em função destas características, a investigação das propriedades luminescentes de sistemas contendo íons $\mathrm{RE}^{3+}$ não é recente, sendo possível encontrar relatos científicos do 
início do século XX. A propósito, a primeira compilação de informações envolvendo os íons terra-rara em alguns sólidos cristalinos foi feita por Dieke em 1968 [16] (Figura 4), e os íons RE ${ }^{3+}$ vêm sendo regularmente empregados como materiais luminescentes (sob a forma de fósforos) já há várias décadas.

Ainda que sujeita às características da matriz hospedeira (dentre outros fatores), a Figura 4 dá uma idéia dos possíveis comprimentos de onda que podem ser conseguidos com íons terra-rara. Na figura temos representados os níveis, e correspondente energia, presentes nos íons $\mathrm{RE}^{3+}$. Por convenção, os níveis de energia nos íons $\mathrm{RE}^{3+}$ estão identificados de acordo com seus números quânticos de momento angular e de spin [17]. Segundo esta notação (espectroscópica): a letra refere-se ao momento angular orbital total do ín (série de Clebsh-Gordan); o índice superscrito indica o número de possíveis orientações do spin total do íon (na forma $2 \mathrm{~S}+1$, sendo $\mathrm{S}$ o spin total); e 0 índice subscrito denota o momento angular total conforme determinado por Russell-Saunders.

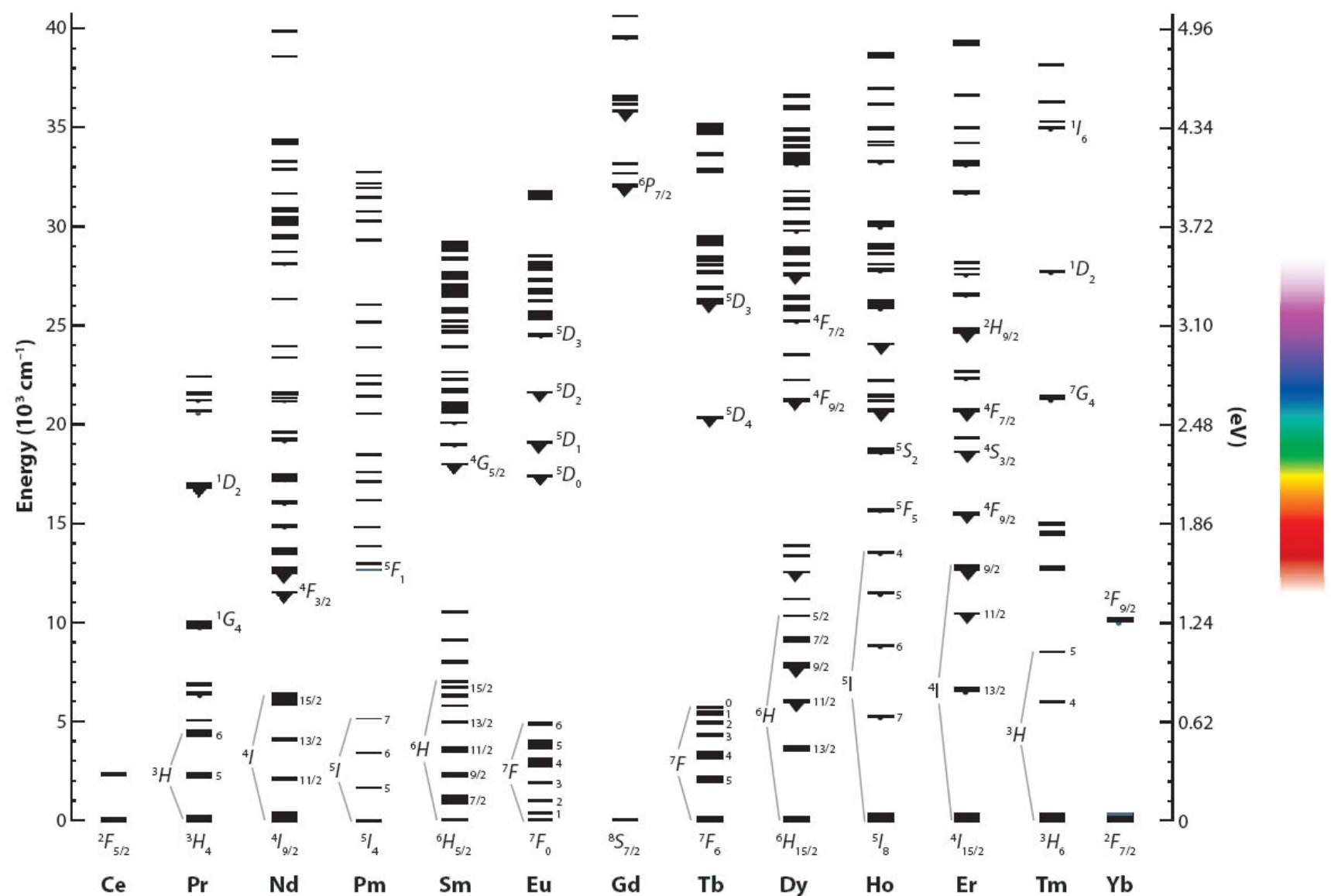

Figura 4 - Representação dos níveis de energia (também chamado de diagrama de Dieke [16]) para diversos íons terra-rara: $\mathrm{Ce}^{3+}$ $(n=1), \mathrm{Pr}^{3+}(n=2), \mathrm{Nd}^{3+}(\mathrm{n}=3), \mathrm{Pm}^{3+}(\mathrm{n}=4), \mathrm{Sm}^{3+}(\mathrm{n}=5), \mathrm{Eu}^{3+}(\mathrm{n}=6), \mathrm{Gd}^{3+}(\mathrm{n}=7), \mathrm{Tb}^{3+}(\mathrm{n}=8), \mathrm{Dy}^{3+}(\mathrm{n}=9), \mathrm{Ho}^{3+}(\mathrm{n}=10), \mathrm{Er}^{3+}(\mathrm{n}=11), \mathrm{Tm}^{3+}$ $(n=12)$, e $\mathrm{Yb}^{3+}(n=13)$. A figura apresenta a identificação (notação espectroscópica [17]) e as energias associadas a vários níveis eletrônicos.

Quando inseridos em um material semicondutor ou dielétrico, a excitação dos íons RE pode ocorrer de forma direta ou indireta. Dentre os mecanismos associados à excitação direta podemos mencionar: (d1) processo de excitação ressonante através da interação entre fótons com comprimento de onda próximo ou 
igual à energia de algum nível 4f; e (d2) envolvendo a colisão entre elétrons energéticos (mediante processos de catodo- ou de eletroluminescência) e os íons RE. Já no caso de excitação indireta destacam-se: (i1) transferência de energia por intermédio de portadores livres (em semicondutores); e (i2) acoplamento dipolodipolo ou Foerster-Dexter (em dielétricos) [18]. Qualquer que seja o mecanismo de excitação dos íons RE3+, este é altamente dependente das características do material (se cristalino ou amorfo, concentração de RE's e/ou de outras impurezas, etc.), e do método de excitação (fótons, elétrons, etc.). Outro aspecto importante refere-se à forma pela qual o íon $\mathrm{RE}^{3+}$ encontra-se inserido na matriz e, principalmente, como encontram-se distribuídos os seus níveis energéticos frente àqueles da matriz considerada. Um dos poucos materiais cristalinos dopados com $\mathrm{Er}^{3+}$ e que dispõe de informações completas a respeito da estrutura e dos mecanismos de excitação é o nitreto de gálio (GaN). Neste caso, os íons $\mathrm{Er}^{3+}$ entram em substituição de alguns átomos de $\mathrm{Ga}$ e assumem a simetria $\mathrm{C}_{3 v}$. Além disto, a luminescência dos íons $\mathrm{Er}^{3+}$ se dá a partir da transferência de energia de éxcitons aos elétrons do orbital $4 f, 0$ que pode ocorrer mediante 0 espalhamento inelástico ou pela recombinação destes [19]. É oportuno dizer, contudo, que o sistema GaN:Er ${ }^{3+}$ pode ser considerado um exceção já que, nem sempre, é possível obter informações tão detalhadas (ou conclusivas) a respeito de qualquer material dopado com íons terra-rara. Via de regra, isto só é possível em sistemas cristalinos e, principalmente, quando várias técnicas experimentais são combinadas. 0 principal tratamento teórico dado aos íns $\mathrm{RE}^{3+}$ é baseado no formalismo de Judd-Ofelt [20,21], através do qual é possível estimar as probabilidades de transição (ou oscillator strengths) associadas a cada nível eletrônico. Apesar de estar limitado à existência de alguns parâmetros tabelados, este tipo de formalismo é amplamente adotado no estudo de sistemas cristalinos e vidros dopados com íons terra-rara.

Muito embora o termo "blindagem" possa sugerir que os íons $\mathrm{RE}^{3+}$ sejam completamente indiferentes à vizinhança química local, é necessário certa cautela, uma vez que o campo cristalino pode exercer alguma influência sobre os elétrons $4 f$. Prova disto é o alargamento de níveis eletrônicos tipicamente verificado em íons $\mathrm{RE}^{3+}$ quando inseridos em matrizes amorfas, por exemplo. Além do mais, tanto a matriz quanto a temperatura são fatores determinantes nos processos de excitação e de recombinação dos íons $\mathrm{RE}^{3+}$. Mais apropriado, talvez, fosse postular que "devido aos orbitais $5 s$ e $5 p$, mais externos e totalmente preenchidos, o centro de gravidade das energias envolvidas nas transições intra- $4 f$ permanece praticamente inalterado - qualquer que seja a matriz e/ou a temperatura sob a qual o íon RE ${ }^{3+}$ esteja submetido".

Assim como em qualquer sistema envolvendo a combinação de dois ou mais elementos, a presença de íons $\mathrm{RE}^{3+}$ está sujeita ao limite de solubilidade da matriz hospedeira. A altas concentrações, os íons podem ocorrer sob a forma de agregados e/ou formar uma liga com algum dos elementos da matriz, reduzindo drasticamente a sua atividade óptica. Nestes casos, os agregados de íons $\mathrm{RE}^{3+}$ restringem ou extinguem a luminescência em um processo denominado de luminescence quenching - cuja origem pode ser devida ao aumento das interações íon-íon, ou à formação de alguma fase opticamente não-ativa. Desta forma, para muitos materiais, a concentração ideal de íons costuma ocorrer na faixa de $10^{20}-10^{21} \mathrm{~cm}^{-3}$ [10]. Outro fator que limita a luminescência devida aos íons $\mathrm{RE}^{3+}$ está relacionado à frequência de fônons da matriz hospedeira. Da mesma maneira que as interações íon-íon, 0 processo de relaxação envolvendo vários fônons pode rapidamente drenar a energia de elétrons excitados e levar àquilo que chamamos de extinção da luminescência pela temperatura (ou temperature induced luminescence quenching) $[22,23]$. Este efeito é particularmente grave em sistemas vítreos e motivo de atenção quando da concepção de novas matrizes luminescentes baseadas na emissão de íons $\mathrm{RE}^{3+}$. Outra questão a ser considerada, é quanto ao tipo de interação entre íons 
terra-rara: se entre íons iguais, ou entre diferentes íons $\mathrm{RE}^{3+}$ - quando passa a ser chamada de sensitização. No primeiro caso temos o processo de self-quenching, que nada mais é que um mecanismo de perda de energia via recombinação não-radiativa, e que deve ser evitado. Já o processo de sensitização pode ser ajustado de modo a promover a transferência de energia de um íon para outro permitindo outras possibilidades de excitação. Um exemplo clássico do processo de sensitização refere-se ao sistema Er+Yb onde a eficiência de emissão do $\mathrm{Er}^{3+}$ é consideravelmente aumentada a partir da coincidência das suas bandas de absorção com as do $\mathrm{Yb}^{3+}[24,25]$. A inserção de um novo íon $\mathrm{RE}^{3+}$ pode, ainda, reduzir as chances de formação de agregados e, consequentemente, de centros de recombinação não-radiativos. As interações entre íons $\mathrm{RE}^{3+}$ distintos foram consideradas em detalhe, pela primeira vez, por Foerster [26] e Dexter [27] em meados da década de 1950. Segundo este modelo, que se baseia no tempo de vida radiativo dos íons doadores e na densidade de íons aceitadores, pode-se inferir acerca do tipo de interação experimentado: dipolo-dipolo, dipoloquadrupolo, ou quadrupolo-quadrupolo. Um tratamento mais completo do processo leva em consideração a dinâmica da migração de energia entre os íons e foi proposta por Inokuti e Hirayama [28]. Uma descrição completa de todos os conceitos envolvidos nestes modelos está muito além dos propósitos deste trabalho e, portanto, serão apresentadas apenas referências onde o tema pode ser explorado com maior propriedade. Da mesma maneira, os processos relativos à interação entre íons $\mathrm{RE}^{3+}$ idênticos será aqui apenas mencionada, cabendo ao leitor interessado encontrar maiores detalhes na literatura [15,18,22,29]. Apenas a título de

ilustração vale citar os principais: (a) conversão ascendente cooperativa, (b) migração de energia, (c) relaxação cruzada, e (d) absorção de estado excitado.

\section{O sistema semicondutor $+R E^{3+}$}

"Optically active levels in the energy gap of semiconductors can also be observed in the infrared, although the lines are usually rather diffuse. Some recent results for $R E^{3+}$ in ZnSe have been given by Kingsley (1967) and for rare-earth sesquisulfides $\left(R E_{2} S_{3}\right)$ by Henderson, Muramoto, Loh, and Gruber (1967)".

O par de frases acima destacado foi extraído da página 26 do livro de Dieke [16] e retrata o estágio das pesquisas conduzidas no sistema semicondutor+RE ${ }^{3+}$ há cerca de 40 anos atrás. A considerar pelo escopo deste livro clássico que trata, essencialmente, da compilação-identificação de resultados espectroscópicos acerca de diversos materiais contendo íons terra-rara, não há como negar os avanços conquistados nas pesquisas envolvendo matrizes semicondutoras (ou dielétricas). Até o momento, e com a intenção de produzir novos materiais luminescentes e/ou dispositivos fotônicos, praticamente todos os compostos semicondutores conhecidos foram combinados com diferentes íons terra-rara [30,31]. Dentre os materiais considerados, e pelas razões expostas na Introdução, sobressaem-se aqueles envolvendo compostos à base de silício (cristalino, nano-cristalino, poroso, amorfo, sob a forma de ligas, etc.) em conjunto com o íon $\mathrm{Er}^{3+}$. Temos que destacar, contudo, o recente grande interesse pelo GaN dopado com diferentes íons $\mathrm{RE}^{3+}$ cujas potenciais aplicações vão desde a área de telecomunicações até a de displays [32]. O mesmo se aplica para o caso do nitreto de silício (SiN) que, além de exibir as mesmas potencialidades do GaN, é perfeitamente compatível com nossa atual indústria micro-eletrônica. Passemos, então, a uma breve descrição de algumas das principais características dos sistemas semicondutor+RE ${ }^{3+}$ mais estudados.

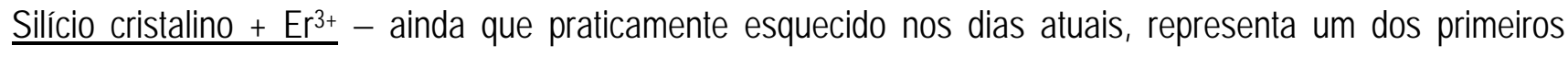
sistemas investigados [33]. Tradicionalmente produzido a partir da implantação de íons $\mathrm{Er}^{3+}$ em wafers de silício cristalino (tipo Czochralski ou float zone) e, em menor escala, pelas técnicas de deposição por MBE 
(molecular beam epitaxy) e MOCVD (metalorganic chemical vapor deposition) [34]. Aliado à sua tecnologia muito bem desenvolvida e grande seção de choque de absorção $\left(\sim 10^{-12} \mathrm{~cm}^{2}\right)$, o sistema Si+E $r^{3+}$ é limitado por: questões de solubilidade, pelo forte acoplamento entre os íons $\mathrm{Er}^{3+}$ e a matriz do c-Si, e pelo seu bandgap óptico ( $1.1 \mathrm{eV}$ ). Todos estes fatores fazem com que haja uma tendência à formação de agregados de $\mathrm{Er}$ (limitando a eficiência de emissão), e que o sistema esteja sujeito a uma forte extinção da luminescência com a temperatura. De qualquer forma, o sistema $\mathrm{Si}^{+} \mathrm{Er}^{3+}$ permitiu a verificação (e a investigação) de processos de foto- e eletro-luminescência de grande importância para os estudos que se seguiram envolvendo materiais diferentes [35]. Boa parte das pesquisas mais recentes envolvendo o sistema Si+Er ${ }^{3+}$ refe-se ao estudo dos mecanismos de interação entre os íons $\mathrm{Er}^{3+}$ e micro- ou nano-partículas de Si presentes em matrizes óxidas, por exemplo [36]. Dentro deste contexto, estes sistemas passam a ser melhor descritos pela terminologia $\mu \mathrm{c}-$ $\mathrm{Si}+\mathrm{Er}^{3+}$ ou nc-Si+Er${ }^{3+}$.

Silício amorfo hidrogenado $+\mathrm{Er}^{3+}$ - na tentativa de se minimizar (ou eliminar) os problemas de solubilidade $\mathrm{e}$ de bandgap do c-Si, os filmes de silício amorfo hidrogenado (a-Si:H) surgiram como candidatos naturais [37]. Neste caso, a inserção do $\mathrm{Er}^{3+}$ pode ser feita mediante a implantação de íons ou através de técnicas mais simples como a de cosputtering, por exemplo. Da mesma forma, tem-se controle sobre a introdução de hidrogênio e de outros tipos de impurezas nos filmes de a-Si. No primeiro caso, os átomos de hidrogênio são responsáveis pela abertura do bandgap óptico e passivação de dangling bonds [38], enquanto a presença de impurezas tais como oxigênio pode favorecer a atividade óptica dos íons $\mathrm{Er}^{\mathrm{r}^{3+}}[39,40]$. Além de reduzir consideravelmente os efeitos da temperatura sobre a luminescência do material, o sistema a-Si:H+E ${ }^{3+}$ permitiu uma investigação detalhada sobre a influência da natureza e da concentração de diferentes impurezas. Possibilitou, também, a construção de um dispositivo eletroluminescente extremamente simples que, operando à temperatura ambiente, emite radiação em $1540 \mathrm{~nm}$ [41]. Em praticamente todos os sistemas envolvendo íns terra-rara e uma matriz de Si, verifica-se um aumento significativo na intensidade de emissão de luz como resultado de tratamentos térmicos. Várias são as possíveis explicações para o fenômeno (as quais dependem dos detalhes de produção das amostras) e serão discutidas mais adiante.

Silício poroso $+\mathrm{Er}^{3+}$ - tendo-se em conta a blindagem dos íons $\mathrm{RE}^{3+}$ e do aumento de sua eficiência de emissão quando associados com nano-estruturas de Si e/ou com átomos de oxigênio, amostras de silício poroso ( $\pi$-Si) também foram consideradas na investigação do sistema semicondutores+RE ${ }^{3+}$. Assim como 0 a$\mathrm{Si}: \mathrm{H}, 0 \pi$-Si apresenta vantagens tais como: compatibilidade com a tecnologia do $\mathrm{Si}$, envolver uma metodologia de preparo relativamente simples, e modulação do bandgap óptico [42]. Em contrapartida, apresenta questões envolvendo sua estabilidade bem como da real origem dos mecanismos físicos envolvidos na geração de radiação devida à matriz - ainda hoje não está completamente estabelecido se estes se devem a confinamento quântico ou à presença de estruturas ricas em oxigênio (siloxeno). De qualquer forma, a grande influência de fatores ambientais (atmosfera e temperatura) sobre a condutividade do $\pi$-Si limitaram consideravelmente 0 interesse do sistema $\pi$-Si+E ${ }^{3+}$ para a confecção de dispositivos.

Estruturas ressonantes $+\mathrm{Er}^{3+}$ - os primeiros estudos relativos à inserção de íons $\mathrm{Er}^{3+}$ em estruturas ressonantes (ou micro-cavidades ópticas, ou refletores de Bragg, ou PBG photonic bandgap structure, ou estruturas de Fabry-Pérot) datam de meados de 1993 [43], ao que se seguiram vários outros estudos [44,45]. $\mathrm{Na}$ grande maioria dos casos, as estruturas são construídas a partir da intercalação de filmes de a-Si:H e a$\mathrm{SiO}_{2}$ com diferentes espessuras e índices de refração, sendo a camada ativa um filme de a-SiO ${ }_{2}$ dopado com 
íons $\mathrm{Er}^{3+}$. Micro-cavidades ópticas alternativas podem, ainda, ser confeccionadas a partir de filmes de a-SiN [46] ou de diferentes materiais e 0 íon $\mathrm{Tb}^{3+}$ [47] para atuar na região do espectro visível. Além de permitir a seleção de apenas um comprimento de onda, a união dos íons $\mathrm{RE}^{3+}$ com micro-cavidades aumenta a intensidade de emissão em, pelo menos, uma ordem de grandeza. Desta forma, a adequada combinação entre íons $\mathrm{RE}^{3+}$ e filmes semicondutores pode dar origem a dispositivos capazes de atuar na área de displays ópticos (região do visível) e/ou de telecomunicações (região do infra-vermelho).

Ligas à base de Silício + $\mathrm{Er}^{3+}$ - a inserção de íons $\mathrm{RE}^{3+}$ em ligas à base de SiC, SiN, ou SiO apresenta, ao menos, dois aspectos altamente interesssantes: permite a extração de radiação visível (devida aos íons $\mathrm{RE}^{3+}$ ) destes materiais, e reduz a extinção da luminescência pela temperatura (temperature induced photoluminescence quenching) - conforme discutiremos a seguir. Somem-se a estas características altamente desejáveis, a sua perfeita compatibilidade com a tecnologia do Si. Um dos primeiros estudos reportando a emissão de radiação visível (e infra-vermelha) devida a íons $\mathrm{Er}^{3+}$ no sistema semicondutor+E${ }^{3+}$ data de meados de 1998 [48] e tratou de filmes de a-SiN dopados com $\mathrm{Er}^{3+}$. Vários trabalhos semelhantes, versando sobre o GaN [49], sucederam o estudo de 1998 e, mais recentemente, o tema parece ter ganho atenção renovada [50].

Estes poucos parágrafos estão muito longe de expressar o real número e significado das pesquisas realizadas sobre o sistema semicondutor+RE ${ }^{3+}$. De qualquer forma, e independente da matriz e do íon escolhido, é importante que fique evidente que a investigação do sistema semicondutor+RE ${ }^{3+}$ sempre será de grande interesse acadêmico-tecnológico, uma vez que pressupõe o desenvolvimento de materiais aptos para a confecção de dispositivos ópticos-eletrônicos híbridos.

As pesquisas desenvolvidas no LFF, ao longo de mais de 10 anos, concentraram-se em compostos à base de silício amorfo preparado pela técnica de cosputtering. Tendo em consideração o caráter acadêmico destas pesquisas, foram realizados estudos sistemáticos envolvendo filmes com diferentes composições, estrutura, e íons terra-rara. Outros sistemas, que não apenas aqueles baseados em compostos de Si, também foram investigados em relativo detalhe. Passemos, então, a descrição sumária de alguns dos principais resultados obtidos no LFF na área de Propriedades Ópticas-Eletrônicas de Filmes Finos Dopados com Íons Terra-Rara. 
Resultados Experimentais na área de

Filmes finos dopados com íons terra-rara

Parte 1 - Filmes de silício amorfo hidrogenado (a-Si:H)

O primeiro trabalho realizado sobre o sistema a-Si:H+Er ${ }^{3+}$, no Brasil, data de 1997 [51] - ver quadro a seguir. $\mathrm{Na}$ época, este estudo foi feito a partir da cooperação entre o Lab. de Espectroscopia de Sólidos (IFSC) e 0 Lab. de Pesquisas Fotovoltáicas (UNICAMP). Os filmes de silício amorfo hidrogenado foram preparados, sob diferentes condições experimentais, pela técnica de cosputtering e investigados pelas técnicas de fotoluminescência ( $\mathrm{PL}$ ) e de espalhamento Raman. Como principais conclusões deste trabalho vale mencionar que (Figura 5): (1) a presença de átomos de hidrogênio, atuando como passivadores de defeitos, é essencial para a verificação da atividade óptica dos íons Er ${ }^{3+}$ com emissão em $1540 \mathrm{~nm}$; (2) da mesma forma, esta atividade é realçada nas amostras contendo nitrogênio e oxigênio; (3) como resultado da presença de centros de recombinação não-radiativos no a-Si:H, a emissão devida aos íons $\mathrm{Er}^{3+}$ é cerca de 5 vezes maior quando as medidas de PL são realizadas a baixas temperaturas (77 K); (4) as amostras submetidas a tratamentos térmicos até $\sim 500{ }^{\circ} \mathrm{C}$ apresentam um aumento substancial na intensidade de PL; e (5) até onde pudemos verificar, não há qualquer correlação entre a estrutura atômica do a-Si:H e a eficiência de emissão luminosa dos íons $\mathrm{Er}^{3+}$.

\section{Erbium luminescence from hydrogenated amorphous silicon-erbium prepared by cosputtering}

A.R. Zanatta, L.A.O. Nunes, and L.R. Tessler, Applied Physics Letters 70, 511 (1997)

Abstract - Hydrogenated amorphous silicon with small amounts of erbium (Er/Si concentration $\sim 5$ at.\%) was prepared by radio frequency sputtering from a Si target partially covered by tiny metallic Er chunks. Four sets of samples were studied: nonintentionally contaminated hydrogenated and nonhydrogenated amorphous silicon-erbium (a-SiEr:H and a-SiEr); nitrogen doped a-SiEr(N):H and oxygen contaminated a-SiEr(O):H. Samples from the first two sets present only faint $1.54 \mu \mathrm{m}$ photoluminescence characteristic from $\mathrm{Er}^{3+}$ ions even at $77 \mathrm{~K}$. Samples from the other sets show this luminescence at $77 \mathrm{~K}$ as deposited, without any further annealing step. Thermal annealing up to $500^{\circ} \mathrm{C}$ increases the photoluminescence intensity, and room temperature emissions become strong enough to be easily detected. These results indicate that in an amorphous silicon environment the chemical neighborhood of the $\mathrm{Er}^{3+}$ ions is crucial for efficient $1.54 \mu \mathrm{m}$ emission. Raman scattering from both as-deposited and annealed samples showed that network disorder relaxation by annealing is not determinant for efficient $\mathrm{Er}^{{ }^{3+}}$ luminescence.

Outra característica também abordada no trabalho diz respeito à influência de tratamentos térmicos simples ou do tipo cumulativo (com duração de $15 \mathrm{~min}$ cada, a temperaturas crescentes). Enquanto à temperatura ambiente parece não haver muitas diferenças entre os dois tipos de tratamento [Figura 5(a)], estas ficam bem evidentes quando as medidas de PL são realizadas a $77 \mathrm{~K}$ [Figura 5(b)]. Neste caso, os tratamentos térmicos cumulativos dão origem a uma intensidade de $\mathrm{PL}$ que chega a ser $~ 7$ vezes quando comparada às amostras que passam por apenas um único tratamento de 15 min - em uma clara alusão à eliminação de centros de recombinação não-radiativos.

Uma série de amostras análogas foi posteriormente submetida a medidas de absorção na região do infravermelho FTIR (Fourier transform infrared) de modo a poder avaliar o efeito da temperatura de tratamento térmico sobre a concentração de espécies leves como hidrogênio, nitrogênio e oxigênio sobre a intensidade de PL. Boa parte deste trabalho (também publicado em 1997 [52] - ver quadro a seguir) pretendia investigar a correlação existente entre o sinal de PL, a composição das amostras, e a temperatura de tratamento térmico. 


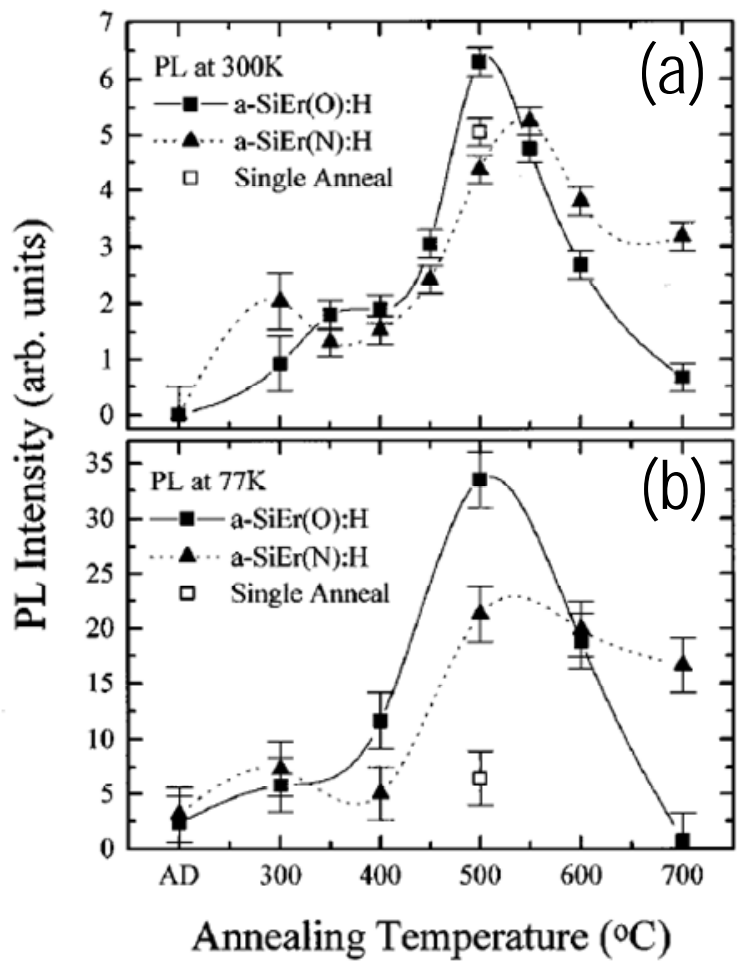

Figura 5 - Intensidade do sinal de foto-luminescência (PL), em função de diferentes condições de tratamento térmico, para filmes de a-Si:H dopados íons $\mathrm{Er}^{3+}$ contendo oxigênio (a-SiEr(O):H) ou nitrogênio (a-SiEr(N):H). Na figura temos as intensidades de PL obtidas a $300 \mathrm{~K}$ (a) e $77 \mathrm{~K}$ (b). AD diz respeito a amostras sem qualquer tipo de tratamento (as-deposited). Single anneal indica que a amostra foi tratada uma única vez a $500^{\circ} \mathrm{C}$ por $15 \mathrm{~min}$.

\section{Infrared spectroscopy of Er-containing amorphous silicon thin films}

A.R. Zanatta and L.A.O. Nunes, Applied Physics Letters 71, 3679 (1997)

Abstract - Hydrogenated amorphous SiEr (a-SiEr:H) thin films were deposited by cosputtering. Oxygen and nitrogen were employed as impurity enhancers of $\mathrm{Er}^{3+}$ emission of light at $1540 \mathrm{~nm}$, and photoluminescence, infrared absorption, and Raman spectroscopies were performed as a function of various annealing temperatures. As-deposited O-contaminated and N-doped a-SiEr:H samples exhibit $\mathrm{E}^{\mathrm{r}^{3+}}$ related photoluminescence, low intensity at room temperature, and maximum intensity after thermal annealing at $\sim 500^{\circ} \mathrm{C}$. In addition to the enhancement of the $\mathrm{Er}^{3+}$ emission of light, thermal annealing provokes the outdiffusion of hydrogen bonded to silicon atoms. The experimental data suggest that both hydrogen and thermal treatments improve the $\mathrm{Er}^{3+}$ related photoluminescence by decreasing the occurrence of nonradiative processes.

Para a série de amostras consideradas (filmes de a-SiEr(O):H e a-SiEr(N):H) foi possível estabelecer, de maneira contundente, a influência da concentração de hidrogênio, nitrogênio, e oxigênio sobre a eficiência de emissão devida aos íons $\mathrm{Er}^{3+} \mathrm{em} \sim 1540 \mathrm{~nm}$. Mais especificamente, os tratamentos térmicos realizados a temperaturas até $\sim 500-600^{\circ} \mathrm{C}$ têm como função re-ordenar a estrutura atômica dos filmes e induzir a difusão de espécies leves, de modo a promover a passivação das dangling bonds presentes no material. Tratamentos térmicos a temperaturas maiores, causam a exo-difusão de algumas destas espécies (hidrogênio e nitrogênio, principalmente) com o consequente fechamento do bandgap óptico do a-Si:H. Enquanto no primeiro caso (até $500-600{ }^{\circ} \mathrm{C}$ ) observa-se um aumento do sinal de $\mathrm{PL}$, os tratamentos a temperaturas maiores provocam justamente 0 contrário. 
Além de completamente originais, estes dois trabalhos foram o ponto de partida para a realização de outras investigações envolvendo o sistema a-Si:H+Er ${ }^{3+}$. Novas séries de amostras foram depositadas e novas hipóteses foram testadas - tendo sempre por objetivo principal, o entendimento dos mecanismos envolvidos na emissão de luz devida aos íons $\mathrm{Er}^{3+}$, sob o ponto de vista comparativo-quantitativo.

Em ordem cronológica, os trabalhos seguintes abordaram: a influência da concentração de Er sobre o sinal de PL [53] - ver quadro a seguir, e o efeito da atmosfera durante os tratamentos térmicos [54]. Em ambos os casos, os resultados foram apresentados no 17th International Conference on Amorphous and Microcrystalline Semiconductors (Budapeste- Hungria) e publicados em um volume especial do Journal of Non-Crystalline Solids. No primeiro caso (referência [53]) verificamos que para filmes de a-Si:H dopados com nitrogênio a concentração ideal de íons $\mathrm{Er}^{3+}$ encontra-se por volta de 0.5 at.\% (Figura 6), e no segundo caso (referência [54]) observamos uma melhora considerável no sinal de PL quando as amostras são tratadas termicamente em uma atmosfera de oxigênio.

\section{$1.54 \mu \mathrm{m}$ photoluminescence of Er-containing $\mathrm{N}-$ doped a-Si:H}

A.R. Zanatta and L.A.O. Nunes, Journal of Non-crystalline Solids 227-230, 389 (1998)

Abstract - Nitrogen-doped hydrogenated amorphous SiEr (a-SiEr:H) films were deposited by co-sputtering from an Er partially covered Si target. Photoluminescence, infrared absorption and Raman spectroscopies were performed as a function of thermal annealing treatments and Er concentrations. As-deposited N-doped a-SiEr:H samples exhibit $1.54 \mu \mathrm{m} \mathrm{Er^{3+ }}$ photoluminescence at room temperature and reaches its maximum after cumulative thermal annealing at $\sim 500{ }^{\circ} \mathrm{C}$. In addition to the $\mathrm{Er}^{3+}$ light emission increase, thermal annealing induces the effusion of hydrogen and nitrogen bonded to silicon atoms. The experimental data indicate that both the hydrogen and nitrogen concentration improve the $\mathrm{Er}^{3+}$ light emission at $1.54 \mu \mathrm{m}$ by decreasing the rate of non-radiative processes.

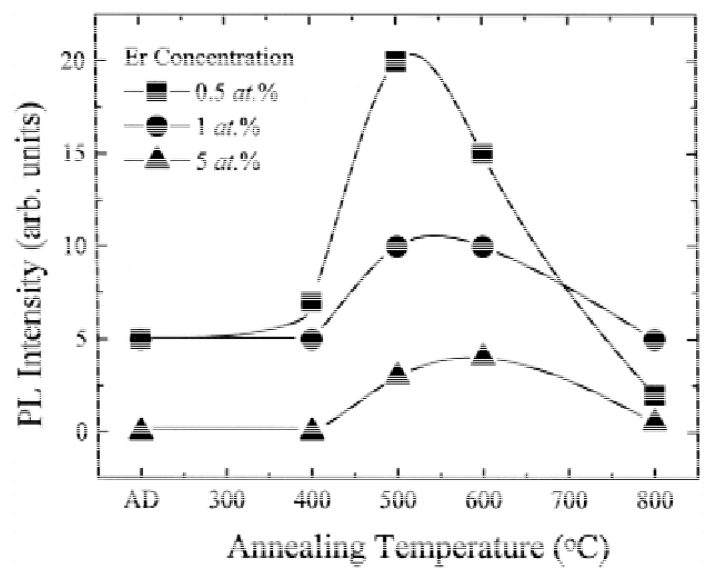

Figura 6 - Intensidade do sinal de foto-luminescência PL (à temperatura ambiente) para filmes de a-Si:H dopado com nitrogênio e com concentrações de Er iguais a 0.5, 1 e 5 at.\%. AD corresponde a amostras sem qualquer tratamento (as-deposited).

Sempre com o intuito de explorar a emissão radiativa dos íons $\mathrm{Er}^{3+}$, e os mecanismos que a determinam, os trabalhos que se seguiram foram realizados de forma ainda mais sistemática e envolveram a utilização de novas técnicas experimentais. Um trabalho publicado em 2000 [55] - ver quadro a seguir, em particular, além de tratar aspectos estruturais e composicionais de filmes de a-Si:H dopado com $\mathrm{Er}^{3+}$, apresentou uma explicação fenomenológica acerca das temperaturas ótimas de tratamento térmico em diferentes materiais à base de silício. Segundo este trabalho, ao menos três classes de materais podem ser identificadas cujas 
temperaturas ideais de tratamento térmico dependem de suas estruturas atômicas e de detalhes relativos à sua preparação. A Figura 7 apresenta os principais resultados obtidos, com as três classes de materiais identificadas por: (a) associada à presença de hidrogênio (hydrogen-related) cujo máximo de eficiência ocorre em $\sim 300^{\circ} \mathrm{C}$; (b) ricas em impurezas (impurity-rich) com máximo em $\sim 500-600{ }^{\circ} \mathrm{C}$; e (c) cristalinas (crystallike) com temperatura ótima $\geq 700^{\circ} \mathrm{C}$.

\section{Optical study of thermally annealed Er-doped hydrogenated a-Si films}

A.R. Zanatta and F.L. Freire Jr., Physical Review B 62, 2016 (2000)

Abstract - Erbium-doped hydrogenated amorphous silicon (a-SiEr:H) films were deposited by co-sputtering a Si target covered with small metallic Er pieces. After deposition the films were submitted to isochronal cumulative thermal anneals in an inert atmosphere of Ar. Rutherford backscattering, Raman spectroscopy, optical transmission, and photoluminescence measurements were employed for characterization purposes. Whereas thermal anneals at temperatures up to $\sim 300{ }^{\circ} \mathrm{C}$ do not cause significant changes in the composition, structure, and optical band gap of the present a-SiEr:H films, a considerable enhancement of the Er-related light emission at $1540 \mathrm{~nm}$ was verified. Thermal treatments at temperatures higher than $\sim 300{ }^{\circ} \mathrm{C}$ induce the outdiffusion of hydrogen atoms and consequent increase of structural disorder. Based on these experimental data, and on the available literature, some mechanisms related to the role played by thermal anneals on SiEr compounds are proposed and discussed.
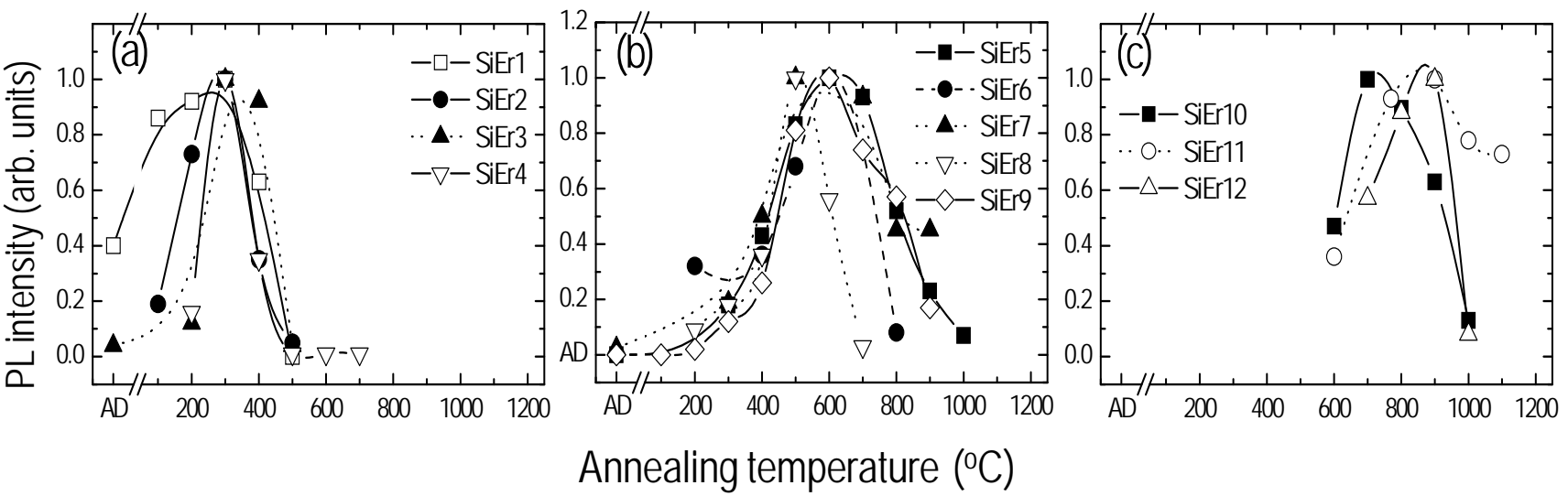

Figura 7 - Intensidade de foto-luminescência PL normalizada em função da temperatura de tratamento térmico, para diferentes materiais à base de silício dopados com íons $\mathrm{Er}^{3+}$. Em função dos resultados experimentais é possível identificar três classes de materiais: (a) hydrogen-related, (b) impurity-rich, e (c) crystal-like. Valem as seguintes referências: SiEr1 [PRB 62, 2016 (2000)], SiEr2 [Semicond. 33, 177 (1999)], SiEr3 [APL 68, 997 (1996)], SiEr4 [Semicond. 33, 93 (1999)], SiEr5 [JAP 78, 2642 (1995)], SiEr6 [JNCS 227-230, 389 (1998)], SiEr7 [APL 63, 1942 (1993), SiEr8 [APL 71, 3679 (1997)], SiEr9 [APL 72, 728 (1998)], SiEr10 [JAP 75, 2644 (1994)], SiEr11 [JAP 70, 2672 (1991)], e SiEr12 [PRB 54, 2532 (1996)].

Muito resumidamente, os resultados indicam que: (1) até que o máximo de emissão seja alcançado, os tratamentos a temperaturas crescentes induzem o re-arranjo da estrutura atômica das amostras e/ou a difusão de espécies (nas classes de materiais denominadas hydrogen-related e impurity-rich) bem como pode atuar na redução dos defeitos causados pelo processo de implantação (crystal-like); (2) uma vez atingido o máximo de eficiência de emissão, tratamentos a temperaturas ainda maiores levam à degradação do material através do desenvolvimento de centros de recombinação não-radiativos. Ainda que limitada, esta explicação é bastante ilustrativa na medida em que associa a energia (ou temperatura de tratamento) necessária para promover 
algum tipo de modificação em cada classe de material e, principalmente, está em perfeito acordo com os resultados experimentais obtidos em vários materiais diferentes, por diferentes grupos de pesquisa.

Este trabalho, assim como outros realizados no LFF, deixa evidente um aspecto - nem sempre presente nas publicações da área - que é o emprego de diferentes técnicas experimentais e a preocupação de estabelecer comparações entre diferentes sistemas.

$\mathrm{O}$ estudo de filmes de a-Si:H dopados com íons $\mathrm{Er}^{3+}$ foi retomado anos mais tarde, através do programa de Mestrado do Sr. Victor Oliveira [56]. Novas amostras foram preparadas por cosputtering e investigadas pelas técnicas de espectroscopia óptica, espalhamento Raman, foto-luminescência na região de 700-1700 nm, e análises composicionais por feixes de partículas (energy dispersive x-ray, Rutherford backscattering, e elastic recoil detection). Como diferencial deste trabalho, e a fim de verificar o fenômeno de sensitização, vale mencionar a investigação de filmes simultaneamente dopados com Er e Yb. Os principais resultados deste estudo foram objeto de uma publicação [57] - ver quadro a seguir, e estão resumidos nas Figuras 8 e 9.

\section{Optical properties of Er and Er+Yb doped hydrogenated amorphous silicon films}

V.I. de Oliveira, F.L. Freire Jr., and A.R. Zanatta, Journal of Physics: Condensed Matter 18, 7709 (2006)

Abstract - Hydrogenated amorphous silicon (a-Si:H) films were prepared by sputtering a Si target in an atmosphere of $\mathrm{Ar}+\mathrm{H}_{2}$. The $\mathrm{Er}$ (and $\mathrm{Er}+\mathrm{Yb}$ ) doping of the films was achieved by partially covering the Si target with small pieces of $\mathrm{Er}(\mathrm{Er}+\mathrm{Yb})$ metal. After deposition the films were annealed up to $700{ }^{\circ} \mathrm{C}$ in an inert atmosphere. Ion beam analyses, Raman spectroscopy, optical transmission and photoluminescence measurements were employed for characterization purposes. According to the experimental results, thermal treatments up to $\sim 300^{\circ} \mathrm{C}$ do not significantly alter the composition, atomic structure or optical bandgap of the present a-Si:H films. On the contrary, the Er-related photoluminescence intensity at $1540 \mathrm{~nm}$ increases and reaches its maximum at about 400

${ }^{\circ} \mathrm{C}$. Treatments at temperatures higher than $\sim 400{ }^{\circ} \mathrm{C}$ reduce both the Er-related light emission and the optical bandgap of the films due to the out-diffusion of hydrogen atoms. Furthermore, the relatively small optical bandgap and the presence of tail states prevent any optical activity of $\mathrm{Yb}^{3+}$ ions in the measured a-Si:H films. At the present doping levels and sample characteristics, ytterbium only increases the incidence of non-radiative processes.

O trabalho consistiu na investigação de uma série de amostras de a-Si:H (não-dopada, dopada apenas com Er, e dopada com Er+Yb com diferentes concentrações), as quais foram submetidas a tratamentos térmicos cumulativos até $700^{\circ} \mathrm{C}$. Além da composição das amostras, suas características ópticas-eletrônicas e estruturais foram estudadas após cada tratamento térmico. A Figura 8 apresenta os valores de bandgap óptico e da concentração de hidrogênio em função das diferentes temperaturas de tratamento térmico. Conforme pode ser verificado, tratamentos a temperaturas maiores que $\sim 400^{\circ} \mathrm{C}$ alteram drasticamente as propriedades dos filmes não-dopados e dopados apenas com $E r$, enquanto os amostras co-dopadas ( $\mathrm{Er}+\mathrm{Yb})$ apresentam modificações praticamente contínuas e suaves para todas as temperaturas testadas. Tal comportamento está diretamente associado à presença de centros de recombinação não-radiativos - essencialmente estados de cauda e dangling bonds - que, no caso dos filmes não-dopado e dopado com Er, são parcialmente suprimidos em tratamentos até $\sim 400 \mathrm{C}$, e intensificados para temperaturas maiores. Um raciocínio análogo pode ser aplicado ao caso do filme dopado com a menor concentração de $E r+Y b$, enquanto aquele com a maior concentração é praticamente insensível aos tratamentos térmicos. Estes aspectros ficam evidentes a partir da análise do sinal de foto-luminescência PL exibido pelas amostras, e estão representados na Figura 9. Enquanto para os filmes dopados o sinal de PL é aquele devido aos íons $\mathrm{Er}^{3+}(\mathrm{em} \sim 1540 \mathrm{~nm})$, para os filmes nãodopados o sinal refere-se a transições entre estados de cauda $(\mathrm{em} \sim 1100 \mathrm{~nm}$ ) e associados a defeitos (em 
$1300 \mathrm{~nm}$ ) [7]. A partir da realização deste estudo ficou estabelecido que, ainda que interessante, a matriz do aSi:H não é apropriada para a extração de radiação devida a íons $\mathrm{Yb}^{3+}$ e/ou para investigar o processo de sensitização envolvendo os íons $\mathrm{Er}^{3+} \mathrm{e} \mathrm{Yb}^{3+}$. Dentre vários fatores, isto deve-se ao caráter amorfo dos filmes e, principalmente, à coincidência entre os estados de cauda do a-Si:H e os níveis eletrônicos dos íons $\mathrm{Yb}^{3+}$ $[56,57]$.
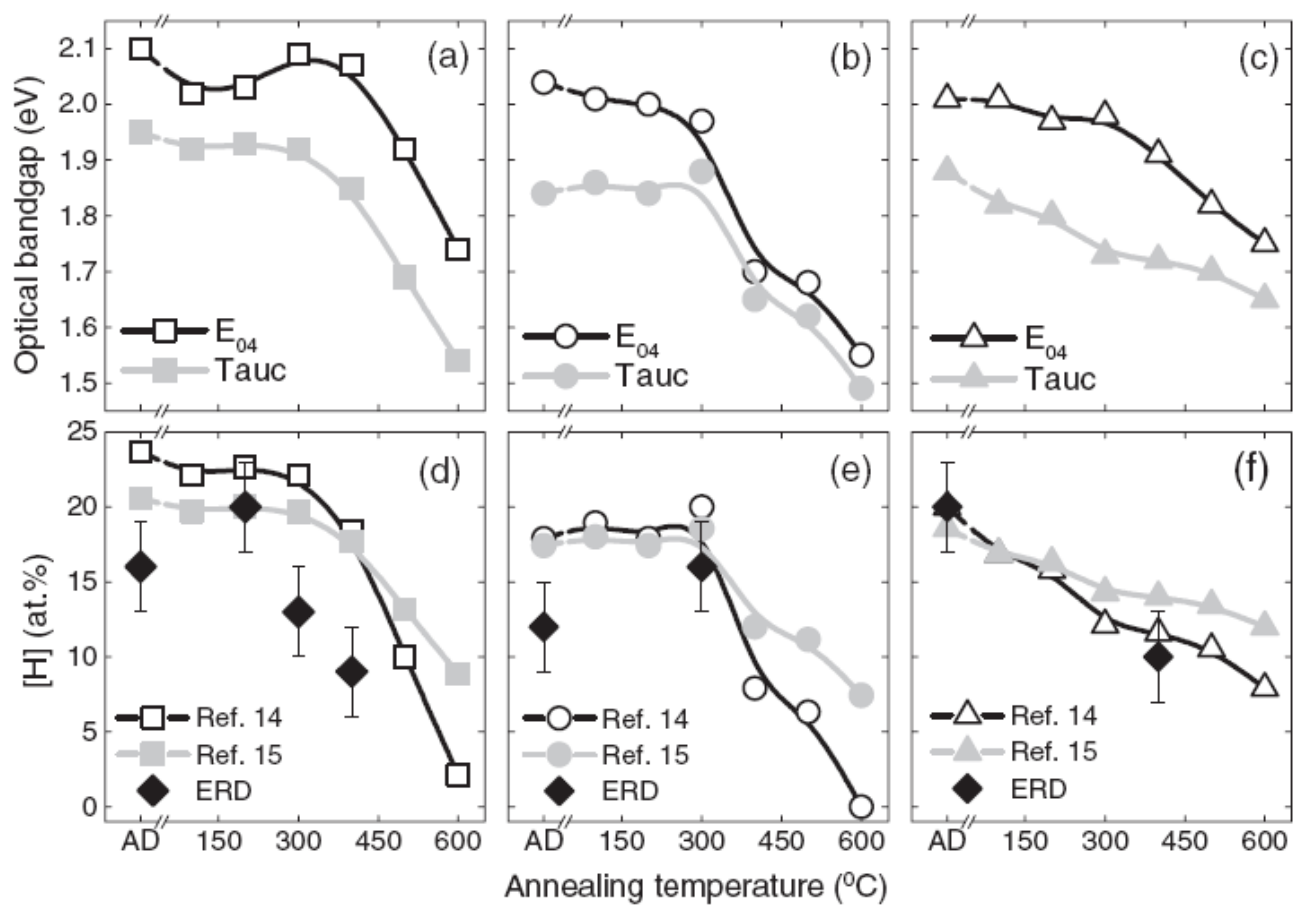

Figura 8 - Bandgap óptico e concentração de hidrogênio relativas a filmes de a-Si:H, tratados a diferentes temperaturas: nãodopados [(a)\&(d)], dopados com $\operatorname{Er}[(b) \&(e)]$, e dopados com $\operatorname{Er}+\mathrm{Yb}[(\mathrm{c}) \&(\mathrm{f})]$. Os valores de bandgap óptico [(a)-(c)] foram obtidos a partir das definições de $\mathrm{E}_{04} \mathrm{e}$ de Tauc [7], e as concentrações de hidrogênio [(d)-(f)] foram determinadas experimentalmente (ERD) e estimadas a partir de curvas de calibração [Ref. 14- JJAP 20, L183 (1981), e Ref. 15- AJP 9, 681 (2000)]. AD refere-se a amostras sem qualquer tipo de tratamento (as-deposited).
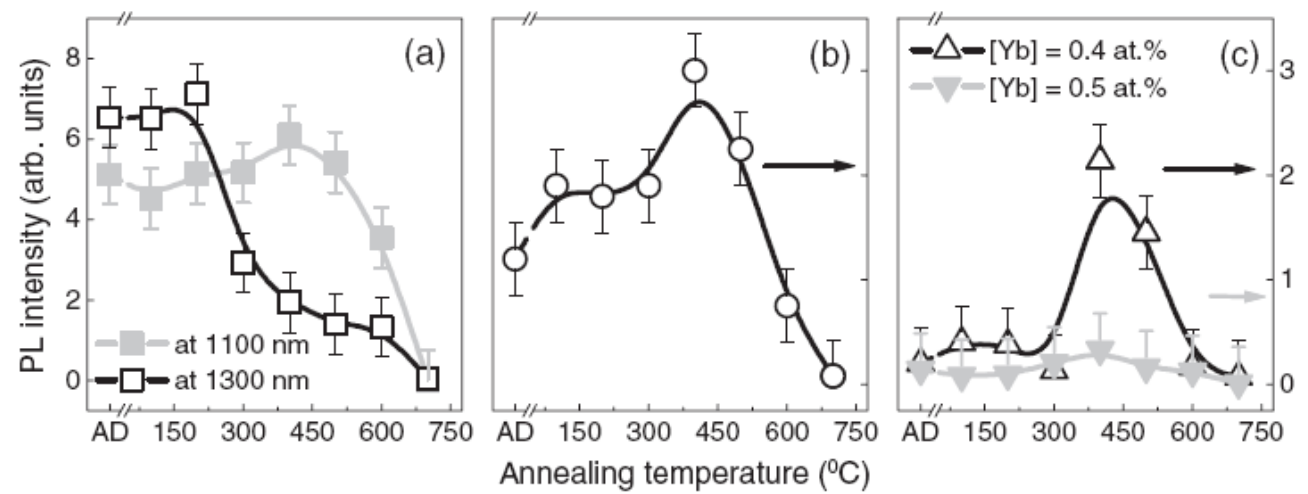

Figura 9 - Intensidade do sinal de foto-luminescência PL em função da temperatura de tratamento térmico para diferentes filmes de a-Si:H: (a) não-dopado, (b) dopado com Er, e (c) dopado com Er+Yb. Todas as medidas foram realizadas a $10 \mathrm{~K}$ mediante excitação com fótons de $488.0 \mathrm{~nm}$. As emissões verificadas nos filmes não dopados referem-se a transições entre estados de cauda (em $1100 \mathrm{~nm}$ ) e defeitos (em $1300 \mathrm{~nm}$ ). Em (b) e em (c) o sinal de PL está associado à transição $\left.4_{13 / 2} \rightarrow{ }^{4}\right|_{15 / 2}(\mathrm{em} \sim 1540 \mathrm{~nm})$ devida aos íons $\mathrm{Er}^{3+}$. Observe as diferentes escalas associadas à intensidade de PL nos filmes não-dopados e dopados. AD refere-se a amostras sem qualquer tipo de tratamento térmico. 
Parte 2 - Filmes de silício amorfo nitrogenado (a-SiN)

Sob os aspectos histórico, acadêmico, e até mesmo tecnológico, as pesquisas envolvendo a inserção do íon $\mathrm{Er}^{3+}$ no silício cristalino (c-Si) e no silício amorfo hidrogenado (a-Si:H) foram de fundamental importância. Tendo como principal atrativo a possibilidade de servirem de base para a confecção de dispositivos híbridos, as investigações envolvendo o $\mathrm{c}-\mathrm{Si}+\mathrm{Er}^{3+}$ e $0 \mathrm{a}-\mathrm{Si}: \mathrm{H}+\mathrm{Er}^{3+}$ foram responsáveis por um avanço sem precedentes na compreensão do sistema semicondutor $+\mathrm{Er}^{3+}$. Contudo, e independente de todo 0 interesse (econômico)tecnológico, a atividade óptica do $\mathrm{c}-\mathrm{Si}+\mathrm{Er}^{3+}$ e do a-Si:H+Er ${ }^{3+}$ é extremamente baixa, em especial, a temperaturas próximas à ambiente. Este problema foi observado em inúmeros trabalhos científicos e deve-se ao fenômeno de extinção da luminescência devida a processos térmicos (temperature-induced luminescence quenching). O fenômeno ocorre em praticamente todos materiais semicondutores, e tende a ser mais acentuado quanto menor o bandgap óptico - conforme observado, pela primeira vez em 1989, por Favennec e colaboradores [58]. A Figura 10 apresenta as curvas de intensidade do sinal de foto-luminescência, devida aos íons $\mathrm{Er}^{3+}(\mathrm{em} \sim 1540 \mathrm{~nm})$, em função do inverso da temperatura para diferentes materiais. Segundo a figura, todos os compostos apresentam uma diminuição da intensidade de PL (em maior ou menor escala, dependendo das características e dos detalhes associados ao preparo e tratamento das amostras) quanto maiores as temperaturas de medida.

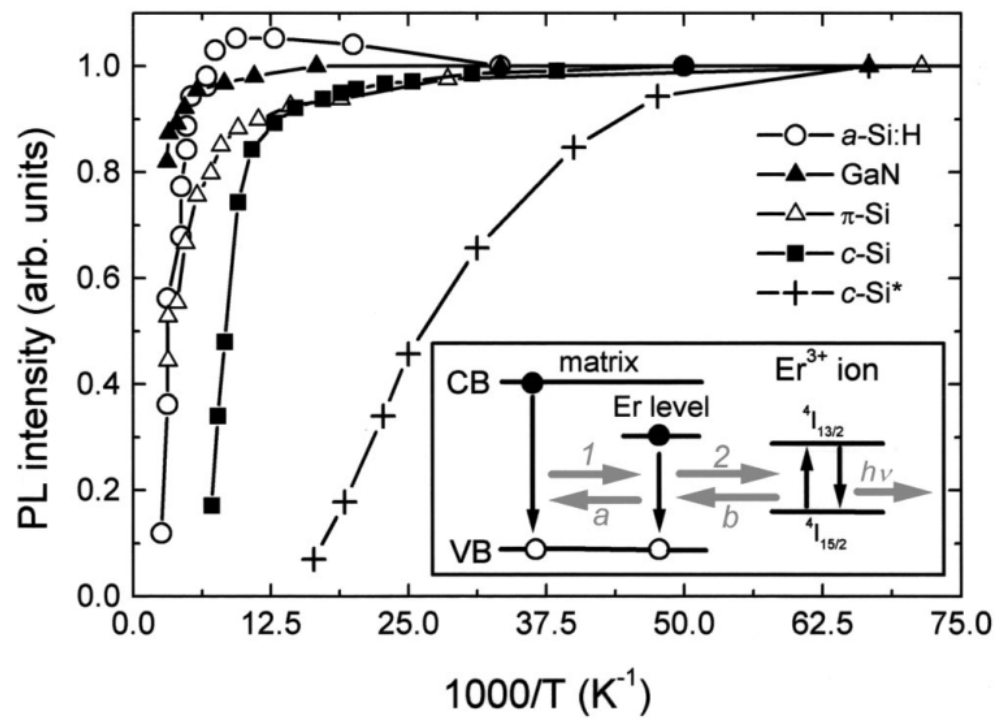

Figura 10 - Intensidade do sinal de foto-luminescência lpL devida a íons $\mathrm{Er}^{3+}$ (em $1540 \mathrm{~nm}$ ) em função do inverso da temperatura de medida, para: a-Si:H (Eg $1.5 \mathrm{eV}), \mathrm{GaN}(\mathrm{Eg} \sim 3.5 \mathrm{eV}), \pi-\mathrm{Si}(\mathrm{Eg} \sim 2 \mathrm{eV})$, e c-Si $(\mathrm{Eg} \sim 1 \mathrm{eV})$. Todas as curvas de IPL foram normalizadas (à mais baixa temperatura) para fins comparativos. $O$ insert da figura apresenta um diagrama com as bandas de valência (VB) e de condução (CB) do material semicondutor, e dos níveis $\left.{ }^{4}\right|_{13 / 2}$ e $\left.{ }^{4}\right|_{15 / 2}$ do íon $\mathrm{Er}^{3+}$. Os principais mecanismos de excitação (1 e 2) e recombinação (a e b, com $h v$ representando a emissão em $1540 \mathrm{~nm}$ ) do íon $\mathrm{Er}^{3+}$ estão indicados no insert. Os dados relativos ao $\mathrm{c}-\mathrm{Si}^{\star}$ referem-se a um dos primeiros resultados experimentais do sistema c-Si+E ${ }^{3+}$.

A figura sugere ainda: (i) a possibilidade de se determinar uma temperatura de extinção (Tq) do sinal de PL e (ii) que, por serem menos susceptíveis aos efeitos da temperatura, compostos de bandgap óptico grande (Eg $\geq 2 \mathrm{eV}$ ) sejam os mais apropriados para a confecção de dispositivos híbridos a partir do sistema semicondutor $+\mathrm{Er}^{3+}$. 
A questão da extinção do sinal de PL e, em especial, da determinação de $T q$ em vários materiais dopados com o íon $\mathrm{Er}^{3+}$ foi tratada em um trabalho de 2003 [59] - ver quadro a seguir, o qual passamos a discutir.

\section{Photoluminescence quenching in Er-doped compounds}

A.R. Zanatta, Applied Physics Letters 82, 1395 (2003)

Abstract - The temperature-induced quenching in the photoluminescence intensity (IPL) of $\mathrm{Er}^{3+}$ ions in different semiconductor hosts is discussed in this letter. Based on a compilation of several IPL $(T)$ experimental curves, corresponding to either crystalline or amorphous Er-doped samples, and after a critical data analysis, it was possible to determine a temperature of quenching $T q$ such that IPL $(T q)=$ 0.95 lpL (lowest T). These experimental Tq values have been analyzed in terms of certain host characteristics such as optical band gap and phonon frequency. As a result of this study it was possible to state that: (i) Tq strongly depends on the optical band gap and atomic structure of all studied semiconductor hosts; (ii) the host phonon frequency plays a minor role in the quenching of lPL ; and (iii) based on the partial ionic character of each semiconductor host, both the energy and the localization of the photon-generated electron-hole pairs determine the IPL quenching. Moreover, the present phenomenological model is consistent with the influence that codoping and thermal

anneals have on the IPL enhancement of Er-doped compounds.

O trabalho consistiu na análise crítica de resultados experimentais, obtidos por vários autores, na tentativa de se estabelecer a real influência do bandgap óptico sobre o fenômeno de extinção do sinal de fotoluminescência. Com este propósito, o manuscrito tem início com uma breve discussão acerca dos processos físicos envolvidos na excitação-recombinação dos íons Er ${ }^{3+}$. Conforme esquematizado no insert da Figura 10, a energia pode chegar aos íons $\mathrm{Er}^{3+}$ em duas etapas sucessivas: (1) captura de um par elétron-buraco $(e-h)$ por um nível associado ao Er presente no bandgap do material considerado (Er level), e (2) excitação dos elétrons $4 f$ através do processo Auger. Uma vez excitado, o íon $\mathrm{Er}^{3+}$ pode recombinar radiativamente, dando origem à emissão de um fóton $h v$ em $1540 \mathrm{~nm}$, por exemplo. Alternativamente, esta emissão de luz pode não ocorrer devido a processos não-radiativos: (a) o par $e-h$ pode recombinar antes que o processo Auger tenha vez (por ionização térmica), ou (b) após excitação dos elétrons 4f, o íon Er ${ }^{3+}$ perde energia para 0 nível associado ao Er (back transfer). O comportamento das curvas de $I_{P L}(T)$ também foi considerado e, a fim de permitir uma análise comparativa-qualitativa dos resultados, estabeleceu-se (arbitrariamente) que a temperatura de extinção $T q$ seria melhor descrita por $\mathrm{I}_{\mathrm{PL}}(T q)=0.95 \mathrm{I}_{\mathrm{PL}}{ }^{\max }$, ou seja: $T q$ corresponde à temperatura na qual a intensidade de PL diminui em $5 \%$ do seu máximo valor (geralmente obtido a temperaturas inferiores a $\sim 20 \mathrm{~K}$ ).

De posse dos valores da temperatura de extinção de PL ( $T q$ conforme definido acima) e dos valores de bandgap óptico $(\mathrm{Eg})$ de vários materiais dopados com $\mathrm{Er}^{3+}$, foi possível fazer uma representação de Tq versus Eg (Figura 11). A figura é bastante ilustrativa e demonstra que: (1) os valores de $T q$ possuem uma correspondência praticamente linear com o bandgap óptico de diferentes semicondutores dopados com $\mathrm{Er}^{3+}$; (2) devido à presença de defeitos (estruturais-eletrônicos), os valores de Tq são consideravelmente menores em materiais de estrutura amorfa. Tendo por base os resultados apresentados na Figura 11, o trabalho também permitiu concluir que: (3) ao contrário do verificado em alguns compostos dielétricos [22], não é a frequência de fônon da matriz hospedeira quem determina (exclusivamente) a temperatura de extinção do sinal de PL do sistema semicondutor+Er ${ }^{3+}$; e (4) 0 ambiente químico (ou caráter iônico) do sistema semicondutor+Er ${ }^{3+}$, 0 qual determina a energia e a localização do par e-h gerado, é decisivo na temperatura de extinção da PL - assim como no caso da correlação Tq versus Eg, quanto maior o caráter iônico do material, maior o valor de Tq. 


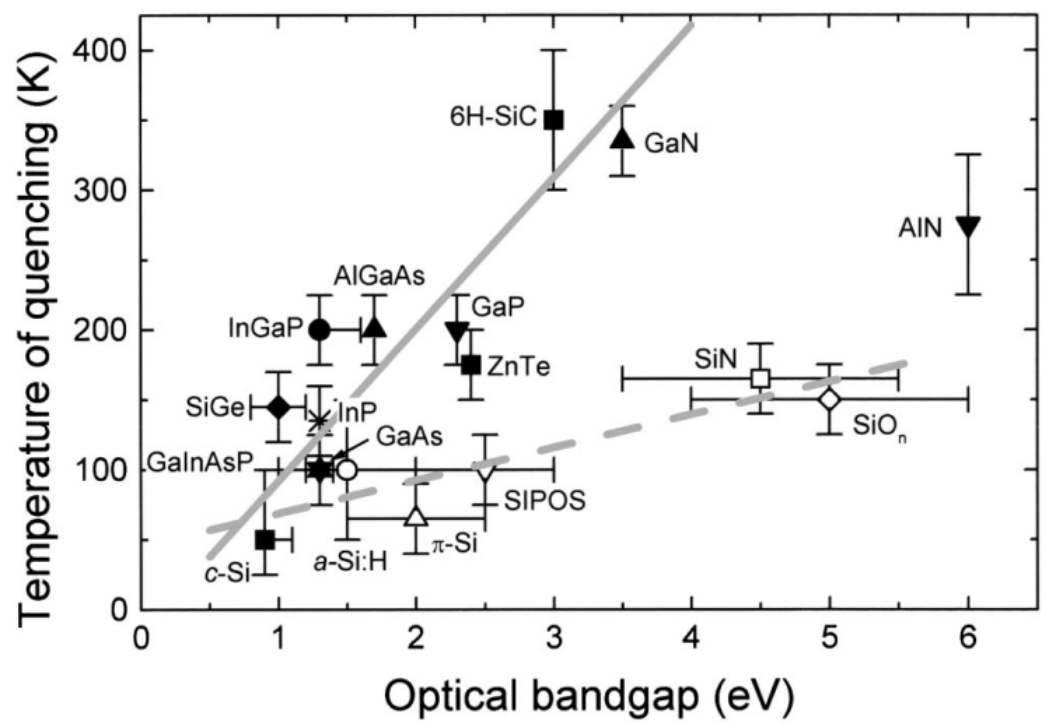

Figura 11 - Temperatura de extinção do sinal de foto-luminescência (em $1540 \mathrm{~nm}$ ) em função do bandgap óptico de diferentes materiais semicondutores dopados com Er. Os valores de $T q$ foram determinados a partir da definição $\operatorname{IPL}(T q)=0.95 \operatorname{lPL}^{\max }$. Os símbolos cheios (vazios) referem-se a compostos de estrutura cristalina (amorfa). As barras de erro levam em consideração diferenças entre diferentes autores, bem como imprecisões experimentais.

Muito tempo antes da realização deste trabalho acerca da extinção do sinal de PL, no entanto, muitos dos interesses do LFF já tinham se voltado para outras classes de materiais de bandgap óptico grande. Diga-se de passagem, além de investigar materiais com altos valores de $T q$, nossa intenção era também a de extrair radiação visível associada aos íons $\mathrm{RE}^{3+}$, bem como investigar os processos de excitação-recombinação associados. Dentro deste contexto, o primeiro estudo relativo à emissão de luz visível devida ao íon $\mathrm{Er}^{3+}$, em uma matriz à base de silício, foi publicado em 1998 [48] - ver quadro a seguir. O trabalho apresentou resultados de foto-luminescência na faixa de 500-1700 nm (Figura 12), obtidos a partir de filmes de silício amorfo nitrogenado (a-SiN), ou nitreto de silício amorfo, dopado com Er. Por apresentar um bandgap óptico de $3.5 \mathrm{eV}$, o sistema a-SiN+Er ${ }^{3+}$ permitia a emissão de radiação visível, bem como a verificação do sinal de PL à temperatura ambiente. $\mathrm{O}$ trabalho identificou todas as transições devidas ao íon $\mathrm{Er}^{3+}$, bem como discutiu em detalhe o mecanismo de excitação destes. Mais especificamente, tendo-se em conta a coincidência de energia entre fótons de $488.0 \mathrm{~nm}$ e 0 nível ${ }^{4} \mathrm{~F}_{7 / 2}$ do íon $\mathrm{Er}^{3+}$, o processo de excitação ocorre (predominantemente) de forma quase-ressonante.

\section{Green photoluminescence from Er-containing amorphous SiN thin films}

A.R. Zanatta and L.A.O. Nunes, Applied Physics Letters 72, 3127 (1998)

Abstract - Green light emission at room temperature was achieved from nonhydrogenated amorphous silicon-nitrogen (a-SiN) thin films. The films were deposited by cosputtering a silicon target covered with metallic erbium platelets in an $\mathrm{Ar}+\mathrm{N}_{2}$ atmosphere. According to the deposition conditions, the nitrogen concentration $[\mathrm{N}]$ reached $\sim 40$ at.\% rendering an optical gap of approximately 3.5 $\mathrm{eV}$ while the Er concentration [Er] was estimated to be $\sim 10$ at.\% in the present films. The high $[\mathrm{Er}]$ associated to the optical band gap allows the direct excitation of $\mathrm{Er}^{3+}$ ions. This optical excitation is more efficient at low temperatures as a consequence of the reduction in nonradiative processes, and when exciting the samples with the $488.0 \mathrm{~nm}$ line of an $\mathrm{Ar}^{+}$laser which is in resonance with the ${ }^{4} \mathrm{~F}_{7 / 2}$ $\mathrm{Er}^{3+}$ energy level. In addition to light emission at $\sim 520$ and $\sim 545 \mathrm{~nm}$, transitions in the infrared energy region could be easily verified in as-deposited samples. 

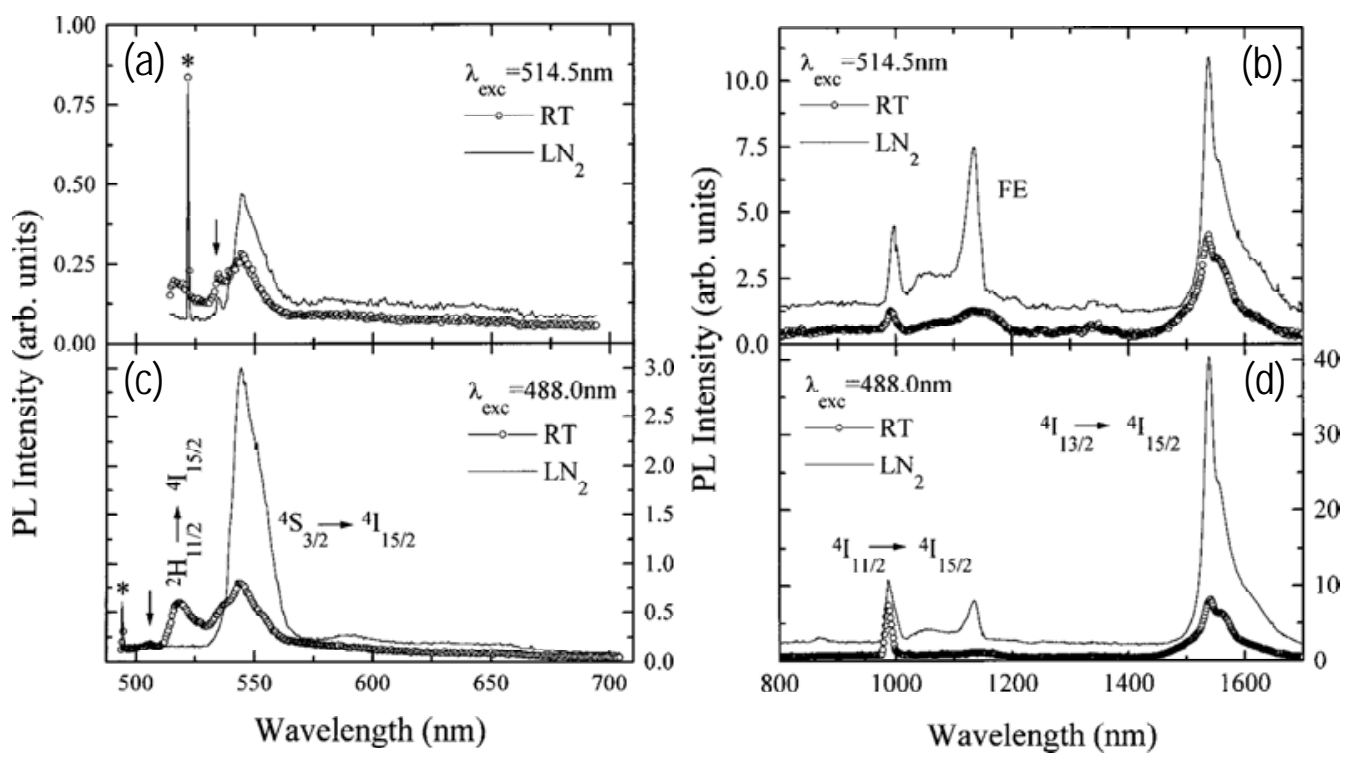

Figura 12 - Espectros de foto-luminescência (PL) nas regiões do visível ( 500-700 nm) e infra-vermelho próximo ( 800-1700 nm), devidos à emissão de íons $\mathrm{Er}^{3+}$ inseridos em uma matriz de a-SiN. Os espectros foram obtidos à temperatura ambiente (RT) e de nitrogênio líquido $\left(\mathrm{LN}_{2}\right)$ mediante excitação com um laser de $\mathrm{Ar}^{+}(514.5$ e $488.0 \mathrm{~nm})$. As principais transições no NIR $\left(\left.\left.{ }^{4}\right|_{11 / 2} \rightarrow{ }^{4}\right|_{15 / 2} \mathrm{e}\right.$ $\left.\left.\left.{ }^{4}\right|_{13 / 2} \rightarrow{ }^{4}\right|_{15 / 2}\right)$ e VIS $\left(\left.{ }^{2} \mathrm{H}_{11 / 2} \rightarrow{ }^{4}\right|_{15 / 2}\right.$ e $\left.{ }^{4} S_{3 / 2} \rightarrow{ }^{4} 1_{15 / 2}\right)$ estão indicadas nas figuras. FE (free-exciton) refere-se ao sinal de PL devido ao substrato de silício cristalino. Da mesma forma, os picos identificados por astericos dizem respeito ao sinal Raman do substrato de cSi.

O manuscrito é concluído mencionando o grande potencial do sistema a-SiN+Er ${ }^{3+}$ : em aplicações fotônicas (compatibilidade com a tecnologia do silício, possibilidade de extração de radiação VIS e NIR eficiente e com alta resolução espectral), e como eventual sonda de temperatura. Este trabalho foi complementado pela investigação de novas séries de amostras (envolvendo diferentes concentrações de Er, nitrogênio, hidrogênio, e oxigênio), pela realização de tratamentos térmicos, e por medidas de foto-luminescência em função da temperatura, cujos resultados foram publicados em 1999 [60] - ver quadro a seguir.

\section{Visible photoluminescence from $\mathrm{Er}^{3+}$ ions in a-SiN alloys}

A.R. Zanatta, M.J.V. Bell, and L.A.O. Nunes, Physical Review B 59, 10091 (1999)

Abstract - Thin films of Er-doped amorphous SiN (a-SiErN) alloys have been prepared by cosputtering under different deposition conditions. Infrared absorption, Raman scattering, and photoluminescence spectroscopy were employed for characterization purposes. The strongest $\mathrm{Er}^{3+}$-related emissions in the a-SiErN films take place at $\sim 525,550$, and $1540 \mathrm{~nm}$, corresponding to the $\left.{ }^{2} \mathrm{H}_{11 / 2} \rightarrow{ }^{4}\right|_{15 / 2}$, $\left.{ }^{4} S_{3 / 2} \rightarrow{ }^{4}\right|_{15 / 2}$, and $\left.{ }^{4}\right|_{13 / 2} \rightarrow{ }_{155 / 2}$ transitions, respectively. Sample characterization pointed out interesting features following the photon excitation energy, Er concentration, and thermal anneals which are directly related to the electronic structure of the a-SiErN films. Based on these experimental data some mechanisms associated with the $\mathrm{Er}^{3+}$-ion excitation and recombination are proposed and discussed in detail. The present study demonstrates that $\mathrm{Er}^{3+}$ ions in combination with the wide-band-gap a-SiN semiconductor allow the achievement of very narrow green light emission at room temperature. In addition to the potential applications of SiEr-based compounds in the infrared energy region (light sources, detectors, optical amplifiers, etc.), the present results enlarge the perspectives of their use in the construction of monochromatic large-area flat-panel displays, visible light-emitting diodes, temperature sensors, etc.

Além de confirmar os resultados anteriores, este trabalho permitiu chegar às seguintes conclusões: (a) qualquer que seja a composição das amostras de a-SiN+Er ${ }^{3+}$, a forma mais eficiente de se extrair radiação 
devida aos íons $\mathrm{Er}^{3+}$ é mediante excitação com fótons de $488.0 \mathrm{~nm}$, os quais populam diretamente o nível ${ }^{4} \mathrm{~F}_{7 / 2}$ (processo de excitação quase-ressonante); (2) para as amostras (e concentrações) consideradas, uma alta fração de íons $\mathrm{Er}^{3+}$ favorece a absorção de fótons em $488.0 \mathrm{~nm}$ aumentando a emissão associada ao $\mathrm{Er}^{3+}$, em detrimento daquela relativa à matriz de a-SiN $(\mathrm{H})$; (3) 0 tratamento térmico das amostras de a-SiN+Er ${ }^{3+}$ aumenta sensivelmente a intensidade do sinal de PL (em 1540, 550, e $525 \mathrm{~nm}$ ), fato que está associado à redução do número de centros de recombinação não-radiativos; (4) medidas de PL em função da temperatura indicam a existência de diferentes mecanismos associados à emissão do íon $\mathrm{Er}^{3+}$ nas regiões do VIS e do NIR - esta última sendo muito mais sensível aos detalhes da matriz; e (5) estes aspectos ficam muito mais evidentes quanto maior a concentração de oxigênio presente nas amostras.

Muito embora estivesse claro que, devido à coincidência do nível ${ }^{4} \mathrm{~F}_{7 / 2} \mathrm{com}$ a energia de fótons com 488 $\mathrm{nm}$, a excitação dos íons $\mathrm{Er}^{3+}$ ocorria de forma quase-ressonante, 0 trabalho seguinte tratou exclusivamente desta questão [61] - ver quadro a seguir. Enquanto nos trabalhos anteriores $[48,60]$ as amostras de a-SiN+E ${ }^{3+}$ foram excitadas com um laser de $\mathrm{Ar}^{+}(514.5,488.0$ e $457.9 \mathrm{~nm})$, no presente caso foram realizadas medidas de PL convencional (excitação em 514.5, 488.0, 476.0 e 363.8 nm), e medidas de foto-luminescência de excitação PLE (photoluminescence excitation) nas regiões: 770-840 nm (laser Ti:sapphire), 630-680 nm (laser de corante - DCM dicyanomethylene), e 530-560 nm (laser de corante - Coumarin). As medidas de PLE foram realizadas levando-se em consideração a emissão em $1540 \mathrm{~nm}$ devida à transição $\left.\left.{ }^{4}\right|_{13 / 2} \rightarrow{ }^{4}\right|_{15 / 2}$ dos íons $\mathrm{Er}^{3+}$. As Figuras 13 e 14 ilustram alguns dos resultados deste trabalho.

\section{Optical excitation of Er3+ ions in a-SiN alloys}

M.J.V. Bell, L.A.O. Nunes, and A.R. Zanatta, Journal of Applied Physics 86, 338 (1999)

Abstract - Photoluminescence excitation spectroscopy was carried out on the $\left.4\right|_{13 / 2} \rightarrow 4_{15 / 2}$ transition from Er-doped amorphous siliconnitrogen thin film alloys (a-SiN). The sample was prepared by cosputtering of a Si target partially covered with Er pellets. It is demonstrated that Er $3^{+}$ions may be excited by direct sharp-line intra-4f-shell absorption as well as by energy transfer from the a-SiN matrix. The effects of temperature and possible energy transfer mechanisms to Er ions are presented and discussed.

A Figura 13(a), por exemplo, apresenta 0 espectro de transmissão óptica da amostra de a-SiN+Er ${ }^{3+}$ considerada (bandgap óptico $4 \mathrm{eV}$ ), assim como indicações dos comprimentos de onda utilizados para excitação com um laser de $\operatorname{Ar}^{+}(363.8,476.0,488.0$, e $514.5 \mathrm{~nm})$ e as posições relativas de alguns dos níveis de energia associados ao ín $\mathrm{Er}^{3+}$. A partir desta figura fica evidente que a amostra de a-SiN+Er ${ }^{3+}$ transmite, ao menos, 75\% de toda radiação fornecida pelo laser de Ar+. Ainda assim, é possível observar o sinal de PL (à temperatura ambiente) como resultado de transições ópticas na região do visível [Figura 13(b)] e infra-vermelho próximo [Figura 13(c)] devidas ao íon $\mathrm{Er}^{3+}$. Os sinais de $\mathrm{PL}$ observados referem-se às seguintes transições: $\left.{ }^{2} \mathrm{H}_{11 / 2} \rightarrow{ }^{4}\right|_{15 / 2}(\mathrm{em} \sim 525 \mathrm{~nm}),\left.{ }^{4} \mathrm{~S}_{3 / 2} \rightarrow{ }^{4}\right|_{15 / 2}(\mathrm{em} \sim 550 \mathrm{~nm}),\left.\left.{ }^{4}\right|_{11 / 2} \rightarrow{ }^{4}\right|_{15 / 2}(\mathrm{em} \sim 980 \mathrm{~nm})$, e $\left.\left.{ }^{4}\right|_{13 / 2} \rightarrow{ }^{4}\right|_{15 / 2}(\mathrm{em} \sim 1540$ nm) [16]. Além destes, vale mencionar a contribuição de PL devida à matriz do a-SiN (banda larga em 550 $\mathrm{nm}$ ), e correspondente ao substrato de c-Si (sinal em $\sim 1130 \mathrm{~nm}$ ). É interessante notar, também, que mesmo na condição de excitação não-ressonante (fótons em 514.5 e 476.0 nm), a intensidade do sinal de PL é não nula, chegando a ser $\sim 5$ vezes menos intensa que nos outros casos (excitação em 363.8 e $488.0 \mathrm{~nm}$ ). Isto deve-se à absorção de fótons pela matriz do a-SiN (essencialmente devida à presença de defeitos) e ao fato de os íons $\mathrm{Er}^{3+}$ serem centros de recombinação muito eficientes [15,29]. Dito de outra maneira, ainda que 0 sinal de PL possa ser obtido para todos os comprimentos de onda utilizados, aqueles que apresentam coincidência 
com os níveis do íon Er ${ }^{3+}$ produzem os melhores efeitos: 363.8 nm com o nível ${ }^{2} K_{15 / 2}$ e 488.0 nm com o nível ${ }^{4} \mathrm{~F}_{7 / 2}$.
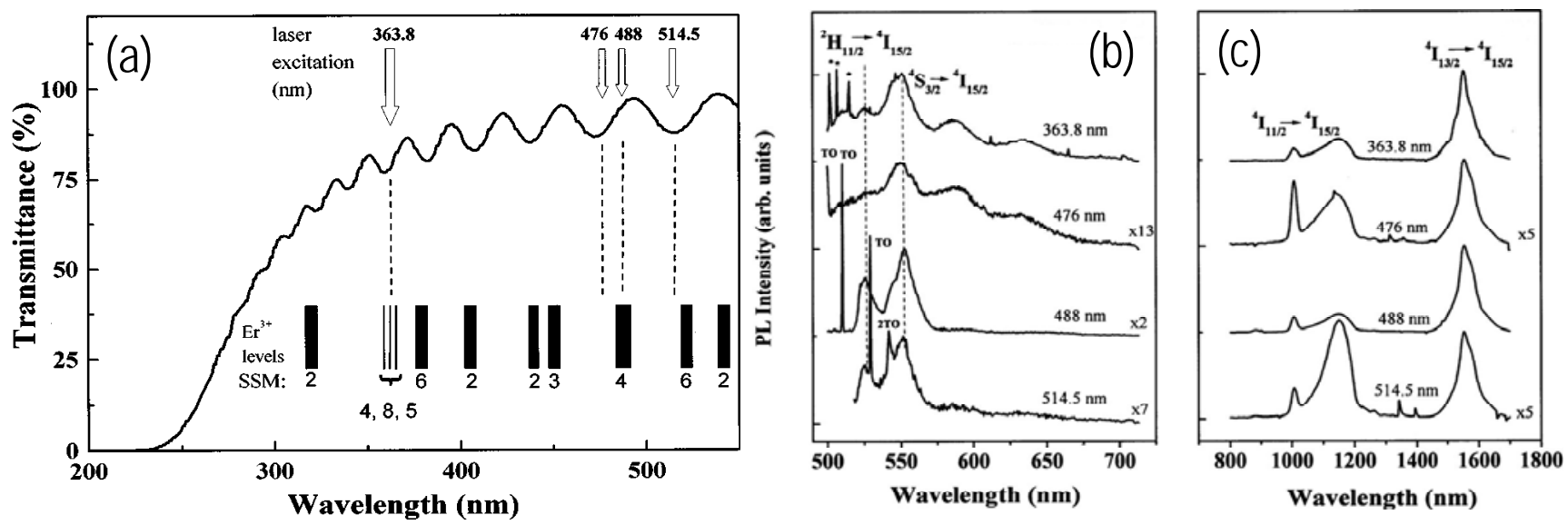

Figura 13 - Espectros, obtidos à temperatura ambiente, de um filme de a-SiN dopado com Er: (a) transmissão óptica entre 200 e 550 nm, (b) foto-luminescência (PL) na região do visível ( 500-700 nm), e (c) PL na região do infra-vermelho próximo ( 800-1700 nm). Em (a) temos indicados os comprimentos de onda utilizados para excitação e a posição dos níveis eletrônicos associados ao íon Er ${ }^{3+}$. SSM corresponde a Stark splitting manifold. Em (b) e (c) estão indicadas as principais transições devidas ao $\mathrm{E}^{3+}$. TO e 2TO denotam os sinais Raman (transverso óptico) devidos ao substrato de silício cristalino.

Alguns espectros de PLE em função da temperatura de medida, juntamente com um diagrama de níveis de energia do íon $\mathrm{Er}^{3+}$, estão representados na Figura 14.
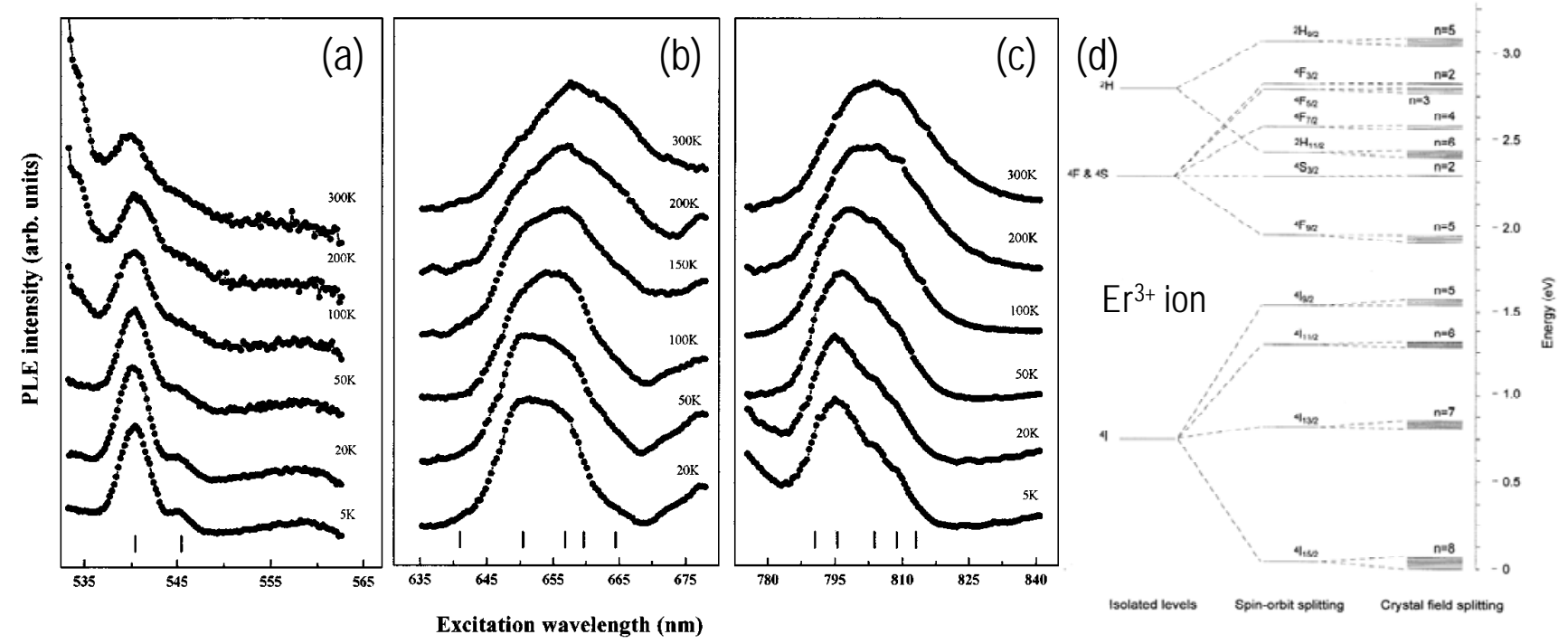

Figura 14 - Espectros de foto-luminescência de excitação PLE, obtidos a diferentes temperaturas, de um filme de a-SiN dopado com Er nas seguintes regiões: (a) 535-565 nm correspondente à transição $\left.{ }^{4}\right|_{15 / 2} \rightarrow{ }^{4} S_{3 / 2}$, (b) 635-675 nm (transição $\left.{ }^{4}\right|_{15 / 2} \rightarrow{ }^{4} \mathrm{~F}_{9 / 2}$ ), e (c) 780-840 nm (transição $\left.{ }^{4}\right|_{15 / 2} \rightarrow{ }^{4} l_{9 / 2}$ ). Na parte inferior das figuras temos representadas as posições dos níveis eletrônicos ${ }^{4} S_{3 / 2}$, ${ }^{4} \mathrm{~F}_{9 / 2}$, e $\left.{ }^{4}\right|_{9 / 2}$ com suas respectivas separações spin-órbita (Stark splitting) - conforme ilustradas em (d). 
Os resultados de PLE são extremamente ilustrativos e nos levam às seguintes considerações: (a) ainda

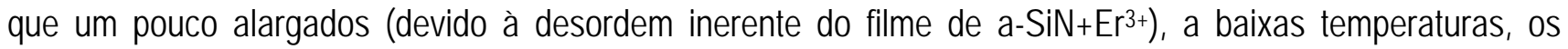
espectros possuem grande semelhança com a disposição dos níveis eletrônicos do íon $\mathrm{Er}^{3+}$ separados pelo efeito de acoplamento spin-órbita (Stark splitting); (2) além da absorção de fótons pelos íons $\mathrm{Er}^{3+}$, os espectros de PLE são influenciados pela presença de defeitos na matriz do a-SiN (com contribuições em comprimentos de onda $<535$, $>675$, e $<780 \mathrm{~nm}$, por exemplo); (3) com o aumento da temperatura de medida, praticamente todos os espectros tornam-se mais alargados devido a contribuições vibracionais ou de fônons; e (4) esta também é a origem do red-shift experimentado pelos espectros de PLE uma vez que as componentes Stark mais energéticas do estado fundamental $\left(44_{15 / 2}\right)$ passam a ser populadas com elétrons.

Tendo por base os resultados de PLE, o trabalho discute ainda a impossibilidade de se atribuir um sítio específico para 0 íon $\mathrm{Er}^{3+}$ na matriz do a-SiN, justamente em função da estrutura desordenada deste. Não obstante esta limitação, fica claro a partir do estudo realizado que radiação luminosa nas regiões do visível e do infra-vermelho próximo pode ser eficientemente gerada a partir do sistema a-SiN+Er ${ }^{3+}$. Ainda que o processo de excitação direta (quase-ressonante) produza os melhores resultados, o sinal de luminescência dos íons $\mathrm{Er}^{3+}$ quando excitados via matriz amorfa é não-desprezível. Isto sugere que o sistema a-SiN+E r $^{3+}$ pode servir de base para a confecção de dispositivos eletro-luminescentes de forma a expandir, ainda mais, as perspectivas deste material em aplicações fotônicas. A bem da verdade, este tipo de dispositivo foi produzido recentemente, com grande sucesso, por um grupo de pesquisadores da Boston University [62].

Os trabalhos que se seguiram, buscaram explorar a excitação do a-SiN com elétrons (catodoluminescência ou $\mathrm{CL}$ ) bem como a inserção de diferentes íns terra-rara. Além destas questões, aspectos relacionados à passivação de dangling bonds de Si devido à presença de íons $\mathrm{RE}^{3+} \mathrm{e}$ as propriedades fotoelétricas destes também foram considerados.

Dentre os trabalhos envolvendo a excitação com elétrons (CL) vale destacar uma publicação de 2001 [63] - ver quadro a seguir, onde foram explorados os mecanismos de excitação dos íons $\mathrm{Er}^{3+} \mathrm{e} \mathrm{Sm}^{3+}$ quando inseridos na matriz do a-SiN.

\section{Visible luminescence from a-SiN films doped with $\mathrm{Er}$ and $\mathrm{Sm}$}

A.R. Zanatta, C.T.M. Ribeiro, and U. Jahn, Applied Physics Letters 79, 488 (2001)

Abstract - Relatively strong and narrow red and green light emission has been achieved from amorphous (a-) SiN films independently doped with $\mathrm{Er}^{3+}$ and $\mathrm{Sm}^{3+}$ ions. The films were deposited by cosputtering a Si target partially covered with small pieces of metallic $\mathrm{Er}$ (and $\mathrm{Sm}$ ) in an atmosphere of pure nitrogen. As a consequence of the deposition method and conditions, the films have an amorphous structure, and contents of $\mathrm{Er}$ (and $\mathrm{Sm}$ ) in the low 0.5 at.\%. All characterizations were accomplished on as-deposited samples and at room temperature and included: ion-beam analysis (Rutherford backscattering spectrometry and nuclear reaction analysis) and optical techniques (light absorption, Raman scattering, and photoluminescence and cathodoluminescence). A detailed examination of the experimental results allowed the identification of all luminescence features existing in the films.

A Figura 15 apresenta os espectros de PL e de CL obtidos dos filmes de a-SiN:Er e a-SiN:Sm, bem como um diagrama esquemático dos níveis de energia dos íons $\mathrm{Er}^{3+} \mathrm{e} \mathrm{Sm}^{3+}$. Os resultados de um filme de a-SiN nãodopado também são apresentados para fins comparativos. As principais contribuições observadas nos espectros referem-se aos íon $\mathrm{Er}^{3+}$ e $\mathrm{Sm}^{3+}$ e correspondem às seguintes transições [16], conforme indicado na Fig. 15(c): $\left.\operatorname{Er} 1(\sim 520 \mathrm{~nm}){ }^{2} \mathrm{H}_{11 / 2} \rightarrow{ }^{4}\right|_{15 / 2} ;\left.\mathrm{Er} 2(\sim 550 \mathrm{~nm}){ }^{4} \mathrm{~S}_{3 / 2} \rightarrow{ }^{4}\right|_{15 / 2} ;\left.\mathrm{Er} 3(\sim 660 \mathrm{~nm}){ }^{4} \mathrm{~F}_{9 / 2} \rightarrow{ }^{4}\right|_{15 / 2} ; \operatorname{Er} 4(\sim 390$ $\mathrm{nm}){ }^{4} \mathrm{G}_{11 / 2} \rightarrow{ }^{4} 1_{15 / 2} ; \mathrm{Er} 5(\sim 410 \mathrm{~nm}){ }^{2} \mathrm{H}_{9 / 2} \rightarrow{ }^{4} 1_{15 / 2} ; \mathrm{Sm} 1(\sim 560 \mathrm{~nm}){ }^{4} \mathrm{G}_{5 / 2} \rightarrow{ }^{6} \mathrm{H}_{5 / 2} ; \mathrm{Sm} 2(\sim 600 \mathrm{~nm}){ }^{4} \mathrm{G}_{5 / 2} \rightarrow{ }^{6} \mathrm{H}_{9 / 2} ; \mathrm{Sm} 3$ 
$(\sim 650 \mathrm{~nm}){ }^{4} \mathrm{G}_{5 / 2} \rightarrow{ }^{6} \mathrm{H}_{9 / 2}$. As transições $\left.{ }^{4}\right|_{15 / 2} \rightarrow{ }^{4} \mathrm{~F}_{7 / 2}$ e $\left.{ }^{6} \mathrm{H}_{5 / 2} \rightarrow{ }^{4}\right|_{9 / 2}$ relativas aos íons $\mathrm{Er}^{3+}$ e $\mathrm{Sm}^{3+}$, respectivamente, também estão indicadas na Fig. 15(c), e apresentam grande coincidência com o comprimento de onda utilizado durante as medidas de PL (488.0 nm).

(a)

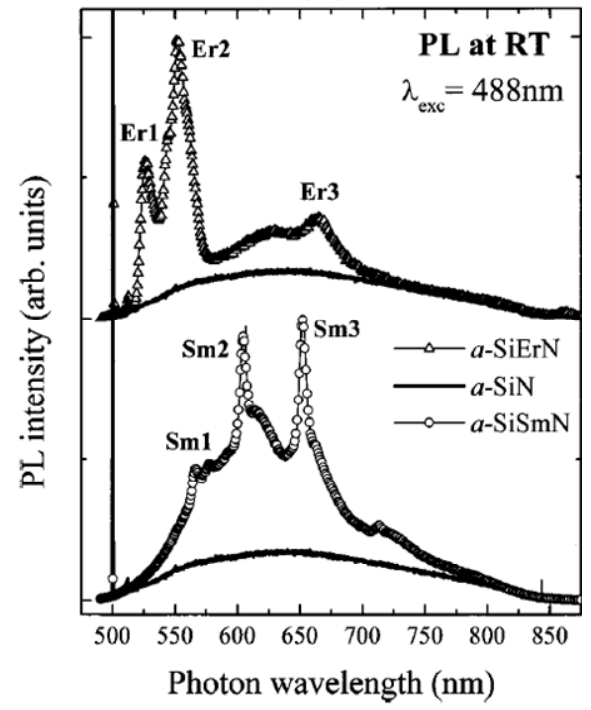

(b)

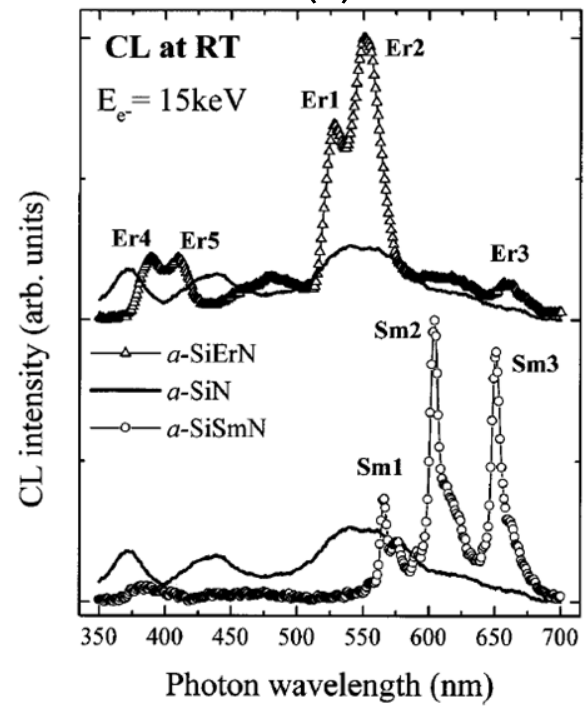

(c)
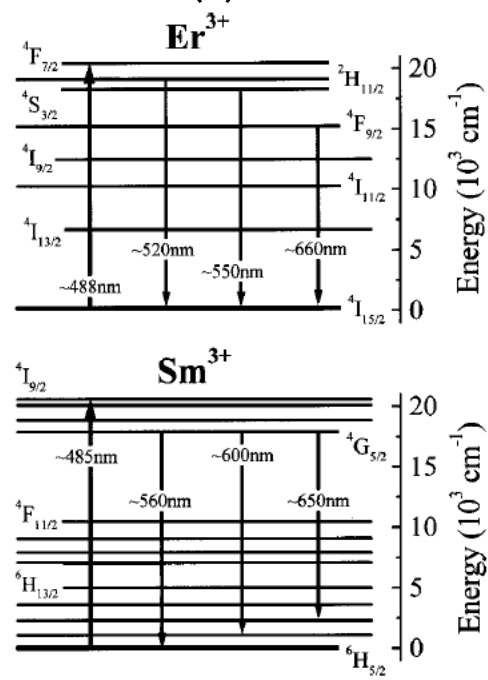

Figura 15 - Espectros de foto-luminescência PL (a) e de catodo-luminescência CL (b) obtidos de filmes de a-SiN dopados com Er e Sm. Os espectros foram obtidos à temperatura ambiente mediante excitação com fótons de $488.0 \mathrm{~nm}(\mathrm{PL})$ e elétrons de $15 \mathrm{keV}(\mathrm{CL})$. Para fins comparativos, os espectros devidos a filmes de a-SiN não-dopados também são apresentados. Em (c) temos um diagrama esquemático dos níveis de energia dos íons $\mathrm{Er}^{3+} \mathrm{e} \mathrm{Sm}^{3+}$.

Além da possibilidade de medidas com alta resolução espacial $\left(<1 \mu \mathrm{m}^{2}\right)$, a técnica de $C L$ é ideal para testar com rapidez a compatibilidade de materiais em aplicações como fontes de luz excitadas eletricamente (LED- light emitting diode, por exemplo). Quanto ao mecanismo de excitação por $\mathrm{CL}$, sabemos que ocorre (prioritariamente) por impacto eletrônico e que depende da densidade de pares elétron-buraco $e-h$ gerada [64]. Esta densidade, e consequente produção do sinal de $\mathrm{CL}$, pode ser aproximada pela perda de energia dos elétrons primários que apresenta um máximo em $\sim 0.3 R_{\kappa o}-$ com $R_{k o}$ sendo a extensão de penetração de Kanaya-Okayama [65]. Tendo por base estas informações, uma estimativa grosseira nos diz que os fótons produzidos por $\mathrm{CL}$ tem origem em uma profundidade de até $\sim 600 \mathrm{~nm}$. Levando-se em conta a espessura dos filmes de a-SiN $(\sim 500 \mathrm{~nm})$, fica claro o porquê da presença de pequenas contribuições devidas ao substrato de c-Si nos espectros de CL [Fig. 15(b)]: ressonância de volume associada ao menor bandgap óptico direto do c-Si $(\sim 370 \mathrm{~nm})$, e transições envolvendo defeitos ( 435 e $630 \mathrm{~nm})$. Além destas, o sinal de $\mathrm{CL}$ em $\sim 550 \mathrm{~nm}$ é semelhante àquele verificado em c-Si após oxidação térmica em atmosfera seca [66] e, muito provavelmente, deve ser originário do c-Si.

Feitas as devidas atribuições espectroscópicas, vale dizer que os espectros de PL e CL da Figura 15 são muito parecidos, exceto pelos seguintes detalhes: ausência de sinal de PL com comprimentos de onda menores que $\sim 500 \mathrm{~nm}$, e ausência de qualquer contribuição devida à matriz de a-SiN (banda alargada entre 550-750 nm) nos espectros de CL. Enquanto a primeira das diferenças é uma limitação da energia de excitação ( $2.5 \mathrm{eV}$ ou $488.0 \mathrm{~nm}$ no caso da PL), a segunda característica requer maior discussão. Ao contrário 
do caso cristalino, a energia de limiar de dano causado por elétrons é consideravelmente menor nos materiais amorfos [64]: $10^{2} \mathrm{keV}$ versus $1 \mathrm{keV}$, respectivamente. Além disto, a exposição a um feixe de elétrons pode causar defeitos que não são possíveis com fótons com energias, tipicamente, na região do UV-VIS. Estes defeitos adicionais (essencialmente ligações quebradas e deslocações atômicas) atuam como centros de recombinação não-radiativa e reduzem consideravelmente a eficiência de luminescência em um semicondutor amorfo, fazendo com que o seu sinal de CL seja muito fraco ou, até mesmo, inexistente. Some-se a isto, o fato de os íons $\mathrm{RE}^{3+}$ serem centros de recombinação muito eficientes, que competirão com outros centros (radiativos ou não), dentro da matriz de um semicondutor amorfo. Como resultado, quando sujeitos a um feixe de elétrons de $15 \mathrm{keV}$, muitos dos pares $e-h$ recombinar-se-ão, preferencialmente, através dos íons $\mathrm{RE}^{3+}$. Quando a excitação é feita por fótons o mecanismo é diferente. Ainda que os íons $\mathrm{RE}^{3+}$ sejam excitados de forma quase-ressonante, parte dos fótons em $488.0 \mathrm{~nm}$ pode ser absorvida pela matriz do a-SiN e dar origem a pares $e-h$. Dos pares assim gerados, aqueles que não recombinarem de forma não-radiativa, podem transferir a sua energia aos íons $\mathrm{RE}^{3+}$ ou à matriz do a-SiN para, então, darem origem ao sinal de PL. Dentro deste contexto, a emissão de PL devida à matriz do a-SiN parece ser mais efetiva no caso dos filmes de a-SiN:Sm o que pode estar associado à disposição dos níveis energéticos do $\mathrm{Sm}^{3+}$ e/ou à interação entre este e os defeitos da matriz do a-SiN. Os resultados experimentais obtidos com a realização deste trabalho ajudaram a avançar, ainda mais, a compreensão dos mecanismos de excitação-recombinação dos íons RE ${ }^{3+}$. Também foram importantes na medida em que demonstraram a possibilidade de se extrair radiação luminosa RGB (redgreen-blue) de filmes de a-SiN:RE ${ }^{3+}$ sem qualquer tipo de tratamento térmico e, à temperatura ambiente. As investigações que se seguiram levaram em consideração novos íons $\mathrm{RE}^{3+}$ [67], com especial atenção para 0 $\mathrm{Nd}^{3+}[68]$ - ver quadros a seguir.

\section{Photon and electron excitation of rare-earth-doped amorphous SiN films}

A.R. Zanatta, C.T.M. Ribeiro, and U. Jahn, Journal of Non-Crystalline Solids 338-340, 473 (2004)

Abstract - Room temperature visible photo and cathodoluminescence have been achieved from amorphous (a-)SiN films independently doped with $\mathrm{Pr}^{3+}, \mathrm{Sm}^{3+}$, $\mathrm{Dy}^{3+}, \mathrm{Ho}^{3+}$, and $\mathrm{Er}^{3+}$ ions. The films were deposited by co-sputtering a Si target partially covered with metallic rare-earth (RE) in an atmosphere of pure nitrogen. As a consequence of the deposition method and conditions, the films have an amorphous structure and RE contents of 0.5 at.\%, as determined by Raman scattering and ion beam analysis, respectively. The luminescence experiments were carried out in films, typically $0.5 \mu \mathrm{m}$ thick, after excitation with either $488.0 \mathrm{~nm}$ photons or $15 \mathrm{keV}$ electrons. All characterizations were accomplished at room temperature and on as-deposited samples. A detailed investigation of the luminescence spectra allowed the identification of all existing optical features and indicates possible RE ion excitation-recombination mechanisms. In addition to the importance of Si in modern (micro-)electronics, the current experimental findings suggest the potential of RE-doped SiN compounds to opto-electronic devices operating in the visible energy range.

\section{Spectroscopic study of Nd-doped amorphous SiN films}

C.T.M. Ribeiro, M. Siu Li, and A.R. Zanatta, Journal of Applied Physics 96, 1058 (2004)

Abstract - Neodymium-doped amorphous silicon-nitrogen (a-SiN) thin films have been prepared by cosputtering a Si+Nd target in a nitrogen atmosphere. After deposition the films were submitted to cumulative thermal annealing treatments and investigated in detail by Raman scattering spectroscopy, optical transmission, x-ray photoelectron spectroscopy (XPS), and photoluminescence techniques. Additional information was also obtained from ion beam analyses such as Rutherford backscattering spectrometry and nuclear reaction analysis. As a result of the deposition method and conditions, the films are amorphous and contain $\sim 0.8$ at.\% of neodymium. Actually, Raman scattering measurements indicate that the present films remain amorphous even after thermal anneal at $1000{ }^{\circ} \mathrm{C}$. The electronic states at the top of the valence band of the Nd-doped a-SiN films were investigated by XPS, which indicates that most of the neodymium present in the a-SiN host stays under the trivalent $\left(\mathrm{Nd}^{3+}\right)$ form. As a consequence, relatively strong and well-defined 
photoluminescence signal could be observed in the infrared energy range corresponding to internal $4 f$ transitions due to the $\mathrm{Nd}^{3+}$ ions. The achievement of this optical emission is highly susceptible both to the thermal annealing treatment and to the energy of photon excitation. Whereas the former determines the atomic environment of the $\mathrm{Nd}^{3+}$ ions, the latter indicates the most efficient route to their optical excitation. Based on various experimental techniques, and as a result of a systematic investigation, the present manuscript contains an extended and comprehensive discussion on the principal spectroscopic characteristics of the Nd-doped amorphous SiN system.

Ao mesmo tempo em que novas amostras (envolvendo composições e/ou íons distintos) eram preparadas, um aspecto que sempre se fez presente nas pesquisas realizadas no LFF refere-se à utilização de diferentes e variadas técnicas de caracterização experimental. Desta forma, e sempre que possível, os sistemas investigados tiveram as propriedades ópticas-eletrônicas associadas a detalhes composicionais, estruturais (ou morfológicos), etc. Das técnicas complementares utilizadas, devemos destacar a de espectroscopia de fotoemissão (XPS- $x$-ray photoelectron spectroscopy) que permitiu a investigação dos níveis de energia associados aos elétrons do topo da banda de valência e de orbitais internos dos elementos RE [69] - ver quadro a seguir. Além de completamente original, este trabalho permitiu a análise dos estados eletrônicos do topo da banda de valência do a-SiN+RE, dando claras evidências de que, neste sistema, os íons RE ocorrem prioritariamente sob a forma triplamente ionizada $\mathrm{RE}^{3+}$ (Figura 16). A única exceção observada refere-se ao Yb, que pode assumir simultaneamente as formas $\mathrm{Yb}^{3+}$ e $\mathrm{Yb}^{2+}$ - aspecto também verificado em medidas de $\mathrm{PL}$ [70].

\footnotetext{
X-ray photoelectron spectroscopy study of rare-earth-doped amorphous silicon-nitrogen films

A.R. Zanatta, C.T.M. Ribeiro, and F. Alvarez, Journal of Applied Physics 93, 1948 (2003)

Abstract - Amorphous silicon-nitrogen (a-SiN) films independently doped with different rare-earth (RE) elements ( $\mathrm{Y}, \mathrm{La}, \mathrm{Pr}, \mathrm{Nd}, \mathrm{Sm}$, $\mathrm{Gd}, \mathrm{Tb}, \mathrm{Dy}, \mathrm{Ho}, \mathrm{Er}, \mathrm{Tm}, \mathrm{Yb}$, and $\mathrm{Lu}$ ) have been prepared by cosputtering. The films were investigated in detail by x-ray photoelectron spectroscopy employing $1486.6 \mathrm{eV}$ photons. Additional information was also achieved by optical techniques and ion beam analyses. As a result of the deposition method and conditions, the films present similar contents of $\mathrm{Si}$ and $\mathrm{N}$, and rare-earth concentrations below 1.0 at.\%. In spite of this relatively low concentration, and taking advantage of the high photoionization cross section of the rare-earth elements at $1486.6 \mathrm{eV}$, the signal of several different core-levels and Auger transitions could be detected and analyzed. The electronic states at the top of the valence band of the RE-doped a-SiN films were also investigated with $1486.6 \mathrm{eV}$ photons. Compared to the spectroscopic data of pure metals, the RE-related core levels of the present a-SiN films exhibit an energy shift typically in the $0.8-2.5$ $\mathrm{eV}$ range, which is attributed to the presence of nitrogen atoms. According to the experimental data, most of the RE ions remain in the $3+$ state. The only clear exception occurs in the $\mathrm{Yb}$-doped a-SiN film, where a large fraction of $\mathrm{Yb}^{2+}$ coexisting with $\mathrm{Yb}^{3+}$ ions is evident.
} 


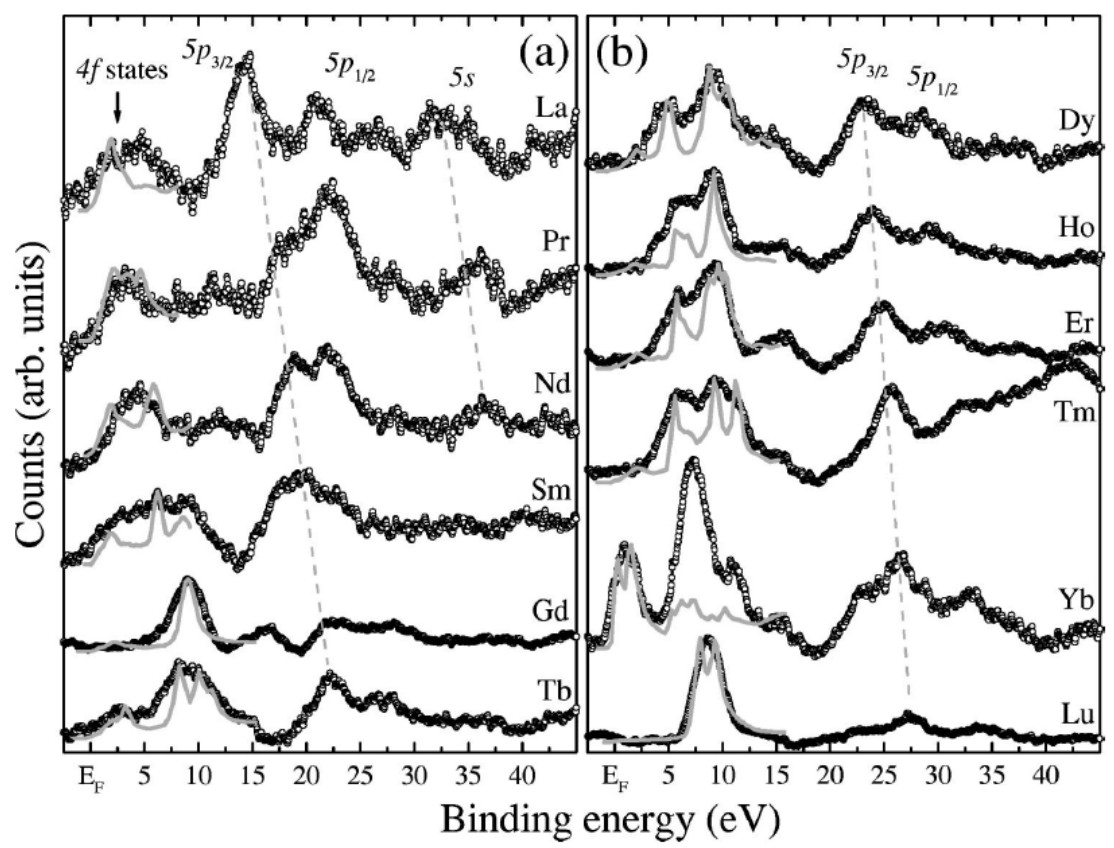

Figura 16 - Espectros de foto-emissão (XPS) relativos ao topo da banda de valência de filmes de a-SiN dopados com La, Pr, Nd, Sm, Gb, Tb, Dy, Ho, Er, Tm, Yb, e Lu. Os espectros devidos aos elementos RE sob a forma metálica estão indicados por linhas cinza.

Outro trabalho, igualmente original, e que explorou 0 efeito da presença de íons $\mathrm{RE}^{3+}$ sobre a densidade de defeitos do a-SiN foi realizado [71] - ver quadro a seguir. A técnica utilizada para investigar 0 efeito foi a de ressonância de spin eletrônico (ESR- electron spin resonance) e concluiu que: os elementos RE encontram-se sob a forma $\mathrm{RE}^{3+}$, e que a densidade de dangling bonds neutras presentes no a-SiN é drasticamente reduzida quando íons $\mathrm{RE}^{3+}$ magnéticos estão presentes. Resultados semelhantes foram obtidos no sistema a-Si:H+RE ${ }^{3+}$ (com diferentes composições e estruturas atômicas), levando a crer que a redução na densidade de defeitos no sistema Si+RE ${ }^{3+}$ se dá a partir de uma interação do tipo de troca entre os spins dos íons $\mathrm{RE}^{3+}$ magnéticos e das dangling bonds neutras de Si [72].

\section{Neutral dangling bond depletion in amorphous $\mathrm{SiN}$ films induced by magnetic rare-earth elements} M.S. Sercheli, C. Rettori, and A.R. Zanatta, Solid State Communications 128, 47 (2003)

Abstract - Amorphous silicon-nitrogen (a-SiN) thin films doped with rare-earth elements (RE = Y, La, Pr, Nd, Sm, Gd, Tb, Dy, Ho, Er, $\mathrm{Yb}$, and $\mathrm{Lu}$ ) were prepared by cosputtering and studied by means of electron spin resonance. It was found that the neutral dangling bond density [ $\left.\mathrm{D}^{0}\right]$ of the a-SiN films decreases with the presence of magnetic REs and the drop in [D ${ }^{0}$ approximately scales with the de Gennes and/or the spin factor of each RE element. Similar to the decrease in $T_{c}$ in RE-doped superconductors, our experimental results strongly suggest that an exchange-like interaction, $\mathcal{H}_{\sim} \sim \mathrm{J}_{\mathrm{RE}-\mathrm{D} O} \mathrm{~S}_{\mathrm{RE}}$. $\mathrm{S}_{\mathrm{DO}}$, between the spin of the magnetic REs and that of the $\mathrm{D}^{0}$ is taking place.

Dos trabalhos mais recentes deve-se mencionar um detalhado estudo espectroscópico do a-SiN dopado com os íons $\mathrm{Sm}, \mathrm{Tb}$, Tm e suas combinações ( $\mathrm{Sm}+\mathrm{Tb}$ e $\mathrm{Sm}+\mathrm{Tb}+\mathrm{Tm}$ ) [73] - ver quadro a seguir. Baseado em resultados experimentais de absorção e de emissão (PL e CL) óptica, o manuscrito investiga os mecanismos de excitação dos íns $\mathrm{RE}^{3+}$ (e suas combinações) e discute sobre as condições ideais para a obtenção de componentes do tipo RGB a partir do sistema a-SiN+RE ${ }^{3+}$. 


\section{Red-green-blue light emission and energy transfer processes in amorphous SiN films doped with Sm and Tb}

A.R. Zanatta, A. Khan, and M.E. Kordesch, Journal of Physics: Condensed Matter 19, 436230 (2007)

Abstract - Amorphous silicon-nitrogen (a-SiN) thin films have been independently doped with $\mathrm{Sm}, \mathrm{Tb}$, and $\mathrm{Sm}+\mathrm{Tb}$. The films were prepared by reactive cosputtering and characterized by energy dispersive x-ray analysis, optical transmission, and photo- and cathodoluminescence techniques. All films display room temperature visible luminescence after excitation with either photon or electron sources. The present results indicate that the luminescence intensity is highly susceptible to thermal annealing treatments as well as to the combination of rare-earth ions. In fact, an improvement of about $500 \%$ was achieved in the overall optical emission after annealing the films up to $1050^{\circ} \mathrm{C}$ for $15 \mathrm{~min}$. Also, the presence of $\mathrm{Tb}^{3+}$ ions in the $\mathrm{Sm}+\mathrm{Tb}$-doped a-SiN films enhanced the $\mathrm{Sm}^{3+}$ related emission, and spectrally sharp optical transitions could be verified at 485,545 , and $650 \mathrm{~nm}$. The likely mechanisms behind the optical activation of the $\mathrm{Sm}^{3+}$ and $\mathrm{Tb}^{3+}$ ions and the energy transfer processes between these ions and the amorphous SiN matrix, are presented and discussed. In order to improve the blue light emission of the present samples, one a-SiN film simultaneously doped with $\mathrm{Sm}+\mathrm{Tb}+\mathrm{Tm}$ has also been prepared and investigated in detail.

Como principais conclusões deste trabalho, podemos destacar: (1) tratamentos a temperaturas crescentes, qualquer que seja o íon (ou íons) considerado(s), levam ao aumento do sinal de luminescência como resultado da diminuição de processos não-radiativos presentes na matriz do a-SiN; (2) comparados aos filmes dopados com Sm, Tb, ou Sm+Tb, aqueles dopados com Sm+Tb+Tm apresentam menor intensidade de PL; e (3) emissão de luz, relativamente intensa e bem-resolvida, pode ser obtida do sistema a-SiN:Sm${ }^{3+}+\mathrm{Tb}^{3+}+\mathrm{Tm}^{3+} \mathrm{em}^{2}$ $\sim 650$ (red), 545 (green), 470 nm (blue), e no infra-vermelho ( 790 nm) - ver Figura 17.

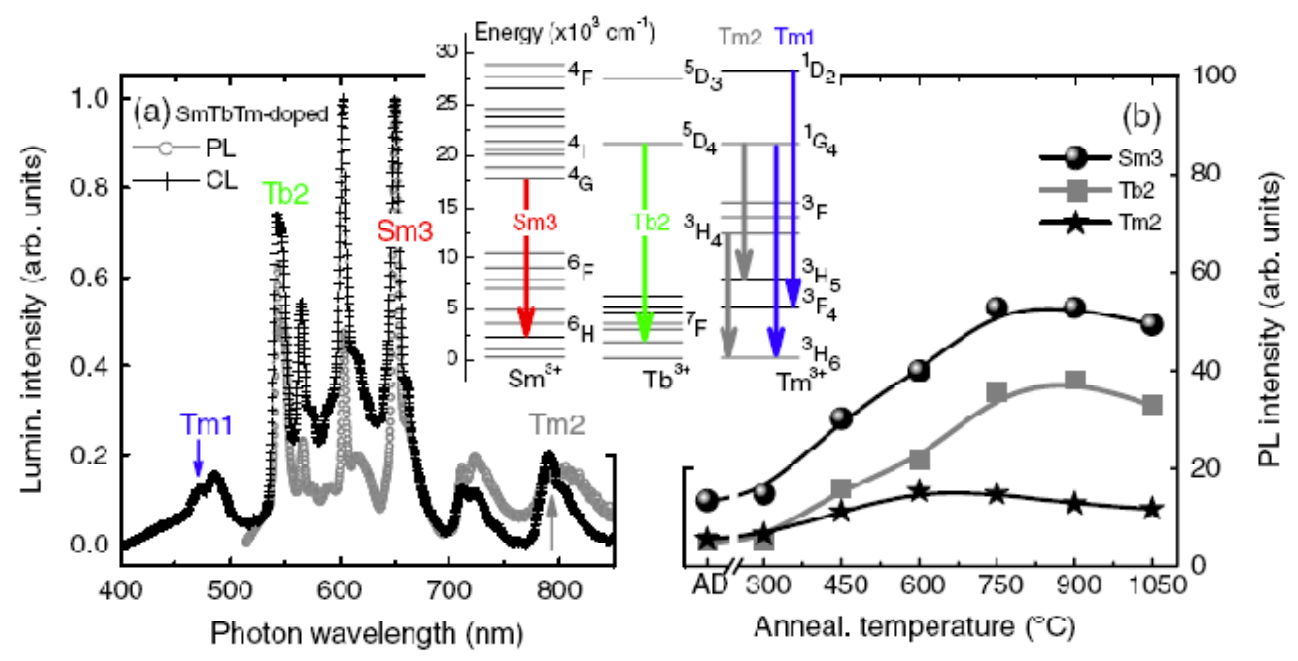

Figura 17 - (a) Espectros de foto- (PL) e catodo-luminescência (CL), obtidos à temperatura ambiente, de um filme de a-SiN dopado com Sm+Tb+Tm. (b) Valores da intensidade de PL em função da temperatura de tratamento térmico (cumulativo, por 15 min), para as transições Sm3 $\left(\sim 650 \mathrm{~nm},{ }^{4} \mathrm{G}_{5 / 2} \rightarrow{ }^{6} \mathrm{H}_{9 / 2}\right)$, Tb2 $\left(\sim 545 \mathrm{~nm},{ }^{5} \mathrm{D}_{4} \rightarrow{ }^{7} \mathrm{~F}_{5}\right)$, e Tm2 $\left(\sim 790 \mathrm{~nm},{ }^{1} \mathrm{G}_{4} \rightarrow{ }^{3} \mathrm{H}_{5}\right.$ ou $\left.{ }^{3} \mathrm{H}_{4} \rightarrow{ }^{3} \mathrm{H}_{6}\right)$, conforme indicadas no diagrama.

Em paralelo aos estudos realizados sobre 0 a-SiN+RE ${ }^{3+}$ outras classes de filmes finos amorfos também foram investigadas: a-GaAsN, a-AIN, a-GeN, dentre outros. Neste caso, ainda que não perfeitamente compatíveis com a tecnologia do silício, as pesquisas tiveram como propósito a obtenção de informações complementares e, principalmente, o desenvolvimento de novos materiais emissores de luz. De maneira 
análoga ao trabalho feito no a-Si:H e no a-SiN, todos os materiais considerados foram preparados pela técnica de rf cosputtering, submetidos a diferentes tipos de tratamento pós-deposição, e investigados por uma série de técnicas experimentais. Passemos à descrição dos principais sistemas considerados.

\section{Parte 3 - Outros materiais}

\section{A - Filmes de a-GaAsN}

Tendo como motivação o estudo de materiais de bandgap grande foram investigados filmes produzidos a partir de um alvo de GaAs e uma atmosfera de $A r+N_{2}$. A inserção de íons $\mathrm{Er}^{3+}$ deu-se durante o processo de deposição e a proporção da mistura gasosa $A r+N_{2}$ foi intencionalmente variada a fim de induzir alterações sistemáticas no bandgap do material. Os resultados deste estudo foram objeto de uma publicação em 1999 [74] - ver quadro a seguir, e apresentados em uma conferência internacional [75].

\section{$1540 \mathrm{~nm}$ light emission from Er-doped amorphous GaAsN films}

A.R. Zanatta, Applied Physics Letters 75, 3279 (1999)

Abstract - Erbium-doped amorphous gallium-arsenic-nitrogen (a-GaAsN) films have been prepared by cosputtering from a crystalline GaAs wafer partially covered with metallic Er pieces. The films were deposited at room temperature under different partial pressures of $\mathrm{Ar}$ and $\mathrm{N}_{2}$. After deposition, the films were characterized by optical transmission in the visible-ultraviolet energy range, photoluminescence $(\mathrm{PL})$ in the infrared region, and Raman scattering spectroscopy. Compositional measurements were also performed indicating an Er content of $\sim 0.5$ at.\% and a $\mathrm{N}$ concentration that scales with the $\mathrm{N}_{2}$ partial pressure during deposition. According to the experimental results, to higher $\mathrm{N}$ contents correspond larger optical band gaps and more intense $\mathrm{Er}^{3+}{ }^{3+}$ related $\mathrm{PL}$ signals. This dependence is analyzed in terms of the compositional, electronic, and structural characteristics of each film.
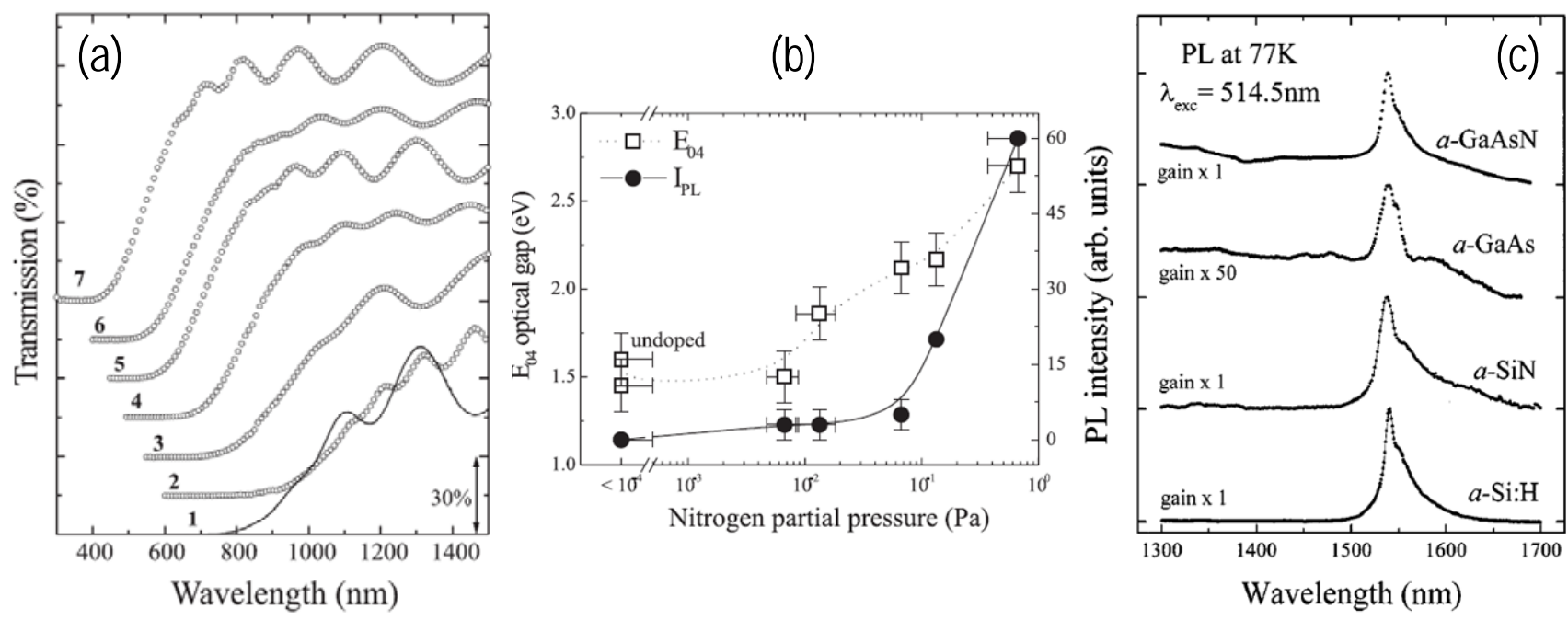

Figura 18 - (a) Espectros de transmissão óptica ( 300-1500 nm) referentes a filmes de a-GaAs (1- não-dopado, e 2- dopado com Er), e de a-GaAsN com concentrações crescentes de nitrogênio e dopado com Er. (b) Valores de bandgap óptico ( $E_{04}$ ) e de intensidade de $\mathrm{PL} \mathrm{a} \sim 1540 \mathrm{~nm}$ (devida à transição $\left.{ }^{4}\right|_{13 / 2} \rightarrow{ }^{4}{ }_{15 / 2}$ dos íons $\mathrm{Er}^{3+}$ ) em função da pressão de $\mathrm{N}_{2}$ utilizada durante 0 processo de deposição. (c) Espectros de PL ilustrando o sinal devido aos íons $\mathrm{Er}^{3+}$ em diferentes filmes: a-GaAsN, a-GaAs, a-SiN, e a-Si:H.

Basicamente, e em estreita correlação com o trabalho a respeito da extinção do sinal de PL [59], foi possível verificar a dependência da intensidade de emissão devida aos íons Er ${ }^{3+}$ (em 1540 nm) com 0 
bandgap óptico do a-GaAsN. Este aspecto pode ser apreciado através dos resultados presentes na Figura 18, onde está clara a influência da pressão de $\mathrm{N}_{2}$ utilizada durante as deposições (e consequente concentração de nitrogênio nos filmes) e as variações no bandgap óptico $\mathrm{E}_{04} \mathrm{e}$ intensidade de $\mathrm{PL}$ devida aos íons $\mathrm{Er}^{3+}$.

Esta série de filmes de a-GaAsN teve, ainda, a sua composição e características estruturais investigada em detalhe. Medidas de XPS (x-ray photoelectron spectroscopy) e de XAES (x-ray excited Auger spectroscopy) permitiram avaliar 0 efeito de concentrações crescentes de nitrogênio na matriz do a-GaAsN mediante 0 estudo das energias de elétrons associados ao Ga e ao As, bem como de suas transições Auger LMM [76] - ver quadro a seguir. Em particular, foi possível estabelecer o deslocamento químico experimentado pelos níveis eletrônicos do Ga e do As em função da concentração de átomos nitrogênio, como também verificar a ligação preferencial Ga-N nas amostras de a-GaAsN ricas em nitrogênio.

\section{Photoelectron spectroscopic study of amorphous GaAsN films}

A.R. Zanatta, P. Hammer, and F. Alvarez, Applied Physics Letters 76, 2211 (2000)

Abstract - Amorphous gallium-arsenic-nitrogen (a-GaAsN) thin films were deposited by sputtering a crystalline GaAs target with different mixtures of argon and nitrogen. X-ray photoelectron spectroscopy (XPS) and x-ray excited Auger electron spectroscopy (XAES) were employed to study the $\mathrm{Ga}$ and As core levels and the corresponding LMM Auger transitions of films with different $\mathrm{N}$ concentrations. Chemical information of these samples was obtained through the analysis of the Auger parameter, which is exempt from problems inherent in the interpretation of XPS and XAES shifts, revealing aspects associated with the composition of the aGaAsN films. In particular, these experimental results show the preferential bonding of $\mathrm{N}$ to $\mathrm{Ga}$ atoms in the formation of $\mathrm{N}$-rich amorphous GaAsN films.

Sob o ponto de vista composicional-estrutural, os filmes de a-GaAsN foram investigados pelas técnicas de RBS (Rutherford backscattering spectrometry), NRA (nuclear reaction analysis), ERDA (elastic recoil detection analysis), espalhamento Raman, e absorção óptica [77] - ver quadro a seguir.

\section{Optoelectronic and structural properties of Er-doped sputter-deposited gallium-arsenic-nitrogen films}

A.R. Zanatta, C.T.M. Ribeiro, and F.L. Freire Jr., Journal of Applied Physics 90, 2321 (2001)

Abstract - Erbium-doped gallium-arsenic-nitrogen thin films were prepared by cosputtering a crystalline GaAs target partially covered with small pieces of metallic erbium in an $\mathrm{Ar}+\mathrm{N}_{2}$ atmosphere. The films were deposited near room temperature and under increasing partial pressures of nitrogen $\mathrm{P}\left(\mathrm{N}_{2}\right)$. The investigation of the films included ion beam analysis, optical spectroscopy in the infraredvisible-ultraviolet energy ranges, Raman scattering, and photoluminescence measurements. According to the experimental results, all films present an amorphous structure and nitrogen contents that scale with $\mathrm{P}\left(\mathrm{N}_{2}\right)$. Increasing amounts of nitrogen induce the widening of the optical band gap and a systematic redshift of the Raman signal of the films considered. The intensity of the Er-related light emission at $\sim 0.8 \mathrm{eV}$ also increases at higher nitrogen contents. A detailed study of the absorption bands in the infrared region allowed the identification of different vibration modes involving gallium, arsenic, and nitrogen atoms. The combined analysis of the compositional data and of the infrared absorption bands provided a constant of proportionality between the nitrogen content in the films and the integrated absorption due to $\mathrm{Ga}-\mathrm{N}$ bonds. Where applicable, comparisons between the optoelectronic and structural characteristics of amorphous and crystalline gallium-arsenic-nitrogen compounds were made.

As principais conclusões obtidas neste trabalho foram: (1) a composição química de diferentes filmes de aGaAsN foi determinada pelas técnicas de RBS, NRA, ERDA, e XPS indicando que, uma vez inseridos, os átomos de nitrogênio passam a ocupar as posições associadas aos átomos de As. Isto altera sensivelmente as características ópticas-eletrônicas dos filmes; (2) o bandgap óptico dos filmes de a-GaAsN depende da concentração de nitrogênio, e encontra-se entre 1.5 e $3 \mathrm{eV}$ para a série considerada. A variação encontrada é 
praticamente linear e está em desacordo com o observado em compostos de GaAsN cristalino; (3) concentrações crescentes de nitrogênio induzem um redshift dos modos vibracionais associados às ligações Ga-As (em $\left.250 \mathrm{~cm}^{-1}\right)$. Em função das características do sistema investigado, este efeito pode estar associado ao caráter amorfo ou stress típico das amostras; (4) a análise detalhada dos resultados de absorção no infra-vermelho (FTIR) permitiu a identificação de todos os modos vibracionais presentes nos filmes de aGaAsN os quais, em conjunto com as informações composicionais, permitiram a determinação de constantes de calibração envolvendo as ligações As-H e Ga-N; e (5) experimentos de $\mathrm{PL}$, associados ao conjunto de resultados experimentais, indicaram a presença de transições devidas ao íon $\mathrm{Er}^{3+}(\mathrm{em} \sim 1540 \mathrm{~nm})$ bem como outras associadas a defeitos presentes na matriz do a-GaAsN.

\section{B - Filmes de a-AlN}

$\mathrm{Na}$ busca por novos materiais luminescentes, e informações sobre 0 sistema semicondutor+RE ${ }^{3+}$, outro composto que recebeu grande atenção foi o nitreto de alumínio amorfo (a-AIN). Com um bandgap óptico de aproximadamente $5 \mathrm{eV}$ (mesmo na fase amorfa), e grande resistência térmica e química, filmes de a-AlN têm sido considerados para inúmeras aplicações tecnológicas. Foi estudado em relativo detalhe no LFF e teve suas propriedades ópticas-eletrônicas-estruturais investigadas sob a forma não-dopada [78-80] e contendo diferentes íons terra-rara.

Um dos primeiros estudos envolvendo o sistema a-AlN+RE ${ }^{3+}$ foi publicado em 2002 [81] - ver quadro a seguir, e consistiu na investigação de filmes de a-AIN dopados com Sm. 0 trabalho considerou resultados de PL na região visível, em filmes conforme depositados e em função da temperatura de tratamento térmico. Os mecanismos de transferência de energia envolvendo a matriz do a-AlN e os íons Sm também foram explorados. Como característica marcante, deve-se mencionar a co-existência de íons $\mathrm{Sm}^{3+} \mathrm{e} \mathrm{Sm}^{2+}$ na matriz do a-AlN.

\section{Red and green light emission from samarium-doped amorphous aluminum nitride films}

C.T.M. Ribeiro, F. Alvarez, and A.R. Zanatta, Advanced Materials 14, 1154 (2002)

Abstract - Sm-doped amorphous AIN films have been prepared by the cosputtering technique at temperatures in the low $200{ }^{\circ} \mathrm{C}$. The films are almost stoichiometric and contain a Sm concentration of approx. 3.0 at.\%, as determined by $\mathrm{x}$-ray photoelectron spectroscopy. Photoluminescence measurements were performed at room-temperature by exciting with $488.0 \mathrm{~nm}$ photons. Welldefined and relatively strong red and green light emission associated with Sm ions was observed from as-deposited films. All radiative transitions were identified and the coexistence of $\mathrm{Sm}^{3+}$ and $\mathrm{Sm}^{2+}$ ions in the amorphous AIN matrix was noted. The influence of thermal treatments on the Sm-related luminescence of the present AIN films was also investigated in the $150-1050{ }^{\circ} \mathrm{C}$ temperature range. Annealing the films up to $900{ }^{\circ} \mathrm{C}$ considerably improves the luminescence intensity of all transitions. This phenomenon is tentatively attributed to structural ordering and diffusion of light atomic species. A further increase of the annealing temperature, e.g., to $1050^{\circ} \mathrm{C}$, has the opposite effect on the luminescence signal, considerably decreasing the PL intensity. The temperature dependence of the luminescence intensity was also studied and shows that all transitions, either due to $\mathrm{Sm}^{3+}$ or $\mathrm{Sm}^{2+}$, may have a similar mechanism of photon excitation.

Os resultados obtidos podem ser resumidos nos seguintes itens: (1) filmes de AIN amorfo, dopados com cerca de 3 at.\% de Sm, foram preparados pela técnica de cosputtering; (2) experimentos de PL (com excitação em $488.0 \mathrm{~nm}$ e à temperatura ambiente) revelam a emissão de radiação visível bem definida, em filmes sem qualquer tratamento [Figura 19(a)]; (3) as emissões observadas devem-se à presença de íons $\mathrm{Sm}^{3+} \mathrm{e} \mathrm{Sm}^{2+}$ que são excitados (prioritariamente) de forma quase-ressonante [Figura 19(b)]; (4) quando submetidas a 
tratamentos térmicos até $\sim 900{ }^{\circ} \mathrm{C}$ os filmes de a-AlN+Sm${ }^{3+/ 2+}$ passam a apresentar um aumento de até uma ordem de grandeza na intensidade de $\mathrm{PL}$ - o que é atribuído à difusão de espécies leves e ao re-arranjo parcial da matriz amorfa; (5) medidas de $\mathrm{PL}(\mathrm{T})$ sugerem que os íons $\mathrm{Sm}^{3+}$ e $\mathrm{Sm}^{2+}$ são excitados por mecanismos semelhantes; e (6) muito provavelmente, a co-existência dos íons $\mathrm{Sm}^{3+}$ e $\mathrm{Sm}^{2+}$ deve-se ao caráter parcialmente iônico do AIN.

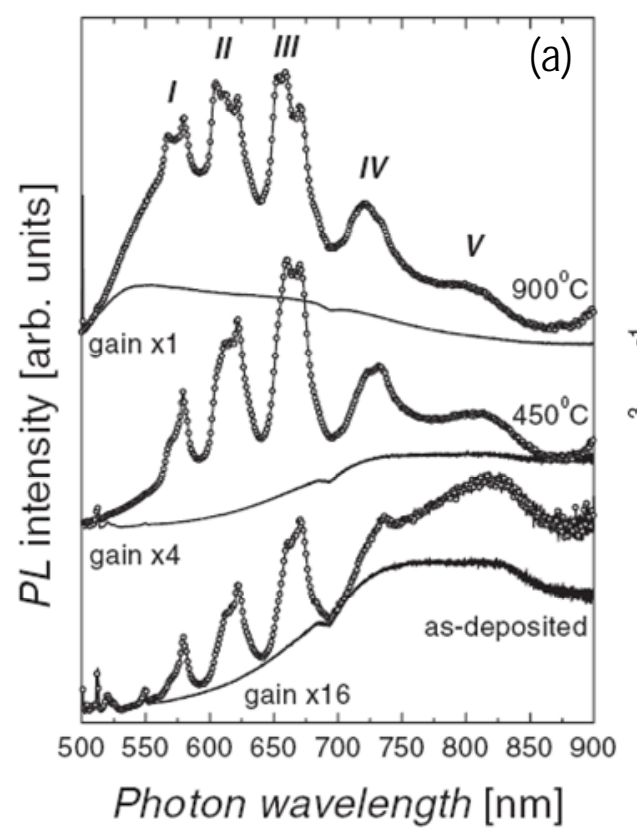

(b)

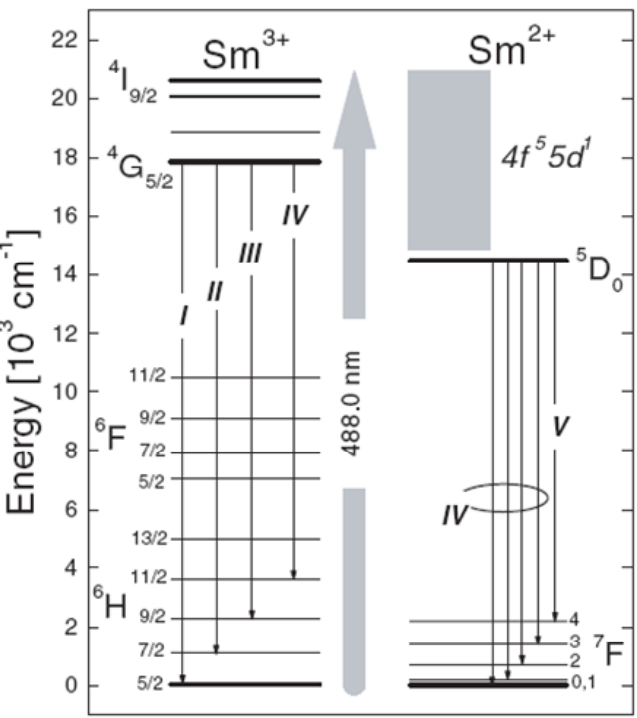

Figura 19 - (a) Espectros de foto-luminescência (excitação 488.0 nm, temperatura ambiente) de filmes de a-AlN não-dopado (linhas) e a-AIN dopado com Sm (símbolos). Os espectros referem-se a filmes sem qualquer tratamento (as-deposited) e após tratamento a 450 e $900{ }^{\circ} \mathrm{C}$ - observe os fatores de escala. (b) Diagrama esquemático dos níveis de energia associados aos íons $\mathrm{Sm}^{3+}$ e $\mathrm{Sm}^{2+}$. As principais transições estão representadas, e correspondem àquelas indicadas em (a).

O sistema a-AlN+Er ${ }^{3+}$ foi considerado em um trabalho posterior e levou em consideração as seguintes técnicas: PL e CL região VIS-NIR ( 200-1700 nm), medidas composicionais (RBS, NRA, e XPS), espalhamento Raman (com excitação em 325.0, 488.0, e 632.8 nm), e absorção óptica nas regiões do UV-VISNIR e IR. Muitos destes resultados foram publicados em 2005 [82] - ver quadro a seguir, e apontaram que: (a) filmes de a-AIN:Er apresentam emissão devida aos íons $\mathrm{Er}^{3+}$, nas regiões VIS e NIR, quando excitados por fótons de $488.0 \mathrm{~nm}$ ou elétrons de $10 \mathrm{keV}$; (b) em função da técnica e das condições de deposição, as amostras permanecem amorfas mesmo após tratamentos até $900{ }^{\circ} \mathrm{C}$; (c) como resultado dos tratamentos térmicos, e consequente alteração da vizinhança local dos íons $\mathrm{Er}^{r^{3+}}$, a intensidade de luminescência é consideravelmente aumentada; (d) muito embora os espectros de PL e de CL apresentem praticamente as mesmas transições associadas aos íons $\mathrm{Er}^{3+}$ [Figura 20(a)-(d)], o sinal de PL é mais sensível aos efeitos da temperatura; (e) os resultados de CL sugerem que a transferência de energia aos íons $\mathrm{Er}^{3+}$ se dá por intermédio de portadores de carga livre; $(f)$ o processo de excitação por elétrons altamente energéticos leva à criação de centros de recombinação não-radiativos nos filmes de a-AIN:Er com consequente redução do sinal de $\mathrm{CL}$ da matriz amorfa; e (g) quando da excitação por fótons, a transferência de energia aos íons $\mathrm{Er}^{{ }^{3+}}$ é basicamente de forma quase-ressonante devido à coincidência entre os níveis ${ }^{4} \mathrm{~F}_{7 / 2}$ e $488.0 \mathrm{~nm}$ [Figura 20(e)]. 


\section{Optoelectronic and structural characteristics of Er-doped amorphous AIN films}

A.R. Zanatta, C.T.M. Ribeiro, and U. Jahn, Journal of Applied Physics 98, 093514 (2005)

Abstract - This work reports on the optical, electronic, and structural properties of aluminum-nitrogen (AIN) films doped with Er. The films were deposited by conventional radio-frequency sputtering at $200{ }^{\circ} \mathrm{C}$ in an atmosphere of pure nitrogen. Their main characteristics have been investigated by experimental techniques such as optical transmission, photo- and cathodoluminescence,

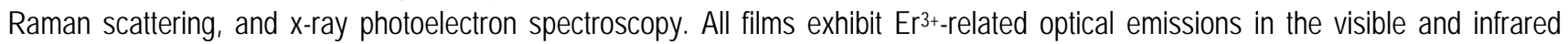
regions, which are considerably enhanced after thermal annealing and on measurements at low temperature. Moreover, Raman spectroscopy indicates that the films remain amorphous even after thermal treatment at $900^{\circ} \mathrm{C}$. Based on the composition and on the structural and luminescent properties of these Er-doped amorphous AIN films it was possible to conclude that energy excitation of $\mathrm{Er}^{3+}$ ions takes place according to different routes when electrons or photons are used. In the former case, energy is transferred from the amorphous host to the $\mathrm{Er}^{3+}$ ions by carrier-mediated processes. As a result, relatively strong $\mathrm{Er}^{3+}$-related optical transitions can be observed in the $\sim 400-1600 \mathrm{~nm}$ range. Excitation with $488.0 \mathrm{~nm}$ photons also produces visible and infrared $\mathrm{Er}^{{ }^{3+}-\text { related luminescence, }}$ but most of the optical excitation occurs through direct excitation of the ${ }^{4} \mathrm{~F}_{7 / 2}$ level of $\mathrm{Er}^{3+}$. Finally, the role played by nitrogen atoms and thermal treatments on the achievement of light emission from the present AIN films is discussed and compared with the existing literature.
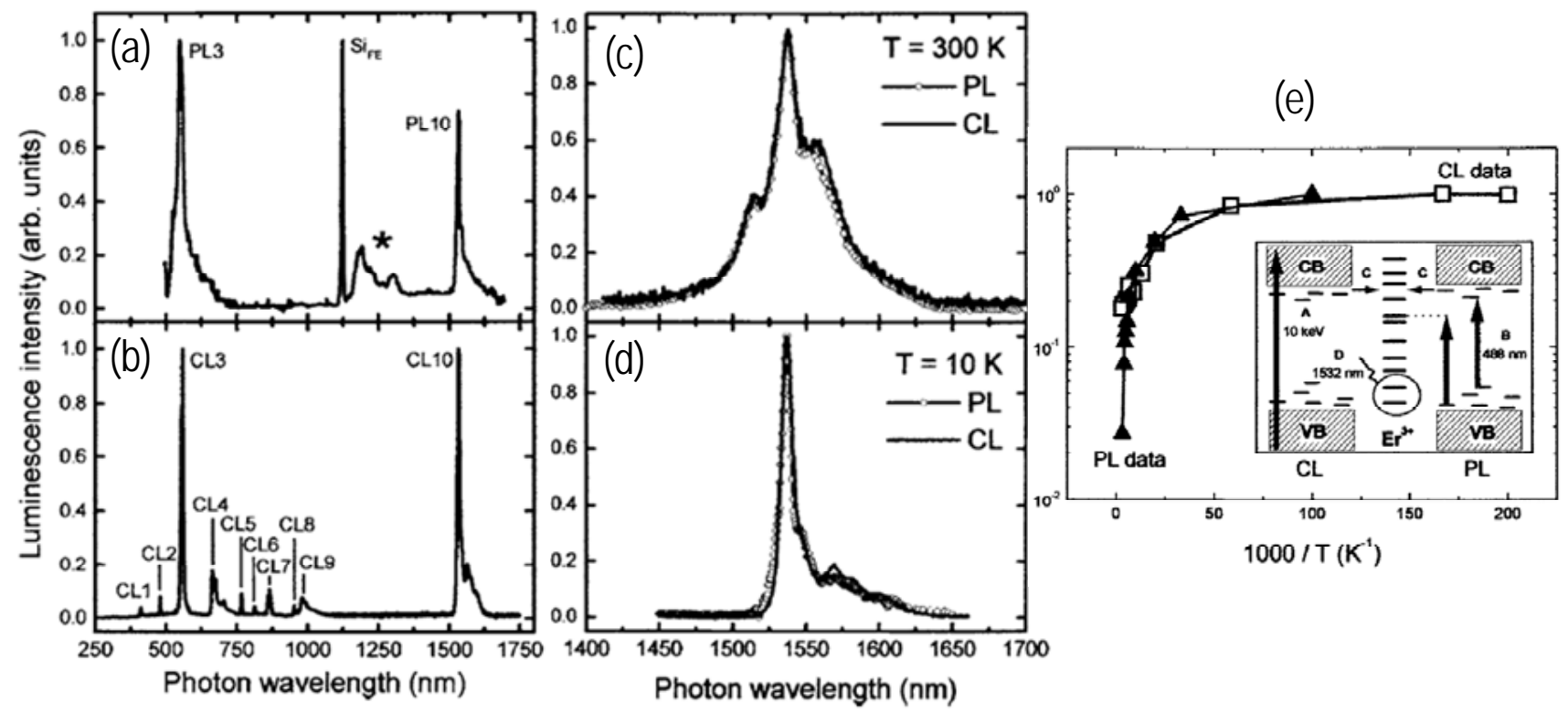

Figura 20 - Espectros de luminescência de um filme de a-AlN dopado com Er: (a) PL a $10 \mathrm{~K}$ (excitação com $488.0 \mathrm{~nm}$ ), (b) CL a 10 K (excitação com $10 \mathrm{keV}$ ), (c) PL e CL à temperatura ambiente, e (d) PL e CL a $10 \mathrm{~K}$. Em (e) temos representada a intensidade de PL e CL em função da temperatura de medida para a transição em $1540 \mathrm{~nm}$. $\mathrm{O}$ insert de (e) contém um diagrama esquemático das bandas de valência (VB) e condução (CB) do a-AIN, bem como os níveis de energia associados ao íon Er ${ }^{3+}$. Os sinais presentes em (a) e em (b) correspondem às seguintes transições (onde GS simboliza o estado fundamental $41_{15 / 2}$ ): CL1 ( $410 \mathrm{~nm},{ }^{2} \mathrm{H}_{9 / 2} \rightarrow \mathrm{GS}$ ), $\mathrm{CL} 2$ $\left(\sim 480 \mathrm{~nm},{ }^{4} \mathrm{~F} / 2 \rightarrow \mathrm{GS}\right), \mathrm{CL} 3$ e PL3 ( $\left.550 \mathrm{~nm},{ }^{4} \mathrm{~S}_{3 / 2} \rightarrow \mathrm{GS}\right), \mathrm{CL} 4\left(\sim 660 \mathrm{~nm},{ }^{4} \mathrm{~F}_{9 / 2} \rightarrow \mathrm{GS}\right), \mathrm{CL} 5\left(\sim 765 \mathrm{~nm},{ }^{2} \mathrm{P}_{3 / 2} \rightarrow{ }^{4} \mathrm{~S}_{3 / 2}\right), \mathrm{CL} 6(\sim 810 \mathrm{~nm}$, $\left.\left.{ }^{4}\right|_{9 / 2} \rightarrow \mathrm{GS}\right), \mathrm{CL} 7\left(\sim 860 \mathrm{~nm},\left.{ }^{4} \mathrm{~S}_{3 / 2} \rightarrow{ }^{4}\right|_{13 / 2}\right.$ ou $\left.\left.{ }^{4}\right|_{9 / 2} \rightarrow \mathrm{GS}\right), \mathrm{CL} 8\left(\sim 950 \mathrm{~nm},\left.{ }^{4} \mathrm{~F}_{7 / 2} \rightarrow{ }^{4}\right|_{11 / 2}\right.$ ou $\left.{ }^{2} \mathrm{P}_{3 / 2} \rightarrow{ }^{4} \mathrm{~F} 7 / 2\right), \mathrm{CL} 9\left(\sim 980 \mathrm{~nm},\left.{ }^{4}\right|_{11 / 2} \rightarrow \mathrm{GS}\right), \mathrm{CL} 10 \mathrm{e}$ PL10 ( $\left.1540 \mathrm{~nm},\left.{ }^{4}\right|_{13 / 2} \rightarrow \mathrm{GS}\right)$.

A questão do ambiente químico experimentado pelos íons $\mathrm{Er}^{3+} \mathrm{e}$ da influência dos tratamentos térmicos foi considerada a partir dos resultados de XPS e de FTIR (Figura 21). No primeiro caso, a análise dos espectros de XPS deixa evidente um deslocamento químico de até $\sim 2$ eV nos orbitais $2 p$ e $2 s$ do alumínio na matriz do a- 
AlN [Figura 21(a)]. Este acréscimo do potencial eletrostático local é responsável pelo alto valor de bandgap óptico do a-AIN [Eg $5 \mathrm{eV}$ - Figura 21(b)], bem como pela alta atividade óptica dos íons $\mathrm{Er}^{3+}$ quando inseridos nesta matriz [59]. A realização de tratamentos a temperaturas crescentes, por outro lado, parece realçar este acréscimo do potencial eletrostático próximo dos íons $\mathrm{Er}^{3+}$ conforme indicado pelas medidas de FTIR. Segundo os resultados experimentais, os tratamentos térmicos provocam um aumento no número de ligações AIN-N em detrimento das ligações Al-N [Figura 21(c)]. Diga-se de passagem, 0 aumento no sinal de luminescência em $1540 \mathrm{~nm}$ apresenta um comportamento semelhante ao apresentado pela razão entre ligações AIN-N e Al-N dando claras evidências da influência da vizinhaça química sobre a atividade óptica dos íons $\mathrm{Er}^{3+}$.

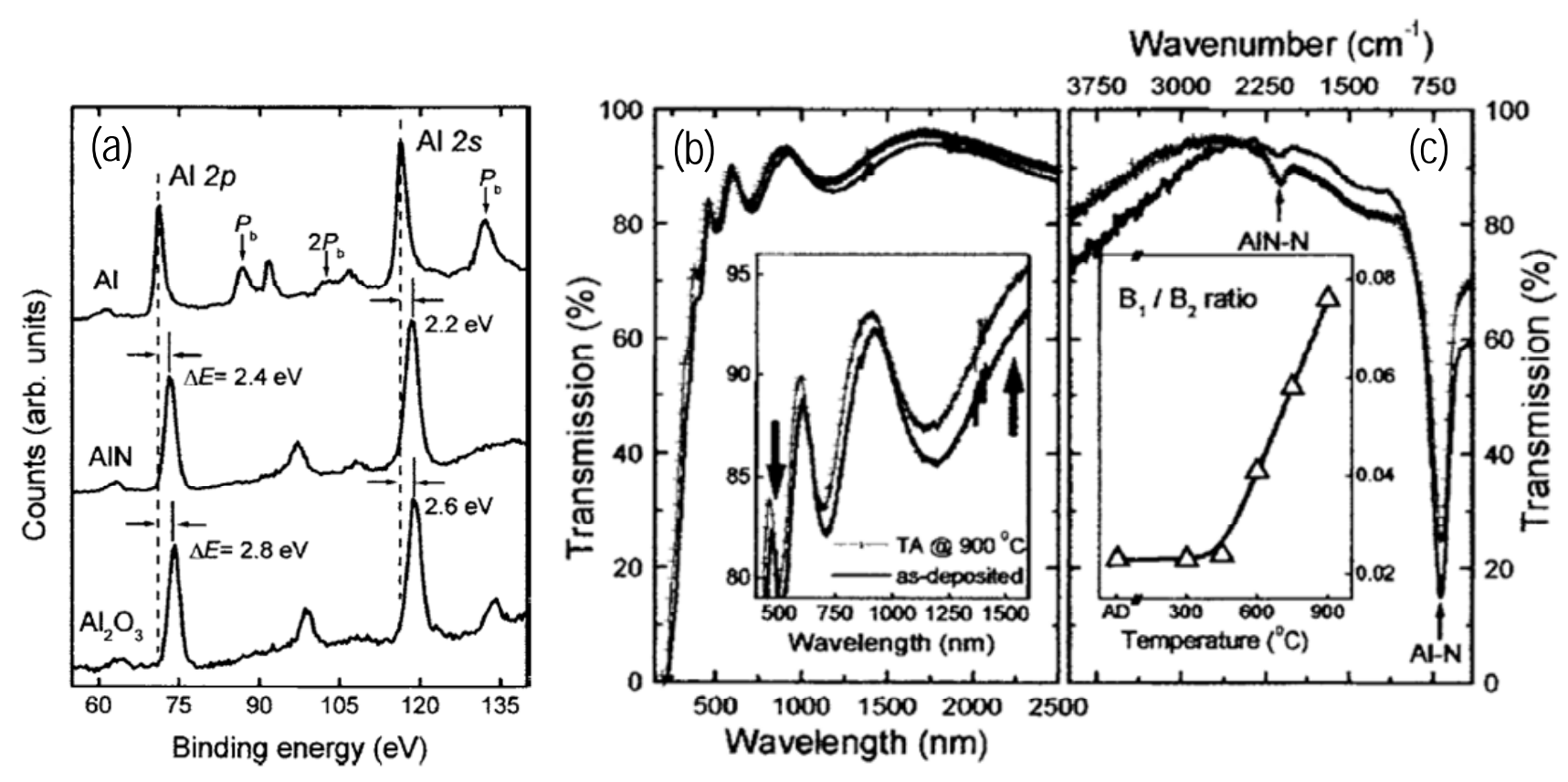

Figura 21 - (a) Curvas de XPS com destaque para os orbitais $2 p$ e $2 s$ do alumínio na forma metálica e nos compostos $\mathrm{AlN}_{\mathrm{N}}$ e $\mathrm{Al}_{2} \mathrm{O}_{3}$. (b) Espectros de transmissão óptica de um filme de a-AIN:Er sem tratamento e após $900{ }^{\circ} \mathrm{C}$. (c) Espectros de transmissão na região do IR ilustrando o efeito da temperatura de tratamento sobre o número de ligações AIN-N e Al-N (razão B1/B2): quanto maior a temperatura, maior a proporção de ligações AIN-N.

A investigação do sistema a-AlN+RE ${ }^{3+}$ teve continuidade mediante o preparo de novas amostras e com 0 estudo de novos íons de interesse acadêmico-tecnológico. Em 2006, por exemplo, foi publicado um trabalho sobre filmes de a-AlN dopados com Tm, Tb, Dy, Eu, Sm, e Yb com emissões relativamente intensas e bem definidas no azul $\left(\mathrm{Tm}^{3+}\right)$, verde $\left(\mathrm{Tb}^{3+}\right)$, amarelo $\left(\mathrm{Dy}^{3+}\right)$, vermelho $\left(\mathrm{Sm}^{3+}\right.$, Eu $\left.{ }^{3+}\right)$, e infra-vermelho $\left(\mathrm{Yb}^{3+}\right)[83]-$ ver quadro a seguir.

Thermal activation, cathodo- and photoluminescence measurements of rare earth doped (Tm, Tb, Dy, Eu, Sm, Yb) amorphous/nanocrystalline AIN thin films prepared by reactive rf-sputtering

R. Weingaertner, O. Erlenbach, A. Winnacker, A. Welt, I. Brauer, H. Mendel, H.P. Strunk, C.T.M. Ribeiro, and A.R. Zanatta, Optical Materials 28, 790 (2006)

Abstract - We present comprehensive cathodo- and photoluminescence measurements from thin amorphous/nanocrystalline (a/nc-) AIN films doped with rare earths. The (a/nc-) AIN films were prepared by reactive rf-sputtering using a high purity $(5 \mathrm{~N})$ aluminium disk 
in high purity nitrogen atmosphere ( $5 \mathrm{~N}$, pressure ca. $1.3 \mathrm{mbar}$ ). The rare earth doping ( $\mathrm{Tm}, \mathrm{Tb}, \mathrm{Dy}, \mathrm{Eu}, \mathrm{Sm}, \mathrm{Yb}$, concentrations were below 1\%) was performed by placing respective rare earth metal pieces of appropriate size onto the aluminium disk. The rare earth ion emissions cover the blue (Tm), green ( $\mathrm{Tb})$, yellow $(\mathrm{Dy})$, red $(\mathrm{Sm}, \mathrm{Eu})$ and infrared $(\mathrm{Yb})$. The optical and related structural properties of the films are correlated by means of high resolution transmission electron microscopy in combination with cathodoluminescence measurements in a scanning electron microscope. In addition, the corresponding compositions are determined by energy-dispersive Xray analysis. The cathodo- and photoluminescence spectra of the rare earth $3+$ ions are recorded in the visible at $300 \mathrm{~K}$ in the asgrown condition ( $\mathrm{Tm}, \mathrm{Tb}, \mathrm{Dy}, \mathrm{Sm}, \mathrm{Eu}, \mathrm{Yb}$ ) and after annealing treatments in the temperature range from 300 to $1100{ }^{\circ} \mathrm{C}$ by steps of $150{ }^{\circ} \mathrm{C}(\mathrm{Tb}, \mathrm{Sm}, \mathrm{Eu}, \mathrm{Yb})$. The anneal-related changes in the cathodo- and photoluminescence emission spectra and in the microstructure of the films are addressed. The AIN films show nanocrystalline structure almost independent of the annealing treatment. Optimal annealing temperature for emissions of Sm and Eu doped (a/nc-) AIN were derived to be $900{ }^{\circ} \mathrm{C}$ whereas $\mathrm{Tb}^{3+}$ and $\mathrm{Yb}^{3+}$ emissions increase at least up to $1100^{\circ} \mathrm{C}$.

Um estudo mais completo, no entanto, detalhando as propriedades ópticas de filmes de a-AIN dopados com íons RE foi publicado em 2009 [84] - ver quadro a seguir. Além de explorar em detalhe os efeitos de tratamentos térmicos sobre as propriedades ópticas dos filmes, o trabalho pretendia investigar a formação de íons $\mathrm{RE}^{2+}$ no a-AIN. Desta forma, o trabalho envolveu o estudo de filmes de a-AIN não-dopados e dopados com $\mathrm{Sm}, \mathrm{Eu}, \mathrm{e} \mathrm{Yb}$.

\section{Effect of thermal annealing treatments on the optical properties of rare-earth-doped AIN films}

A.R. Zanatta, Journal of Physics D: Applied Physics 42, 025109 (2009)

Abstract - Aluminium-nitrogen (AIN) films doped with samarium, europium or ytterbium have been prepared by conventional radio frequency sputtering. Because of the deposition method and conditions the as-deposited films are amorphous with Sm, Eu or $\mathrm{Yb}$ concentrations at low 0.5 at $\%$. After deposition the films were submitted to cumulative isochronal thermal annealing (TA) treatments and investigated by optical transmission spectroscopy, photo- $(\mathrm{PL})$ and cathodoluminescence $(\mathrm{CL})$ measurements. For comparison purposes one undoped AIN film was also prepared and investigated in detail. The experimental results indicate that (a) all samples exhibit PL and CL at room temperature, (b) the main spectral features present in the AIN samples are due to defect-related transitions (undoped film) or the rare-earth (RE) ions, (c) in both cases (undoped and Sm-, Eu- or Yb-doped films) the luminescence intensity scales with the temperature of TA and (d) for the present AIN samples, there is a clear relationship between their luminescence intensity and respective energy of optical bandgaps. Finally, the effect of TA on the excitation-recombination mechanisms involving the RE ions is presented and discussed.

Além de confirmar vários dos resultados obtidos anteriormente, este trabalho foi decisivo em associar os tratamentos térmicos à redução de defeitos na matriz do AIN amorfo, com o consequente aumento na intensidade do sinal de luminescência. As figuras a seguir apresentam alguns dos resultados obtidos com a realização deste trabalho.

Na parte superior da Figura 22 temos representados os espectros de transmissão óptica ( 200-1100 nm) para a série de filmes de a-AIN considerada: sem qualquer tratamento térmico (AD- as-deposited), e após tratamento a 600 e $900{ }^{\circ} \mathrm{C}$. A evolução dos espectros de transmissão óptica deixa evidente que os filmes passam a apresentar uma melhora considerável no limiar de absorção à medida que são submetidos a temperaturas maiores. Isto indica uma redução nos estados de cauda e/ou de defeito cujas principais consequências são: 0 aumento do bandgap óptico, e a redução do número de processos não-radiativos. $\mathrm{Na}$ parte inferior da Figura 22 encontram-se os espectros de PL e de CL, obtidos à temperatura ambiente, da série de filmes de a-AIN sem qualquer tipo de tratamento térmico. Os resultados são bastante ilustrativos e permitem apreciar as transições devidas à matriz do a-AlN e associadas aos íons Sm, Eu, e Yb. 
O efeito dos tratamentos térmicos sobre a intensidade do sinal de PL e do bandgap óptico das amostras investigadas está representado na Figura 23.

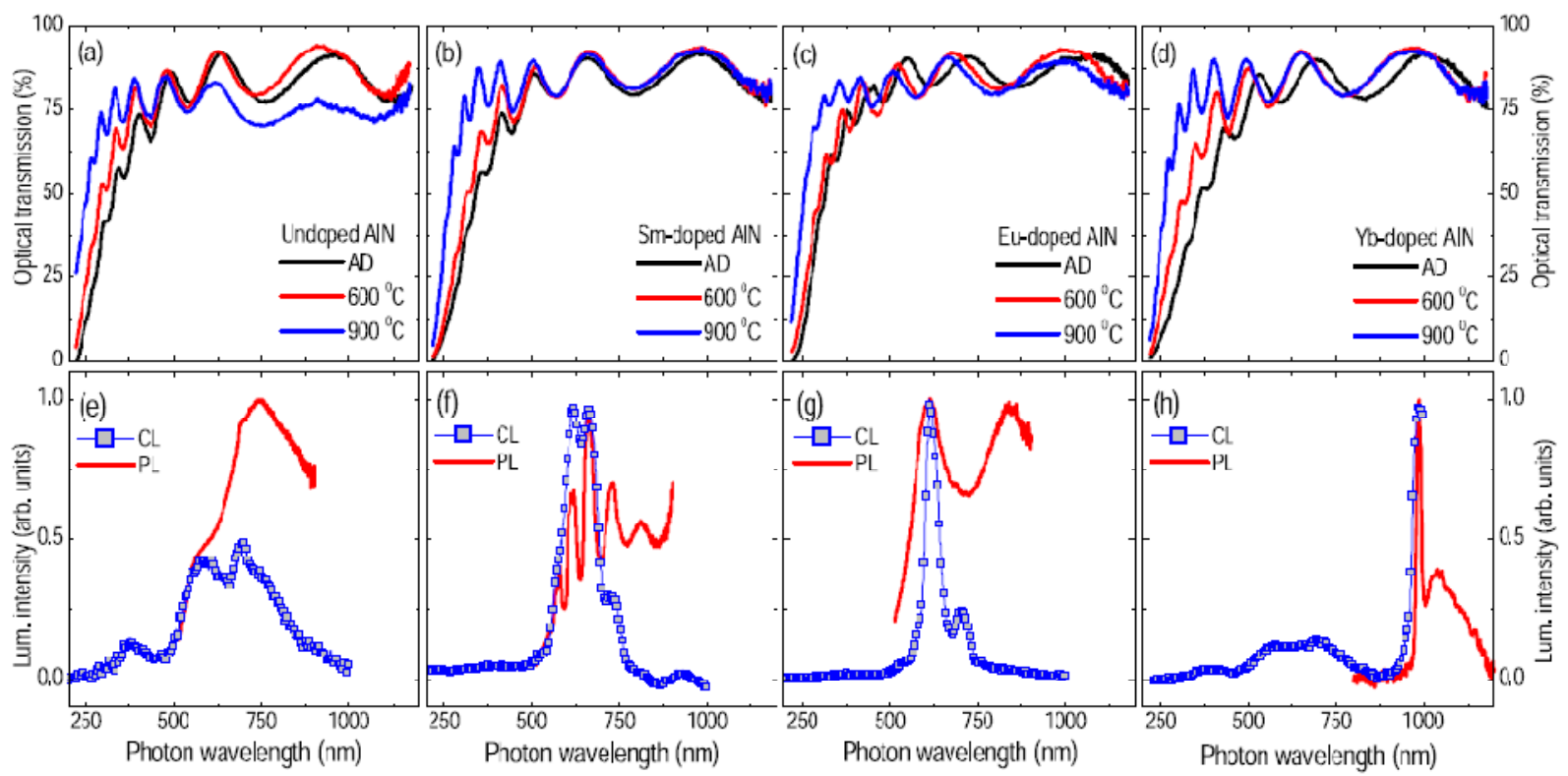

Figura 22 - Espectros de transmissão óptica na região do UV-VIS-NIR ( 200-1100 nm), em função da condição de tratamento de filmes de a-AlN: (a) não-dopado, (b) dopado com Sm, (c) dopado com Eu, e (d) dopado com Yb. Os correspondentes espectros de PL e de $C L$ (obtidos à temperatura ambiente) para os filmes sem qualquer tipo de tratamento estão representados na parte inferior da figura.

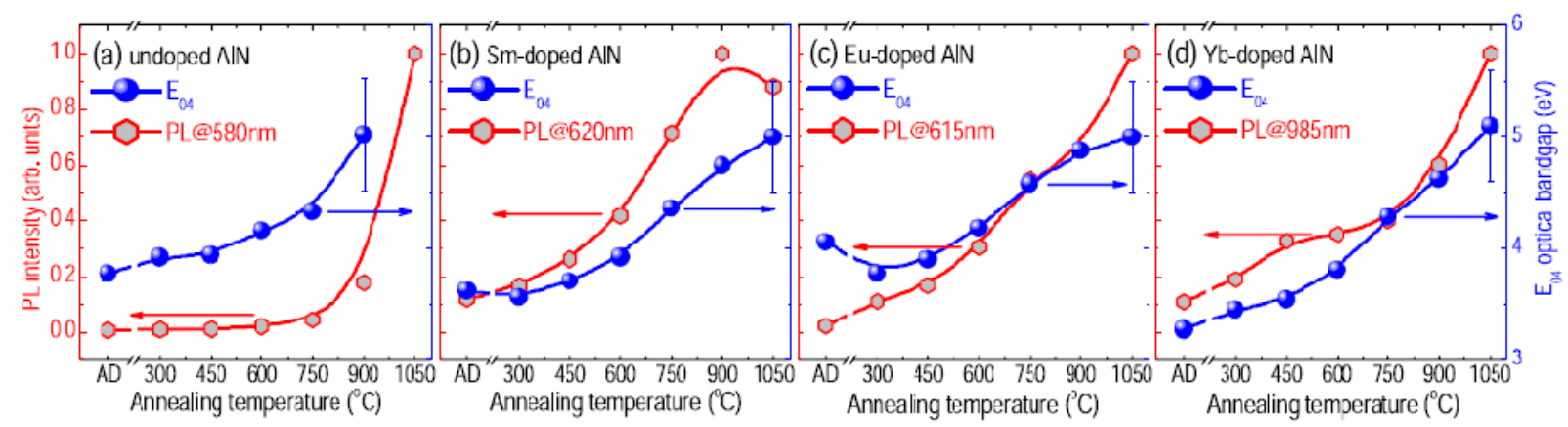

Figura 23 - Intensidade do sinal de PL (nos comprimentos de onda indicados) e bandgap óptico $E_{04}$ em função da temperatura de tratamento térmico para filmes de a-AIN: (a) não-dopado, (b) dopado com Sm, (c) dopado com Eu, e (d) dopado com Yb.

Os resultados apresentados na Figura 23 são conclusivos ao associar a temperatura de tratamento térmico ao aumento do bandgap óptico dos filmes de a-AIN. Tal aumento deve-se à remoção de estados de cauda elou de defeitos presentes na matriz do a-AIN, com o consequente aumento na intensidade de luminescência.

Muito embora não tenha sido possível verificar a formação dos íons $\mathrm{Eu}^{2+} \mathrm{e} \mathrm{Yb}^{2+}, 0$ estudo permitiu explorar em detalhe os mecanismos de excitação-recombinação presentes na série de filmes de a-AIN. Na Figura 24 temos diagramas representando as bandas de valência (VB) e de condução (CB) do a-AlN, dos defeitos presentes no a-AlN, e dos níveis energéticos associados aos íons $\mathrm{Sm}^{3+12+}$, $\mathrm{Eu}^{3+}$, e $\mathrm{Yb}^{3+}$. Também estão indicados os mecanismos de excitação por PL (fótons de $488.0 \mathrm{~nm}$ ) e CL (elétrons de $20 \mathrm{keV}$ ). A partir dos diagramas da Figura 24 ficam evidentes os seguintes aspectos: (a) radiação luminosa pode ser extraída dos 
filmes de a-AIN quando excitados tanto por fótons quanto por elétrons [Figura 22(e)-(h)]; (b) para 0 a-AlN nãodopado, a maior parte das emissões está associada aos defeitos presentes na matriz e/ou a contribuições do substrato de c-Si; (c) para os filmes dopados, a emissão é prioritariamente devida aos íons RE; (d) ainda que a excitação com fótons não seja (quase-)ressonante (exceto pelo ín $\mathrm{Sm}^{3+12+}$ ), os fótons de $488.0 \mathrm{~nm}$ podem ser absorvidos pelo a-AlN e, então, transferidos aos íons; e (e) a alta energia associada à excitação por elétrons inibe a emissão devida à matriz de a-AIN - assim como no caso do sistema a-SiN+RE. Por fim, é curioso notar que enquanto íons de $\mathrm{Sm}^{2+}$ foram indistintamente verificados no a-SiN e no a-AIN, o mesmo não ocorreu para 0 $\mathrm{Yb}^{2+}$ no a-AlN. Este aspecto não está completamente claro e requer maiores investigações.
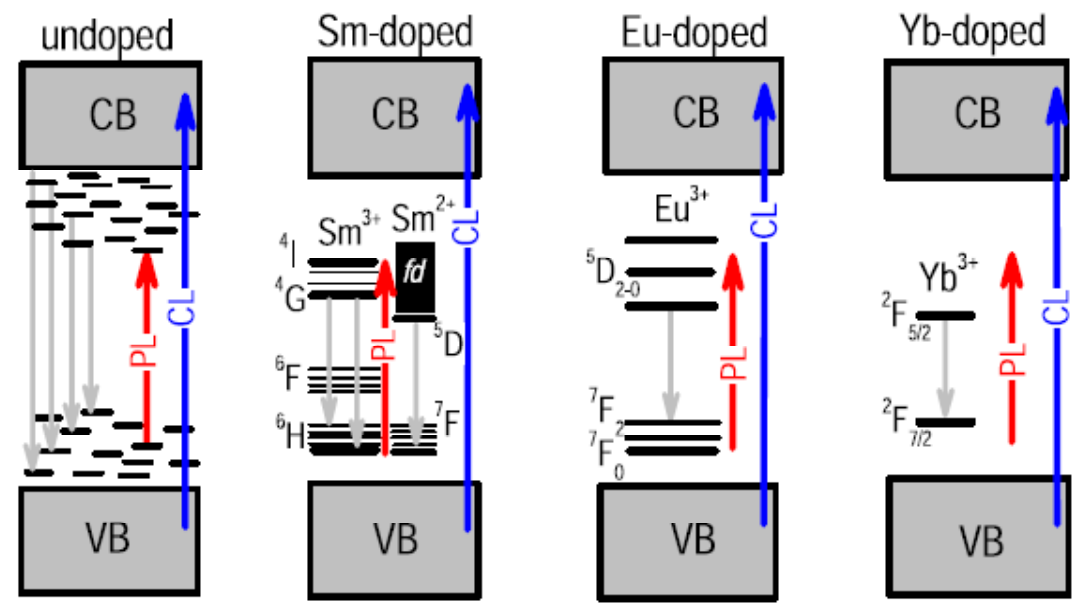

Figura 24 - Diagrama esquemático ilustrando as bandas de valência (VB) e de condução (CB) do a-AIN, seus defeitos, e alguns dos principais níveis de energia associados aos íons $\mathrm{Sm}^{3+12+}$, $\mathrm{Eu}^{3+}$, e $\mathrm{Yb}^{3+}$. Os mecanismos de excitação dos filmes de a-AlN estão indicados por PL (fótons de $488.0 \mathrm{~nm}$ ) e CL (elétrons de $20 \mathrm{keV}$ ). Os diagramas são apenas ilustrativos e não se encontram em escala.

\section{C - Filmes de a-GeN}

Filmes de a-GeN representam uma alternativa interessante para o estudo do sistema semicondutor+RE ${ }^{3+}$. Além de possuírem alguma compatibilidade com a tecnologia do silício, da mesma forma que 0 a-SiN, apresentam bandgap óptico dependente da concentração de nitrogênio com valores entre 1 e 2.5 eV [85]. Como resultado, podem ser excitados com radiação laser visível, bem como apresentar emissão devida aos íons RE ${ }^{3+}$ nas regiões do visível e infra-vermelho próximo. Comparado ao a-SiN e a-AlN, o sistema a-GeN foi bem menos estudado no LFF. Independente disto, resultados muito interessantes e completamente originais foram obtidos.

Um dos primeiros trabalhos realizados consistiu no preparo de filmes de a-GeN não-dopado, e dopado com os íons $\mathrm{Pr}^{3+}, \mathrm{Sm}^{3+}, \mathrm{Ho}^{3+}$, e $\mathrm{Er}^{3+}$. Os filmes conforme depositados apresentavam um bandgap óptico de $\sim 2$ eV e não foi possível verificar qualquer emissão luminosa dos mesmos. Desta forma, a ativação dos íons $\mathrm{RE}^{3+}$ foi feita com radiação laser, em contraste com os tradicionais tratamentos térmicos cumulativos adotados no a$\mathrm{Si}: \mathrm{H}, \mathrm{a}-\mathrm{SiN}$, e a-AlN. Os resultados deste estudo foram apresentados no 20th International Conference on Amorphous and Microcrystalline Semiconductors (Campos do Jordão- Brasil) e publicados em uma edição especial do Journal of Non-Crystalline Solids [86] - ver quadro a seguir. A Figura 25 ilustra alguns dos resultados obtidos neste trabalho. 


\section{Photoluminescence of a-GeN alloys doped with different rare-earth ions}

C.T.M. Ribeiro and A.R. Zanatta, Journal of Non-Crystalline Solids 338-340, 469 (2004)

Abstract - Amorphous (a-) GeN alloys independently doped with $\mathrm{Pr}, \mathrm{Sm}, \mathrm{Ho}$, and $\mathrm{Er}$ rare-earth (RE) elements were prepared by cosputtering a $\mathrm{Ge}+\mathrm{RE}$ target in an atmosphere of pure nitrogen. Room-temperature photoluminescence experiments indicate relatively strong visible light emission characteristic of each $\mathrm{RE}^{3+}$ ion that was obtained after laser annealing the surface of the films by means of an optical microscope and $488.0 \mathrm{~nm}$ photons. Typically, the irradiation exposures were $20 \mathrm{~s}$ long with an average power density of $\sim 2 \mathrm{~mW} \mu \mathrm{m}^{-2}$. Laser anneal induces the crystallization of the irradiated areas, as confirmed by Raman spectroscopy, and activates the RE-related photoluminescence. According to the present experimental results, RE-related light emission originates mostly from the surface of the a-GeN films and is tentatively attributed to a reduction in the density of defects and/or to the presence of $\mathrm{Ge}$ crystallites. The potential of these compounds in applications such as (micro-)devices will also be outlined.

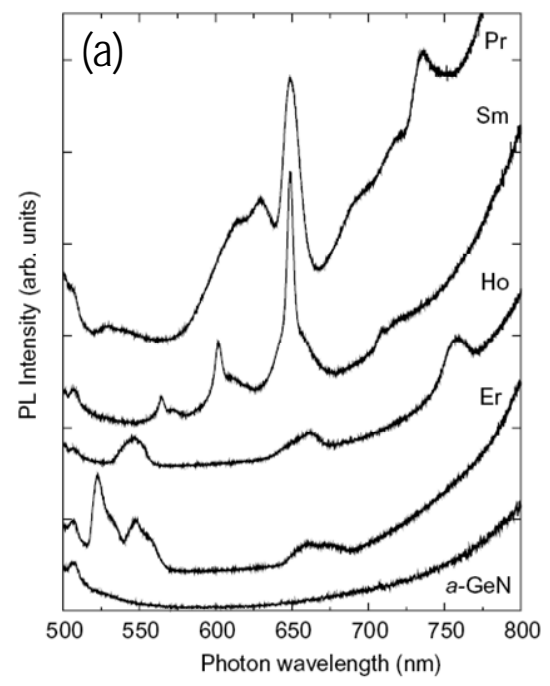

(b)

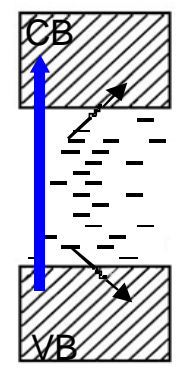

(c)

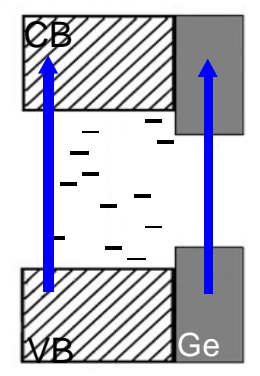

(d)

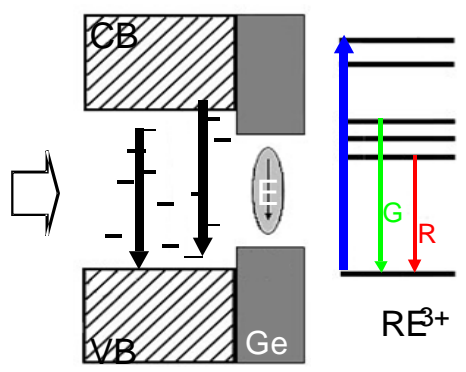

Figura 25 - (a) Espectros de foto-luminescência (excitação $488.0 \mathrm{~nm}$, temperatura ambiente) de filmes de a-GeN, não-dopado e dopado com Er, Ho, Sm, e Pr. Diagramas esquemáticos dos níveis de energia associados: (b) filme de a-GeN conforme depositado; (c) filme de a-GeN após tratamento com radiação laser, com redução no número de estados de defeito e formação de cristalitos de $\mathrm{Ge}$; (d) processo de recombinação no $\mathrm{GeN}$ e no íon $\mathrm{RE}^{3+}$. Os diagramas são apenas ilustrativos e não se encontram em escala.

Na Figura 25 temos representados os espectros de foto-luminescência, à temperatura ambiente, dos filmes de a-GeN após tratamento com radiação laser. Os espectros deixam evidentes os sinais devidos aos íons RE ${ }^{3+}$ bem como a presença de uma forte contribuição para comprimentos de onda maiores que $\sim 700 \mathrm{~nm}$.

$\mathrm{Na}$ realidade, no caso do a-GeN, a atividade óptica dos íons $\mathrm{RE}^{3+}$ está diretamente associada à cristalização dos filmes e pode ser discutida em termos de (ao menos) dois mecanismos, ou à combinação destes [Figura 25(b)-(d)]: (a) Redução de defeitos - com base nesta hipótese, o número de centros de recombinação não-radiativos é sensivelmente reduzido em decorrência do ordenamento das ligações $\mathrm{Ge}-\mathrm{Ge}$ (cristalização). Como resultado, os íns $\mathrm{RE}^{3+}$ podem ser excitados (de forma quase-ressonante ou por intermédio da matriz) e recombinarem dando origem ao sinal de PL. (b) Presença de cristalitos de Ge - neste caso, e devido à presença de micro- ou nano-cristais de Ge, o sinal de PL é função de um aumento na absorção de fótons com $488.0 \mathrm{~nm}$. Já que mais fótons são absorvidos, aumenta a probabilidade de haver transferência de energia aos íons $\mathrm{RE}^{3+}$. Da mesma forma, éxcitons associados à presença dos cristalitos de $\mathrm{Ge}$ podem transferir energia aos íons $\mathrm{RE}^{3+}$ vizinhos, dando início ao processo de recombinação radiativa. Ambas 
as hipóteses foram testadas mediante a realização de medidas de PL em função da temperatura e da potência indicando que são consistentes. Uma resposta definitiva, no entanto, requer a análise dos filmes com técnicas capazes de avaliar a estrutura local dos íons $\mathrm{RE}^{3+}$, tais como TEM (transmission electron microscopy) ou EXAFS (extended x-ray absorption fine structure), por exemplo.

Um estudo completo, detalhando o processo de cristalização mediante radiação laser (potência e tempo de limiar de cristalização, características dos cristalitos de Ge, etc.) também foi publicado [87] - ver quadro a seguir. Em especial, neste trabalho foi abordada a geração de padrões luminescentes microscópicos baseados em filmes de a-GeN+RE ${ }^{3+}$. A metodologia apresentada é totalmente compatível com outros sistemas semicondutor $+R E^{3+}$, desde que as fontes de radiação laser sejam suficientes para induzir a sua cristalização seletiva. Além disto, apresenta as seguintes grandes vantagens: (a) não requer condições especiais tais como vácuo, substratos especiais, ou altas temperaturas; (b) possibilita a geração de padrões com resolução espacial da ordem de $~ 500 \mathrm{~nm}$, sem qualquer processo litográfico; (c) permite a confecção de dispositivos de dimensões microscópicas, os quais; (d) em função das características dos íons $\mathrm{RE}^{3+}$, não necessitam de qualquer filtragem espectral.

\section{Laser-induced generation of micrometer-sized luminescent patterns on rare-earth-doped amorphous films}

A.R. Zanatta and C.T.M. Ribeiro, Journal of Applied Physics 96, 5977 (2004)

Abstract - Room-temperature photoluminescence has been achieved from rare-earth-doped amorphous (a-) GeN films. The samples were prepared by the radio-frequency-sputtering method, and light emission from the rare-earth (RE) centers was obtained after irradiating the films with a highly focused laser beam. As a result of this laser annealing procedure, almost circular holes with approximately $1 \mu \mathrm{m}$ diameter were produced on the surface of the a-GeN films. The area nearby these holes correspond to crystalline $\mathrm{Ge}$ and coincide with the regions, where relatively strong RE-related luminescence takes place. These laser-annealed areas can be easily and conveniently managed in order to generate different microscopic luminescent patterns. Depending on the RE ion employed, visible and near-infrared light emission were obtained from the patterns so produced. The development of these micrometer-sized luminescent centers, as well as their probable mechanisms of excitation-recombination, will be presented and discussed. The importance of the current experimental results to future technological applications such as microdevices, for example, will also be outlined.

O trabalho apresentou, também, imagens de foto-luminescência obtidas à temperatura ambiente deixando evidentes a atividade óptica dos íons $\mathrm{RE}^{3+}$ (nas regiões do VIS e NIR) e a alta resolução espacial que pode ser conseguida com este tipo de metodologia (Figura 26).

Muito tempo depois, o estudo do sistema a-GeN+RE ${ }^{3+}$ foi retomado para avaliar o efeito de tratamentos térmicos convencionais sobre suas propriedades ópticas e eletrônicas. Neste caso, tendo-se em conta que as dimensões alteradas com o tratamento são consideravelmente maiores, também foi possível determinar os valores de bandgap óptico das amostras. Muito deste trabalho encontram-se ainda em fase de desenvolvimento-análise, mas já é possível afirmar que o sistema a-GeN+RE ${ }^{3+}$, quando tratado termicamente, apresenta um comportamento muito semelhante àquele verificado no a-SiN. 
(a)

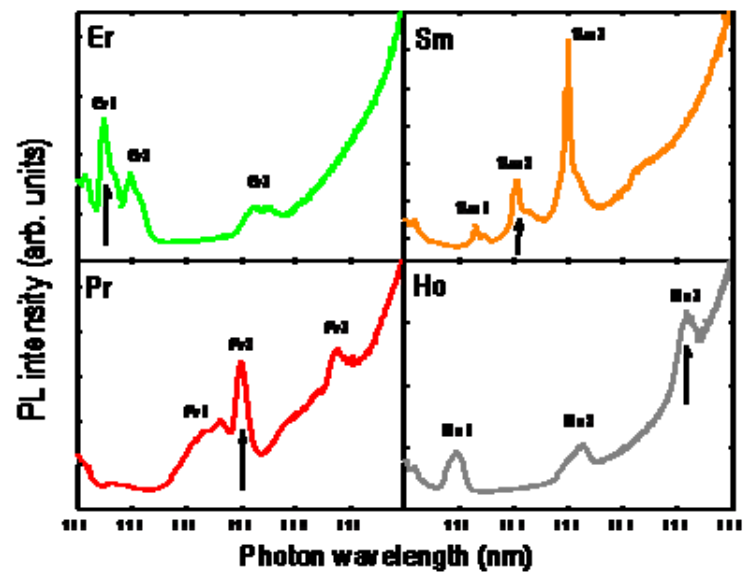

(b)

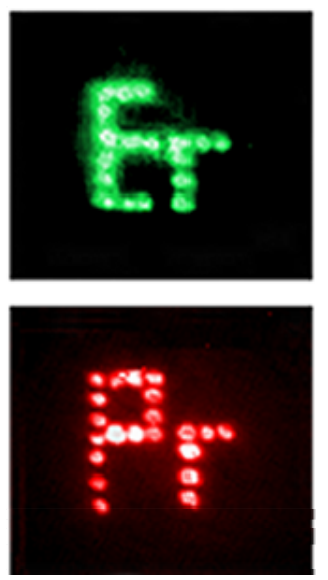

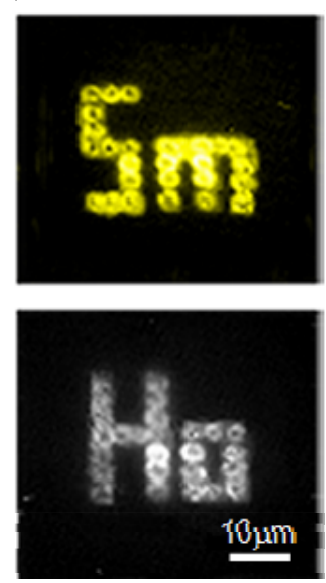

Figura 26 - (a) Espectros de foto-luminescência de filmes de a-GeN dopados com Er, Ho, Sm, e Pr após tratamento com radiação laser. (b) Imagens de foto-luminescência obtidas a partir da geração de padrões microscópicos luminescentes dos filmes apresentados em (a). Todos os resultados foram obtidos à temperatura ambiente mediante excitação com fótons de $488.0 \mathrm{~nm}$.

\section{D - Filmes de a-BeN e de a-ZnO}

Outros dois materiais que também foram estudados, ainda que com muito menos detalhe, referem-se a filmes de nitreto de berílio amorfo (a-BeN) e óxido de zinco amorfo (a-ZnO) dopados com Sm. Estes materiais foram preparados e investigados durante um estágio de curta duração na Ohio University (EUA) e apresentaram algumas características interessantes. No caso do a-BeN+Sm, não há claras evidências acerca da presença de íons $\mathrm{Sm}^{2+}$ e apenas os triplamente ionizados contribuíram com os sinais de PL e de CL. Embora realizada de forma quase-ressonante (fótons de $532.0 \mathrm{~nm}$ coincidentes com o nível ${ }^{4} \mathrm{~F}_{7 / 2}$ ), a excitação dos íons Sm ${ }^{3+}$ por fótons é muito menos eficiente quando comparada com a excitação por elétrons. Muito provavelmente, isto deve-se à baixa qualidade do material investigado (presença de defeitos estruturais, inomogeneidade, etc.) e requer um processo de otimização do a-BeN não-dopado antes de qualquer conclusão. Os resultados de $\mathrm{CL}$, no entanto, chamaram a atenção pela sua eficiência, e foram objeto de um artigo publicado em 2007 [88] - ver quadro a seguir e Figura 27(a).

\section{Amorphous BeN as a new solid host for rare-earth-related luminescent materials}

\section{A.R. Zanatta, H.H. Richardson, and M.E. Kordesch, physica status solidi (RRL) 1, 153 (2007)}

Abstract - Beryllium-nitride (BeN) thin films were prepared by sputtering a Be target in an atmosphere of pure nitrogen. The films were doped with samarium simply by placing a piece of Sm metal on the surface of the Be target. Under these deposition conditions the films present an amorphous structure and an optical bandgap of approx. $4 \mathrm{eV}$. They also exhibit visible light emission due to $\mathrm{Sm}^{3+}$ ions as a result of either photon or electron excitation. The present experimental results show that amorphous BeN films are suitable, and efficient, III-nitride hosts for rare-earth doping purposes.

Os filmes de a-ZnO também não foram investigados de maneira sistemática, mas os seus resultados foram surpreendentes na medida em que os filmes dopados com Sm passavam a apresentam sinais de CL, visíveis a olho nu, com cores que dependiam da temperatura de tratamento térmico [Figura 27(b)]. Neste caso, a matriz do ZnO experimenta transformações estruturais em decorrência dos tratamentos térmicos, e passa a 
luminescer. Quando excitados por elétrons energéticos (10 keV) a emissão associada aos íons $\mathrm{Sm}^{3+}$ e à matriz do ZnO passam a se somar dando origem a um padrão de luminescência combinado: vermelho após tratamento a $500{ }^{\circ} \mathrm{C}$ (apenas íons $\mathrm{Sm}^{3+}$ ); laranja após tratamento a $750{ }^{\circ} \mathrm{C}$ (íons $\mathrm{Sm}^{3+}$ combinados à emissão do ZnO); e verde após tratamento a $1000{ }^{\circ} \mathrm{C}$ (basicamente a matriz de ZnO). Estes resultados sugerem a possibilidade de se gerar radiação sintonizável a partir do sistema $\mathrm{ZnO}+\mathrm{Sm}^{3+}$ e/ou de obter radiação branca.

De qualquer forma, tanto os filmes de a-BeN quanto os de a-ZnO necessitam de uma investigação mais detalhada acerca de suas propriedades.

(a)

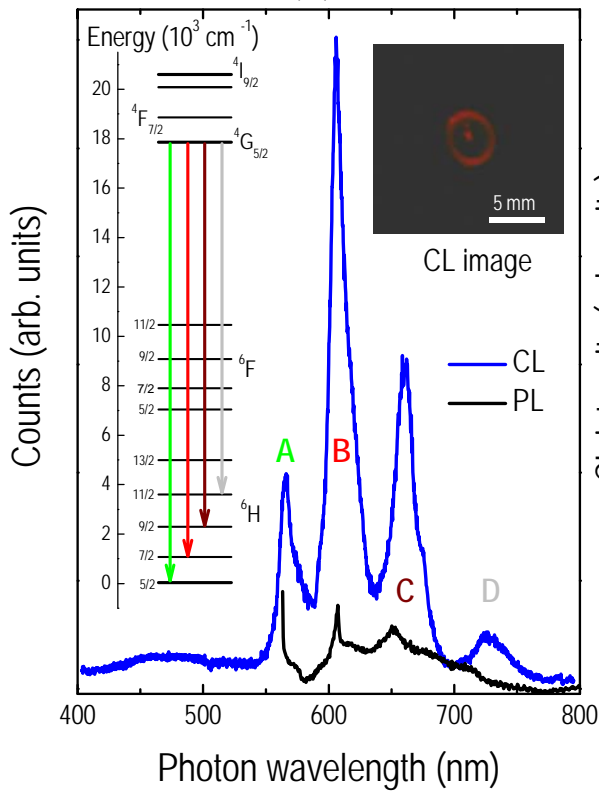

(b)

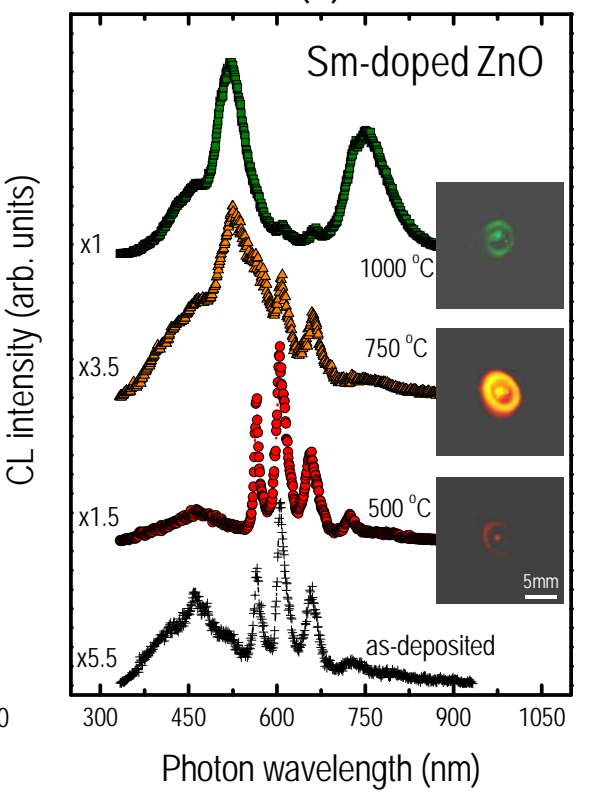

Figura 27 - (a) Espectros de foto- (excitação em $532.0 \mathrm{~nm}$ ) e catodo-luminescência (excitação em $10 \mathrm{keV}$ ) de um filme de a-BeN dopado com Sm. Em detalhe na figura encontram-se os níveis de energia do íon $\mathrm{Sm}^{3+}$ e uma foto com o sinal de CL. (b) Espectros de catodo-luminescência (excitação em $10 \mathrm{keV}$ ) obtidas a partir de um filme de a-ZnO dopado com Sm. A figura apresenta, ainda, 0 efeito de diferentes temperaturas sobre 0 sinal de $\mathrm{CL}$, com algumas fotos correspondentes. Todos os resultados foram obtidos à temperatura ambiente. 


\section{Considerações Finais}

Dentro do cenário internacional, e mesmo após mais de 30 anos de pesquisas, o sistema semicondutor+RE ${ }^{3+}$ ainda desperta grande interesse e apresenta um enorme potencial para aplicações. A considerar pela alternância de motivações sócio-econômico-tecnológicas, há que se dizer que o tema passou por várias transformações: de materiais baseados exclusivamente em silício (visando aplicações na área de telecomunicações), para compostos das mais diferentes espécies (para utilização como displays e/ou fontes de radiação (aser). Independente do material considerado e/ou do tipo de aplicação desejada, no entanto, não há como negar os avanços científicos na área, bem como os conhecimentos gerados.

No estágio atual, sabe-se que os sistemas c-Si+E ${ }^{3+}$ e a-Si:H+Er ${ }^{3+}$ são extremamente ineficientes na geração de radiação luminosa. Por outro lado, os processos de excitação-recombinação presentes nestes sistemas são tão bem conhecidos que permitiram a confecção de detectores (totalmente compatíveis com a atual tecnologia de telecomunicações) onde se faz uso do mecanismo de transferência de energia por back transfer $[8,89]$. Este é apenas um exemplo (dentre outros tantos) onde, desde que convenientemente explorada, alguma propriedade inerente de um sistema pode render bons resultados. De qualquer forma, a eficiência de emissão de LED's (light-emitting diodes) preparados a partir do sistema semicondutor+RE ${ }^{3+}$, ainda é muito inferior quando comparada àquela apresentada por dispositivos baseados em compostos do tipo III-V $[8,31,32]$. Neste sentido, boa parte dos trabalhos futuros deve se concentrar no aumento da eficiência no sistema semicondutor $+\mathrm{RE}^{3+}$. Dentre algumas das alternativas mais promissoras para se alcançar este propósito destacam-se: (a) processo de sensitização - quer seja mediante efeitos de confinamento quântico (nanopartículas de silício, por exemplo), partículas metálicas, ou combinações de íons RE ${ }^{3+}$; e (b) utilização de microcavidades ópticas. Enquanto no primeiro caso a atenção está voltada para uma efetiva excitação dos íons $\mathrm{RE}^{3+}$; no segundo, o objetivo reside na amplificação do sinal. Compostos de bandgap óptico grande também devem fazer parte deste cenário sob o pretexto de, além de serem ligeiramente mais eficientes, se prestarem à confecção de dispositivos na região de radiação visível.

Tendo por base as informações apresentadas neste Capítulo fica claro que, muito do trabalho realizado no LFF, teve por objetivo principal a investigação do sistema silício+RE ${ }^{3+}$. Isto vai de encontro à proposta de desenvolvimento de dispositivos híbridos (opto-eletrônicos) integrados, totalmente compatíveis com a tecnologia do silício - também chamada de fotônica do silício. Dentro deste contexto vale destacar os trabalhos realizados com os seguintes sistemas: (1) silício amorfo hidrogenado dopado com $\mathrm{Er}^{3+}\left(\mathrm{a}-\mathrm{Si}: \mathrm{H}+\mathrm{Er}^{3+}\right.$ ) e codopado com $\mathrm{Yb}^{3+}$ (a-Si:H+Er $\left.{ }^{3+}+\mathrm{Yb}^{3+}\right)$; e (2) nitreto de silício com diversos íons terra-rara (a-SiN+RE${ }^{3+}$ ). Em ambos os casos, foram realizados estudos sistemáticos que tiveram por objetivo determinar a influência de diferentes variáveis sobre a ativação óptica e a eficiência de emissão dos íons $\mathrm{E}^{3+}$. Desta forma, o papel de impurezas tais como nitrogênio e oxigênio; a concentração ideal de íons $\mathrm{Er}^{3+}$ e do conjunto $\mathrm{Er}^{3+} \mathrm{Yb}^{3+}$; e 0 efeito da temperatura de tratamento térmico foram exploradas em detalhe. Para o sistema a-SiN+RE ${ }^{3+}$, em especial, foram considerados ainda: questões associadas à extinção do sinal de foto-luminescência (temperatureinduced PL quenching); diferentes íons $\mathrm{RE}^{3+}$ (e RE ${ }^{2+}$ ) e combinações destes; os mecanismos de excitaçãorecombinação dos íons RE; processos decorrentes da excitação das amostras quando excitadas por elétrons (catodo-luminescência); e a emissão de radiação devida aos íons RE nas regiões do UV-VIS-NIR. 
Em todos os casos, é importante destacar que as investigações fizeram uso das mais diferentes técnicas de caracterização experimental.

Com 0 propósito de obter informações adicionais, o conjunto de estudos realizados contemplou não apenas o sistema silício+RE ${ }^{3+}$, mas outros compostos ricos em nitrogênio (a-GaAsN, a-AIN, a-GeN, e a-BeN) ou oxigênio (a-ZnO) também foram considerados em relativo detalhe.

Ainda que limitado apenas à emissão na região do infra-vermelho próximo ( $1540 \mathrm{~nm})$, o sistema aGaAsN+Er ${ }^{3+}$ envolveu o estudo de filmes de a-GaAsN com diferentes concentrações de nitrogênio e, portanto, diferentes características ópticas-eletrônicas. Mais precisamente, o estudo deste sistema permitiu avaliar a influência do bandgap óptico das amostras sobre a intensidade do sinal de PL devida ao íon $\mathrm{Er}^{3+}$.

Muitos dos filmes de AIN considerados apresentaram estrutura amorfa e uma composição muito próxima à estequiométrica ( $50 \% \mathrm{Al}+50 \% \mathrm{~N}$ ). Com efeito, os filmes de a-AlN prestaram-se à análise dos mecanismos de excitação-recombinação de vários íons $\mathrm{RE}^{3+}$ bem como suas emissões nas regiões do visível e infra-vermelho próximo. Em conjunto com os resultados obtidos no caso do a-SiN+RE ${ }^{3+}$ deram claras evidências acerca do processo de excitação quase-ressonante de alguns íons $\mathrm{RE}^{3+}$.

Um procedimento análogo (utilização de diferentes íons $\mathrm{RE}^{3+}$ e investigação dos mecanismos de excitação- recombinação) foi adotado no estudo de filmes de a-GeN. Neste caso, no entanto, os íons RE ${ }^{3+}$ passaram a apresentar emissão luminosa apenas após a sua cristalização (seletiva) com radiação laser. Além de agregar novas informações sobre os mecanismos de excitação dos íons $\mathrm{RE}^{3+}$, a metodologia desenvolvida durante este trabalho é potencialmente interessante para a confecção de dispositivos luminescentes com dimensões reduzidas - sem necessidade de condições especiais tais como processos litográficos, por exemplo.

Por fim, e ainda que estudados com muito menos detalhe, a introdução de $\mathrm{Sm}$ em filmes de a-BeN e aZnO provou que estas matrizes são interessantes para o estudo-desenvolvimento de novos materiais luminescentes. A dependência do sinal de $\mathrm{CL}$ com a temperatura de tratamento nos filmes de $\mathrm{ZnO}+\mathrm{Sm}$, em particular, sugere que este sistema possa ser aplicado para a construção de dispositivos eletro-luminescentes (EL) sintonizáveis ou para a geração de luz branca, por exemplo.

Para o futuro, pretendemos avançar ainda mais na investigação dos sistemas $\mathrm{SiN}+\mathrm{RE}^{3+}$ e $\mathrm{AIN}+\mathrm{RE}^{3+}$, quer seja mediante a utilização destes em micro-cavidades ópticas ou mediante a confeç̧ão dispositivos EL simples. Em ambos os casos, deve-se proceder à otimização das propriedades dos materiais (eliminando a necessidade de tratamentos térmicos e/ou reduzindo a temperatura de extinção da luminescência), e estabelecendo condições para a produção das micro-cavidades e evaporação de contatos, por exemplo. 


\section{Referências}

1 T. P. Pearsall, in Photonics Essentials (McGraw-Hill, NY 2003).

2 B. E. A. Saleh and M. C. Teich, in Fundamentals of Photonics (John Wiley \& Sons, New Jersey 2007).

3 R. G. Hunsperger, in Integrated Optics: Theory and Technology (Springer, NY 2009).

${ }^{4}$ C. Yeh, in Applied Photonics (Academic Press, San Diego 1994).

5 Veja, por exemplo, J.I. Pankove, in Optical Processes in Semiconductors (Dover Publications, NY 1971).

${ }^{6}$ L. Brus, J. Phys. Chem. 98, 3575 (1994).

7 R. A. Street, in Hydrogenated Amorphous Silicon (Cambridge University Press, Oxford 1991).

8 L. Pavesi and D. J. Lockwood (Eds), in Silicon Photonics, Topics in Applied Physics 94 (Springer, Berlin 2004).

${ }^{9}$ R. Tsu, in Superlattice to Nanoelectronics (Elsevier B.V., The Netherlands 2005).

10 A.J. Kenyon, Prog. Quant. Electron. 26, 225 (2002).

11 A. Polman, J. Appl. Phys, 82, 1 (1997).

12 R.J. Hoss and E.A. Lacy, in Fiber Optics (Prentice-Hall International, New Jersey 1993).

13 A.P. Jones, F. Wall, and C.T. Williams (Eds.), in Rare-Earth Minerals: Chemistry, Origin, and Ore Deposits (Chapman \& Hall, London 1996).

$14 \mathrm{~T}$. Moeller, in The Chemistry of the Lantanides (Pergamon, London 1975).

15 B. Henderson and G.F. Imbush, in Optical Spectroscopy of Inorganic Solids (Clarendon, Oxford 1989).

16 G.H. Dieke, in Spectra and Energy Levels of Rare-Earth lons in Crystals (Interscience, NY 1968).

17 J.A. Duffy, in Bonding, Energy Levels and Bands in Inorganic Solids (Longman, Essex 1990).

18 Ver, por exemplo, B. di Bartolo (Ed.), in Energy Transfer Processes in Condensed Matter (Plenum Press, NY 1984).

19 A.J. Steckl, J.Heikenfeld, M. Garter, R. Birkhahn, and D.S. Lee, Comp. Semicond. 6, 48 (2000).

20 B.R. Judd, Phys. Rev. 127, 750 (1962).

21 G.S. Ofelt, J. Chem. Phys. 37, 511 (1962).

22 L. A. Riseberg and M. J. Weber, in Progress in Optics, Vol. XIV (North-Holland, Amsterdam, 1976).

23 W. Miniscalco, IEEE J. Lightwave Technol. 9, 234 (1991).

24 R. Reisfeld and C.K. Jorgensen, in Lasers and Excited States of Rare-Earths (Springer-Verlag, Berlin 1977).

25 Ver, por exemplo, C.T.M. Ribeiro, A.R. Zanatta, L.A.O. Nunes, Y. Messaddeq, and M.A. Aegerter, J. Appl. Phys. 83, 2256 (1998), e referências internas.

26 T. Foerster, Annales de Physique 2, 55 (1948).

27 D.L. Dexter, J. Chem. Phys. 21, 836 (1953).

${ }^{28}$ Ver, por exemplo, E. Desurveir, in Erbium-doped Amplifiers: Principles and Applications (Wiley, NY 1994).

29 J.G. Solé, L.E. Bausá, and D. Jaque, in An Introduction to the Optical Spectroscopy of Inorganic Solids (John Wiley \& Sons, Chichester 2005).

30 Vários autores, in Mater. Sci. Forum 258-263 (1997).

31 Vários autores, in MRS Bulletin 24 (1999).

32 Ver A.J. Steckl, J.H. Park, and J.M. Zavada, Materials Today 10, 20 (2007), e referências internas.

${ }^{33}$ H. Ennen, J. Schneider, G. Pomrenke, and A. Axmann, Appl. Phys. Lett. 43, 943 (1983). 
${ }^{34}$ H. Ennen, G. Pomrenke, A. Axmann, K. Eisele, W. Haydl, and J. Schneider, Appl. Phys. Lett. 46, 381 (1985).

${ }^{35}$ A.J. Kenyon, Semicond. Sci. Technol. 20, R65 (2005).

36 Vários autores, in Materials Today 8 (2005).

37 T. Oestereich, C. Swiatkowski, and I. Broser, Appl. Phys. Lett. 56, 446 (1990).

${ }^{38}$ R.A. Street, in Hydrogenated Amorphous Silicon (Cambridge University Press, Oxford 1991).

39 D.L. Adler, D.C. Jacobson, D.J. Eaglesham, M.A. Marcus, J.L. Benton, J.M. Poate, and P.H. Citrin, Appl. Phys. Lett. 61, 2181 (1992).

${ }^{40}$ C. Piamonteze, A.C. Iniguez, L.R. Tessler, M.C.M. Alves, and H. Tolentino, Phys. Rev. Lett. 81, 4652 (1998).

41 O.B. Gusev, A.N. Kuznetsov, E.I. Terukov, M.S. Bresler, V.K. Kudoyarova, I.N. Yassievich, B.P. Zakharchenya, and W. Fuhs, Appl. Phys. Lett. 70, 240 (1997).

${ }^{42}$ A.G. Cullis, L.T. Canham, and P.D.J. Calcott, J. Appl. Phys. 82, 909 (1997).

${ }^{43}$ A.M. Vredenberg, N.E.J. Hunt, E.F. Schubert, D.C. Jacobson, J.M. Poate, and G.J. Zydzik, Phys. Rev. Lett. 71, 517 (1993).

${ }^{44}$ A.A. Dukin, N.A. Feoktistov, V.G. Golubev, A.V. Medvedev, A.B. Pevtsov, and A.V. Sel'kin, Appl. Phys. Lett. 77, 3009 (2000).

${ }^{45}$ A. Chiasera, R. Bell, S.N.B. Bhaktha, A. Chiappini, M. Ferrari, Y. Jestin, E. Moser, G.C. Righini, and C. Tosello, Appl. Phys. Lett. 89, 171910 (2006).

${ }^{46}$ A. Serpenguzel and S. Tanriseven, Appl. Phys. Lett. 78, 1388 (2001).

47 Y. Li and R.M. Almeida, J. Phys. D: Appl. Phys. 43, 455101 (2010).

${ }^{48}$ A.R. Zanatta and L.A.O. Nunes, Appl. Phys. Lett. 72, 3127 (1998).

${ }^{49}$ A.J. Steckl and R. Birkhahn, Appl. Phys. Lett. 73, 1700 (1998).

${ }^{50}$ E. Steveler, H. Rinnert, X. Devaux, M. Dossot, and M. Vergnat, Appl. Phys. Lett. 97, 221902 (2010).

${ }^{51}$ A.R. Zanatta, L.A.O. Nunes, and L.R. Tessler, Appl. Phys. Lett. 70, 511 (1997).

${ }^{52}$ A.R. Zanatta and L.A.O. Nunes, Appl. Phys. Lett. 71, 3679 (1997).

${ }^{53}$ A.R. Zanatta and L.A.O. Nunes, J. Non-Crystal. Sol. 227-230, 389 (1998).

${ }^{54}$ L.R. Tessler and A.R. Zanatta, J. Non-Crystal. Sol. 227-230, 399 (1998).

${ }^{55}$ A.R. Zanatta and F.L. Freire Jr., Phys. Rev. B 62, 2016 (2000).

56 V.I. de Oliveira, in "Propriedades ópticas de filmes finos de silício amorfo hidrogenado dopados com érbio", Dissertação (Mestrado em Física Aplicada) 69 pp., Instituto de Física de São Carlos - Universidade de São Paulo - 2005.

57 V.I. de Oliveira, F.L. Freire Jr., and A.R. Zanatta, J. Phys: Condens. Matter 18, 7709 (2006).

${ }^{58}$ P.N. Favennec, H.L. Haridon, M. Salvi, D. Moutonnet, and Y.L. Guillou, Electron. Lett. 25, 718 (1989).

${ }^{59}$ A.R. Zanatta, Appl. Phys. Lett. 82, 1395 (2003).

${ }^{60}$ A.R. Zanatta, M.J.V. Bell, and L.A.O. Nunes, Phys. Rev. B 59, 10091 (1999).

${ }^{61}$ M.J.V. Bell, L.A.O. Nunes, and A.R. Zanatta, J. Appl. Phys. 86, 338 (1999).

62 S. Yerci, R. Li, and L. dal Negro, Appl. Phys. Lett. 97, 081109 (2010).

${ }^{63}$ A.R. Zanatta, C.T.M. Ribeiro, and U. Jahn, Appl. Phys. Lett. 79, 488 (2001).

64 B.G. Yacobi and D.B. Holt, in Cathodoluminescence Microscopy of Inorganic Solids (Plenum, New York 1990).

${ }^{65}$ K. Kanaya and S. Okayama, J. Phys. D 5, 43 (1972). 
${ }^{66}$ A.G. Cullis, L.T. Canham, G.M. Williams, P.W. Smith, and O.D. Dosser, J. Appl. Phys. 75, 493 (1994).

${ }^{67}$ A.R. Zanatta, C.T.M. Ribeiro, and U. Jahn, J. Non-Cryst. Sol. 338-340, 473 (2004).

${ }^{68}$ C.T.M. Ribeiro, M. Siu Li, and A.R. Zanatta, J. Appl. Phys. 96, 1058 (2004).

69 A.R. Zanatta, C.T.M. Ribeiro, and F. Alvarez, J. Appl. Phys. 93, 1948 (2003).

70 C.T.M. Ribeiro and A.R. Zanatta, não publicado.

71 M.S. Sercheli, C. Rettori, and A.R. Zanatta, Sol. St. Commun. 128, 47 (2003).

72 M.S. Sercheli, C. Rettori, and A.R. Zanatta, Phys. Rev. B 68, 174418 (2003).

${ }^{73}$ A.R. Zanatta, A. Khan, and M.E. Kordesch, J. Phys.: Condens. Matter 19, 436230 (2007).

${ }^{74}$ A.R. Zanatta, Appl. Phys. Lett. 75, 3279 (1999).

${ }^{75}$ A.R. Zanatta, J. Non-Cryst. Sol. 266-269, 854 (2000).

${ }^{76}$ A.R. Zanatta, P. Hammer, and F. Alvarez, Appl. Phys. Lett. 76, 2211 (2000).

${ }_{77}$ A.R. Zanatta, C.T.M. Ribeiro, and F.L. Freire Jr., J. Appl. Phys. 90, 2321 (2001).

78 C.T.M. Ribeiro, F. Alvarez, and A.R. Zanatta, Appl. Phys. Lett. 81, 1005 (2002).

${ }^{79}$ C.T.M. Ribeiro, A.R. Zanatta, and F. Alvarez, J. Non-Cryst. Sol. 299-302, 323 (2002).

80 A.R. Zanatta, C.T.M. Ribeiro, and F. Alvarez, J. Appl. Phys. 92, 6349 (2002).

${ }^{81}$ C.T.M. Ribeiro, F. Alvarez, and A.R. Zanatta, Adv. Mater. 14, 1154 (2002).

82 A.R. Zanatta, C.T.M. Ribeiro, and U. Jahn, J. Appl. Phys. 98, 093514 (2005).

${ }^{83}$ R. Weingaertner, O. Erlenbach, A. Winnacker, A. Welt, I. Brauer, H. Mendel, H.P. Strunk, C.T.M. Ribeiro, and A.R. Zanatta, Opt. Mater. 28, 790 (2006).

${ }^{84}$ A.R. Zanatta, J. Phys. D: Appl. Phys. 42, 025109 (2009).

85 I. Chambouleyron and A.R. Zanatta, J. Appl. Phys. 84, 1 (1998).

${ }^{86}$ C.T.M. Ribeiro and A.R. Zanatta, J. Non-Cryst. Sol. 338-340, 469 (2004).

${ }^{87}$ A.R. Zanatta and C.T.M. Ribeiro, J. Appl. Phys. 96, 5977 (2004).

${ }^{88}$ A.R. Zanatta, H.H. Richardson, and M.E. Kordesch, phys. stat. sol. (RRL) 1, 153 (2007).

${ }^{89}$ A.J. Kenyon, Semicond. Sci. Technol. 20, R65 (2005). 


\section{Capítulo 4}

\section{Filmes semicondutores amorfos à base de Si Conclusões \& Perspectivas}

Neste trabalho foram apresentados e discutidos os principais resultados obtidos no Laboratório de Filmes Finos tendo como motivação principal a investigação das propriedades ópticas-eletrônicas-estruturais de algumas classes de filmes finos. Mais especificamente, foram abordados aspectos relativos aos mecanismos de cristalização de filmes semicondutores amorfos (Capítulo 2), e as propriedades ópticas-eletrônicas destes quando dopados com íons terra-rara (Capítulo 3). Em ambos os casos foram considerados (em sua grande maioria) filmes à base de silício - cuja escolha deve-se às suas eventuais aplicações na moderna indústria (micro-)eletrônica.

Conforme apresentado no Capítulo 1, enquanto dispositivos (micro-)eletrônicos baseados na chamada tecnologia do silício (relativa ao elemento, seus compostos, e processos associados) são parte integrante de muitos dos recursos tecnológicos disponíveis na atualidade, não é de se esperar que esta seja eterna: apesar de eficiente e extremamente desenvolvida, dispositivos eletrônicos tendo por base a tecnologia do silício estão chegando ao seu limite. Isto é particularmente verdadeiro se levarmos em consideração questões como miniaturização, rapidez, eficiência, e consumo energético, por exemplo. Além disto, tendo-se em conta a atual demanda tecnológica, estima-se que a tecnologia do silício possa ser aplicável por, no máximo, mais 10-15 
anos. Desta forma, muitas das investigações na área de materiais tem se concentrado na busca por substitutos ao silício e/ou no desenvolvimento de novas metodologias de processamento. No estágio atual, vários são os candidatos que apresentam características de eficiência e miniaturização (e, portanto, portabilidade e baixo consumo energético) comparáveis ou, até mesmo, superiores àquelas exibidas pelo silício. Em sua grande maioria, no entanto, os custos associados são inviáveis e/ou a tecnologia necessária é ainda incipiente. Um raciocínio análogo aplica-se ao desenvolvimento de novas metodologias de processamento deixando evidente a necessidade destas serem compatíveis com a já estabelecida tecnologia do silício. Uma solução alternativa, igualmente interessante, consiste na atribuição de novas funcionalidades ao silício e seus compostos de modo a obter propriedades híbridas ópticas+eletrônicas, magnéticas+eletrônicas, por exemplo, e que vêm sendo denominadas de fotônica do silício e spintrônica do silício, respectivamente. Idealmente, tais propriedades podem ser obtidas através da inserção de impurezas específicas e/ou realçadas mediante o processamento de compostos à base do silício. Independente da metodologia a ser adotada, não resta qualquer dúvida que 0 desenvolvimento-obtenção destas características híbridas está sujeita ao estudo sistemático das propriedades do silício (e seus compostos) sob diferentes condições.

Este é, justamente, o propósito de muitas das pesquisas conduzidas no Laboratório de Filmes Finos algumas das quais tendo sido consideradas na redação deste trabalho.

Estritamente ao conteúdo aqui apresentado:

Após uma breve introdução dos conceitos associados ao estado (sólido) amorfo, o Capítulo 2 expõe detalhes sobre os semicondutores amorfos: estrutura atômica, estrutura eletrônica, processos de formação, e estabilidade térmica e estrutural. Tais informações serviram de base para a discussão dos mecanismos de cristalização destes materiais - devidos à presença de espécies metálicas (MIC- metal induced crystallization) e assistidos por radiação laser (LIC- laser induced crystallization).

O Capítulo 2 segue com a apresentação comentada de alguns resultados de MIC: (a) filmes de a-Ge:H dopados com Al e tratados termicamente até $500^{\circ} \mathrm{C}$; (b) filmes de a-Si com concentrações de Ni desde o nível de dopagem até a formação de ligas-silicetos, submetidos a tratamentos até $\sim 1000{ }^{\circ} \mathrm{C}$; e (c) outras combinações onde o fenômeno de MIC pode (Ge+Mn), ou não (SiMn e SiFe), se manifestar mas, que sempre são acompanhadas pela formação de novas fases $\left(\mathrm{Mn}_{5} \mathrm{Ge}_{3}, \mathrm{MnSi}_{1.7}\right.$ e FeSi 2 ). Em praticamente todos os sistemas investigados existem evidências de que o processo de MIC dá-se a nível atômico-molecular e é altamente influenciado pelas características químicas dos metais e dos semicondutores considerados. Como característica fundamental dos trabalhos envolvendo o processo de MIC é importante salientar: (1) a investigação de filmes co-depositados (sistema semicondutor+metal homogêneo), e não sob a forma de multicamadas; (2) a realização de estudos sistemáticos no que diz respeito ao preparo, condições de tratamento, e caracterizações espectroscópicas; e (3) os tratamentos térmicos sempre foram realizados por intervalos relativamente curtos (15 min) sob condições altamente controladas.

O tema de cristalização induzida por radiação laser (LIC) considerou os seguintes sistemas: (1) filmes de a-Si:H dopado com Er ${ }^{3+}$; (2) filmes de a-Ge depositados sobre substratos de GaAs cristalino - sob a forma de cristalização homogênea e de laser structuring; e (3) filmes de a-GeN para aplicações em grades de relevo ou para a geração de padrões microscópicos luminescentes. Neste último caso, em particular, a metodologia adotada mostrou-se perfeitamente adequada para a produção de estruturas com dimensões típicas da ordem de 1-2 $\mu \mathrm{m}$, as quais podem ser de grande interesse na confecção de micro-dispositivos opto-eletrônicos. 
O Capítulo 3 teve por objetivo específico tratar da fotônica do silício a partir da utilização de filmes dopados com espécies opticamente ativas. Para tanto, o capítulo inicia-se com a apresentação do potencial tecnológico de semicondutores dopados com íons terra-rara (sistema semicondutor $+\mathrm{RE}^{3+}$ ) em aplicações na área de telecomunicações e de displays. Faz um breve resumo dos principais conceitos associados aos íons terra-rara e uma espécie de state of the art do sistema semicondutor $+\mathrm{RE}^{3+}$. Sob o pretexto de investigar-desenvolver dispositivos híbridos (opto-eletrônicos) integrados, totalmente compatíveis com a tecnologia do silício, passa à análise comentada de resultados experimentais dos seguintes compostos: (1) silício amorfo hidrogenado

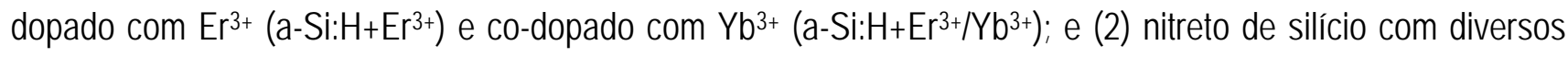
íons terra-rara (a-SiN+RE ${ }^{3+}$. Atenção especial foi dedicada ao sistema a-SiN $+\mathrm{RE}^{3+}$, cujo alto valor de bandgap óptico faz com que seja pouco influenciado pelo fenômeno de extinção do sinal de foto-luminescência (temperature-induced PL quenching). Além disto, também foram considerados em detalhe: diferentes íons RE ${ }^{3+}$ (e $\mathrm{RE}^{2+}$ ) e combinações destes; os mecanismos de excitação-recombinação dos íons RE; processos decorrentes da excitação das amostras quando excitadas por elétrons (catodo-luminescência); e a emissão de radiação devida aos íons RE nas regiões do UV-VIS-NIR. O conjunto de estudos realizados não se limitou apenas ao sistema silício+RE ${ }^{3+}$, e outros compostos ricos em nitrogênio (a-GaAsN, a-AIN, a-GeN, e a-BeN) ou oxigênio (a-ZnO) também foram considerados, possibilitando uma compreensão detalhada dos fenômenos associados.

Ainda que relativamente extenso, todo o trabalho realizado nas áreas de cristalização de filmes semicondutores amorfos e no estudo das suas propriedades ópticas-eletrônicas está longe de se dar por encerrado. Enquanto as informações aqui contidas foram fundamentais para verificar hipóteses e avançar na compreensão destes temas, não restam dúvidas de que há ainda muito o que fazer. Neste sentido, como perpectivas de trabalhos futuros pode-se mencionar: (1) investigação dos fenômenos de MIC em filmes de a-Si, a-Ge, e a-SiGe levando em consideração diferentes metais; (2) explorar em detalhe a real influência da presença de fases secundárias (silicetos) no processo de MIC; (3) estender os estudos de cristalização para processos envolvendo a aplicação de deformações externas (PIC- pressure induced crystallization) e campos elétricos (CIC- current induced crystallization); (4) realizar o processo de LIC em atmosfera reativa para a formação de padrões microscópicos à base de nitretos ou óxidos, por exemplo; (5) investigar em detalhe 0 processo de sensitização no sistema semicondutor $+\mathrm{RE}^{3+}$ - quer seja devido a efeitos de confinamento quântico (nano-partículas de silício, por exemplo), partículas metálicas, ou combinações de íons RE ${ }^{3+}$; (6) utilização de micro-cavidades ópticas para 0 aumento da intensidade do sinal de luminescência, bem como a sua eventual utilização em algum tipo de dispositivo; (7) confecção de dispositivos eletro-luminescentes a partir do sistema semicondutor+ $\mathrm{RE}^{3+}$; etc. 